\title{
MASTE $\mathbb{R}_{\text {Report }}$
}

By

Fred A. Schooley

Susan J. Mara

David A. Mendel

Paul C. Meagher

Edward C. So

Ronald L. Dickenson

October 1979

Work Performed Under Contract No. AC01-78ET20076

SRI International

Menlo Park, California
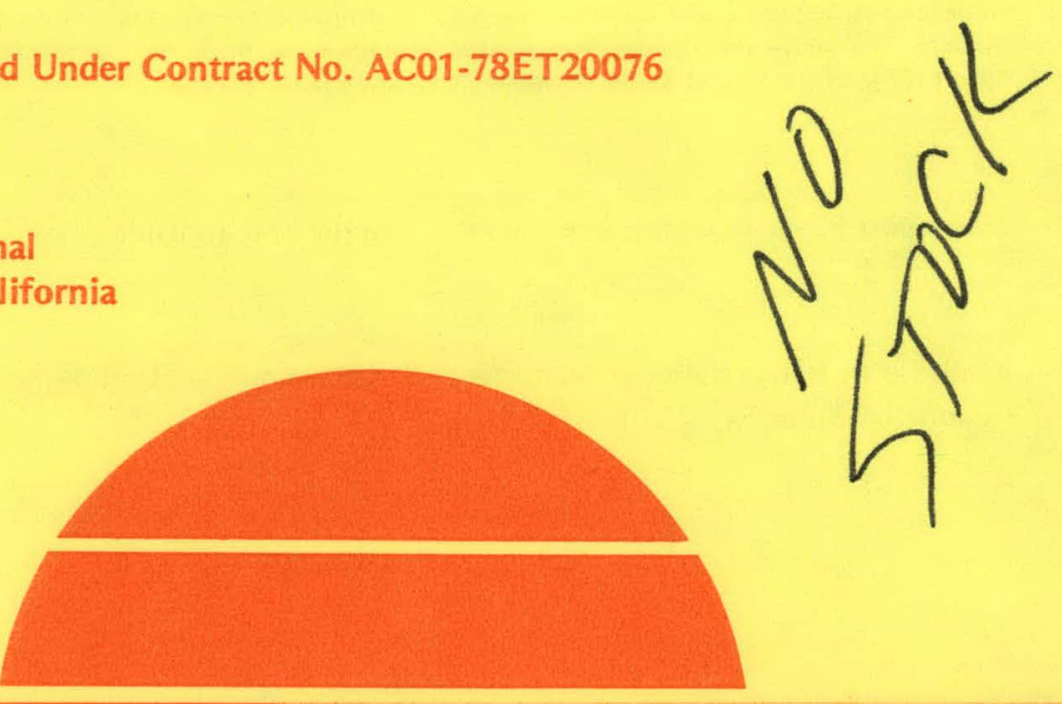

\section{U.S. Department of Energy}

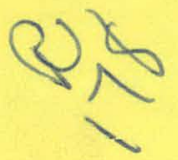

\section{Solar Energy}




\section{DISCLAIMER}

This report was prepared as an account of work sponsored by an agency of the United States Government. Neither the United States Government nor any agency Thereof, nor any of their employees, makes any warranty, express or implied, or assumes any legal liability or responsibility for the accuracy, completeness, or usefulness of any information, apparatus, product, or process disclosed, or represents that its use would not infringe privately owned rights. Reference herein to any specific commercial product, process, or service by trade name, trademark, manufacturer, or otherwise does not necessarily constitute or imply its endorsement, recommendation, or favoring by the United States Government or any agency thereof. The views and opinions of authors expressed herein do not necessarily state or reflect those of the United States Government or any agency thereof. 


\section{DISCLAIMER}

Portions of this document may be illegible in electronic image products. Images are produced from the best available original document. 


\section{DISCLAIMER}

"This book was prepared as an account of work sponsored by an agency of the United States Government. Neither the United States Government nor any agency thereof, nor any of their employees, makes any warranty, express or implied, or assumes any legal liability or responsibility for the accuracy, completeness, or usefulness of any infunmation, apparatus, product, or process disclosed, or represents that its use would not infringe privately owned rights. Reference herein to any specific commercial product, process, or service by trade name, trademark, manufacturer, or otherwise, does not necessarily constitute or imply its endorsement, recommendation, or favoring by the United States Government or any agency thereof. The views and opinions of authors expressed herein do not necessarily state or reflect those of the United States Government or any agency thereof."

This report has been reproduced directly from the best available copy.

Available from the National Technical Information Service, U. S. Department of Commerce, Springfield, Virginia 22161.

Price: Paper Copy $\$ 16.00$

Microfiche $\$ 3.50$ 


\section{WATER AND LAND AVAILABILITY FOR ENERGY FARMING}

Final Report

October 1979

Prepared by:

Fred A. Schooley, Project Leader . Susan J. Mara David A. Mendel Paul C. Meagher Edward C. So

Ronald L. Dickenson, Project Supervisor

Prepared for:

The United States Department of Energy Division of Distributed Solar Technology Biomass Energy Systems Branch Washington, D.C.

SRI International Project No. 7877 
THIS PAGE

\section{WAS INTENTIONALLY LEFT BLANK}


CONTENTS

LIST OF ILLUSTRATIONS. . . . . . . . . . . . . . . ix

LIST OF TABLES . . . . . . . . . . . . . . . . . .

GLOSSARY ....................... . . . . xiii

ABSTRACT ...................... . $x i v$

PREFACE. . . . . . . . . . . . . . . . . . $\mathrm{xv}$

I SUMMARY AND CONCLUSIONS . . . . . . . . . . . . . 1

Summary of Ranking Results. . . . . . . . . . . . 1

Water Availability Analysis . . . . . . . . . . . 2

Land Availability Analysis. . . . . . . . . . . 3

Subbasin Survey Results . . . . . . . . . . . . 6

Subbasin 1702--Northeastern Oregon and

Eastern Washington ................ 6

Subbasin 306--Southwestern Georgia . . . . . . . 6

Subbas in 304--Northern Florida and Southern

Georgia. . . . . . . . . . . . . . . . . 7

Subbasin 302--South Carolina and Western

North Carolina................. . 7

Subbasin 701--Minnesota. . . . . . . . . . . . 8

Subbasin 206--Northern Virginia and Western

Maryland ..................... 8

Subbasin 602--Northern Alabama and South

Central Tennessee. . . . . . . . . . . . 9

Subbasin 404--Eastern Michigan ........... 9

Subbasin 1101--Northern Arkansas and

Southern Missouri................ 10

Subbasin 101--Malne.............. 10

II INTRODUCTION. . . . . . . . . . . . . . . . . 11

Objectives and Scope of the Study . . . . . . . . . . 12

Method of Approach. . . . . . . . . . . . . 13

Task 1--Water Inventory Analysis . . . . . . . 13

Task 2--Land Availability Analysis . . . . . . . 14

Task 3--Selection of Areas With High Potential . . . 14

Task 4--Selected Subbasin Studies......... 15

References. . . . . , , .,....... 16 
III WATER AVAILABILITY ANALYSIS . . . . . . . . . .

Introduction. . . . . . . . . . . . . . . . 17

The First and Second National Water Assessments . . . . 17

SRI Study Approach. . . . . . . . . . . . . . . 21

Preselection of Basins for Land Availability

Analysis . . . . . . . . . . . . . . . 21

Evaluation of Available Data Sources . . . . . . . ' 22

Development of Ground-Water Recharge Estimates . . . 22

Development of High and Low Estimates of Water

Availability . . . . . . . . . . . . . . 26

Water Availability Analysis Results . . . . . . . . 28

Limitations of the Uata . . . . . . . . . . . . . 3U

References...................... 37

Bibliography. . . . . . . . . . . . . . . 39

IV LAND AVAILABILITY . . . . . . . . . . . . . . . 41

Introduction. . . . . . . . . . . . . . . . 41

Objectives and Scope.............. . . 41

General Methodology. . . . . . . . . . . . 43

Land Inventory . . . . . . . . . . . . . . . 43

Average Annual Net Return: Conventional Agriculture and Forest Production .. . . . . . . . . . . . 45

Cropland ................... . . 45

Rangeland. .............. . . 51

Forest Land. . . . . . . . . . . . . . 53

Average Net Return from Two Categories of Biomass

Operalluns. . . . . . . . . . . . . . . . . . 54

Cropland: Food (Fiber)/Fuel and Fuel-Only

Oplluns. . . . . . . . . . . . . . . . . . 60

Fiber Fuel Comblnation . . . . . . . . . . 63

Average Nel Returi Fıom Fuel-Only Operation . . . . . . 68

Average Annual Net Return: Energy Farms. . . . . . . 73

Comparison of Conventional Agriculture and Biomace

Net Return. . . . . . . . . . . . . . . . 86

Available Acreage--Base-Case Scenario in 1985 . . . . . 88

Available Acreage--Base-Case Scenario in 2000 . . . . . . 88

Acreage Availability Response to Feedstock Price

Changes . . . . . . . . . . . . . . . 92

References. .................... 98 
V. SELECTION OF TEN SAMPLE SUBbASINS . . . . . . . . . 101

Summary of Subbasin Selection Procedure . . . . . . . 101

Selection of Subbasin Evaluation Factors . . . . . 101

Factor Welghting . . . . . . . . . . . 103

Subbas in Ranking . . . . . . . . . . . . 103

Evaluation of the Model Results . . . . . . . . . 106

VI SUBBASIN DESCRIPTIONS . . . . . . . . . . . . 109

Subbas in 101--Maine . . . . . . . . . . . . 109

Agricultural Factors .............. . 109

Land Factors.................. 110

Water Factors.................. 111

Economic Factors ............... 111

Energy Supply and Demand ............. . 112

Summary.................. . . . . 112

Subbasin 206--Northern Virginia and Western

Maryland. ................... 112

Agricultural Factors . . . . . . . . . 112

Land Factors .................. 113

Water Factors.................. 113

Economic Factors ................. 114

Energy Supply and Demand . . . . . . . . . . . 114

Sumnary. . . . . . . . . . . . . . . 115

Subbasin 302--South Carolina and Western North

Carolina. . . . . . . . . . . . . . . 115

Agricultural Factors . . . . . . . . . . 115

Land Factors . . . . . . ... . . . . . 116

Water Factors. . . . . . . . . . . . . . . 116

Economic Factors . . . . . . . . . . . 116

Energy Supply and Demand . . . . . . . . . . 117

Summary. . . . . . . . . . . . . . . 117

Subbasin 304--Northern Florida and Southern

Georgia ... . . . . . . . . . . . . . .

118

Agricultural Factors . . . . . . . . . . . 118

Land Factors . . . . ............ . . 118

Water Factors. . . . . . . . . . . . 119

Economic Factors . . . . . . . . . . . . 119

Energy Supply and Demand... . . . . . . . . 119

Summary. . . . . . . . . . . . . . . 120

Subbas in 306--Southwest Georgla . . . . . . . . . 120

Agricultural Factors . . . . . . . . . . 120

Land Factors... . . . . . . . . . . . 121

Water Factors. . . . . . . . . . . . . . 121

Economic Factors . . . . . . . . . . . . . 122

Energy Supply and Demand.............. 122

Summary. . . . . . . . . . . . . . 123 
Subbasin 404--Eastern Michigan. . . . . . . . . . 123

Agricultural Factors............... 123

Land Factors . . . . . . . . . . . . . 123

Water Factors. . . . . . . . . . ... 124

Economic Factors . . . . . . . . . . . . 124

Energy Supplý and Demand ... . . . . . . . ... 125

Summary. . . . . . . . . . . . ... 125

Subbasin 602--Northern Alabama and South Central

Tennessee..................... 125

Agricultural Factors............. 126

Land Factors . . . . . . . . . . . . 126

Water Factors.............. 126

Economic Factors............... 127

Energy Supply and Demand .............. 127

Summary. . . . . . . . . . . . . . 127

Subbasin 701--Minnesota .............. 128

Agricultural Factors . . . .......... 128

Land Factors.:. . . . . . . . . . . 128

Water factors................ 129

Economic Factors ................ 129

Energy Supply and Demand . . .......... 129

Summary. . . . . . . . . . . . . . 130

Subbasin 1101--Northern Arkansas and Southern

Missouri. . . . . . . . . . . . . . . . 130

Agricultural Factors . . . . . . . . . . . 130

Land Faccors . . . . . . . . . . . . . 131

Water Factors............... . . 131

Economic Factors . . . . . . . . . . . 132

Elleıgy Bupply alld Dellathd . . . . . . . . . . . 132

Summary. . . . . . . . . . . . . . . 132

Subbasin 1702--Northeast Oregon and Eastern

Washington. . . . . . . . . . ..... 133

Agicicullutal Facluls. . . . . . . . . . . . 133

Land Factors................ . . . . . 134

Water Factors. . . . . . . . . . . . . 134

Economic Factors . . . . . . . . . . . 135

Energy Supply and Demand ............. 135

Summary. ................ 136

References. . . . . . . . . . . . . 137

VII RANKING OF THE TEN SELECTED SUBBASINS : . . . . . . . . 139

Methodology ................... 139

Selection of Indicators . . . . . . . . . . . 141

Economics.................. 141

Environmenta1,................ 145 
Socloeconomic. . . . . . . . . . . 148

Legal and Institutional. . . . . . . . . . 150

Limitations of the Methodology. . . . . . . . . . 153

Study Results . . . . . . . . . . . . . ." 154

Indicator and Impact Area Weighting . . . . . . . . . 159

Weighted Ranking Results. ............... 159

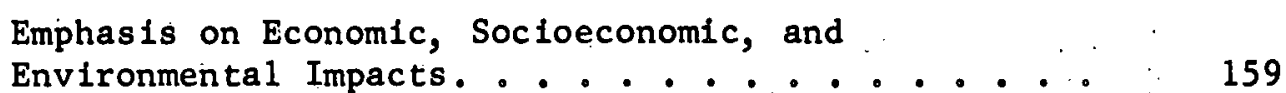

Indicators Equally Weighted. ........... 161

Impact Areas Equally Weighted. . . . . . . . . 161

Emphas is on Environmental Impacts.......... 165

Emphasis on Advantageous Biomass Production

Factors. . . . . . . . . . ... 165

Emphasis on Energy Farm Operating Costs...... 168

Summary .................... 168

References:................... 170

VIII METHODOLOGY FOR THE EVALUATION OF FUTURE ENERGY FARM

AREAS AND SITES . . . . . . . . . . . . . . . 171

Selecting the General Area. . .............. 171

Initial Screening of Subbasins............. . 171

Other Factors to Consider............ 175

Availability of Plant Design Assistance. . . . . . 177

Selecting the Specific Site........ . . . . 178

Stop 1--Produrt Potential (Supply) Analysis..... 178

Step 2--Market (Demand) Study........... 178

Step 3--Technical Feasibility Analysis . ....... 178

Step 4--Cost, Revenue, and Rate-of-Return ..... 179

Step 5--Preiminary Design and Return on 179

References. . . . . . . . .... . .... 181

APPEND IXES

A METHODOLOGY FOR ESTIMATING WATER USE AND PROJECTED STREAMFLOWS--SECOND NATIONAL WATER ASSESSMENT. ..

B ESTIMATED EXCESS WATER SUPPLY AND REQUIREMENTS BY SUBBASIN (DRY YEAR), 1985 AND 2000 . . . . . . . . 195

C COMPUTATIONAL METHOdOLOGIES. . . . . . . . . . 203 
D RANKING RESULTS FOR 71 SUBBASINS WITH EXCESS

WATER SUPPLIES ................ 211

E RESULTS OF THE RANKING OF THE TEN SELECTED

SUBBASINS. . . . . . . . . . . . . . . 215

F MANUAL OF WORKSHEETS FOR EVALUATING ENERGY,

FARMING AREAS. . . . . . . . . . . . . 


\section{ILLUSTRATIONS}

III-1 Location of Water Resource Subbasins . . . . . . 18

III-2 Water Consumed by Type of Use in the . . . . . . . . . . . . . . . 20

III-3 Consumption of Surface Water More than $50 \%$ of Surface Water Supply--2000........... 23

III-4 Basins Selected for Detailed Study of Land Ava1lab1lity ................ . . 2 24

III-5 Estimated Average Ground-Water Recharge per Square Mile............... 27

III-6 Excess Water Supply--2000, High Estimate . . . . . 31

III-7 Excess Water Supply--2000, Low Estimate. . . . . 32

$\begin{array}{ll}\text { III-8 } & \text { Excess Water Supply per Square M1le of } \\ & \text { Surface Area--2000, High Estimate. . . . . . . . }\end{array}$

III-9 Excess Water Supply per Square Mile of
Surface Area--2,000, Low Estimate. . . . . . . .

VII-1 Process for Scoring Each River Subbasin. . . . . . 140

VII-2 Final Ranking of Study Areas . . . . . . . . . 162

A-1 Methodology for Determining Instream Flow Requirements in Each Subbasin. ......... 189

A-2 Schematic Diagram of Water Analysis Model. . . . . 191 
TABLES

I-1 Excess Water Supply by River Basin--Low Estimate (1985) . . . . . . . . . . . . . . .

I-2 Avallable Acreage in the Year 2000 for the BaseCase Scenario... . . . . . . . . . . . 5

III-1 List of Selected Subbasins and Those They Represent. 25

III-2 Summary of Estimated Excess Water Supply by Major. River Basin--1985 and 2000 ............ 29

IV-1 Land Inventory Matrix for Conventional Cropland Commodities, Rangeland, and Forest Land in 71

Subbasins. . . . . . . . . . . . . . 44

IV-2 Classification of Conventional Cropland Commodities. $\quad 46$

IV-3 Yields of Conventional Cropland Commodities in 1985--Subbasin 206 . . . . . . . . . . . 47

IV-4 Conventional Cropland Commodities in 2000-Subbasin 206 ................. . . . . . 48

IV-5 Projected Prices for Conventional Cropland Commodities. ................ 50

IV-6 Sample FEDS Production Cost Budget for Conventional Crops--Soybeans, I11inois, Area 400........ 52

IV-7 Estimated Harvested Acreage and Yields from Commerctal Forestland in 21 Subbasins--1985...., 55

IV-8 Estimated Harvested Acreage and Ylelds from
Commercial Forestland in 21 Subbasins--2000. . ...

T.V-9 Range of Softwood Sawt Imber Stumpage Priccs. . . . . 57

IV-10 Range of Hardwond Sawtimher Stumpago Pricca. . . . 57

IV-11 Range of Softwood Pulpwood Prices. . . . . . . . . 58

IV-12 Range of Hardwood Pulpwood Prices. . . . . . . . 58

IV-13 Residue and Food/Fiber Dry Weight Factors for 1985.

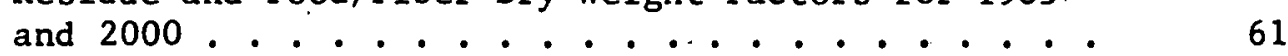

IV-14 Estimated Energy Feedstock in Subbasin 206--1985 ... . 62

IV-15 Estimatcd Energy Feedstuck in Subbasin 206--2000 . . 63

IV-16 Additional Production Costs Associated with Food (F1ber)/Fuel and Fuel-Oniy Blomass Operations in 1985 . . . . . . . . . . . . . . . . 
IV-17 Additional Production Costs Associated with Food (Fiber)/Fuel and Fuel-Only Biomass Operations in 2000 . . . . . . . . . . . . . . .

IV-18 Logging Residue Coefficients by Wood Type, Residue Type, and Geographical Sector. . . . . . .

IV-19 Estimates of Potentially Available Biomass per Acre of Harvested Commercial Forestland in 1985 ......

IV-20 Estimates of Potentially Available Biomass per Acre of Harvested Commercial Forestland in 2000 . . . .

IV-21 Estimates of Collection, Reduction, and Transportation Costs for Logging Residues in Two Regions. . . . . . . . . . . . . . . .

IV-22 Cost of Harvesting, Reducing, and Transporting Standing Biomass Using the Whole-Tree Method in. Vermont. . . . . . . . . . . . . . . . .

IV-23 Goals for Commercial Yields of Sweet Sorghum for Biomass Production ...............

IV-24 Estimated Sweet Sorghum Production Costs...... .

IV-25 Kenaf: Production Cost Estimates per Acre in. Selected Areas..................

IV-26 Representative Biomass Species for Selected Production Site Areas. . . . . . . . . . . . .

IV-27 Productivity at Selected Production Sites Current and Future Scenarios . . . . . . . . . . .

IV-28 Total Silviculture Production Costs at Ten Study

Sites: Current and Future Scenarios . . . . . .

IV-29 Matrix of Conventional Agriculture and Biomass Net Return Comparisons . . . . . . . . . . . . . .

IV-30 Available Acreage for the 1985 Base-Case Scenario: 71 Subbasins. . . . . . . . . .

IV-31 Available Acreage for the Year 2000 Base-Case Scenario: 71 Subbasins. . . . . . . . . .

IV-32 Available Acreage in 1985 as a Function of a 25 Percent Increase in the Price for Biomass

Feedstock: 71 Subbasins . . . . . . . . . .

IV-33 Available Acreage in 1985 as a Function of a 50 Percent Increase in the Price for Biomass Feedstock: 71 Subbasins . . . . . . . . .

IV-34 Available Acreage in 2000 as a Function of a 25 Percent Increase in the Price for Biomass Feedstock: 71 Subbasins . . . . . . . . . .

IV-35 Available Acreage in 2000 as a Function of a 50 Percent Increase in the Price for Biomass Feedstock: 71 Subbasins . . . . . . . . . . 
V-1 Factor Welghting Worksheet . . . . . . . . 102

V-2 Subbasin Rankings With Water-to-Land Balance Factor. 104

V-3 Subbasin Rankings Without Water-to-Land Balance

Factor . . . . . . . . . . . . 105

V-4 Subbasins Selected for On-Site Survey by SRI . . . . 107

VI-1 Private Ownership of Commercial Timberland in Subbasin 101 . . . . . . . . . . . . .

VI-2 Private Ownership of Commercial Timberland in Subbasin 304 ................. . . 118

VI-3 Large Farm Parcels--Albany Georgia Area. . . . . . 121

VII-1 Indicators Selected in Each Impact Area. . . . . . 142

VII-2 Economics Impact Summary . . . . . . . . . 155

VII-3 Environmental Impact Summary ........... 156

VII-4 Socloeconomic Impact Summary . . . . . . . . . 157

VII-5 Legal/Institutional Impact Summary . . . . . . 158

VII-6 Summary of Results if Economics, Environmental, and Soctoeconomic Factors are Emphasized . . . . . 160

VII-7 Summary of Results if Each Indicator is Equally Weighted . . . . . . . . . . . . . . . .

VII-8 Summary of Results if Each Impact Area is Equally Welghted . . . . . . . . . . . . . . . 164

VII-9 Summary of Results if Indicators Measuring Environmental Impacts are Heavily weighted. . . . .

VII-10 Summary of Results if Indicators Measuring Future Biomass Production Levels are Heavily Weighted...

VIII-i Summary of Results if Indicators Measuring Energy Farm Operating Costs are Heavily Weighted. . . . . 


\section{GLOSSARY}

$\begin{array}{ll}\text { ASR } & \text { Aggregated Subregion (subbasin) } \\ \text { AUM } & \text { Animal unit month } \\ \text { BOD } & \text { Biochemical oxygen demand } \\ \text { Btu } & \text { British thermal unit } \\ \text { CWT } & \text { Hundred-weight } \\ \text { DOE } & \text { U.S. Department of Energy } \\ \text { DOI } & \text { U.S. Department of the Interior } \\ \text { FEDS } & \text { Firm Enterprise Data System } \\ \text { GNP } & \text { Gross National Product } \\ \text { MGD } & \text { Militions of gallons per day } \\ \text { mi } & \text { Square miles } \\ \text { P.L. } & \text { Public Law } \\ \text { PRC } & \text { People's Republic of China } \\ \text { st } & \text { Streamflow } \\ \text { TDN } & \text { Total digestible nutrients } \\ \text { TSS } & \text { Total suspended solids } \\ \text { USDA } & \text { U.S. Department of Agriculture } \\ \text { USFWS } & \text { U.S. Fish and Wildife Service } \\ \text { USGS } & \text { U.S, Geological Survey } \\ \text { WRC } & \text { U.S. Water Resources Council } \\ \end{array}$


ABSTRACT

The purpose of this study was to assist the Department of Energy (DOE) in determining the physical and economic availbility of land and water resources for energy farming. Ten water subbasins possessing favorable land and water availabilities were ranked according to their overall potential for biomass production.

The study results clearly identify the Southeast as a favorable area for biomass farming. The Nurthwest and North-Central United States should alsu be cunsldered on the basis of their highly favnrable environmental characteristics.

SRI prepared both high and low estimates of water availability for 1985 and 2000 in each of 99 subbasins. For the high (optimistic) estimate of water availability (assuming instream flow requirements are $50 \%$ of U.S. Fish and Wildife Service estimates in the year 2000), 6 subbasins are projected to have an excess supply of more than 50 trillion gallons per day, and 12 subbasins to have no excess supply. For the low (pessimistic) estimate ( $80 \%$ of USFWS estimates), 31 subbasins have no excess supply, 32 subbasins have excesses of 1 to 5 trillion gallons per day, and 36 subbasins have more than 5 trillion gallons per day of excess supply; only 4 subbasins are projected to have an excess supply of more than 50 trillion gallono per day.

Subbasins in which surface water consumption was more than $50 \%$ of surface water supply were eliminated from the land availability analysis, leaving 71 subbasins to be examined. SRI determined the amount of acreage potentially available for biomass production in these subbasins through a comparison of estimated average annual net returns developed for conventional agriculture and forestry with net returns for several biomass production options. This net return analysis indicated that less than $0.5 \%$ of a.l1 the land in the 71 subbasins will be potentially available for biomess production in 1985. However, conditions projected for 2000 indicate that a substantial increase in the potential acreage used for such an enterprise, nearly 280 million acres, or $23 \%$ of the total land area considered in this analysis, was determined to be potentially available in 2000. Geographlcally, the available acreage is concentrated in the Upper Mississippi and South Atlantic Gulf region.

In addition to a computerized method of ranking subbasins according to their overall potential for biomass production, a methodology for evaluating future energy farm locations was developed. This methodology included a general area selection procedure as well as specific site analysis recommendations. Thirty-five general factors and a five-step site-specific analysis procedure are described. 
PREFACE

The study results summarized in this document are the most recent of many published by SRI International concerning the subjects of biomass crop production, conversion; fuel products, and markets. Unlike typical previous SRI reports, this document presents the results of an analysis of water and land resource availabilities, regional development potential, and continental U.S. siting factors, rather than of specific biomass technologies, resource bases, or production/conversion economics. Many of the earlier SRI reports, as well as other sources of information on basic requirements for energy farm configurations, operations, and economics, are cited in the references for Section VIII.*

The study procedure was a unique approach to the analysis of U.S. land and water resources for biomass that fully considered the economics of competitive product production and net rate of return to the farmer. The report also includes selected sample survey data on area characteristics and development factors. Water avallabllity projections are based on the analysis of data from numerous sources and the refinement of information on stream flows, ground-water supplies, current consumption, and future requirements.

Because of the diversity of the subject matter, professionals from three SRI organizations cooperated on the study. The organizations are:

- The Energy Center (EC)

- The Center for Resource and Environmental Studies (CRESS)

- The Food and Agricultural Industries Department (FAI).

In addition to the authors of the Final Report, F. A. Schooley, Project Leader (EC), S. J. Mara (CRESS), D. A. Mendel (FAI), P. C. Meaglier (EC), and E. C. So(CRESS), several other professionals also participated in the study. They are R. L. Hays (CRESS), J. S. Smith (FAI), and C. Hostetter (EC). R. L. Dickenson, Manager of the SRI Fuels and Power Management Department of the Energy Center, served as the project supervisor.

Subbasin site data were collected by the staff members 1 isted in the following tabulation.

* References for each section of this report are 11sted at the end of the sections in which they are cited. 


\begin{tabular}{|c|c|c|}
\hline Name & $\begin{array}{l}\text { Subbas in } \\
\text { No. }\end{array}$ & Area \\
\hline S. J. Mara & $\begin{array}{l}101 \\
404\end{array}$ & $\begin{array}{l}\text { Main } \\
\text { Eastern Michigan }\end{array}$ \\
\hline E. C. So & $\begin{array}{r}1702 \\
701\end{array}$ & $\begin{array}{l}\text { Northeastern Oregon and Eastern } \\
\text { Washington } \\
\text { Minnesota }\end{array}$ \\
\hline $\begin{array}{l}\text { C. Hos te tter } \\
\therefore\end{array}$ & 302 & $\begin{array}{l}\text { Northern Alabama and South- } \\
\text { Central Tennessee } \\
\text { Souch Carolina and Western North } \\
\text { Carolina }\end{array}$ \\
\hline Fred A. Schooloy & $\begin{array}{l}304 \\
306\end{array}$ & $\begin{array}{l}\text { Wcotern Georgia } \\
\text { Northern Florida and Southern } \\
\text { Georgia }\end{array}$ \\
\hline Roy L. Hays & 206 & $\begin{array}{l}\text { Northern Virginia and Western } \\
\text { Maryland } \\
\text { Northern Arkansas and Southern } \\
\text { Missouri }\end{array}$ \\
\hline
\end{tabular}

Much of the land availability data and all of the site descriptions were prepared by D. A. Mende1. The water avallability analysis was performed by S. J. Mara, and the ten-site ranking methodology was prepared by $E$. C. So. The sections on subbagin selection and the methodology for site selection were developed by F. A. Schooley. P. Meagher provided computer modeling support for the site selection and land avallability taske.

Dr. Roscoe Ward and Mr. Nello Del Gobbo of the Blomass Energy Systems Branch of the Department of Energy provided valuable guldance throughout this project. Dr. Ward served as Technical Manager for the study. 


\section{SUMMARY AND CONCLUSIONS}

\section{Sumnary of Ranking Results}

The study results clearly 1dentify the Southeast as a favorable area for blomass farming. The Northwest and North-Central United States should also be considered on the basis of their highly favorable environmental characteristics. When factors measuring favorable biomass yields and production costs are considered, the North-Central United States does not compare as favorably, but the Southeast and Northwest still rank high.

On the basis of the analysis of 71 subbasins consldering basic land and water avallability factors, the most desirable biomass farm areas will be:

(1) North and South Carolina (Subbasins 302 and 301)

(2) Northern Florida and Georgia (Subbasins 303, 304, and 306)

(3) Northern Virginia and Maryland (Subbasins 205 and 206)

(4) Alabama and Central Tennessee (Subbasins 307, 308, and 602)

(5) Kentucky and Ohio (Subbasins $50 \dot{5}$ and 506)

(6.) Minnesota (Subbasin 701).

A sample of 10 subbasins with desirable land and water avallability characteristics, giving heavy weighting to advantageous environmental factors, ylelded high rankings for the following areas:

(1) Minnesota (701)

(2) Eastern Oregon and Washington (1702)

(3) Western Georgia (306)

(4) Northern Florida (304)

(5) Western Michigan (404).

With the same 10-subbasin sample and heavy welghting of advantageous blomass production factors, the following areas ranked high:

(1) Northern Flor 1da (306)

(2) Eastern Georgia (304)

(3) South Caroilina and Eastern North Carolina (302)

(4) Eastern Oregon and Washington, (1702)

(5) Northern Virginia and Eastern Maryland (206). 
With the same 10-subbas in sample and heavy weighting for advantageous energy farm operating costs, the following areas ranked high:

(1) Eastern Oregon and Washington (1702)

(2) Eastern Georgia (304)

(3) Northern Florida (306)

(4) South Carolina and Eastern North Carolina (302)

(5) Northern Arkansas and Southern Missouri (1101):

With the same 10-subbasin sample and equal weighting to all factors, the following areas ranked high:

(1) Eastern Oregon and Washington (1702)

(2) Northern Florida (306)

(3) Minnesota (701)

(4) Eastern Georgia (304)

(5) Northern Alabama and Mid/South Tennessee (602):

\section{Water Availability Analysis}

SRI prepared both high and low estimates of water availability for 1985 and 2000 in each of 99 subbasins, and summarized them for $18 \mathrm{U} . \mathrm{S}$. rlver bastins. The bases for the profectiono were Water Resources Council stream flow data, U.S. Fish and Wildlife Service (USFWS) information on instream flow requirements, U.S. Geological Survey (USGS) data, and SRI estimates on ground-water supplies. Low estimates asoume in. stream flow requirements at 80 percent of USFWS estimates, and are summarized, by basin, in Table I-1.

We have also summarized the high and low estimates of excess water supply, by subbasin. The difference between the high and low estimates is substantial in subbasins where instream flow requirements represent a high percentage of the projected streamflow. For the high (optimistic) estimate of water availability (assuming instream flow requirements are 50 percent of USFWS estimates in the year 2000), 6 subbasins are projected to have an excess supply of more than 50,000 million gallons per day, and 12 subbasins to have no excess supply. For the low (pessimistic) c3timate ( 80 percent of USFW estimates), only 1 subbas in is projected to have an excess supply of more than 50,000 million gallons per day, and 35 subbasins to have no excess supply. 
Table I-1

EXCESS WATER SUPPLY BY RIVER BASIN--LOW ESTIMATE (1985)

\begin{tabular}{|c|c|c|c|}
\hline & Basin No. & $\mathrm{MGD}^{*}$ & MGD/Square Mile \\
\hline $\begin{array}{l}100 \\
200 \\
300\end{array}$ & $\begin{array}{l}\text { New England } \\
\text { Mid-Atlantic } \\
\text { South Atlantic-Gulf }\end{array}$ & $\begin{array}{r}48.2 \\
44.5 \\
100.7\end{array}$ & $\begin{array}{l}0.67 \\
0.38 \\
0.36\end{array}$ \\
\hline $\begin{array}{l}400: \\
500 \\
600\end{array}$ & $\begin{array}{l}\text { Great Lakes } \\
\text { Ohio } \\
\text { Tennessee }\end{array}$ & $\begin{array}{l}31.3 \\
62.8 \\
26.9\end{array}$ & $\begin{array}{l}0.28 \\
0.39 \\
0.66\end{array}$ \\
\hline $\begin{array}{l}700 \\
800 \\
900\end{array}$ & $\begin{array}{l}\text { Upper Mississippi } \\
\text { Lower Mississippi } \\
\text { Souris-Red-Rainy }\end{array}$ & $\begin{array}{r}23.8 \\
0.0 \\
10.4\end{array}$ & $\begin{array}{l}0.13 \\
0.0 \\
0.18\end{array}$ \\
\hline $\begin{array}{l}1000 \\
1100 \\
1200\end{array}$ & $\begin{array}{l}\text { Missouri } \\
\text { Arkansas-White-Red } \\
\text { Texas }\end{array}$ & $\begin{array}{l}5.0 \\
0.7 \\
0.0\end{array}$ & $\begin{array}{l}0.0 \\
0.0 \\
0.0\end{array}$ \\
\hline $\begin{array}{l}1300 \\
1400 \\
1500\end{array}$ & $\begin{array}{l}\text { Rio Grande } \\
\text { Upper Colorado } \\
\text { Lower Colorado }\end{array}$ & $\begin{array}{l}0.5 \\
3.9 \\
0.4\end{array}$ & $\begin{array}{l}0.0 \\
0.03 \\
0.0\end{array}$ \\
\hline \multirow[t]{2}{*}{$\begin{array}{l}1600 \\
1700 \\
1800\end{array}$} & $\begin{array}{l}\text { Great Basin } \\
\text { Paclific Northwest } \\
\text { California }\end{array}$ & $\begin{array}{r}2.9 \\
177.4 \\
6.6 \\
\end{array}$ & $\begin{array}{l}0.02 \\
0.64 \\
0.04\end{array}$ \\
\hline & U.S. Tota 1 & 546.0 & 0.18 \\
\hline
\end{tabular}

Land Availability Analysis

Subbasins in which surface water consumption was more than 50 percent of surface water supply were eliminated from the land availability analysis, leaving 71 subbasins to be examined.

The acreage examined in the land availability analysis was restricted to 13 land use types within land capability classes. I through IV.t SRI determined the estimates of the amount of acreage potentially available for biomass production through a comparison of estimated average annual net returns developed, on the one hand, for conventional agriculture and

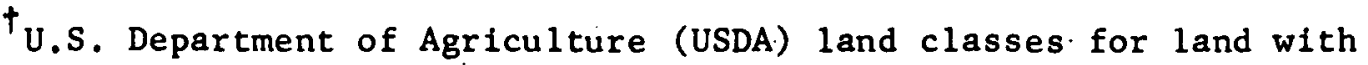
gentle slopes and other characteristics favorable to agriculture.
} 
forestry, and, on the other hand, for three primary categories of biomass options. A fundamental tenet of the land availability analysis was that the acreage would be used by the agricultural operation that generated the largest annual net return.

The three primary categories of biomass options are:

(1) Crops grown for fuel only"

$\therefore$....., (2) Food (fibers)/fuel combinations

(3) Specialty crops such as kenaf and sweet sorghum. $\therefore \ldots$

SRI identified 13 biomass production options within these three primary categories.

Calculations of net return ${ }^{*}$ were developed through an estimate of yields per acre, prices to be paid, and associated production costs for both conventional agriculture and forestry, as well as other biomass production options.

SRI determined the amount of acreage potentially available for biomass production in 1985 and 2000 by comparing the annual net returns from the biomass production options with those of conventional agriculture and forestry; 72 net return comparisons were identified. Using a computerized procedure, SRI duplicated this process for all 71 subbasins, in land capability classes I through IV, for the years 1985 and 2000." The regional results, by water basin, for the year 2000 are summarized in lable I-2.

The net return analysis indicated chat less than 0.5 perceit of all the land in the 7.1 subbasins is projected to be potentially avallable for biomass production in 1985. However, conditions projected for 2000 indicate that a substantial increase in the amount of acreage could be used for such an enterprise; nearly 280 million acres, or 23 percent of the total land area considered in this analysis, were determined to be potentially available. Geographically, the available acreage was concentrated in the Upper Mississippi and South Atlantir fillf reginn.

In addiliun lu cieating lie base-case scenario, SRI assessed the competitive position of all 13 biomass options by raising the price offered per dry run by 25 percent in 1985 and 50 percent in 2000. A11 other parameters were held constant.

* Net return $(\mathrm{NR})=$ yield $(\mathrm{Y})$ of the commodity in production units per acre (e.g., bushels, tons) times selling price (P) of the conmodity in dollars per production unit, minus the cost (C) of production in dollars per acre--that is, $\mathrm{NR}=\mathrm{Y} \times \mathrm{P}-\mathrm{C}$. 
Table I-2

AVAILABLE ACREAGE IN THE YEAR 2000 FOR THE BASE-CASE SCENARIO

(Thousands of Acres)

\begin{tabular}{|c|c|c|c|c|c|}
\hline \multirow[b]{2}{*}{ Basin } & \multicolumn{3}{|c|}{$\begin{array}{c}\text { Categories of Biomass } \\
\text { Operation } \\
\end{array}$} & \multirow[b]{2}{*}{$\begin{array}{c}\text { Acreage } \\
\text { Total }\end{array}$} & \multirow{2}{*}{$\begin{array}{c}\text { Total } \\
\text { Percentage } \\
\text { of Land } \\
\text { Area } \\
\end{array}$} \\
\hline & $\begin{array}{c}\text { Food } \\
\text { (fiber) } \\
\text { Fuel } \\
\end{array}$ & $\begin{array}{l}\text { Fue 1 } \\
\text { Only }\end{array}$ & $\begin{array}{l}\text { Energy } \\
\text { Farms }\end{array}$ & & \\
\hline New England & 273.88 & -- & $1,128.14$ & $1,402.02$ & 3.4 \\
\hline Mid-Atlantic & $9,172.19$ & $\cdots$ & $6,475.88$ & $15,648.07$ & 24.4 \\
\hline South Atlantic Gulf & $27,530.95$ & -- & $13,930.27$ & $41,461.22$ & 17.9 \\
\hline Great Lakes & $8,216.91$ & -- & $23,011.78$ & $31,228.69$ & 40.0 \\
\hline Ohio & $10,492.56$ & -- & $10,481.32$ & $20,973.88$ & 29.9 \\
\hline Tennessee & $9,862.68$ & -- & $9,035.98$ & $18,898.66$ & 32.6 \\
\hline Upper Mississippi & $45,854.37$ & $\cdots$ & $12,872.08$ & $58,726.45$ & 36.5 \\
\hline Missour 1 & $35,428.21$ & -- & 950.68 & $36,378.89$ & 19.9 \\
\hline Arkansas White-Red & $8,619.60$ & -- & $5,228.77$ & $13,848.37$ & 25.8 \\
\hline Texas Gulf & $10,330.64$ & -- & $12,937.35$ & $23,267.99$ & 45.0 \\
\hline Upper Colorado & $1,848.49$ & - & -- & $1,848.49$ & 2.8 \\
\hline Lower Colorado & 625.99 & -- & -- & 625.99 & 1.4 \\
\hline Pacific Northwest & $9,825.30$ & $=$ & $5,202.91$ & $15,028,21$ & 11.5 \\
\hline Total & $178,081.77$ & -- & $101,255.16$ & $279,336.93$ & 22.6 \\
\hline
\end{tabular}

The results of the price sensitivity analysis mirror those of the base case. Available land in 1985 increased to $394^{\circ}$ million acres as the feedstock price rose to 50 percent above the basecase level. This acreage constitutes 32 percent of the total land area under analysis. The majority (63 percent) of land was captured by a food (fiber)/fuel combination, whereas energy farms accounted for 21 percent of the potential acreage. The predominant biomass options remain a food/fuel combination for close-grown crops and silvicultural energy farms.

With a 50 percent price increase, avallable acreage for biomass production in 2000 rose to 493 million acres, accounting for 40 percent of the land area analyzed. The most significant finding is that energy farms captured 54 percent of total avallable acreage with a 25 percent price increase and 73 percent of the available land with a 50 percent price increase. A silvicultural energy farm remained the most attractive 
option. As seen before, a food/fuel combination for close-grown crops captured more than 90 percent of the land associated with combination biomass enterprises.

Subbasin Survey Results

SRI evaluated subbasins on the basis of information obtained from on-site surveys and on the results of the land and water availability analyses. A formal computer modeling procedure for both the selection of subbasins for onsite survey and for comparative ranking was then developed. The 10 sites are discussed in approximate of overall ranking in the paragraplis lhat follow.

\section{Subbasin 1702--Northeastern Uregon and Liastèrn Washingron}

The prospects for the development of a biomass enterprise in Subbasin 1702 are quite favorable. Agricultural earnings in 1974 were 20 percent of the subbasin's total; 90 percent of total employment was in the agricultural sector. The average farm size in 1974 was 1,894 acres, and approximately 31 percent of all farms exceeded 1,000 acres. In addition, approximately 22.4 million acres of federally controlled forestland and public lands are held in this subbasin. Should any of this land become available, it could offer feasible locations for energy farms. Although sufficient amounts of water are available, water quality has been identified as a major problem during periods of low streamflow. Average precipitation is low in many parts of the subbasin, and approximately 42 percent of all streams do not meet water quality standards. However, the low incremental fertilizer burden (stream pollution impact from new farms) would not cause a further deterioration in water quality.

Electricity demand is projected to increase 81 percent between 1985 and 2000. Currently, no major utility generating system is operating in this subbasin. The subbas in received moderately high ratings during the process used to select 10 sites for detailed analysis, and very high ratings during the formal computerlzed comparisons. The subbasin was top-rated when evaluation factors were equally weighted and when energy-farm operating costs received heavy weightings.

\section{Suhhasin 304--Nor thern Florida and Southern Genrgia}

The prospects of the development of a biomass enterprise in Subbasin 304 are generally favorable. The average-sized farm in several counties exceeds 1,000 acres, and large amounts of both federally and privately held commercial timberland are found in the subbasin. 
Surface water and groundwater are abundant. Water quality problems can be minimized with thorough planning and execution, and demand for energy is expected to increase substantially between 1985 and 2000 . Although sufficient generaling capacity currently exists, electric power could be generated in this subbasin and sold to other areas. The subbasin contains an established agricultural base, large timberland ownerships, a long crop-growing season with conslderable potential for biomass production and future energy farming. Subbasin 304 ranked high compared with the nine: other subbasins that were formally evaluated. In cases where weighting was varied to reflect either (1) an emphasis on environmental indicators or (2) an emphasis on biomass production indicators or (3) an emphasis on energy-farm operating cost factors, Subbasin 304 rankéd within the top 40 percent of the sites evaluated.

\section{Subbasin $306--$ Southwestern Georgia}

The prospects for the establishment of a biomass enterprise in Subbasin 306 are quite favorable. The existence of 70-80 cropland clusters of approximately 25,000 acres each and tracts of federally controlled forestland are significant assets that could permit largescale energy farming.

- Surface water and groundwater are abundant. Water quality is only moderately good, but the projected incremental fertilizer burden (stream pollution impact) from a biomass enterprise should be sufficiently low to avoid further declines. The need for additional energy is apparent; electricity demand is projected to increase 62 percent over current generating capacity by 2000 .

Eubbasin 306 ranked high compared with other oubbaoins evaluated during the analysis; it was rated first when heavy weighting was given to biomass production factors.

\section{Subbasin 302--South Carolina and Western North Carolina}

The need for additional energy sources in Subbasin 302 is apparent. Electricity demand is expected to increase 170 percent over current requirements by 2000. However, the prospects for the formation of a biomass enterprise in Subbasin 302 are varied. The majority of agricultural land is held by small family farms, although in a few counties, many farms are larger than 1,000 acres. The agricultural economy generates a minor portion of the basin's total earnings, and is projected to increase at a substantially lower rate than both the manufacturing sector or the general economy in the area. 
A large quantity. of federally controlled forestland is contained in Subbasin 302. However, the avallability, of this land is predominantly a political question that must be resolved by leglslative and agency decisions. Private ownership of commercial forestland is primarlily concentrated in smaller tracts.

Water is abundant, but water quality is a potentlal problem. Good planning and operation can mitigate environmental problems if such issues as energy development are determined to take precedence. Projected energy demand is expected to require increased capacities, and, as mentioned earlier, the need for new energy sources is evident. If federally controlled timberland can be partially devoted to energy farms, the production of useful fuels and chemicals may become feasible.

Subbasin 302 ranked high in comparison with the other subbasins evaluated. When heavy weights were placed on biomass production factors and farm operating costs, Subbas in 302 ranked third and fourth out of the 10 sites formally evaluated.

\section{Subbas in 602--Northern Alabama and South Central Tennessee}

The prospects for the establishment of a cropland or silviculture energy farm in Subbasin 602 are fair to poor. The average farm size in this subbasin is the smallest of all 10 subbasins, and fewer than 2 percent of all farms exceed 1,000 acres. Private holdings of commercial farmland are quite small, and the amount of federally controlled forestland in this subbasin is the smallest of all 10 subbasins surveyed. However, water is abundant, its quality is high, and electricity demand is projected to increase by approximately 70 percent between 1985 and 2000 .

Subbas in 602 ranked in the middie to low position when compared with the $n$ ine other subbasins formally evaluated during the computerlzed analysis. Regardless of the welghting system used, the subbas in ranked no higher than fifth, when equal welghts were given to all 16 factors analyzed.

\section{Subbasin 701--Minnesota}

Conditions for the establishment of a blomass enterprise in Subbasin 501 are not favorable despite the region's large agricultural base. Most agricultural land is concentrated in small family farms, and fewer than 2 percent of all farms exceed 1,000 acres. Private ownership of commercial forestland is held in small parcels by individuals. Substantial quantities of federally controlled forestland are located in this subbasin, but the avallability of these lands is uncertain. 
Water quality is high, although the incremental fertilizer burden (stream pollution impact) from an acre of land devoted to biomass production is sufficiently high that it could contribute to a deterioration in water quality. Electric energy demand is projected to increase modestly between 1985 and 2000. However, the 1975 generating capacity of the major utility system in Subbasin 701 is 86 percent of the projected demand for the year 2000. The remaining 14 percent may not provide a sufficient market to warrant the establishment of energy farms in Subbasin 701: :

Subbasin 701 ranked high when advantageous environmental factors were given a heavy weight. However, in all other comparisons completed, the subbasin ranked in the bottom half of the 10-site population dispersion.

\section{Subbasin 1101--Northern Arkansas and Southern Missouri}

The need for alternative energy sources in subbasin 1101 is clear. Electricity demand is expected to increase approximately 1,900 percent between 1985 and 2000. Currently, no electric power is generated there. However, the prospects for the establishment of a blomass enterprise are not particularly favorable. The vast majority of cropland is held in small family farms; only 3 percent of all farms exceed 1,000 acres. A large quantity of federally controlled forestland, however, is contained in Subbasin 1101 .

Although a large percentage of the labor force is employed in the agricultural sector, the agricultural economy generates a minor portion of the subbasin's total earnings, and is expected to increase significantly less than either the manufacturing sector or the general economy. Water quality is poor, and some supply problems exist during periods of low steamflow. In addition, the projected incremental fertilizer burden is the highest of all subbasins surveyed and would further deteriorate water quality.

Subbasin 1101 ranked in the middle-to-low position when compared with the nine other subbasins formally evaluated during the analysis. Regardless of the welghting system used, the subbasin ranked no higher than fifth (it ranked fifth when heavy weights were assigned to advantageous energy-farm operating costs).

\section{Subbas in 101--Ma1ne}

The prospects for the establishment of energy farms in Subbas in 101 are mixed. The absence of large tracts of agricultural land, coupled with a declining agrlcultural economy, discourages the development of 
new crop-based energy farms. Conversely, large tracts of commercial timberland are found in this subbasin, and water resource issues will not impede the formation of silviculture-based energy farms. Water is abundant and of high quality. The development of local cost-effective biomass enterprises could help meet projected increases in electricity demand and could supply other useful fuels such as methane and methanol. However, Subbasin 101 ranked low in comparison to the nine other subbasins formally evaluated regardless of the weights assigned to the factors evaluated.

Subbas1.n 404---Western M1ch1gan

The need for additional energy sources in Subbasin 404 is apparent. Electric energy demand is expected to increase 110 percent over present generating capacity by 2000 . However, the prospect for the establishment of a biomass enterprise in Subbasin 404 are generally unfavorable. The vast majority of cropland is held in small family farms, and fewer than 1 percent of all farms exceed 1,000 acres. The agricultural economy generates a minor portion of the subbasin's total earnings, and those earnings are expected to increase substantially less than earnings in the manufacturing sector or the general economy. Although water quality is high, localized problems of water supply exist, and the region is extremely susceptible to droughts. These supply problems could constrain the development of an energy farm.

$\Lambda$ largc quantity of federally controlled forest land is contalined in Subbasin 404. If portions of this federally controlled timberland can be devoted to energy farms, the production of needed fuels and chemicals may be feasible energy alternatives.

Subbasin 404 ranked 10w in comparison with other subbasins evaluated. Regardless of the weighting system used, the subbasin ranked no higher than fifth (it ranked fifth when advantageous environmental factors were given heavy weighting).

\section{Subbasin 206--Northern Virginia and Western Maryland}

Cunditione for the cotabliohment of a biomass enterprise are not particularly favorable in Subbasin 206. Most agricultural land is concentrated in small family farms, although some concentration of large farms does exist in West Virginia. Private ownership of commercial forestland is held in small parcels. Large amounts of federally controlled foreseland are located within this subbasin, but their availability is uncertain. The use of federally controlled forestland is not an agronomic or economic issue, but rather, a political question beyond the scope of this analysis. 
Water quality is high, although problems arise with erosion, flood-. ing, and saltwater intrusion. Energy demand is projected to increase significantly over current generating. capacity by. 2000 . The need for. additional energy sources is evident, but the establishment of a biomass enterprise in Subbasin 206 may not be the best alternative because of the currently fragmented ownership of farmland, high land costs, and lack of an established agricultural base.

Subbasin 206 ranked low in our formal comparisons of economic, environmental, social, legal, and institutional factors, but improved its position to rank fifth when heavy weights were given to factors measuring favorable elements of biomass production, such as the potential energy value of production from new energy farms, added yield owing to seasonality, and favorable farm sizes. 


\section{INTRODUCTION}

One of the most important research areas in the Federal Fuels from Blomass Energy Program is the study of water availability for biomass production. Because water availability will be a primary constraint on biomass production in most regions of the United States, it is essential that the problems of water availability by region, competitive water demands, and the social and economic impacts that would result from water use for biomass production be addressed.

Much of the land in the United States not currently being cropped could be devoted to energy farms. A 1967 inventory by the U.S. Department of Agriculture (USDA) and a complementary survey by the Soil Conservation Service in 1975 revealed that of the total U.S. land area, 265 million additional acres of land with and without limitations could be considered suitable for conversion to cultivation. However, of this total, only a portion can be considered currently well adapted. Usability for cultivation will depend on general water avallability and public programs to provide irrigation water, drainage improvement, and soil conservation.

Studies comparing dry and irrigated farming techniques have shown that irrigation permits higher economic returns (sometimes as much as 17 times higher). ${ }^{1}$ Controlling both the amount and time of water application can have dramatic effects on yields. In addition, irrigation can reduce risks of crop quality loss resulting from poor soil conditions, and salt accumulation in soils in arid areas. Based upon U.S. Water Resources Council (WRC) reports, the irrigated land area in the United States will increase by $20 \mathrm{million}$ acres during the next 50 years. ${ }^{2,3}$

Wctland problems in the Southeast are so widespread that large-scale drainage outlet works are necessary for reclamation. A high potential exists for land reclamation through additional public investment in onfarm drainage projects in many delta and coastal regions.

The severe water shortage in the western and midwestern states is currently limiting additional cultivation in these areas. Interbasin (Litlerregional) transfers could alleviate such water shortages, given economic incentives and the removal of social, political, and legal constraints on such transfers.

Although water resource limitations are very important, they must be considered in light of other factors. High production costs, small farm units, higher value cropping alternatives, climatic limitations, and other economic considerations will all influence the decision to convert land to hiomass production. Consolidation of currently fragmented acreage in some U.S. areas into profitable units depends on the slze of the tracts, 
their proximity to existing farm lands, and the ownership characteristics of the tracts. Much of the land will require special conservation projects and practices to minimize soil and water erosion. Also, energy farm investors will have to be assured of a long-term profit to offset the capital costs associated with bringing marginal lands into production. If biomass farming is to represent a feasible alternative energy source, it must not only be economically competitive with other energy sources, but must also provide a favorable return in comparison with food and fiber crops.

Land avallability has been studied in previous research funded by the Department of Energy (DOE), but a detalled analysis of water ava11ability for energy farms and an energy farm land economic rate of return analysis had not been conducted. Because of these deficiencles, the amount of land that could physically support future energy farms was not known for the 99 major water subbasins that comprise the 2.3 billion acres of U.S. 1and area.

\section{Objectlves and Scope of the Study}

The objectives of this study were to:

- Analyze and delineate the physical, economic, and other factors that constitute the substantive bases determining water availability for biomass production in major U.S. water subbasins

- Determine the current and future availability and usefulness of U.S. water and land resources for supporting biomass production in each of the major water subbasins in the coterminous United States, given the existing and potential problems and constraints that may affect such use

- Rank selected sites within basins possessing favorable land and water availahilities according to their overall potential for biomass production.

The study is 1 imited to an analysis of the availability of 1 and and water for terrestrial crops grown within the continental United States; it does not address aquatic crops grown on land or in a marine environment. The issue of resource avallability for aquatic crops has been addressed in earlier studies. ${ }^{4-6}$ Furthermore, this report docs not include an analysis of specific energy crops developed for their drnught-tolerance or an analysis of the impact of new genetically engineered crops designed for growth in arid or semiarid areas. It was assumed that conventional crops and residues would be produced for their energy content or for their combined value as sources of energy, food, fiber, fertilizer, or feed. It was also assumed that crop production would respond normally to variations in avallability of water, solar radiation, and other resources and that this lack of adequate amounts of usable water in an area would significantly reduce crop yields and the potential for energy farm development. Consequent1y, an analysis of shortages in WRC. Aggregated Subregions (see section III) was performed to reduce the number of areas for 
which a land avallabllity study and a detalled energy crop rate of return analysts was necessary.

\section{Method of Approach}

SRI performed four specific tasks designed to determine the availabllity of land and water. resources to support biomass production. Water availability data (from Task 1) were compared with land availability data (from Task 2) to determine potential energy farm acreage in each water subbasin (Task 3). Subsequent1y, 10 subbasins that seemed to have a high potential for energy farm development were evaluated (Task-4). The four tasks are described as follows:

\section{Task 1--Water Inventory Analysis}

Task 1 involved the acquisition and analysis of the most recent WRC and U.S. Geological Survey (USGS) groundwater, precipitation, water use, river flow, and surface water information. The WRC data were used as a preliminary measure of water balances in the 99 subbasins in the contiguous United States and as the initial inputs for Task'2, Land Avallability Analysis. USGS information was used to supplement the WRC data in regions where groundwater use is a feasible alternative.

Task 1 aslo required collection review, analysis, and summariazation of information relating to the total water resources of the continental United States, including future water demand and supplies. Sources included:

- SRI related research studies

- Industry linformation on resourceo for onergy production

- USGS water data, maps, and surveys

- USDA statistical bulletins and handbooks

- U.S. Department of the Interior (DOI) studies

- Corps of Engineers studies

- National laboratory studies (Argonne, Oak Ridge, et a1.) relating to water availability for energy development.

During Task 1, water sources and consumption were summarized by subbasin for the current period and for the year 2000. This effort required an analysis of water sources including groundwater, precipitation, surface water, river water flows, well capacities, lake reserves, reservoirs, and imports from other basins, as well as an analysis of water consumption, such as industrial, agricultural, and residential withdrawals, ocean discharge, exports to other basins, and evapotranspiration.

The end result of Task 1 was a classification of each water subbasin by amount, of water available for energy projects. Specifically, SRI determined the potential amounts of water (in acre-feet) available in each 
subbasin to support energy farming, conversion to useful fuel, and the objectives of the Fuels From Biomass Program.

\section{Task 2--Land Availability Analysis}

Task 2 involved the development of a matrix of land capab1lities and corresponding land use patterns from existing USDA Soil Conservation Service and U.S. Forest Service data. This matrix included Land Capability Classes I to IV and all subbasins with an adequate water supply as indicared by WRC daca.

Task 2 also involved determining an average cconomic return per acrc for the various land capability classes and corresponding land uses for selected water basins that were representative of surrounding basins. The matrix of average economic returns corresponded to the acreage matrices developed for land capabilities. Data from the Firm Enterprise Data System of the USDA Economic Research Service were used extensively, but when data were unavallable, appropriate SRI assumptions and estimates were made.

For Task 2, SRI also estimated biomass yields and production costs as a function of Land Capability class. These estimates required the development of an economic return for a biomass enterprise or combination biomass/food crop enterprise for each land class based on the assumption of a reasonable price per ton for the feedstock.

Task 2 included a determination of the quantity of energy crop or combination energy/food crop acreage available in each water basin area that contains an adequate water supply. On the basis of our estimates of the average return for biomass by land capability class, the land that. produced an economic return less than the return for the corresponding biomass enterprise was assumed to be economically available for biomass produclion.

The last subtask of Task 2 was to calculate the effect on acreage availability of a 25 percent and a 50 pcrcent increase in the price per ton pald for the biomass feedstock. Th1s effort required the calculation of new crop rates of return in each water surplus subbasin. For each subbasin, the estimates of the adjusted differential between the biomass return and the return from the current land use allowed the calculation of revised amounts of acreage available for energy farming.

\section{Task 3--Selection of Areas With High Potential}

Task 3 Involved selecting of 10 water subbasins with high potential water and land avallabllity for detalled analysis during task 4. This effort required: (1) comparing energy farm resource requirements with energy farm and water resource data developed in Task 1 and 2; (2) rating various biomass production factors appropriate for each subbasin, such 
as rainfall, stream flow, and area energy demand; and (3) calculating a serles of ratios comparing water avallability in acre-feet with land avallability in acres for each water subbasin. This effort included an analysis of water data as well as USDA and U.S. Forest Service land ava11abllity information applicable to each subbasin.

\section{Task 4--Selected Subbasin Studies}

Task 4 required development of a set of criteria for ranking the energy farm potential for each of the 10 subbasins selected in Task 3 . A ranking procedure was established to rate each subbasin on economic, environmental, institutional, social, legal, and political factors. This procedure is described in Section VI. Section VI also contains analyses of the 10 high-potential study areas, includes a description of the major subbasin characteristics, and identifies major barriers to development and implementation of biomass farming in those subbasins.

A methodology that can be applied by others was developed and documented for evaluating future potential crop producing areas and sites. This methodology is described in Section VIII. 


\section{REFERENCES}

1. Stanford Research Institute, "Controlled Environment Agriculture," Long-Range Planning Report No. 526, Stanford Research Institute, Menlo Park, Callfornia (October 1974).

2. U.S. Water Resources Council, F1rst Natinnal Water Assessment (1968).

3. Second National Water Assessment (April 1978).

4. J.H. Ryther, "Cultivation of Macroscopic Marine Algae and Freshwater Aquatic Weeds;". Woods Hole Oceanographic Institute, Woods Hole, Massachusetts (1979).

5. Dynatech R/D . Company; Cost Analysis of Aquatic Biomass Systems, two volumes (July 25,1978 ).

6. See also studies by the California Institute of. Technology, the University of California at Berkeley, and Groton Blo-Industries Development Company, among others. 


\section{WATER AVAILABILITY ANALYSIS}

\section{Introduction}

The objective of task 1 was to estimate the amount of water avallable for energy projects in 1985 and 2000 in major U.S. water subbasins. . The subbasins were defined as the 99 Aggregated Subregions. (ASRs) within the contiguous. United States (see Figure III-1) that were identified by WRC. After reviewing pertinent studies and methodologies, we decided to rely heavily on work done by the WRC for their Second National Water Assessment. 1 This assessment provided detailed evaluations of streamflow, water use, and future trends for each subbasin. To supplement the WRC information, available ground water in each subbasin was determined.

- Estimates of water avallability vary considerably, depending on the assumptions used in the analysis. In this study, the SRI estimates are deliberately conservative and assume extreme drought conditions and preservation of some fish and wildlife values. The scope of the work did not include a reevaluation of streamflows and water withdrawais in every subbasin. Rather, SRI examined avallable data and concentrated on filling obvious data gaps. As a result, most of our effort was expended in evaluating WRC methodology and in estimating available ground-water supplies in each subbasir.

\section{The First and Second National Water Assessments}

The First National Water Assessment was completed in 1968 under the sponsorship of the WRC. * This study was the first attempt to assess the present and possible future status of water resources in the United States. since that Line, WRC has expanded analysis into three areas--nationwide analysis, specific problem analysis, and national problems. These studies have culminated in the series of draft reports comprising the Second National Water Assessment. 1 The WRC is now in the process of finalizing these reports, which are the only comprehensive reports that quantify water supplies and water withdrawals in all water basins in the United States.

Since 1973, many studies have been completed that identify water problems in the West and arcempt to quantify available water supplies in the face of growing energy demand. Some examples of these are: The

\footnotetext{
National assessments are conducted by the WRC to meet the requirements set forth in the Water Resourcee Planning Act of 1965 (P.L. 89-80).
} 


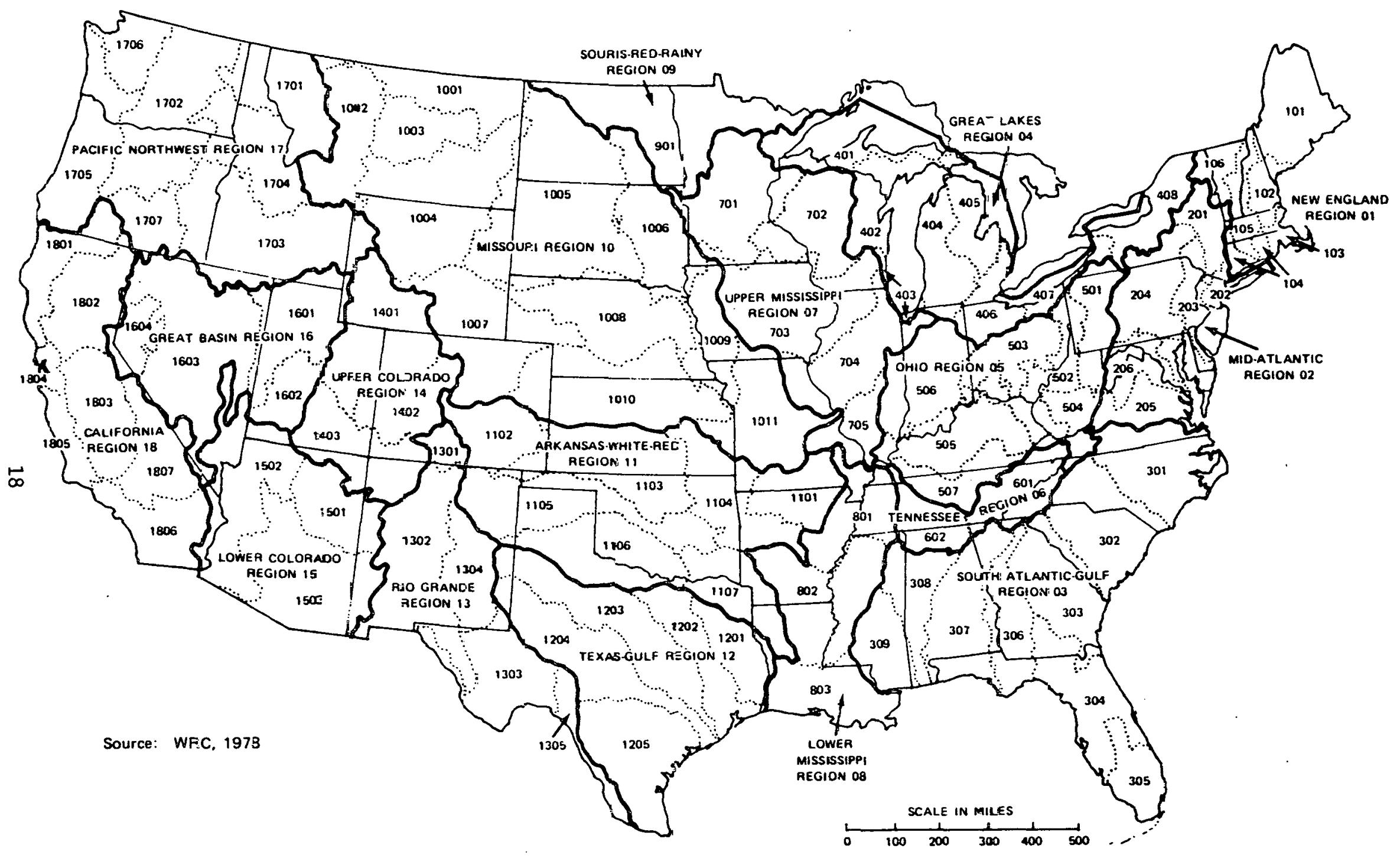

FIGURE III-1. LOCATION OF WATER RESOURCE SUBBASINS 
Westwide Study, ${ }^{2}$ the Northern Great Plains Resources Program, ${ }^{3}$ "Water for Energy," 4 and "Synthetic Liquid Fuels Nevelopment: Assessment of Critical Factors." 5 More recently, several national laboratorles, such as Oak Ridge National Laboratory and Lawrence Berkeley Laboratory, have been conducting similar studies to assess the availability of water for energy development in the West.

Al1'studies published since 1977 have relied on WRC data in estimating available water supplies. Before 1977, estimates for western states were based on in-house studies by the U.S. Bureau of Reclamation conducted around 1965.

The Second National Water Assessment was conducted to compile data on water resources and to evaluate the adequacy of water supplies necessary to meet future requirements in each of the 21 major water resource regions of the United States (including Alaska, Hawail, and Puerto Rico). The Second Assessment was based on a general analysis of the water balance in each of the 106 aggregated subregions, and it quantified, where possible, information on water quantity, water quality, consumptive use, recreational use, fish and wildlife use, and related land problems. Although the certainty of the data varies widely, depending on the type of data and the accuracy of the reporting source, the WRC assessment is the most comprehensive compilation of information useful for water resources planning and management.

The Second National Water Assessment relied on the technique of determining water balances to project available water supply (see Appendix A). This approach has several limitations. For example, because streamflow is given only at the outflow point of the subbasin, the analysis provides information only on the main stem of the river, not on any nf it.s tributaries. Consequently, the main stem could show an abundance of water even though several tributaries actually had serious water deficiencies. Conversely, the main stem could show an extremely low water supply even though several tributaries are known to have abundant supplies. In other words, it is impnssihle to obtain a clear idea of the distribution of water supply within each basin from this input-output analysis.

The consumption of water to meet society's needs has a significant effect on available water supply in certain river basins. Furthermore, projections of consumptive use will have a significant effect on future water planning and management. As shown in Figure III-2, agriculture is by far the largest consumer of water in the United States. Small gains in efficiency in agricultural water use could free a considerable amount of water for other uses. Recent trends indfcate that water conservation measures are being used increasingly in western states. Therefore, projections must account for such recent changes in water use patterns and avoid linear extrapolation of historical trends. The methodology used in the Second National Water Assessment assumed that patterns of water use in each sector were moving toward increased conservation. 


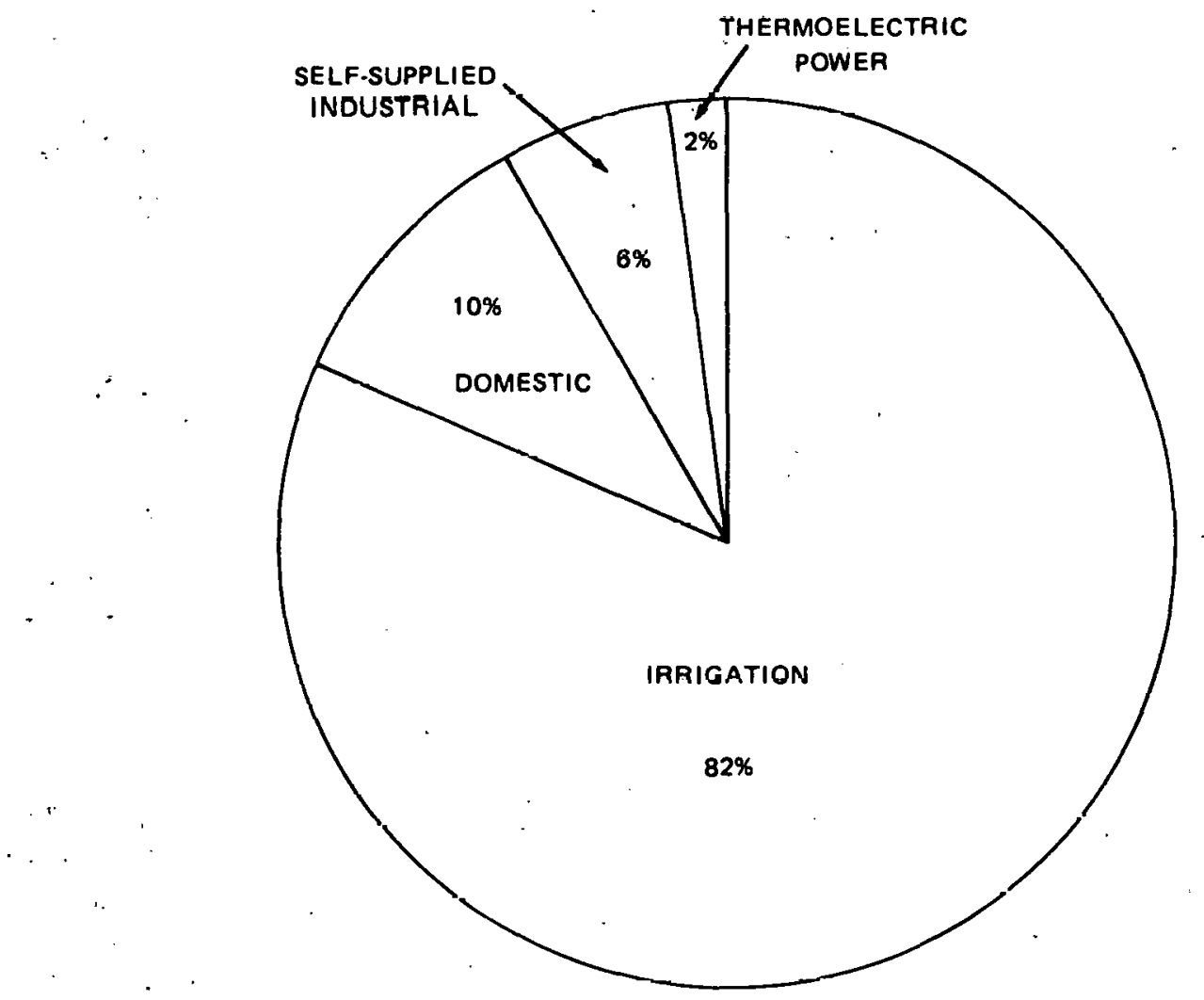

Source: Murray and Reeves, 1977

FIGURE III-2. WATER CONSUMED BY TYPE OF USE IN THE ${ }^{\prime}$ UNITED STATES, 1975 
In addition, the population and economic projections were based on OBERS Series $E$ of the Bureau of the Census, which assumes a birth rate that in time would yleld zero population growth exclusive of immigration. This rate approximates the birth rate experienced from 1970 to 1975 in this country.

The assumptions used in estimating current and future requirements for each water use sector are briefly summarized in Appendix A.

\section{SRI Study Approach}

Four steps were followed in developing estimates of water avallability for each subbasin in the contiguous United States: (1) preselection of basins for land avallability analysis; (2) evaluation of avallable data sources; (3) development of ground-water recharge estimates; and (4) development of high and low estimates of water avallability. A detailed explanation of each.step follows.

\section{Preselection of Basins for Land Availability Analysis}

The water availability analysis was conducted concurrently with the analysis of land availability for biomass farming. The determination of land availability required compilation of a vast amount of data on acreages of crops grown, return per acre, and economic tradeoffs among crops by county and state in each subbasin investigated. Consequently, to reduce the amount of time required to complete this task, SRI undertook a preselection process whereby a number of subbasins were eliminated from further consideration of land avallability.

Some river basins are known to have current water shortage problems. Preselection was based on the decision to eliminate subbasins in which current water consumption represents a large percentage of the available supply. After discussions with DOE, it was decided that subbasins should be eliminated from consideration if surface water consumption is more than 50 percent of surface-water supply. To obtain conservative estimates, we based our analysis on water supply and consumption during drought periods. The WRC reports contain estimates for normal years and for dry years. According to their definition, a dry year occurs when streamflows are at or below a level that is expected in only 20 out of 100 years. This is called the 80 percent exceedance level; that is, the streamflow that is equaled or exceeded 80 percent of the time. Normal streamflows are estimated at the 50 percent exceedance level.

Because the WRC data on water consumption by sector did not separate surface-water use from ground-water use, we were required to complete some additional calculations. The following equations were used:

$$
\text { Consumptive Use Ratio }(\%)=\frac{\text { Use }(s t)}{\text { Streamflow }+ \text { Use (st) }}
$$


where

Use $(s t)=$ Total Consumptive Use - Ground-water Use

This information was obtained from the WRC draft reports ${ }^{1}$ and permitted surface-water conditions to be evaluated separately from groundwater conditions. Consumptive use was added to the annual streamflow for each subbasin to reflect more accurately the amount of water avallable within the subbasin.

The results of this analysis are shown in Figure III-3. Note that In much of the southwest, consumption of surface water is equal to more than 50\% of the surface-water supply. Only in southern Florida (ASR 305) in the East and Chicago (ASR 403) in the Midwest are conditions similar. The 28 subbasins shown on Figure III-3 in which surface water use is equal to more than $50 \%$ of the surface water supply were ellminated from consideration in this study of land availability for biomass farms. Our later analysis of water supply by subbasin evaluated ground-water conditions in greater detail, and our estimate of the number of water-short subbasins increased as a result of this analysis (see results in this section and Appendix B).

Representative subbasins were then selected for analysis from those remaining. The subbasins selected had hydrologic and agricultural characteristics similar to those they represent (see Figure III-4). Thus, the number of subbasins to be studied in detail for the land availability analy3is was reduced to 21. Table III-1 slluws Llie selected subbastins and 71 similar subbasins that they represent. The results of the land availability analysis will be discussed in Section IV.

\section{Evaluation of Available Data Sources}

As previously discussed, the WRC study was found to be the most comprehensive one available. Estimates and projections were available by subbasin for consumptive and gross water use by sector, streamflow in nórmal and dry years, instream flow requirements for fish and wildlife, precipitation, runoff, drainage area, and additional factors. To provide a more complete assessment of available water supplies, we undertook to include additional ground-water data in the analysis. Where pnssible, this analysis was based on a series of U.S. Geological Survey (USGS) reports called "Summary Appraisals of the Nation's Ground-Water Resources."7-17 The next section discusses our evaluation of ground-water resources in detail.

\section{Development of Ground-Water Recharge Estimates}

Recent trends in regulating ground-water use in western states have focused on the concept of safe yield of aquifers, also known as steadystate or perennial yield. As defined by USGS, perennial yield of 


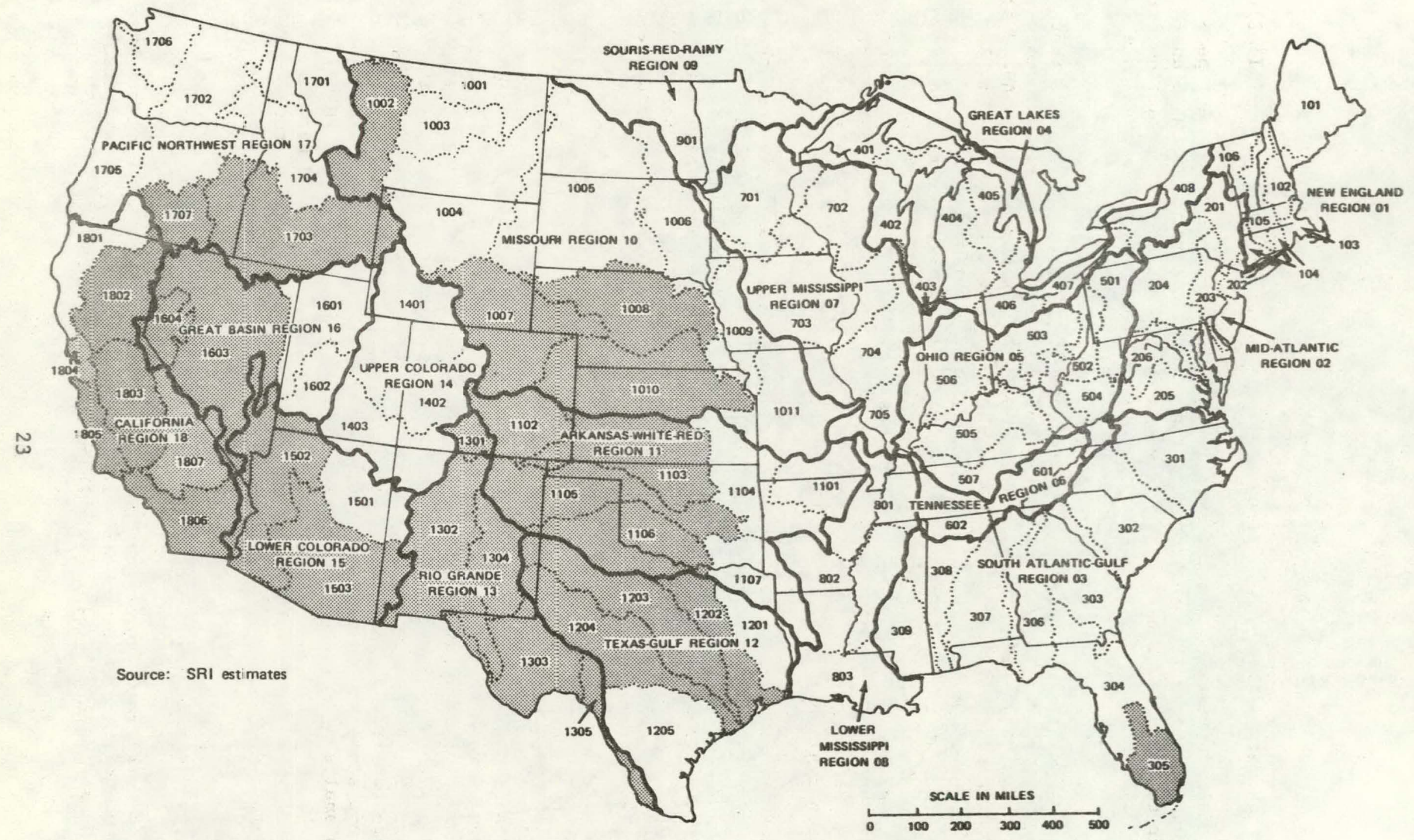

FIGURE III-3. CONS JMPTION JF SURFACE WATER MORE THAN 50\% OF SURFACE WATER SUPPLY - 2000 


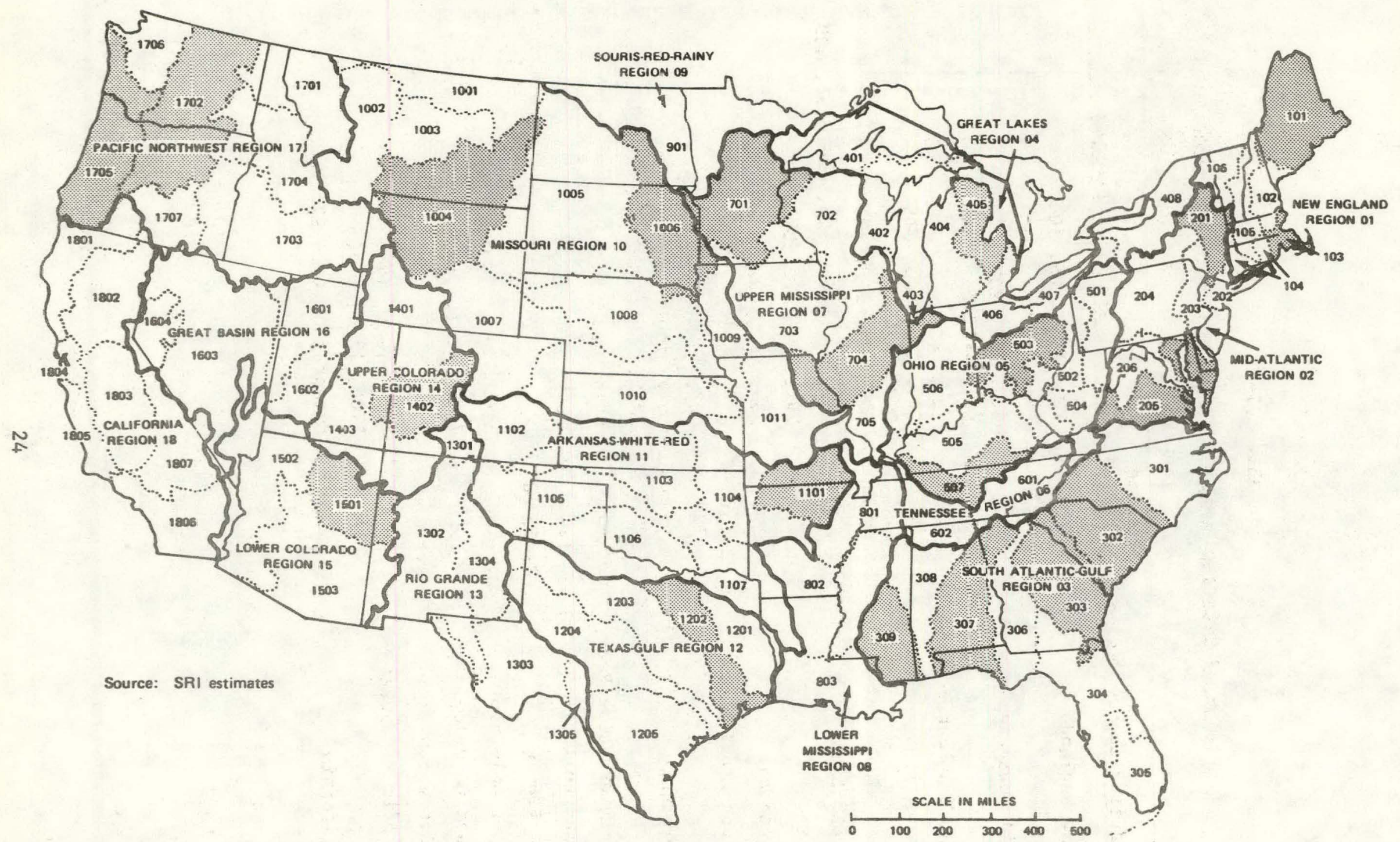

FIGURE III-4. BASINS SELECTED FOR DETAILED STUDY OF LAND AVAILABILITY 
Table III-1

LIST OF SELECTED SUBBASINS AND THOSE THEY REPRESENT

\begin{tabular}{|c|c|c|}
\hline Water Resource Region & $\begin{array}{l}\text { Selected } \\
\text { Subbasins }\end{array}$ & Similar Subbasins \\
\hline New England & $\begin{array}{l}101 \\
103\end{array}$ & $\begin{array}{l}101,102,105,106 \\
103,104\end{array}$ \\
\hline Mid-At1antic & $\begin{array}{l}201 \\
205\end{array}$ & $\begin{array}{l}201,202,203,204 \\
205,206\end{array}$ \\
\hline South Atlantic-Gulf & $\begin{array}{l}302 \\
303 \\
307 \\
309\end{array}$ & $\begin{array}{l}301,302 \\
303,304,305,306 \\
307,308 \\
309,801,802,803\end{array}$ \\
\hline Great Lakes & 405 & $401,402,404,405,406,407,408$ \\
\hline Ohio & 503 & $501,502,503,504,506$ \\
\hline Tennessee & 507 & $505,507,601,602$ \\
\hline Upper Mississippi & $\begin{array}{l}701 \\
704\end{array}$ & $\begin{array}{l}701,702,901 \\
703,704,705,1009\end{array}$ \\
\hline Missouri & $\begin{array}{l}1004 \\
1006\end{array}$ & $\begin{array}{l}1001,1003,1004 \\
1005,1006,1011\end{array}$ \\
\hline Arkansas-White-Red & 1101 & $1101,1104,1107$ \\
\hline Texas-Gulf & 1202 & $1201,1202,1205$ \\
\hline Rio Grande & Excluded & \\
\hline Upper Colorado & 1402 & $1401,1402,1403$ \\
\hline Lower Colusadu & 1501 & $1501,1601,1602$ \\
\hline Great Basin & Excluded & \\
\hline Pacific Northwest & $\begin{array}{l}1702 \\
1705\end{array}$ & $\begin{array}{l}1701,1702,1704 \\
1705,1706,1801\end{array}$ \\
\hline California & Excluded & Except 1801 (see 1705) \\
\hline
\end{tabular}


a ground-water reservoir is the maximum amount of water of a suitable chemical quality that can be withdrawn from the reservoir each year for an indefinite period of years without causing a continuous depletion of storage. The perennial yield cannot exceed the average annual natural recharge to, or discharge from, the reservoir. 12

For this study, we decided to use estimates of ground-water recharge or safe yield as measures of available ground-water supplies. This approach results in a conservative estimate because many aquifers have vast reserves of ground-water held in storage. However, several aquifers in the West, such as the Ogallala Aquifer in the Texas High Plains and the aquifers in the Rio Grande Basin, have become seriously overdrawn because of depletion of ground water in storage. On the other hand, if pumping is held to a quantity below the annual recharge rates, ground water is rarely drawn trom storage and permanent damage to the aquifer is avoided. Therefore, we are justified in taking this conservative approach to arrive at estimates of available water supplies for biomass farming.

USGS reports ${ }^{7-17}$ or Comprehensive Framework P1an Studies ${ }^{18-21}$ that provided some estimate of ground-water recharge were available for 12 of the 18 major water resource regions. For the six regions with no recharge data, we developed a method for predicting expected recharge rates based on a simple linear regression equation. Runoff in million gallons per day per square mile was plotted as a function of the ratio of recharge to runoff (in percent) on semilogarithmic paper. Two clear relationships emerged--one for regions that could be considered "wet" (annual precipitation greater than 10 inches) and one for regions that could be considered "dry" (annual precipitation less than 10 inches). The correlation coefficient for the equation for dry regions was 0.92 , whereas that for wet regions was much lower at 0.64 . This difference would seem to indicale that basin geology is a more important variable when precipication is high. The six regions estimated by this method were: New England, South Atlantic-Gulf, Lower Mississippi, Missouri, Arkansas-White-Red, and Lower Colorado. The results of the combined analysis by USGS and SRI are shown in Figure III-5. A breakdown by subbasin is given in Appendix B.

Development of High and Low Estimates of Water Availability

To obtain the most conservative estimates for water availability, streamflow in dry years was used as the basis for the projections. The WRC data for dry years assumed a very low streamflow--one that is equaled or exceeded in 80 out of 100 years ( 80 percent Exceedance Leve1). Streamflow at this level represents drought conditions.

The projections of streamflow at the outflow point of each subbasin in the Second National Assessment included a detailed analysis of consumptive use of water within each subbasin. We accepted these determinations for this study after review of the methodology (see Appendix A). Therefore, the WRC streamflow projections were used without alteration. 


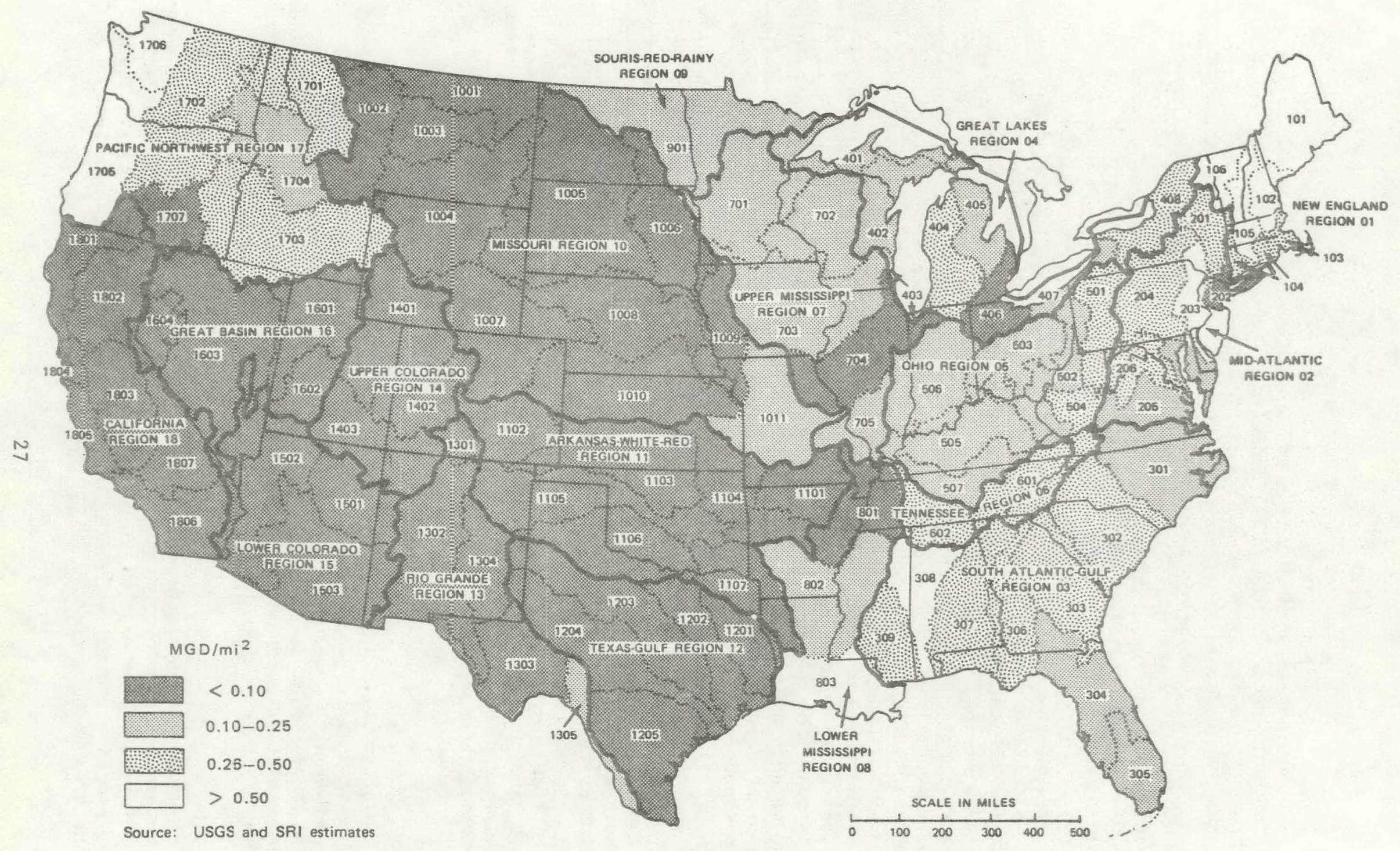

FIGURE III-5. ESTIMATED AVERAGE GROUND-WATER RECHARGE PER SQUARE MILE 
The WRC-estimated streamflows alone do not constitute a measure of the available water supply in each subbasin. Rather, a determination of what we have called "excess water supply" must include an assessment of how much water should be allowed to remain in the stream to maintain minimum streamflows for instream requirements. Instream flow requirements were estimated by the U.S. Fish and Wildlife Service (USFWS) for each subbasin and include the level of streamflow required to preserve fish and wildlife habitat and allow for hydropower generation, recreation, and navigation (see Appendix A for a discussion of their methods).

In many cases, the USFWS estimates accounted for huge volumes of water, somctimes exceeding tlie flow of the stream. Therefore, we decided to reduce the estimates by fixed percentages for incorporation into our analysis. We believe this is justified for scveral reasons. First, the water consumption and streamflow levels used in our analysis represent drought conditions. During a drought, reduced flows must be shared by all parties, including those requiring maintenance of instream flows. Second, and perhaps most important, instream flow requirements can only be determined by crude methods at present. Consequently, a large degree of uncertainty must be attached to the estimates. Finally, the estimates of instream flow requirements represent needs distributed throughout the subbasin, but the streamflow estimates represent the level at the outflow point. Therefore, the estimates can be reduced somewhat to correspond to an amount of water required at the outflow point of the subbasin.

The difference between our high and low estimate is directly related to the percentage of instream flow requirements applied to each. After thorough analysis of the effect of various levels of instream flow on the estimate of excess water supp1y for each subbasin, we decided to se1ert 80 percent for the low estimate and 50 percent for the high estimate. These percentages were applied as follows. The projected streamflow at the outflow point of the subbasin in year 2000 (for example) was taken as the base number. The USFWS estimate nf instream flow requircments fur that subbasin was multiplied by 0.80 and subtracted from the projected streamflow to obtain the low estimate. To obtain the high estimate, the USFWS estimate of instream flow requirements for that subbasin was multiplied by 0.50 and subtracted from the projected streamflow.

The final step in determining excess water supply was the addition of ground-water supply estimates. As a measure of annual ground-water availability, the estimates of ground-water recharge, or safe yield, in each subbasin were added to the tinal streamflow projections. The sum of these factors was the amount of excess water available for biomass farming or other uses.

\section{Water Availability Analysis Results}

The results for each water resource region are shown in Table III-2. A detailed breakdown by subbasin is found in Appendix B. Note that some regions are characterized by large variations in the excess water supply. 
Table III-2

SUMMARY OF ESTIMATED EXCESS WATER SUPPLY BY MAJOR RIVER BASIN--1985 AND 2000

(Drainage Area in Thousands of Square Miles; Other Figures in Thousands of Millions of Gallons per Day per Square Mile)

\begin{tabular}{|c|c|c|c|c|c|c|c|c|c|c|c|c|}
\hline & & Drainage & 1915 & $\begin{array}{l}\text { Ground- } \\
\text { Water }\end{array}$ & & $\begin{array}{r}198 \\
\text { cess }\end{array}$ & pply & & & $\begin{array}{r}200 \\
\text { cess S }\end{array}$ & pply & \\
\hline & River Basin & Area & Streamflow & Recharge & Hig & & Low & & High & & Lon & \\
\hline 100 & New England & 71.9 & 62.7 & 40.8 & 68.8 & 0.96 & 48.2 & 0.67 & 68.2 & 0.95 & 47.7 & 0.66 \\
\hline 200 & Mid-Atlantic & 117.6 & 70.4 & 38.6 & 68.5 & 0.58 & 44.5 & 0.38 & 67.1 & 0.57 & 43.1 & 0.37 \\
\hline 300 & South Atlantic-Gulf & 277.3 & 164.1 & 89.8 & 157.3 & 0.57 & 100.7 & 0.36 & 153.9 & 0.55 & 97.3 & 0.35 \\
\hline 400 & Great Lakes & 113.6 & 57.3 & 25.9 & 50.5 & 0.44 & 31.3 & 0.28 & 49.2 & 0.43 & 30.0 & 0.26 \\
\hline 500 & Ohio & 162.7 & 257.8 & 35.4 & 148.5 & 0.91 & 62.8 & 0.39 & 144.6 & 0.89 & 58.9 & 0.36 \\
\hline 600 & Tennessee & 40.8 & 55.2 & 20.4 & 45.0 & 1.10 & 26.9 & 0.66 & 44.3 & 1.09 & 26.2 & 0.64 \\
\hline 700 & Upper Mississippi & 190.1 & $=98.4$ & 23.3 & 93.3 & 0.49 & 23.8 & 0.13 & 88.6 & 0.47 & 21.8 & 0.11 \\
\hline 800 & Lower Mississippi & 103.5 & 761.0 & 25.9 & 258.9 & 2.50 & 0.0 & 0.0 & 241.6 & 2.33 & 0.0 & 0.0 \\
\hline 900 & Souris-Red-Rainy & 59.4 & 3.4 & 10.0 & 11.5 & 0.19 & 10.4 & 0.18 & 11.8 & 0.20 & 10.7 & 0.18 \\
\hline 1000 & Missouri & 511.4 & 99.3 & 17.9 & 35.0 & 0.07 & 5.0 & 0.0 & 28.6 & 0.06 & 3.7 & 0.01 \\
\hline 1100 & Arkansas-White-Red & 247.6 & 42.5 & 3.4 & 10.8 & 0.04 & 0.7 & 0.0 & 10.7 & 0.04 & 0.8 & 0.0 \\
\hline 1200 & Texas & 181.5 & 12.3 & 4.2 & 2.5 & 0.01 & 0.0 & 0.0 & 2.1 & 0.01 & 0.1 & 0.0 \\
\hline 1300 & Rio Grande & 132.8 & 0.9 & 3.6 & 0.6 & 0.0 & 0.5 & 0.0 & 0.6 & 0.0 & 0.5 & 0.0 \\
\hline 1400 & Upper Colorado & 113.3 & 13.1 & 3.6 & 8.3 & 0.07 & 3.9 & 0.03 & 7.7 & 0.07 & 3.3 & 0.03 \\
\hline 1500 & Lower Colorado & 140.5 & 1.6 & 3.0 & 0.5 & 0.0 & 0.4 & 0.0 & 0.4 & 0.0 & 0.4 & 0.0 \\
\hline 1600 & Great Basin & 142.1 & 6.7 & 2.9 & 5.0 & 0.04 & 2.9 & 0.02 & 4.9 & 0.03 & 2.9 & 0.02 \\
\hline 1700 & Pacific Northwest & 277.3 & 371.3 & 98.5 & 283.3 & 1.02 & 177.4 & 0.64 & 282.6 & 1.02 & 176.6 & 0.64 \\
\hline 1800 & California & 176.5 & 30.4 & 4.9 & 15.3 & 0.09 & 6.6 & 0.04 & 14.0 & 0.08 & 6.2 & 0.04 \\
\hline U. & S. Total & $3,059.9$ & $2,208.4$ & 452.1 & $1,263.6$ & 0.41 & 546.0 & 0.18 & $1,220.9$ & 0.40 & 530.2 & 0.17 \\
\hline
\end{tabular}


In those regions, instream flow requirements are large by comparison with the projected streamflow. If the low estimate is used, we project that 31 subbasins will have no excess water in 1985, and 36 will have none in 2000. If the high estimate is used, water supplies are projected to be tight in 13 subbasins in 1985 and 2000 .

The high and low estimates of excess water supply in each subbasin in the year 2000 are presented in Figures III-6 and III-7. For the high estimate, 6 subbasins are estimated to have an excess supply of more than 50,000 million gallons per day, and 12 subbasins to have zero excess supply. For the low estimate only 1 subbasin is estimated to have an excess supply of more than 50,000 million gallons per day, and 35 subbasins to have zero excess supply.

Because the sizes of the drainage basins differ markedly, the estimates given in Figures III- 6 and III-7 provide a somewhat biased view of the excess water supply. To compare the subbasins properly, the water supp1y was divided by the drainage area in square miles to provide an estimate of excess water supply per square mile of surface area. Another way to think of this number is as the yield of the basin. The results of this assessment are shown in Figures III-8 and III-9. In Figure III-8 (high estimate), 20 subbasins yield more than 1.0 million gallons per day per square mile, and 10 subbasins yield 0.0 million gallons per day per square mile. Note that much of the Southeast falls into a lower category when size of the drainage area is considered. For the same reason, the small basins in the Northeast move to a higher category because their yield per unit area is quite high compared with that of other areas.

In summary, the difference between the high and low estimates of excess water supply is substantial in subhasins where instream flow requirements represent a high percentage of the projected streamflow. The estimates given here are conservative and provide a reasonable assessment of excess ground-water and surface-water supply during low flow or drought years. The next section discusses some of the limitations inliesent in the data.

\section{Limitations of the Data}

Many factors affect the availability of water in a liver basln. These include: hydrologic factors, such as precipitation, runoff, and evapotranspiration; water use factors, such as population, economic conditions, and types of manufacturing; biologic factors, such as pollution inflow, habitat conditions, and instream flow requirements; and legal/ institutional factors, such as treaties and compacts, pollutant discharge requirements, transferability of water rights, and federal reserved rights. Unfortunately, data that allow a quantitative assessment of many of these factors are often unavailable. Thus, uncertainty is inherent in any estimate of excess water supply. 


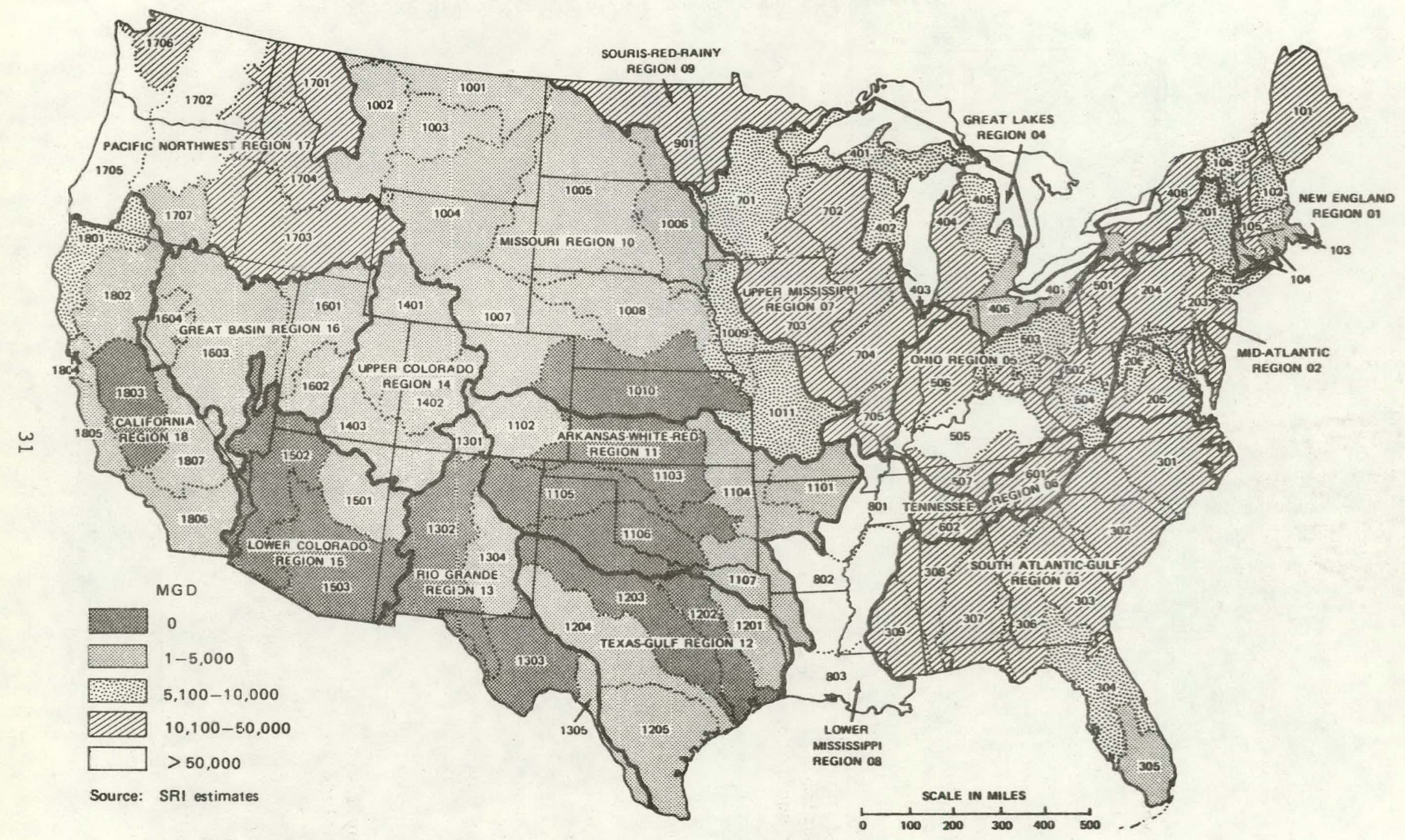

FIGURE III-6. EXCESS WATER SUPPLY - 2000, HIGH ESTIMATE 


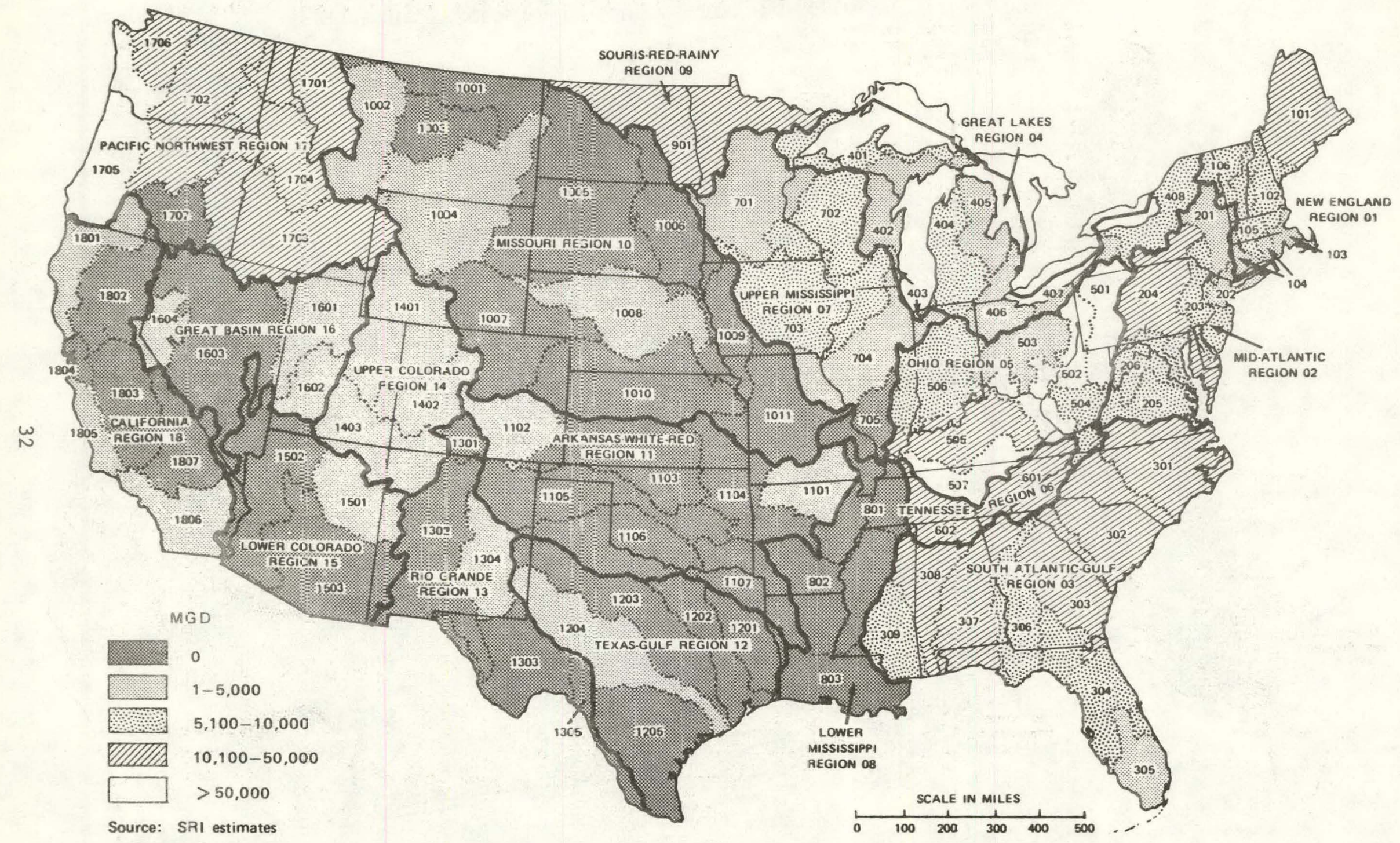

FIG JRE III-7. EXCESS WATER SUPPLY - 2000, LOW ESTIMATE 


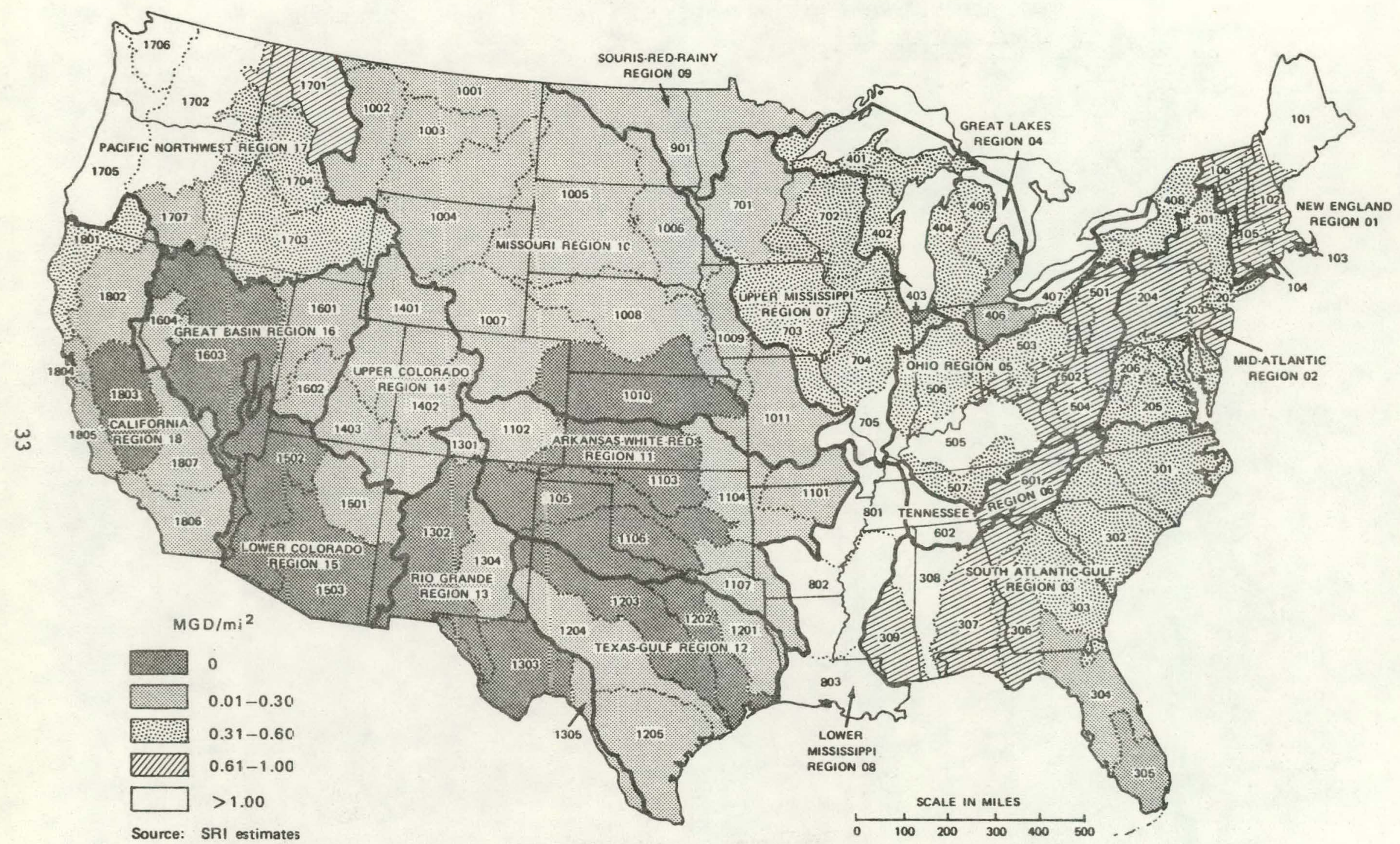

FIGURE III-8. EXCESS WATER SUPPLY PER SQUARE MILE OF SURFACE AREA - 2000 HIGH ESTIMATE 


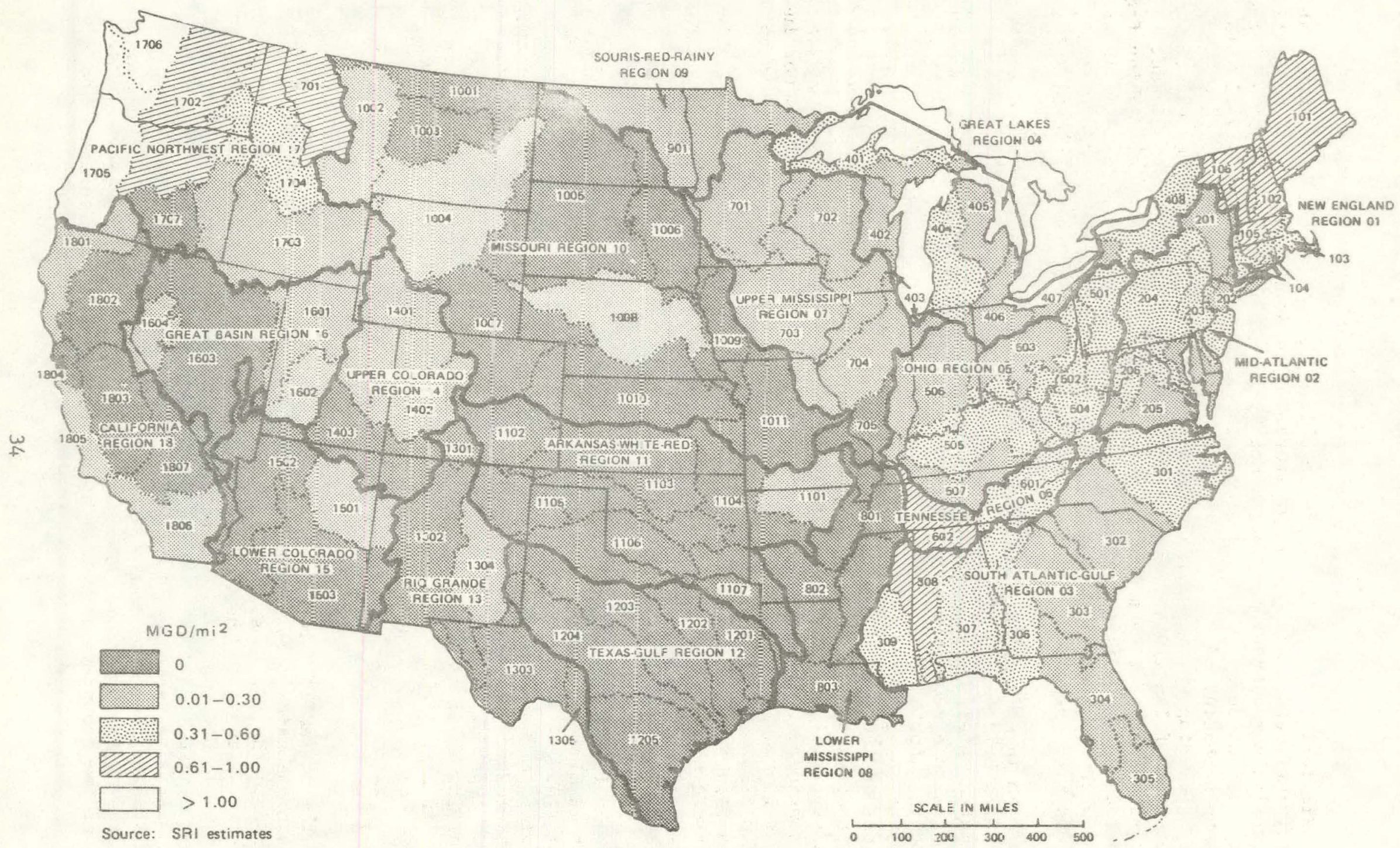

FIGURE III-9. EXCESS WATER SUPJLY PER SQUARE MILE OF SURFACE AREA - 2000 LCW ESTIMATE 
Similarly, the estimates in this document are subject to considerable uncertainty, and caution must be exercised in making use of the projections. Generally, our approach was satisfactory for meeting the objective of the study, but it does not supply a definitive assessment of avallable water in each subbasin. To provide such an assessment, a detalled hydrologic study including water quality modeling, socloeconomic projections, and assessment of legal/institutional requirements would be necessary for each subbasin. For this study, water was only one of several ranking factors that allowed differentlation among subbasins and a determination of those with the greatest potential for blomass farming. In this context, our estimates provide a reasonable representation of the available data.

Even in this context, however, the shortcomings in our approach warrant a brief discussion. The projections of the WRC were based on the estimated water balance in each subbasin (see Appendix A). Inputs to the water balance were interbasin imports, mined ground water, and precipitation. Outputs were interbasin exports, evaporation; and water consumption. Although compacts were reviewed, the associated quantity of water was not included in the water balance unless it resulted in an interbasin import or export of water. The fact that many compacts simply require water to remain in the stream and flow to the next basin downstream was not considered. The storage capacity of lakes and reservoirs was not included in the water balance, and, in fact, should not be included except in low flow periods when available storage can make up the deficit in streamflow. Therefore, our use of projected streamflows during drought years did not consider the potential supply from lakes or storage reservoirs and caused our estimates to be lower than might otherwise be estimated in some cases.

The limitations related to the failure to consider lakes and reservoirs were most apparent in the Great Lakes Basin. There, estimates of ctreamflow only included what flnwed into the lakes. The vast storage potential of the Great Lakes system was not considered. However, if one is interested only in the "safe yield" for a water basin, this is the proper approach. Storage should only be used when natural rainfall or streamflow falls below normal. During those times, storage can be drawn upon and then replenished during years of high rainfall. On the other hand, the Great Lakes could probably be subjected to substantial withdrawals without adverse effects on the lake ecosystem or on navigation. We did not attempt to estimate this potential supply.

The streamflow projections of the WRC were made at the outflow point uf each sublasin. The distribution of water within each subbasin did not enter into the analysis. As a result, some subbasins with an abundance of water at their mouths could have tributaries that suffer from severe shortages. Likewise, tributaries could have an abundance of water, even though conditions at the outflow point indicate a severe shortage.

Finally, our estimates of ground-water supply assumed that annual recharge to the aquifers was entirely available for withdrawal. In fact, some of the ground-water recharge eventually enters the stream through 
base flow and maintains streamflow levels during dry summer months. It is not possible to predict where or how significant the effect of groundwater pumping at the level considered to represent safe yield will be. A more thorough understanding of basin geology, the interconnection between alluvial and deep underground aquifers, and the interaction between. surface water and ground water is required to improve these estimates. 


\section{REFERENCES}

1. U.S. Water Resources Council, "The Nation's Water Resources, The Second National Water Assessment by the U.S. Water Resources Council, Parts I-V, Appendices A and B," Washington, D.C., draft report (Apri1 1978).

2. U.S. Department of the Interior, "Critical Water Problems Facing the Eleven Western States," Westwide Study Report (April 1975).

3. Northern Great P1ains Resources Program, "Effects of Coal Development in the Northern Great Plains," Denver, Colorado (April 1975).

4. U.S. Department of the Interior, "Report on Water for Energy in the Upper Colorado River Basin," Water for Energy Management Team (July 1974).

5. E.M. Dickson et al, "Synthetic Liquid Fuels Development: Assessment of Critical Factors," Report to the Energy Research and Development Administration, Report No. ERDA 76-129/3, SRI International, Menlo Park, California (May 1977).

6. C.R. Murray and E. Reeves, "Estimated Water Use in the United States in 1975," U.S. Geological Survey, Circular 765 (1977).

7. E.T. Baker, Jr., and J.R. Wa1l, "Summary Appraisals of the Nation's Ground Water Resources--Texas-Gulf Region," U.S. Geological Survey Professional Paper 813-F (1976).

8. M.S. Bedinger and R.T. Sniegock1, "Summary Appraisals of the Nation's Ground Water Resources--Arkansas--White-Red Reg1on," U.S. Geologieal Survey Professional Paper 813-H (1976).

9. R.M. Bloyd, Jr., "Summary Appraisals of the Nation's Ground Water Resources--Ohio Region," U.S. Geological Survey Professional Paper 813-A (1974).

10. R.M. Bloyd, Jr., "Summary Appraisals of the Nation's Ground Water Resources--Upper Mississippi Region," U.S. Geological Survey Professional Paper 813-B (1975).

11. T.E. Eakin, D. Price, and J.R. Harr111, "Summary Appraisals of the Nation's Ground Water Resources--Great Basin Region," U.S. Geological Survey Professional Paper 813-G (1976). 
12. D. Price and T. Arnow, "Summary Appralsals of the Nation's Ground Water Resources--Upper Colorado Region," U.S. Geological Survey Professional Paper 813-C (1974).

13. H.0. Reeder, "Summary Appra1sals of the Nation's Ground Water Resources--Sour1s-Red-Rainy Region," U.S. Geological Survey Professional Paper 813-K (1978).

14. A. Sinnott and E. M. Cushing, "Summary Appraisals of the Nation's Ground Water Resources--Mid-Atlantic Region," U.S. Geological Survey Professional Paper 813-I (1978).

15. H.E. Thomas and D.A. Phoen1x, "Summary Appra1sals of the Nation's Ground Water Resources--California Reglon," U.S. Geological Survey Professlonal Paper 813-E (1976).

16. S.W. West and W.L. Broadhurst, "Summary Appraisals of the Nation's Ground Water Resources--Rio Grande Reg1on," U.S. Geological Survey Professional Paper 813-D (1975).

17. A. Zurawsk1, "Summary Appraisals of the Nation's Ground Water Resources--Tennessee Region," U.S. Geological Survey Professional Paper 813-L (1978).

18. Great Lakes Basin Commission, "Great Lakes. Basin Framework Study-Appendix 3, Geology and Ground Water," Ann Arbor, Michigan (1975).

19. Missouri Basin Inter-Agency Committee, "Comprehensive Framework Study--Appendix, Hydrologic Analyses and Projections," U.S. Government Printing office, Washington, D.C. (June 1969).

20. Pacific Northwest River Basins Commission, "Columbia-North Pacific Region Comprehensive Framework Study, Appendix V, Water Resources," Vancouver, Washington (April 1970).

21. U.S. Geological Survey, "North Atlantic Reglonal. Water Resources Scudy, Appendix D--Geology and Ground Water," North Atlantic Water Resources Study Conrdinating Committeo (March 1971). 


\section{BIBLIOGRAPHY}

$$
\text { (6): }
$$

California Department of Water Resources, "The California Water Plan-Outlook in 1974," Bulletin No. 160-74, Sacramento, California (November 1974).

McGuinness, C.L., "The Role of Groundwater in the National Water Situation," U.S. Geological Survey Water Supply Paper 1800 (1963). 
THIS PAGE

\section{WAS INTENTIONALLY LEFT BLANK}




\section{LAND AVAILABILITY}

\section{Introduction}

Increasing energy consumption in industrialized nations is rapidly depleting the world's coal, petroleum, and natural gas resources. Within the next 25 years, more than one-half the proven resources of petroleum and natural gas is expected to be consumed. 1 Despite the vast coal reserves, severe economic and environmental problems constrain the use of this energy source as well as other forms of fossil fuels, such as those found in oil shales.

To meet the rising demand for energy, other possible sources are under investigation. This section of the report presents an economic and physical analysis of biomass-organic materials generated by photosynthesis--as an alternative source of energy.

\section{Objectives and Scope}

The purpose of this analysis was to determine the amount of acreage potentially available for biomass production in 71 subbasins for the years 1985 and $2000 .^{*}$ The analysis was performed in six tasks with the following specific objectives:

- Quantify and categorize the total land area in each of the subbasins.

- Select 21 representative subbasins (with adequate water supply) for further analysis.

- Estimate an average annual net return in 1985 and 2000 for conventional agricultural and forest production.

- Estimate an average annual net return in 1985 and 2000 for three primary categories of biomass operations:

- A food (fiber)/fuel combination from which the food (fiber) component of conventional crops is used for traditional purposes and the agricultural or forestry residues are used as a fuel source

- A fuel-only use in which the entire crop or tree is used as an energy feedstock

These suhhasins-WRC. Aggregated Subregions--are designated in Section III, "Watèr Avãilability." 
- The cultivation of high-yielding specialty crops or trees specifically for conversion to fuels.

- Determine the amount of acreage potentially available for biomass production from the date developed in the task above.

- Determine the impact on acreage availability of a change in the price per dry ton for biomass.

The analysis was confined to consideration of land capability Classes I through IV of the cight classca identified in the 1967 USD S Soil Conservation Service report, "National Inventory of Soli and Water Conservation Needs." $2 *$. These four land capability classes wcre examined in relation to three major common land-use catëgorlés and rëlevant subcategories, as follows:

- Cropland

- Row crops

- Close-grown crops

- Hayland

- Orchards

- Summer fallow

- Temporarily idle cropland

- Rotation hay and pasture

- Upen land formerly cropped

- Rangeland

- Pastureland

- Rangeland

- Forest land

- Commercial: grazed, ungrazed

- Noncommercial: grazed.

The analysis was based on two assumptions. First, major shifts will not occur during the 1985 and 2000 time frame of the analysis in the amount of acreage within either land capability classes or land-use categories. Second, if the net return from a biomass enterprise exceeds that from conventional agriculture, that acreage would be considered potentially available for biomass production. Exceptions to this assumption were made for, cases which the most desirable biomass net return was negative but numerically less negative than the conventional net return.

* An update of this study is being prepared, but was unavailable at the time of this writing. 
In such a situation, the best biomass option does not generate a positive return; it merely provides a means of reducing the losses that would result from use of the land for conventional agriculture. Such areas were not assumed to be available for biomass production. Questions of the possible effects on supply and price of the transfer of land currently cropped for food (fiber) to biomass production and of subsequent income effects were considered outside the scope of this analysis.

\section{General Methodology}

The selection of the 21 representative subbasins was made on the basis of established agricultural and hydrological criteria. For each of these subbasins, an average annual net return was developed for the 13 subcategories of the three major land-use categories and the four land capability classes. Yields per acre, associated production costs, and prices to be paid were estimated for conventional agricultural and forest production for the years 1985 and 2000. (See Appendix C for the technical details of the development of net returns for conventional crop production.) An average net return was generated next for the three primary categories (listed above) of biomass operations. Within these categories, 13 biomass production options were identified. Net returns for each option for both 1985 and 2000 were completed and organized by using the methodology, data, and land classification criteria applied for the conventional agricultural and forest net returns; when necessary, supplementary data were also used. (See Appendix $C$ for technical details of the development of net returns for biomass production.)

Prices for biomass feedstocks were determined by comparing the prices for biomass-derived fuels with those from conventional sources. 3 A price of $\$ 20.50$ (fourth-quarter 1977 dollars) per dry ton was used for the 1985 estimates and $\$ 27.50$ per dry ton for the year 2000 for all biomass feedstocks. A set of 72 net return comparisons was developed to determine the amount of acreage potentially available for biomass production. This process was repeated for all 71 subbasins in the four land capability classes fur the years 1985 and 2000. (See Appendix C for the technical details of the comparison of conventional crop and biomass net returns.)

\section{Land Inventory}

Data from the 1967 Soil Conservation Servjce "National. Inventory of Soil and Water Conservation Needs"2 were $2 \ldots 1 \ldots$ prepare a $a^{\prime}$ trix $c_{\text {. }}$. total land area in each of the 71 subbasins the. could potentially support a biomass crop. (A similar matrix was prepiied for net returns for conventional crops and the food (flber)/fuel and fuel-only biomass operations.) The matrix (see Table IV-1) was based on two criteria: the land capability classes and current land use.* Arable soils in the land

\footnotetext{
* See the soil Conservation Service report for complctc definitions uf lhe land capability classes and land-use types. ${ }^{2}$
} 
Table IV-1

LAND INVENTORY MATRIX FOR CONVENTIONAL CROPLAND COMMODITIES, RANGELAND, AND FOREST LAND IN 71 SÜBBASINS

(Thousands of Acres)

\begin{tabular}{|c|c|c|c|c|c|}
\hline \multirow{2}{*}{$\begin{array}{c}\text { Land-Use Categories } \\
\text { and Subcategories } \\
\end{array}$} & \multicolumn{5}{|c|}{ Land Capability Class } \\
\hline & $\mathrm{I}$ & II & III & IV & Tota1 \\
\hline \multicolumn{6}{|l|}{ Cropland } \\
\hline Row crop & 15,696 & 64,893 & 33,930 & 7,588 & 122,107 \\
\hline Glese=grown srop & 2,616 & 30,770 & 20,670 & 5.693 & 59,749 \\
\hline Hayland & 679 & 6,547 & 7,275 & 4,162 & 18,663 \\
\hline Orchards & 134 & 842 & 1,202 & 628 & 2,806 \\
\hline Summer fallow & 54 & 6,743 & 6,709 & 1,728 & 15,234 \\
\hline Temporarily idle cropland & 440 & 3,308 & 2,767 & 1,210 & 7,725 \\
\hline Rotation hay and pasture & 2,262 & 18,107 & 13,888 & $.5,388$ & 39,645 \\
\hline Open land formerly cropped & 236 & 2,557 & 3,254 & 2,031 & 8,078 \\
\hline \multicolumn{6}{|l|}{ Rangeland } \\
\hline Pastureland & 3,042 & 21,880 & 25.612 & 16,499 & 67,033 \\
\hline Rangeland & 457 & 12,430 & 24,813 & 21,370 & 59,070 \\
\hline \multicolumn{6}{|l|}{ Forest land } \\
\hline \multicolumn{6}{|l|}{ Commercial } \\
\hline Grazed & 897 & 0,095 & 14,681 & $13 ; 215$ & 37,688 \\
\hline Ungrazed & 2,570 & 34,380 & 54,593 & 45,304 & 136,847 \\
\hline \multicolumn{6}{|l|}{ Noncommercial } \\
\hline Grazed & 47 & 688 & 975 & 977. & 2,687 \\
\hline Total land area & 29,130 & 212,040 & 210,369 & 125,793 & 577,332 \\
\hline
\end{tabular}


capability classes are grouped according to their potential and 1 imitations for sustained production of the common cultivated crops not requiring specialized site conditioning or treatment.

The Soll Conservation Service identified elght capability classes. The risks of soll damage or limitations in use become progressively greater from Class I to Class VIII. With efflcient management, solls in Classes I through IV can produce adapted plants, such as forest trees, range plants, and the common cultivated fleld crops and pasture plants. Solls in Classes V, VI, and VII are capable of producing adapted native plants. Some soils in Classes $V$ and VI can also produce specialized crops, such as certain fruits and ornamentals and field and vegetable crops; however, production in these classes requires highly intensive land management that includes elaborate practices for soil and water conservation with attendant additional high costs. Soils in Class VIII do not support crops, grasses, or trees unless major reclamation is undertaken. Because of these limitations, this analysis is restricted to land capacity Classes I through IV.

Each land capability class contains subclasses characterized by the same dominant soil and climate limitations for agricultural use. For example, some soils are subject to erosion, whereas others are naturally wet and must be drained to support crop production. Conversely, other soils are shallow or droughty, and the climate limits the use of soils in some areas. All the subclasses in land capability Classes I through IV are included in the land inventory matrix.

The Soil Conservation Service report ${ }^{2}$ identifies 17 distinct landuse types; these are the second criterion used to structure the land inventory matrix. Several land-use types were eliminated from the analysis because they lacked the potential to support a blomass crop. For example, Land allocated to conservation purposes, ungrazed noncommercial forest land, and certain other land (e.g., feedlots, coastal dunes) were excluded from consideration. (See Table IV-1, for a 1 ist of the land-use types included in the analysis.)

Average Annual Net Return: Conventiona1 Agriculture and Forest Production

Estimating the average annual net return from conventional crop and forest production for each land-use type in the selected subbasins required the identification and calculation of an average annual net return for each commodity in each land-use type. To accomplish this, a general methodology (see Appendix C) was designed for application to all commodities. Analyses of the three land-use categories in each of the 21 subbasins are presented in the subsections that follow.

Cropland

Four of the subcaregories of cropland llses were included in this analysis. These are: row crops, close-grown crops, hay, and orchards. 
The land-use subcategorles (see Table IV-1) not included here are assumed to have no net return. The principal cropland commodities identifled in each subcategory are listed in Table IV-2.

Table IV-2

CLASSIFICATION OF CONVENTIONAL CROPLAND COMMODITIES

\begin{tabular}{|c|c|c|c|}
\hline Row Crops & $\begin{array}{c}\text { Close-Grown } \\
\text { Crops }\end{array}$ & Hay & Orchards \\
\hline Curin & Wheat & MItialta & citrus \\
\hline Corn silage & Oats & & Noncitrus \\
\hline Soybeans & Barley & & \\
\hline Sorghum (grain) & Rye & - & \\
\hline Peanuts & Rice & r & \\
\hline
\end{tabular}

Sugarcane

Sugar beets

Potatoes

Sources: Reference 4; SRI International

Yields. To estimate the yields per acre for each of the commodities In Table IV-2 in the four land classes for the years 1985 and 2000 , the average yields per acre for each were obtained from USDA and sLaLe dul county extension services projections. These projection dala were supplemonted with a detailed produrtivity index that is commodity-specific for each land capability class and subclass in the 21 subbasins selected for analysis. 5 (A1thnugh this index was prepared in 1976, relative productivity across land classes is assumed to be unaltered for the time period of this analysis.) Examples are in Tables $\overline{I V}-3$ and IV $=4$.

Prices. Estimates of prices in 1985 and 2000 prepared by the USDA Economic Research Service are national averages and do not take into arcount regional disparities. ${ }^{6}$ These price projections assume that the major influences on supply and demand will have moderate rates of growth and that inflation in the general economy will average 5 percent per year.

In estimating demand, USDA made the following assumptions. Gross national product (GNP) will grow at 3 percent per year, and population 
Tab1e IV-3

YIELDS OF : CONVENTIONAL CROPLAND COMMODITIES IN 1985-SUBBASIN 206

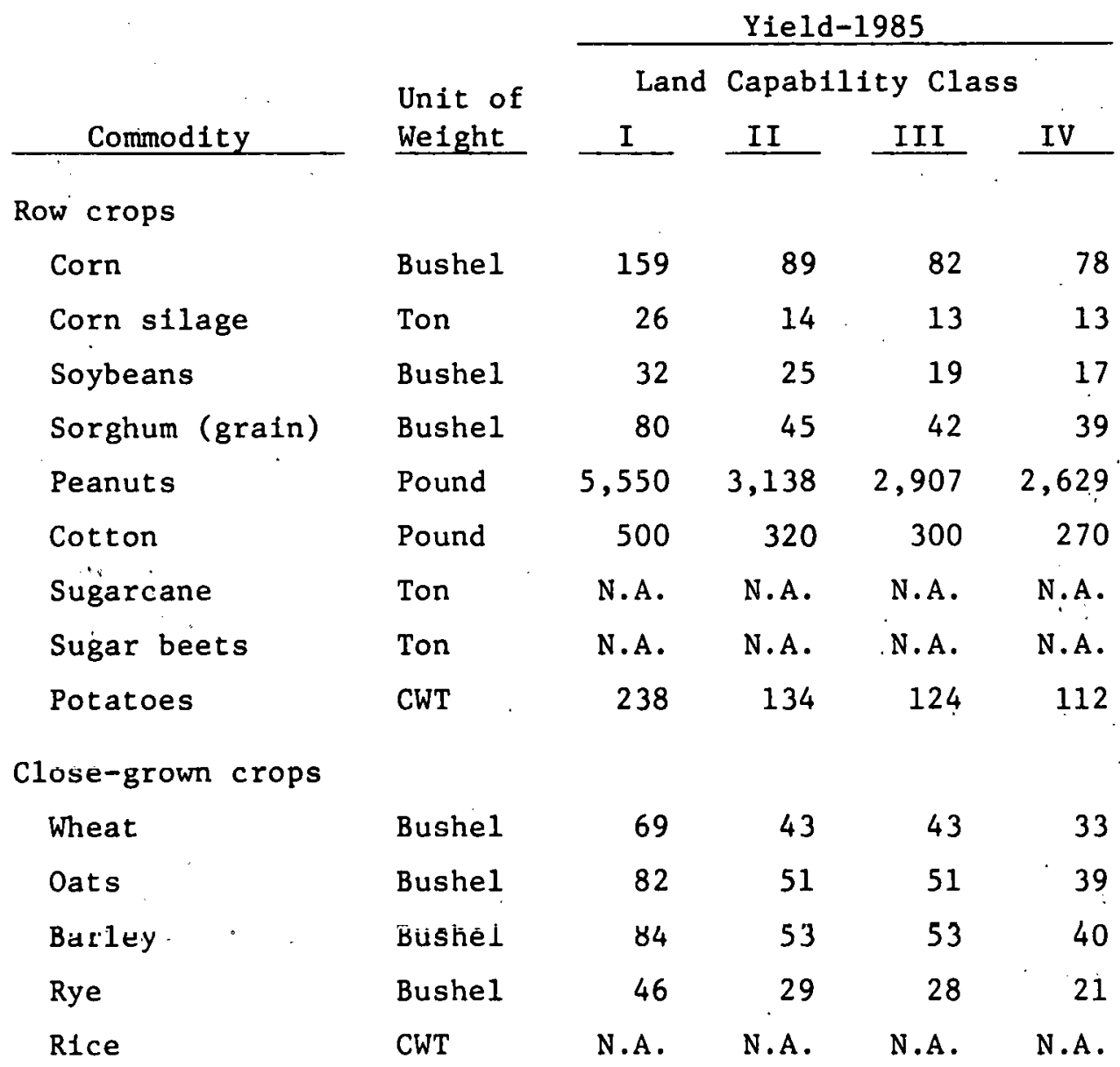

Hay

$\begin{array}{llllll}\text { Alfalfa } & \text { Ton } & 4 & 2 & 1 & 1\end{array}$

Orchards

$\begin{array}{lrrrrr}\text { Citrus fruits } & \text { Ton } & \text { N.A. } & \text { N.A. } & \text { N.A. } & \text { N.A. } \\ \text { Noncitrus fruits } & \text { Ton } & 10 & 5 & 5 & 4\end{array}$

N.A. $=$ Not Appl1cable 
Table IV-4

CONVENTIONAL CROPLAND COMMODITIES IN 2000--

SUBBASIN 206

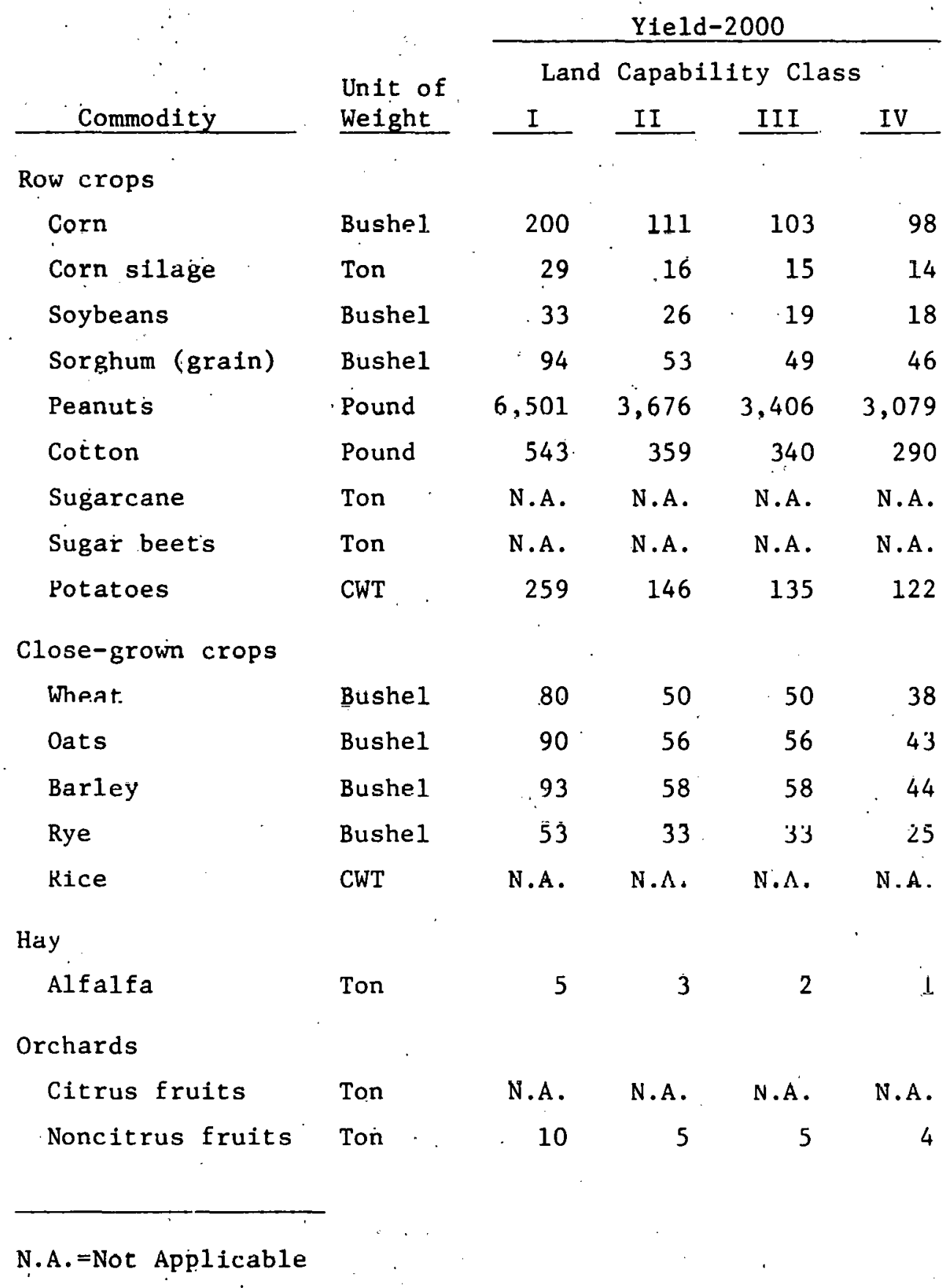


will grow in accordance with the Búreau of Census Series II projections. Taste-and preference aspects will lead to no significant additional substilution of plant protein for red meats. Modified historical trends in economic development and in agricultural and world trade policies are assumed to continue; thus, agricultural trade conditions will foster moderate exports. Several national trade policies to promote selfsufficiency constrain international trade, but not all trade-restrictive goals will be met. Eastern Europe and the USSR will continue to import moderate amounts of feed grains and soybeans, and the People's Republic of China (PRC) will continue to import wheat and export rice.' In developing countries, food production will continue to slightly outpace growth in population.

In. estimating supply, USDA assumed that real growth in public expenditures for agricultural research and experimentation will increase at a moderate 3 percent per year, and that technological breakthroughs will not occur. Environmental regulation now in force will continue; however, when it is profitable to do so, farmers will adopt other environmental practices, such as integrated pest management and livestock waste disposal systems for larger feed lots. Projected climatic conditions are the same as the average conditions during the 1939-1972 period-that is, a Stalling's weather index value of 110.6 (normal value is 100 ).

The USDA Economic Research Service price projections excluded sugar beets, sugarcane; cotton, cirtrus and noncitrus fruits, and corn silage. Hence, SRI estimated the prices for these commodities for 1985 and 2000. However, because of large price fluctuations, government intervention, and general uncertainty in sugar, cotton, and fruit markets, a conservative price estimate was made. Price increases for sugar, cotton, and fruit are related to the increases in production costs for these commodities and are estimated in real terms to be 0.5 percent per year. Thus, a constant differential can be maintained between production costs and prices. Net return therefore will vary in accordance with changes in yield per acre.

Corn silage prices were determined through a comparison with alfalfa hay prices. In feed rations, the ratio of corn silage to alfalfa hay is $3: 1$. This ratio was applied to the projected alfalfa hay price to obtain the estimated price for corn silage.

Table IV-5 summarizes the projected prices per unit of weight for the years 1985 and 2000 for each of the commodities included in this analysis. The prices are given in fourth-quarter 19.77 dollars on a per unlt basis.

Cost of Production. The primary data sources for the estimates of the cost of production in 1985 and 2000 for the commodities in this analysis are the Firm Enterprise Data System (FEDS) cost of production budgets. ${ }^{8}$ These FEDS budgets are crop-and location-specific and include the significant variable and fixed costs for the production of a particular 
Tab1e IV-5.

PROJECTED PRICES FOR CONVENTIONAL CROPLAND COMMODITIES

(1977 Dollars)

\begin{tabular}{|c|c|c|c|c|c|}
\hline Commodity & $\begin{array}{l}\text { Unit of } \\
\text { Weight }\end{array}$ & Estim & $\begin{array}{c}\text { ated Price } \\
1985\end{array}$ & $\begin{array}{l}\text { per Weig } \\
2000\end{array}$ & ght Unit \\
\hline Row crops & & & . & & \\
\hline Corn & Bushel & & 2.89 & 3.34 & \\
\hline Corn silage & Ton: & & 23.78 & 27.48 & \\
\hline Soybeans & Bushel & & 6.70 & 8.00 & \\
\hline Sorghum (grain) & Bushel & & 2.60 & 3.00 & \\
\hline Peanuts & Pound & . & 0.16 & 0.19 & . \\
\hline Cotton & Pound & . & 0.54 & 0.58 & · \\
\hline Sugarcane & Ton & & 19.34 & 20.88 & \\
\hline Sugar beets & Ton & & 27.58 & 31.00 & \\
\hline Potatoes & CW' & & 3.83 & 3.94 & \\
\hline Close-grown crops & & & & & \\
\hline Wheat & Bushel & & 3.80 & 4.64 & \\
\hline Oats & Bushe1 & & 1.32 & 1.53 & \\
\hline Barley & Bushel & & 2.22 & 2.58 & \\
\hline Rye & Bushel & & 2.94 & 3.40 & $\cdot$ \\
\hline Rice & $\overline{C W T}$ & & 8.11 & 10.92 & ' \\
\hline Hay & & & & & $\therefore$ \\
\hline Alfalfa & Ton & & 71.34 & 86.46 & $\because$ \\
\hline Orchards & & & & & \\
\hline Citrus fruits & Ton & & 65.00 & 70.16 & \\
\hline Noncitrus fruits & Ton & $\cdot$ & 210.00 & 235.00 & \\
\hline
\end{tabular}

Sources: Reference 7; SRI International 
commodity. Table IV-6 is an example of an FEDS production cost budget that demonstrates the scope and detail of this information.

State and county extension services were used as information sources on costs of production for several commodities not included in the FEDS budgets. However, the general format and level of detail in the extension service budgets is commensurate with that of the FEDS budgets.

Two important points with regard to both the FEDS and extension service budgets require clarification. First, these budgets represent average costs of production for a specific commodity in a particular subbasin and therefore do not reflect any differences that may occur among the land capability classes (I-IV). Discussions with USDA extension staff, agronomists, and plant physiologists suggested that price variations among the classes are insignificant. Therefore, in this analysis, costs of production were held constant for the four land capability classes, and variation in net income is attributable to changes in crop yields. Second, all the FEDS and many of the extension service budgets were prepared in 1976 dollars. These budgets were converted to 1977 dollars by applying the 6 percent increase registered for the Producer Price Index between 1976 and 1977 and then projecting these data forward to 1985 and 2000 by a factor of 0.5 percent compounded annually. (This factor is taken from USDA estimates of average increases in real production costs per acre from 1977 to $2000 .{ }^{9}$

\section{Rangeland}

The yield for rangeland and pastureland was based on the amount of animal forage produced per acre. This output was measured in animal unit months (AUM)--the amount of forage necessary to sustain one animal unit for 1 month. The analyses of the rangeland and pastureland subcategories of the rangeland land class are presented below.

Rangeland Subcategnry. II.S. Fnrest Service estimates of the number of AUMs required in 1985 and 2000 have been prepared for four regions of the United States: Western Forest (grazed), Western Range, Great Plains, and Eastern Forest (grazed). 10 Each of the 21 subbasins was included in one of these regions.

To estimate AUMs required in these regions, projections of population and of per capita consumption of beef, veal, and other meats were made. The projections for per capita consumption took into account modifications resulting from changes in income, taste preferences, and imports and exports. The estimated AUMs were then divided by the number of acres in each of the four regions to determine the number of AUMS per acre; differences in productivity among the land capability classes (I-IV) were generated from the index of productivity. ${ }^{4}$

The estimated AUM per acre were then converted to an equivalent quantity of alfalfa hay. Alfalfa io cotimatcd to be 50 percent of total 
Table IV-6

SAMPLE FEDS* PRODUCTION COST BUDGET FOR CONVENTIONAL CROPS-SOYBEANS, ILLINOIS, AREA 400

Gross recelpts from production Total receipts

Variable costs Preharvest

seed

Nitrogen

Phosphate

Pocash

Lime

Pre-merge herb

Post emerg. herb

Insect1cide

Fertilizer Appl.

Herbicide appl.

Insecticide appl.

Tractor fucl and lube

Tractor repairs

Equipment fuel and lube

Equipment repairs

Machiuery labor

Interest on op. cap.

Total preharvest

Harvese

Custom combining

Custom hauling

Tractor fuel and lube

Tractor repalrs

Equipment fuel and lube

Equipment repairs

Machinery labor

Interest on op. cap.

Total harvest

Total variable coote

Income above vartable costs

Ownership costs (depreciation, taxas, intarest, insuranre)

Tractors

Machinery and equipment

Total ownership costs

Recurn Lo land, oveiliedd, risk, and management

Land charge (share rent)

Management charge $(7.0 \%$ of gross receipts)

Total costa

Return to overhead and risk
Price or

Unit

bushel

ost/Unit

7.600

Quntity

27.100

or Cost

Per-Acre

Cost per

Unit of

Production

205.96

205.96

$\begin{array}{llr}\text { pounds } & 0.107 & 6 h .500 \\ \text { pounds } & 0.142 & 2.000 \\ \text { pounds } & 0.168 & 15.000 \\ \text { pounds } & 0.077 & 25.000 \\ \text { tons } & 6.300 & 0.210 \\ \text { acre } & 8.100 & 0.980 \\ \text { acre } & 8.100 & 0.060 \\ \text { acre } & 2.500 & 0.020 \\ \text { acre } & 2.000 & 0.141 \\ \text { acre } & 2.000 & 0.210 \\ \text { acre } & 2.000 & 0.020 \\ \text { acre } & & \end{array}$

acre

acre

acre

acre

hours

dollars

2.560

0.087

2.740

16.267

acre

bushel

12.000

0.070

$0.0 \%$

1.900

acre

acre

acre

acre

hours

dollars

2. 560

0.087

0.867

0.0
6.78

0.28

2.52

1.93

1. 'J'

7.94

0.49

0.05

0.28

0.42

0.04

3.41

1.86

0.76

2.04

7.02

1.42

$\frac{1.42}{38.55}$

0.25

0.01

0.09

0.07

U.U5

0.29

0.02

0.00

0.01

0.02

0.00

0.13

0.07

0.03

0.08

0.26

0.05

1.42

0.84

0.13

0.02

0.01

1.50

1.78

2.22

0.0

6.50

45.05

160.91

0.03

0.00

0.00

0.00

0.06

0.07

0.08

0.0

0.24

1.66

9.94

5.10

19.54

24.64

0.19

0.72

0.91

136.26

5.03

74.63

2.75

14.42

158.75

0.53 .

47.21

5.86

47.21

* Prepared by Firm Enterprise Data System, Commodity Economics Division, ESCS in cooperation with Oklahoma State University, Stillwater, Oklahoma. Feds budgets are prepared for research purposes and are not official USDA estimates of production costs. 
digestible nutrients (TDN), so 1 ton of alfalfa is equal to 1,000 pounds of TDN.11 An AUM is equivalent to 400 pounds of TDN or 800 pounds of alfalfa; thus, 1 AUM equals 0.4 ton of alfaifa hay. To determine the gross revenue per acre of rangeland, this ratio of 1:0.4 was applied to the 1985 and 2000 price estimates.

$\therefore$... Rangeland production costs cover costs of four treatment practices: fencing, water development, brush removal, and feeding. Regional differences in costs for these four practices were obtained from the Soil Conservation Service. ${ }^{12}$ The variations in production costs between the four land capability classes were not considered. Rangeland production costs, like those for agriculture, were increased at a compounded annual rate of 0.5 percent. The annual cost per acre was derived by discounting each treatment practice over its estimated life span. Subtracting the annual costs per acre from the gross revenue per acre provided the net return per acre.

Pastureland Subcategory. The methodology used to obtain estimated revenue per, acre of rangeland was used to estimate net revenue per acre of pastureland. Because pastureland differs in productivity and number of acres from rangeland, pastureland produces 4 to 16 times more AUM per acre than rangeland does.

The annual production costs were based on budgets for specific subbasins for 1,000 acres of dry land pasture production. Pastureland costs were also increased at 0.5 percent compounded annually and subtracted from gross revenue per acre to obtain the net revenue per, acre of pastureland.

\section{Forest Land}

The average net return per acre of forest 1 and is defined as the value of the standing timber (stumpage) that will be harvested per acre in the years 1985 and 2000. This definition requires a methodology that estimates the quantity and composition of harvested timber "and that projects stumpage prices. To ensure that this is an annual net return per acre, stumpage values were discounted over the life of the timber...

Two important assumptions were made in estimating the average net return per acre of forest land. First, no measure of production costs was included in the calculations for two reasons: Because of the longevity of most stocks of timber, only minimal costs are incurred to ensure mature growth, and the use of stumpage price implies the omission of harvesting and transportation costs. Second, uniform yields per acre were assumed for the four land capability classes; the high concentration of commercial forest land in land capability Classes III and IV suggests that the use of uniform yields will have no significant effect on the results of this analysis. 
Estimates of the quantity and composition of timber to be harvested per acre in the 21 selected subbasins were guided by the assumption that current output.mix (sawtimber and pulpwood) and distribution of woods (sof twood and hardwood) in each subbasin would not be significantly altered over the duration of this analysis. Each subbasin's percentage of timber harvested in a particular region (North, South, Rocky Mountains, and Pacific Coast) in $1977^{13}$ was applied to projected regional harvests for 1985 and 2000.14 In all cases, estimated harvests were disaggregated by outmit mix and wood-type distribution.

An estimate of the number of acres of commercial timberland that will be harvested in each subbasin in both time periods was prepared hy applying the rat1o of annual removal to total growing stock againet the total number of arres of commercial forcotland in each sublaslil. Projected rimber harvests were then divided by harvested acres to estimate the quantity and composition of timber to be removed per harvested acre in each subbasin.

Stumpage prices to be paid in 1985 and 2000 for hardwood and softwood sawtimber and pulpwood were estimated for each subbasin. Sawtimber prices were derived by applying 1977 prices $^{15}$ to a softwood index and a hardwood index of equilibrium stumpage prices for eight timber supply regions in the contiguous United States. 16 These prices, which are projected to 2030, are those deemed necessary to bring about an equilibrium between the U.S. Forest Service's medium level projections of timber demand and supply.

Traditionally, rates of increase of pulpwood stumpage prices have lagged behind those of sawtimber. However, recent developments in the forest products industry suggest that this trend may be altered and that rates of increase for pilpwnnd stumpage will begin to approach those of sawt 1mber. Consequently, estimates of pulpwood stumpage and sawtimber prices were derived in the same fashion. Prices paid for pulpwood stumpage in 1977 in each subbasin were projected to 1985 and 2000 at the races estimated tor sawtimber prise equilithriım.

Tables IV-7 and IV- 8 present estimates of the harvested acreage and ylelds per acre for commercial Forestland in the 21 selected subbasins for the years 1985 and 2000. Tables IV-9 through IV-12 indicate the range of sawtimber and pulpwood prices used to calculate the net returns from an acre of commercial forcatland in each of llus subbasins.

\section{Average Net Return from Two Categories of Biomass Operations}

This section presents thc analysis of the average annual nee return for two of the three primary categorles of biomass operations in the years 1985 and 2000. The three primary categories, defined in the introduction, are: food (flber)/fuel, fuel only, and cultivation of high-yield specialty crops. The first two categories are the focus of 


\section{Table IV-7}

ESTIMATED HARVESTED ACREAGE AND YIELDS

FROM COMMERCIAL FORESTLAND IN 21 SUBBASINS--1985

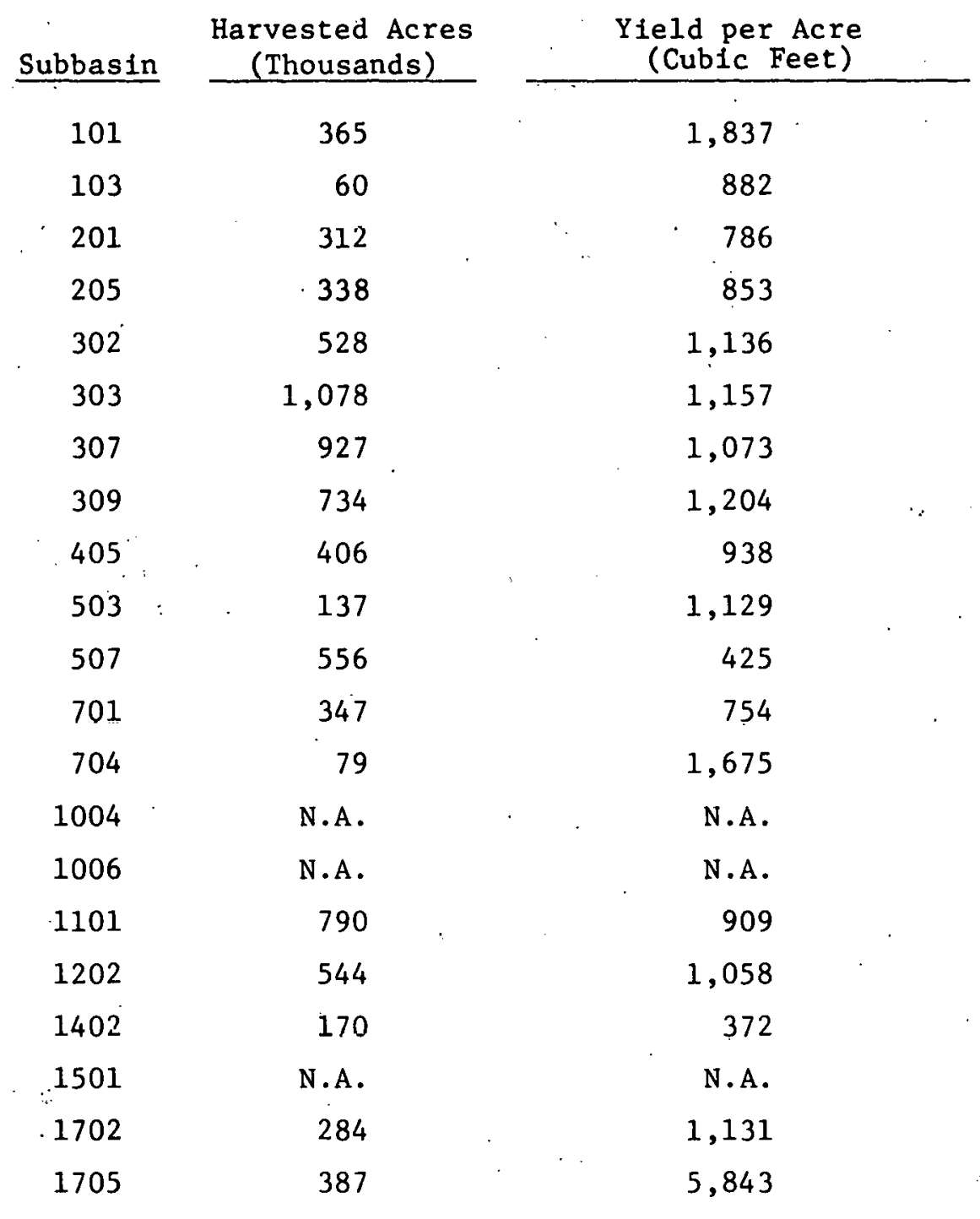

N.A. = Not Applicable 


$$
\text { Table IV-8 }
$$

ESTIMATED HARVESTED ACREAGE AND YIELDS

FROM COMMERCIAL FORESTLAND IN 21 SỤBBASINS--2000

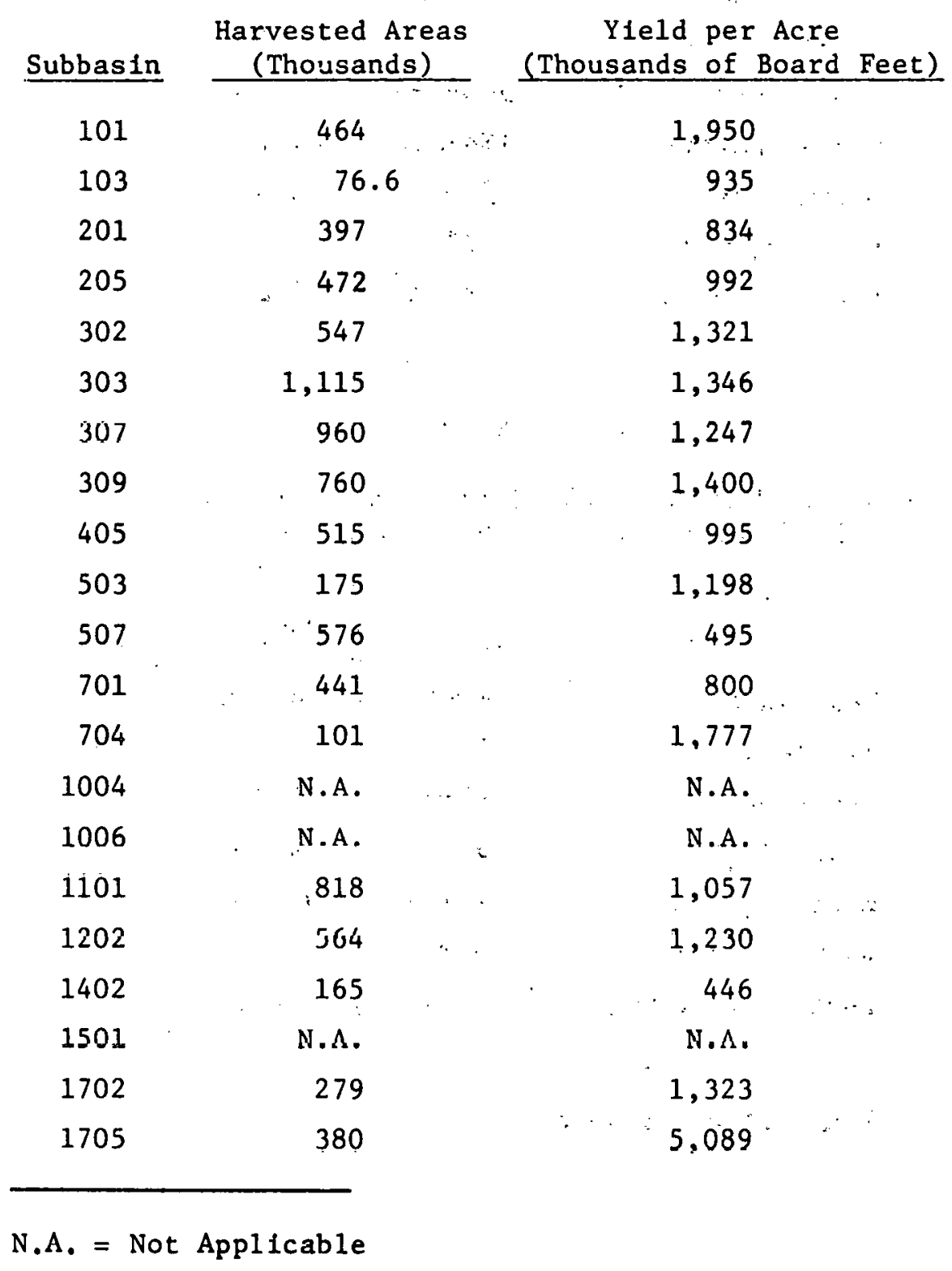


Table IV-9

RANGE OF SOFTWOOD SAWTIMBER STUMPAGE PRICES

(1977 Dollars per Thousand Board Feet)

\begin{tabular}{|c|c|c|}
\hline Region & 1985 & 2000 \\
\hline New England & $54-56$ & $78-80$ \\
\hline Mid-Atlantic & $60-125$ & $85-205$ \\
\hline South Atlantic Gulf & $140-190$. & $250-310$ \\
\hline South Central & $196-215$ & $320-350$ \\
\hline North Central & $55-65$ & $72-80$ \\
\hline Rocky Mountain & 81 & 138 \\
\hline Pacific Northwest & $128-234$ & $179-297$ \\
\hline
\end{tabular}

Table IV-10

RANGE OF HARDWOOD SAWTIMBER STUMPAGE PRICES

(1977 Dollars per Thousand Board Feet)

\begin{tabular}{|c|c|c|}
\hline Region & 1985 & 2000 \\
\hline New England & $60-65$ & $95-100$ \\
\hline Mid-Atlantic & $55-65$ & $85-95$ \\
\hline South Atlantic'Gulf & $45-75$ & $66-97$ \\
\hline South Central & $56-62$ & $66-73$ \\
\hline North Central & $63-67$ & $95-102$ \\
\hline Rucky. Múntain & N.A. & N. $\Lambda$. \\
\hline Pacific Northwest & N.A. & N.A. \\
\hline
\end{tabular}


Table IV-11

\section{RANGE OF SOFTWOOD PULPWOOD PRICES}

(1977 Dollars per Cord)

\begin{tabular}{|c|c|c|}
\hline Region & 1985 & 2000 \\
\hline New England & $8-10$ & $14-15$ \\
\hline Mid-At1antic & $9-11$ & $14-18$ \\
\hline South Atlantic Gulf & $10-26$ & $18-38$ \\
\hline South Centra1 & $10-11$ & $16-18$ \\
\hline North Central & $10-12$ & $.14-16$ \\
\hline Rocky Mountain & N.A. & N.A. \\
\hline Pacific Northwest & N.A. & N.A. \\
\hline
\end{tabular}

N.A. =Not Applicable

Table IV-12

RANGE OF HARDWOOD PULPWOOD PRICES (1977 Dollars per Cord)

\begin{tabular}{|c|c|c|}
\hline Region & 1985 & 2000 \\
\hline New England & $5-6$ & $10-11$ \\
\hline Mid-Atlantic & $2-5$ & $4-10$ \\
\hline South Atlantic Gulf & $3-4$ & $3-6$ \\
\hline South Central & $2-3$ & $3-4$ \\
\hline North Central & $6-8$ & $9-10$ \\
\hline Rocky Mounta1n & N.A. & N.A. \\
\hline Pacific Northwest & N.A. & N.A. \\
\hline
\end{tabular}

N.A. $=$ Not Applicable 
this discussion. The analysis of the cultivation of specialty crops for conversion to fuel is the subject of a separate discussion.

From these three biomass categories, 13 options were identifled for use in conjunction with certain land-use types. These options and the related land-use types are listed below.

\begin{tabular}{ll}
\multicolumn{1}{c}{ Land-Use Type } & Blomass Options \\
\cline { 1 - 2 } Row crops & $\begin{array}{l}\text { Food (fiber)/fuel } \\
\text { Fuel only }\end{array}$ \\
Close-grown crops & $\begin{array}{l}\text { Food/fuel } \\
\text { Fuel only }\end{array}$ \\
Rotation hay and pasture & Fuel only \\
Hayland & Fuel only \\
Grazed commercial forest land & $\begin{array}{l}\text { Fiber/fuel } \\
\text { Fuel only }\end{array}$ \\
Ungrazed commerclal forest land & Fiber/fuel \\
Silvicultural energy farm & Fuel only \\
Sweet Sorghum energy farm & Fuel only \\
Kenaf energy farm & Fuel unly
\end{tabular}

The net returns for these 13 options were computed and organized in accordance with the methodology, data, and land classification criteria described earlier in the section. When required, additional sources of information on biomass production were used.

A fundameillal assumption in this analysis is that individual commodity yields would remain uniform whether the output was designated for conventional or energy feedstock uses. Consideration of potential production increases that could result from advanced techniques in cultivation or plant genetlcs are beyond the purview of this stury.

The lack of potential for use as an energy feedstock eliminated several land-use types from this analysis. Because of the insignificant amount of forage produced from rangeland, pastureland, and grazed noncommercial forest land, annual net returns for biomass were not prepared. Similarly, the minimal quantity of feedstock supplied from annual tree trimmings excludes orchards as a feasible source of binmass.

'ihe following subsections prcoent the analysis of net returns for biomass from cropland and forest land for the food (fiber)/fuel and fuelonly biomass options. The detailed description of the methodology used to compute the net returns for all biomass options is presented in Appendix C.

* Discussed in the next section. 


\section{Cropland: Food (Fiber)/Fuel and Fuel-Only Options}

To estimate an annual net biomass return from cropland with the food (fiber)/fuel combination.biomass first.required the separate:calculation of the net return of residue for each commodity in each of the three landuse types. These net returns plus those generated earlier in this section for conventional crop production gave the estimated net biomass return from the food (fiber)/fuel combination option. The estimates of residue for each commodity were derived from factors that reflect the tons of residue per ton of fresh crop yield at harvest. However, because growing conditions, cultural practices, and weather variations affect the amount of residues per ton of crop yield as well as crop yield per acre, the estimates of residue generation were based on an average-specific crop yield per acre for the 3 year period 1973 to 1976. From these estimates, the quantity of flesh welght recidue and food (fther) por acrc were cunverted to dry tons per acre by applying a commodity-specific dry weight factor to each estimate.

For the fuel-only biomass option, estimates of the tons of fresh residues and food (fiber) produced for each commodity were combined with a set of dry weight factors. to obtain the total dry tons available as an energy feedstock. Table IV-13 lists the factors used for each commodity. For example, Tables IV-14 and IV-15 summarize the potential estimates of energy feedstock derived from the commodity yields presented in Tables IV -3 and IV -4 .

Feedstork Prices. A crucial palameler of this study is the estimated price that will be offered for the biomass feedstock in 1985 and 2000. These prices were computed from an SRI Internatinnal study propared fui Llie DOE. ${ }^{18}$ 'this mission analysis for the Federal Fuels from Biomass Program compared the estimated prices of biomass-derived fuels with those from conventional sources to dctermine equilibrium biomass feedstock prices. The study determined a national average price for biomass feedstocks of approximately $\$ 20.50$ per dry ton in the year 1985 and $\$ 27.50$ per dry ton in the year 2000. All prices were estimated in fourthquarter 1977 dollars and applied uniformly to all biomass feedstocks.

Cost of Production. Production costs for biomass for each commodity were formulated, in part, from ronventional agricultute production costs and modified to reflect specific conditinns associated with a luiumbet cnterprise. L1ke costs for conventional agriculture, biomass production costs were held constant across all four capability classes.

Production costs for a food (fiber)/fuel combination for each commodity include all conventional produrtion coste. Additonal production costs associated with residue utilization can be separated into three categories: 
Table IV-13

RESIDUE AND FOOD/FIBER DRY WEIGHT FACTORS FOR 1985 AND 2000

\begin{tabular}{|c|c|c|c|c|}
\hline Commodity & $\begin{array}{l}\text { Food/Fiber } \\
\text { Dry Welght } \\
\text { Factor } \\
\text { (Al1 Years) } \\
\end{array}$ & $\begin{array}{l}\text { Residue Dry } \\
\text { We1ght Factor } \\
\text { (Al1 Years) } \\
\end{array}$ & $\frac{\text { Residue }}{1985^{\circ}}$ & $\frac{\text { Factors }}{\therefore 2000}$ \\
\hline Row crops & $\therefore$ & $\because$ & & \\
\hline Corn ... & 0.85 & 0.53 & 1.10 & 1.10 \\
\hline Corn sllage & 0.28 & N.A.: & 1.00 & 1.00 \\
\hline Soybeans & 0.90 & 0.85 & 2.14 & 2.14 \\
\hline Sorghum (grain) & 0.89 & 0.40 & $1.5 \cdot 2$ & 1.57 \\
\hline Peanuts & 0.94 & 0.80 & 1.42 & 1.35 \\
\hline Cotton & 0.93 & 0.50 & 2.30 & 2.20 \\
\hline Sugarcane & 0.23 & 0.30 & 0.42 & 0.39 \\
\hline Sugar beets & 0.17 & 0.20 & 0.52 & 0.52 \\
\hline Potatoes & 0.21 & 0.11 & 1.00 & 1.00 \\
\hline \multicolumn{5}{|l|}{ Close-grown crops } \\
\hline Wheat & 0.89 & 0.90 & 2.25 & 2.00 \\
\hline Oats & 0.90 & 0.90 & 1.30 & 1.20 \\
\hline Barley, & 0.89 & 0.91 & 1.30 & 1.10 \\
\hline Rye & 0.89 & 0.85 & 2.50 & 2.50 \\
\hline Rice & 0.93 & 0.50 & 2.30 & 2.20 \\
\hline \multicolumn{5}{|l|}{ Hay . } \\
\hline Alfalfa & 0.90 & N.A. & 1.00 & 1.00 \\
\hline $\begin{array}{l}\text { * For crops, tons } \\
\text { welght at harvest }\end{array}$ & per & n of crop yle & both at & fresh \\
\hline
\end{tabular}


Table IV-14

ESTIMATED ENERGY FEEDSTOCK IN SUBBASIN 206--1985

(Dry Tons)

Yield

\begin{tabular}{|c|c|c|c|c|}
\hline Commodity & Fresh Tons & Food/Fiber & Residue & Total. \\
\hline \multicolumn{5}{|l|}{ Row crops } \\
\hline Corn & 390,890 & 332,256 & 227,888 & 560,144 \\
\hline Corn silage & 756,368 & 211,780 & N.A. & N.A. \\
\hline Soy beans & 35,590 & 32,031 & 64,738 & $96 ; 769$ \\
\hline Sorghum (grain) & 7,016 & 6,244 & 4,265 & 10,509 \\
\hline Peanuts & 14,189 & 13,337 & 16,118 & 29,455 \\
\hline Cotton & 506 & 470 & 582 & 1,052 \\
\hline - Sugar cane & -- & -- & -- & -- \\
\hline Sugar beets & -- & -- & -- & -- \\
\hline Potatoes & 48,680 & 10,223 & 5,355 & 15,578 \\
\hline Total & $1,253,239$ & 606,341 & 318,946 & $713 ; 507$ \\
\hline Close-grown crops & & & & $\cdot$ \\
\hline Wheat & 195,149 & 173,682 & 395,176 & 568,858 \\
\hline Oats & $1.9,673$ & 17,705 & 23,017 & 40,722 \\
\hline Barley & 109,817 & 97,737 & 129,913 & 227,650 \\
\hline Rye & 101,626 & 90,447 & 215,955 & 306,402 \\
\hline Rice & -- & -- & -- & - - \\
\hline Total & 426,265 & 379,571 & 764,061 & $1,143,632$ \\
\hline Grand Total & $1,679,504$ & 985,912 & $1,083,007$ & $1,857,139$ \\
\hline
\end{tabular}


Table IV-15

ESTIMATED ENERGY. FEEDSTOCK IN SUBBASIN 206--2000

(Dry Tons)

Yleld

\begin{tabular}{|c|c|c|c|c|}
\hline \multirow[b]{2}{*}{ Commodity } & \multirow{2}{*}{\multicolumn{2}{|c|}{ Fresh Tons Food/Fiber }} & \multirow{3}{*}{ Residue } & \multirow{3}{*}{ Total. } \\
\hline & & & & \\
\hline Row crops & 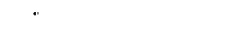 & & & \\
\hline Corn & 439,474 & 373,552 & 256,213 & 629,765 \\
\hline Corn silage & 739,729 & 207,124 & -- & 207,124 \\
\hline Soybeans & 126,091 & 113,481 & 229,359 & 342,840 \\
\hline Sorghum (grain) & 9,542 & 8,492 & 5,992 & $14,48.4$ \\
\hline Peanuts & 43,982 & 41,343 & 47,500 & 88,843 \\
\hline Cotton & 300 & 279 & 330 & 609 \\
\hline Sugar cane & -- & -- & -- & -- \\
\hline Sugar beets & -- & -- & -- & -- \\
\hline Potatoes & 38,298 & 8,042 & 4,212 & $12,254$. \\
\hline Total & $1,397,416$ & 752,313 & 543,606 & $1,295,919$ \\
\hline Close-grown crops & & & & $\therefore$ \\
\hline Wheat & 222,706 & 198,208 & 400,870 & 599,078 \\
\hline Oats & 18,720 & 16,848 & 20,217 & 37,065 \\
\hline Barley & 76,933 & 68,470 & 77,009 & 145,479 \\
\hline Rye & 10,262 & 9,133 & 21,806 & 30,939 \\
\hline Rice & -- & -- & $=$ & - \\
\hline Toṭal & 328,621 & 292,659 & 519,902 & 812,561 \\
\hline Grand Total. & $1,726,837$ & $1,044,972$ & $1,063,508$ & $2,108,480$ \\
\hline
\end{tabular}


- Opportunity cost

- Collection cost

- Transportation cost.

The opportunity cost of each commodity's residue is the value attached to that residue in its next best use. Currently, residues are returned to the soll for structural and fertility purposes. For example, corn residue in the Midwest is used for erosion abatement, whereas smal1grain residue in the High Plains improves moisture retention and acts as a preplant fertilizer. When residues are used as an energy feedstock, the owner of the residue incura a cost fur replacing the residue.

Residue collection costs are assessid according to the method user in propare the feedstuck. The two most common forms are chopping and bailing. For this analysis, all collection cost estimates are based on the assumption that the feedstock would be chopped.

Transportation costs were estimated at $\$ 0.15$ per ton-mile, with an additional charge of $\$ 0.50$ per dry ton for handling and storage. Previous SRI studles have assumed an average blomass travel distance to a conversion plant of 15 miles. On this basis, transportation costs are estimated at $\$ 2.75$ per ton of transported plant material in 1985 and $\$ 2.95$ per ton in the year 2000. Transportation costs are 1ncurred by the farmer--the price per dry ton offered by the conversion facility is assumed to include delivery charges.

Production costs for the use of the entire crop as an energy feedstock include most of the conventional production costs. The major change is an alteration in the harvest costo for many of the comminities considered. Furthermore, some of the additional costs incurred for residue utilization are also applicable to a fuel-only biomass operation.

This analysis assumes that harvesting operations and costs for whole plant utilization would be closely aligned to those for corn silage in each of the 21 subbasins. Two scenarios are envisioned for silage harvesting. The firot scenario is a green-crop harvest, in which the plants are cut, chopped, and loaded in, one serial process. The plant materlal is then transported to a conversion facility. The second scenario is a dry-chop operation in which the plant material is mowcd and wlindrowed to tield dry, then chopped, loaded, and transported.tn the conversion fallity. The conveulional harvest costs for several of the commodities included in this study are less than that for silage because the conventional harvest removes only the food (fiber) component rather than the entire plant. Consequently, changes were made in harvest costs as required only for the following commodities:

- Row crops

- Corn

- Soybeans 
- Cotton

- Sorghum (grain)

- Close-grown crops

- Wheat

- Oats

- Barley

- Rye

- Rice.

The opportunity and collection costs stemming from residue utilization are also applicable to the fuel-only configuration. The removal of the whole plant in one operation implies that residues will be removed at the same time. Transportation costs are those assumed for residues. Collection costs were omitted because all plant material is removed in the harvest operation.

Tables IV-16 and IV-17 summarize the additional estimated costs incurred for both food ( $f$ iber)/fuel and fuel-only biomass operations for the years 1985 and 2000. The costs for the operations in the year 2000 were calculated by increasing the 1985 estimate at a rate of 0.5 percent compounded annually.

\section{Fiber Fuel Combination}

Forest residues are defined as those sections of the tree that are not removed during harvest. The calculation of a net return from forest residues requires estimates of the average amount of residue that would be available in 1985 and 2000 from an acre of harvested commercial forestland. The net return developed for conventional silviculture output was combined with a separate net return developed for the use of forest residues as an energy feedstock.

The few available estimates of the quantities of forest residues are incomplete. The only consistent and complete estimates of logging residues on a nationwide basis are those from the U.S. Forest Service.13 These estimates, however, include only residues from so-called growing stock volumes, defined by the Forest Service as wood in the stems of growing stock trees that are 5 inches or more in diameter at breast height ( 4.5 feet above ground level). Volume is calculated from a 12-inch stump height to a minimum 4-inch top diameter.

Clearly, Forest Service data cover only a portion of toral logging residues. Therefore, additional estimates were prepared for the residues of "rough, rotten, and dead" commercial species that are 5 inches or more in diameter, to a minimum 4-inch diameter; portions of stems less than 4 inches in diameter; and branches and foliage for all trees in harvest areas which were of commercial species and at least 5 inches in diameter at breast height. Not Included in these figures are residues from any 
Table IV-16

ADDITIONAL PRODUCTION COSTS ASSOCIATED WITH FOOD (FIBER)/FUEL AND FUEL-ONLY BIOMASS OPERATIONS IN 1985

(1977 Dollars per Dry Ton)

\begin{tabular}{|c|c|c|c|c|}
\hline Feedstock & $\begin{array}{l}\text { Opportunity } \\
\text { Cost }\end{array}$ & $\begin{array}{c}\text { Collection } \\
\text { Cost } \\
\end{array}$ & $\begin{array}{c}\text { Transportation } \\
\text { Cost } \\
\end{array}$ & $\begin{array}{l}\text { Total } \\
\text { Cost }\end{array}$ \\
\hline \multicolumn{5}{|l|}{ Row crops } \\
\hline Corn & 19.00 & 15.00 & 2.75 & 36.75 \\
\hline Soybeans & 28.50 & 23.00 & 2.75 & 54.25 \\
\hline Sorghum (grain) & 35.00 & 15.00 & 2.75 & 52.75 \\
\hline Peanuts & 6.25 & 15.00 & 2.75 & 24.00 \\
\hline Cotton & 10.00 & 16.00 & 2.75 & 28.75 \\
\hline $\begin{array}{l}\text { Sugarcane } \\
\text { (bagasse) }\end{array}$ & 20.00 & N.A. & 2.75 & 22.75 \\
\hline Sügar beets & 25.00 & 40.00 & 2.75 & 67.75 \\
\hline Potatoes & 45.50 & 73.00 & 2.75 & 121.25 \\
\hline Close-grown crops & . & & . & \\
\hline Wheat & 11.00 & 9.00 & 2.75 & 22.75 \\
\hline Oats & 5.50 & 9.00 & 2.75 & 17.25 \\
\hline Barley & 9.00 & 9.00 & 2.75 & 20.75 \\
\hline Rye & 11.00 & 11.00 & 2.75 & 24.75 \\
\hline Rice & N.A. & 17.50 & 2.75 & 20.25 \\
\hline
\end{tabular}

N.A. =Not applicabie.

Snurre: Reference 19 
Table IV-17

ADDITIONAL PRODUCTION COSTS ASSOCIATED WITH FOOD (FIBER)/FUEL AND FUEL-ONLY BIOMASS OPERATIONS IN 2000

(1977 Dollars per Dry Ton)

Feedstock

Row crops

Corn

Soybeans

Sorghum (grain)

Peanuts

Cotton

Sugarcane

(bagasse)

Sugar beets

Potatoes

Close-grown crops

Wheat

Oats

Barley

Rye

RIce

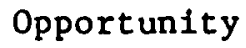

Cost

20.50

30.50

37.50

6.75

10.75

21.50

27.00

49.00

11.90

6.00

9.70

11.85

N.A.
Collection

Cost
Total Cost

Cost

39.45

57.95

56.45

25.70

$2.95 \quad 30.95$

$2.95 \quad 24.45$

$2.95 \quad 72.95$

2.95 .130 .45

78.50

9.70

2.95

24.55

9.70

2.95

18.65

9.70

2.95

22.35

11.85

2.95

26.65

18.85

2.95

21.80

N.A.=Not applicable.

Source: Reference 19 
trees of non-commercial species on harvested areas; residues from any trees less than 5 inches in diameter at breast height; all rough, rotten, and dead trees that are not harvested; and all stumps and root systems.

Table IV-18 lists the residue coefficients used to convert estimated timber harvest per acre to dry residue tons per acre. These coefficients, prepared for hardwoods and softwoods in four major geographical sectors of the United States, were applied in a weighted formulation to reflect the distribution of wood types in each subbasin. The coefficients are based on 1970 timber utilization standards, and therefore they probably will change in the future. To the extent that primary forest products manufacturers continue to accept smaller and lower-grade timber, the quantity of available forest residues can be expected to be reduced. In addition, whole-tree harvesting and chipping are likely to become more prevalent, leaving many sites virtually devoid of above grcund residues.

Table IV-18

LOGGING RESIDUE COEFFICIENTS

BY WOOD TYPE, RESIDUE TYPE, .

AND GEOGRAPHICAL SECTOR

(Dry Tons per Thousand Cubic Feet)

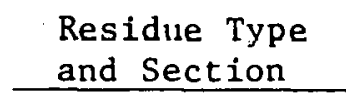

Aboveground

North

South

Rocky Mountain

Pacilic Cuast
Coefficients

Softwood Hardwood

Reference 20

\section{Average Net Return From Fuel-Only Operation}

The estimated amount of timber that will be harvested from an acre of commercial forestland in the years 1985 and 2000 in the 21 selected subbasins was converted to an equivalent number of dry tons per acre. This total, combined with the previously derived estimates of dry tons of residue per acre, yielded an estimate of the total amount of dry tons available from an acre of harvested commercial forestland in 1985 and 2000 . 
Several U.S. Forest Service publications were reviewed to obtain an approprtate conversion factor for harvested timber.21 These publications stated that, on average, 1 ton of air-dry chips may be recovered from 0.83 standard cords of wood. Conversion from cords to cubic feet was done by a factor of 85 cubic feet per cord.13 on this basis, 0.83 cords equals: 70.55 cubic feet of wood. Although this factor is a national average and thereby eliminates regionally specific differences, it has been used as a general indicator. Table IV-19 gives the estimated blomass potentially avallable from each of the 21 subbasins in the year 1985, and Table IV-20 gives the potential available in 2000 .

Cost of Production. Net returns from conventional silviculture were computed in terms of stumpage value. Therefore, no production costs were Included. Production costs for a fiber/fuel enterprise encompass costs assoclated with residue collection, chipping, and transportation. Costs of production for a fuel-only operation include all costs from harvest to transportation to a conversion facility. Production costs related to either a food/fuel or a fuel-only operation were held constant across all four land capability classes.

Forest residues are generally scattered over a wide area. Therefore, residues have to be gathered, reduced by processing through a chipper, and transported to a conversion facility. Reduction would probably occur in the woods.

As distinct from agriculture residue, forest residues generally have no positive value to forest owners. The existence of logging residues is often an impediment to regeneration of the forest after harvest. Thus; it is conceivable that some forest landowners would pay for the removal or at least transportation of forest residues.

Conversely, in some situations, a moderate amount of forest residues may be desirable because they offer some protection to very young trees. It has also been argued that some minimum amount of residue, particularly foliage, should remain in harvest forestland to retard erosion and ensure a certain level of nutrient matter for the soil. However, this analysis has not attached a positive value to forest residues.

Costs of collecting, reducing, and transporting logging residues are currently estimated at approximately $\$ 23$ per dry ton in the South to between $\$ 44$ and $\$ 61$ per dry ton in the Pacific Northwest. A more specific breakdown of these costs is preocnted in Table IV-21. Note that costs were increased 6 percent from 1976 to 1977 and were projected to 1985 and 2000 at 1 percent, compounded annually. 


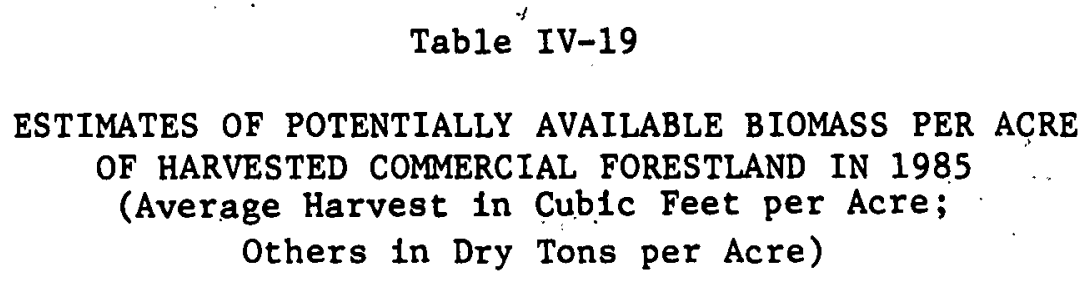

1501

1702

1705

1,837

26

12.5

13.1

39.1

882

786

11.1

6.8

19.3

853

12.1

9. 1

20.2

9.9

22.0

1,136

16.1

12.7

28.8

1,157

16.4

9.1

25.5

15.2

8.8

24.0

17.0

9.9

26.9

13.3

6.5

19.8

16.0

11.5

27.5

425

6.0

4.3

10.3

754

10.7

5.2

15.9

1,675

23.7

17.0

40.7

N. A.

N. A .

N.A.

N.A.

N.A.

N.A .

N.A.

N.A.

12.9

7.4

20.3

8.7

23.7

2.1

7.4

372

5.3

N.A.

N.A.

N.A.

N.A.

16.0

7.9

23.9

1,131

83.0

41.0

124

N.A. =Not applicable.

Source: SRI International 
Table IV-20.

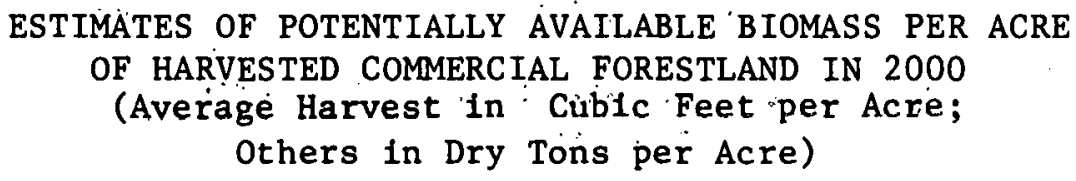

13.3

7.2

20.5

201

834

11.8

9.7

21.5

205

992

14.0

11.5

25.5

302

1,321

18.7

14.8

33.5

303

1,346

19.0

10.6

29.6

307

1,247

17.7

10.2

27.9

309

1,400

19.8

11.5

31.3

405

995

14.1

6.9

21.0

503

1,198

17.0

12.2

29.2

507

495

7.0

5.0

12.0

701

800

11.3

5.5

16.8

704

1,777

25.2

18.1

43.3

$10 \cap 4$

N.A.

N. $\Lambda$.

N. A .

N.A.

1006

1,057

15.0

8.6

23.6

1202

1,230

17.4

10.0

27.4

1402

446

6.3

2.5

8.8

1501

N.A.

N.A.

N.A.

N.A.

1702

1,323

18.7

9.3

28.0

1705

5,689

80.6

40.0

120.6

N.A.=Not applicable.

Source: SRI International 
Table IV-21

ESTIMATES OF COLLECTION, REDUCTION, AND TRANSPORTATION COSTS

FOR LOGGING RESIDUES IN TWO REGIONS.

(1976 Dollars per Dry Ton)

\begin{tabular}{lrr} 
& & \multicolumn{1}{c}{ Cost } \\
\cline { 3 - 3 } Pacific Northwest & & \\
Collection &. & $27.70-45.50$ \\
Chippiug & $5.90-15.00$ \\
Transportation (50 mi.) & $8.50-10.00$ \\
Total delivered cost & $43.60-61.00$
\end{tabular}

South

Collection $\quad 9.30$

Chipping 5.60

Transportation (20 mi.) $\quad 5.60$

Labor

2.50

Total delivered cost $\quad 23.00$

Sotirce: Reference 20

Collection costs in the Pacific Northwest are based on a high-lead logging systèm beccause of rough cerra1n. Collectiun cusls, Lherefure, are three times those incurred in the. South, where skidders can be used. The distance forest residues would have to be transported tends to be longer in the Pacific Northwest than those envisioned in this analysis; again, this is attributable to steep terrain.

Est imated costs for residue utilization are not available for all 21 selected subbasins. Therefore, residue utilization costs for the South were applied to the Northern region, and the Pacific. Northwest costs were applied to the Rocky Mountain region.

Production costs for converting standing biomass to chips through the use of existing mechanized systems encompass harvesting; chipping, and transportation costs. Interestingly, the costs estimated for using standing biomass are less than those for collecting "free" logging residues. This results primarily from the localization of the feedstock. 
An evaluation of the costs of a whole-tree harvesting/chipping operation was conducted by JPR Associates. ${ }^{22}$. The results of their work are presented in Table IV-22. The 1976 costs were escalated at 6 percent to 1977 and the 1977 costs were projected to 1985 and 2000 at 1 percent, compounded annually.

Table IV-22

COST OF HARVESTING, REDUCING, AND TRANSPORTING

STANDING BIOMASS USING THE WHOLE-TREE METHOD IN VERMONT

(1976 Dollars per Dry Ton)

\begin{tabular}{lr}
\multicolumn{1}{c}{ Item } & \multicolumn{1}{c}{ Cost } \\
\cline { 2 - 2 } Felling & 1.20 \\
Skidding & 3.70 \\
Chipping & 2.80 \\
Transport & 3.20 \\
Delivered cost & 10.90 \\
Bark and wood loss & 2.40 \\
\hline \multicolumn{1}{c}{ Total cost } & 13.30
\end{tabular}

Sunlie: Reference 22

Battelle reported costs of $\$ 22.00$ per dry ton (1976 dollars). ${ }^{23}$ Battelle, however, assuined harvesting trees cunventionally with chain saws, rather than mechanically. Felling and skidding costs were approximately 2.7 times greater than those estimated by JPR. Both studies reported similar chipping and transportation costs.

This analysis used the JPR cost estimate. The JPR estimate, however, is restricted to land that is flat or gently rolling. Therefore, this estimate most likely is inapplicable to much of the commercial forestland in the Pacific Northwest or the Rocky Mountains. Hence, to estimate the cost of whole-tree chipping in these two regions, the ratio of residue utilization costs for the Pacific Northwest to the Northeast was applied to the JPR estimates. This methodology is intended to give order-ofmagnitude estimates.

Average Annual Net Return: Energy Farms

The previous discussions have focused on the net returns available to elther a food(flber)/fuel or a fuel-only biomass enterprise. These 
scenarios were developed for the utilization of conventional crops with existing technologies and farm management practices.

An alternative to this framework is an energy farm. This concept envisions the application of innovative cultivation and management techniques to one or several biomass species to achieve the greatest yield possible and to ensure a continuous supply of harvested biomass. Although the concept has received considerable attention, 20,24 and numerous experimental and research projects have been initiated, as yet no energy farm exists.

This study incorporates information from several sources to present an economic evaluation of three energy farm candidates: sweet sorghum, kenaf, and silviculture (short-rotation hardwoods). Each is discussed below.

Sweet Sorghum Cultivation. Sweet sorghum will grow in a variety of soils, but best growth is achieved in loams and sandy loams. Adequate soil moisture and good drainage are important to good yields. Optimum planting time for satisfactory germination occurs when the soil reaches $21^{\circ} \mathrm{C}(70 \circ \mathrm{F})$ and sufficient moisture is available for germination. Germination occurs in 3 to 5 days. Most sweet sorghum has been planted in rows 1.1 meters ( 42 inches) apart. Cultivation is necessary to minimize weed growth until canopy closure. Maturity at harvest varies with varieties and regions.

In the southern areas of sorghum cultivation, the planting period is usually from the middle of April to the middle of May. In the northern part of the sweet surghum belt, the best planting season may be ilmlled to 10 to 15 days during mid-May to achieve maturity before the first killing frost. Specific planting times depend on local climatic features and on the variety of sweet sorghum planted. For example, Rio sweet sorghum may be planted from March until August in southern Texas. This variety also matures in 100 to 120 days, making harvesting possible from July until December. Consequently, two sorghum crops per year may be possible in areas having a long growing season.

Sweet sorghum is subject to insect and disease problems. A few of the major diseases are: red rot, one of the most destructive in the southeast; downiy m1ldew; musait; grey 1eaf spot; bacterial stripe; leaf blight; smut; and seedling blight. Disease control measures include the planting of resistant varieties, crop rotation, and chemical treatments. Insect damage to sweet sorghum generally is slight but occasionally is severe.

Althuugh sweet sorghum is a promising energy feedstock, development of the appropriate agricultural techologies needed to realize its potential are in the initial phase. Specifically, sweet sorghum varieties that are particularly suited to the various agricultural regions and cultivation practices that will enable sweet sorghum to attain high yields at low cost over a maximum harvest season need to be developed. 
Initial research efforts, to advance alternative agricultural technologies have been conducted by Battelle at four sites in the United. States (Texas, Louisiana, Mississippi," and Ohio). ${ }^{25}$ This research suggests that the application of narrow-row spacing significantly increases sweet sorghum yields per. acre: For example, at the Weslaco, Texas site, yields of the commercial varlety, Rio, rose from 6 dry tons per acre at 1 meter (39.37 inches) row spacing to 9.5 dry tons at 0.7 meters $(27.55$ inches) row spacing. Similarly, experiments conducted in Meridian, Mississippi, showed that yields per acre increased from 9 dry tons to 11.2 dry tons as row spacing decreased from 1.1 meters ( 43.3 inches) to 0.6 meters (23.6 inches). Comparable findings from Louisiana and Ohio confirmed these results.

On the basis of these experimental results, estimates of commercial yields per acre of sweet sorghum for biomass production have been prepared. Table IV-23 presents the estimated yields of sweet sorghum for 5-year periods between 1980 and 2000 .

Table IV-23

GOALS FOR COMMERCIAL YIELDS OF SWEET SORGHUM FOR BIOMASS PRODUCTION

(Tons per Acre)

$\begin{array}{lll}\frac{\text { Fresh Weight }}{\text { Total }} & \frac{\text { Dry Weight }}{\text { lotal }} \\ \text { Stalks } & \text { Plant } & \text { Stalks Biomass }\end{array}$

U.G. Gouth 1980

1985

1990

1995

2000

$23 \quad \cdots 31$

$25 \quad 35$

39

28

43

31

47

$\begin{array}{rr}8 & 11 \\ 9 & 12 \\ 10 & 13 \\ 11 & 15 \\ 12 & 16\end{array}$

U.S. Midwest 1980

1985

1990

1995

2000

$\begin{array}{ll}18 & 26 \\ 19 & 29 \\ 22 & 32 \\ 24 & 35 \\ 26 & 39\end{array}$

$\begin{array}{rr}6 & 9 \\ 7 & 10 \\ 8 & 11 \\ 9 & 12 \\ 10 & 14\end{array}$

Note: Assumes that 1980 commercial yields equal two-thirds 1977 experimental yields obtained in Louisiana, Texas, and Ohio. Projections beyond 1980 assume a 2 percent average annual growth rate.

Source: Reference 25 
To generate a net return for each land capability class, estimated sweet sorghum production was tied to the productivity index developed for corn in each of the 21 selected subbasins.

Production Costs. As with all other commodities considered in this analysis, it is necessary to estimate the production costs of sweet sorghum to calculate a net return per acre. For scveral reasons, however, sweet sorghum production costs cannot be well defined at this time.

First, only small acreage of sweet sorghum is grown commercially in the United Statee. No owcet sorghum is grown for crystalliiie sugdi, alld relatively small entrepreneurs grow only a few thousand arres for syrup production. The single major U.S. producer of sweet surglum, Whoonla Sorghum Company in Cedar Rapids, Iowa, grew on1y 450 hectares in 1977. Other producers of comparable size are located in Arkansas, Alabama, Indiana, Florida, and other southeastern states. Therefore, unlike other commodities, no statistical base of production cost information has yet been developed for sweet sorghum.

Another factor limiting the usefulness of current cost estimates for sweet sorghum is that technology used to grow sweet sorghum for energy purposes will undoubtedly differ from current practices. Currently, most commercial operations are extremely labor-intensive, but this would be infeasible in large-scale operations. Moreover, equipment now available is unsuitable for harvesting sweet sorghum. Where hand labor is not employed, growers have modified ensilage harvesters to harvest their crops. This equipment must necessarily operate at relatively slow speeds to produce stalks for syrup production. Therefore, the development of heavy-ducy equipment capable ot operating at produrtinn rates rnmparable to existing harvesters is required.

Input requirements and their costs also will be altered as growers gradually move up the learning curve in the development of this new crop. As new varieties are developed for biomass production, modifications in present cultural requirements may be necessary.

Given the above reservations, estimates of 1.977 sweet sorghum.production costs were prepared for three regions of the United States. These estimates, given in Table IV-24, are based on information developed by Battelle, ${ }^{25}$ USDA, and individual state experiment stations for analogous crops such as grain suighum, curn, and sugarcane. In the calculation of the net return per acre, cost of production estimates were held constant over all four land capability classes. Hauling was assessed at $\$ 2.75$ per dry ton in 1985 and $\$ 2.95$ per dry ton in 2000 . The 1977 costs were increased at 0.5 percent, compounded annually to the year 1985 and 2000 .

Research on ratooning crops is currently being conducted. Trial findings suggest that some varieties ratoon better than others, and that ratoon yields are greatly affected by cutting height, herbicides, and fertilizer applications. Until further information is developed, a single crop per year assumption will be retained. 
Table IV-24

ESTIMATED SWEET SORGHUM PRODUCTION COSTS

(1977 Dollars per Acre)

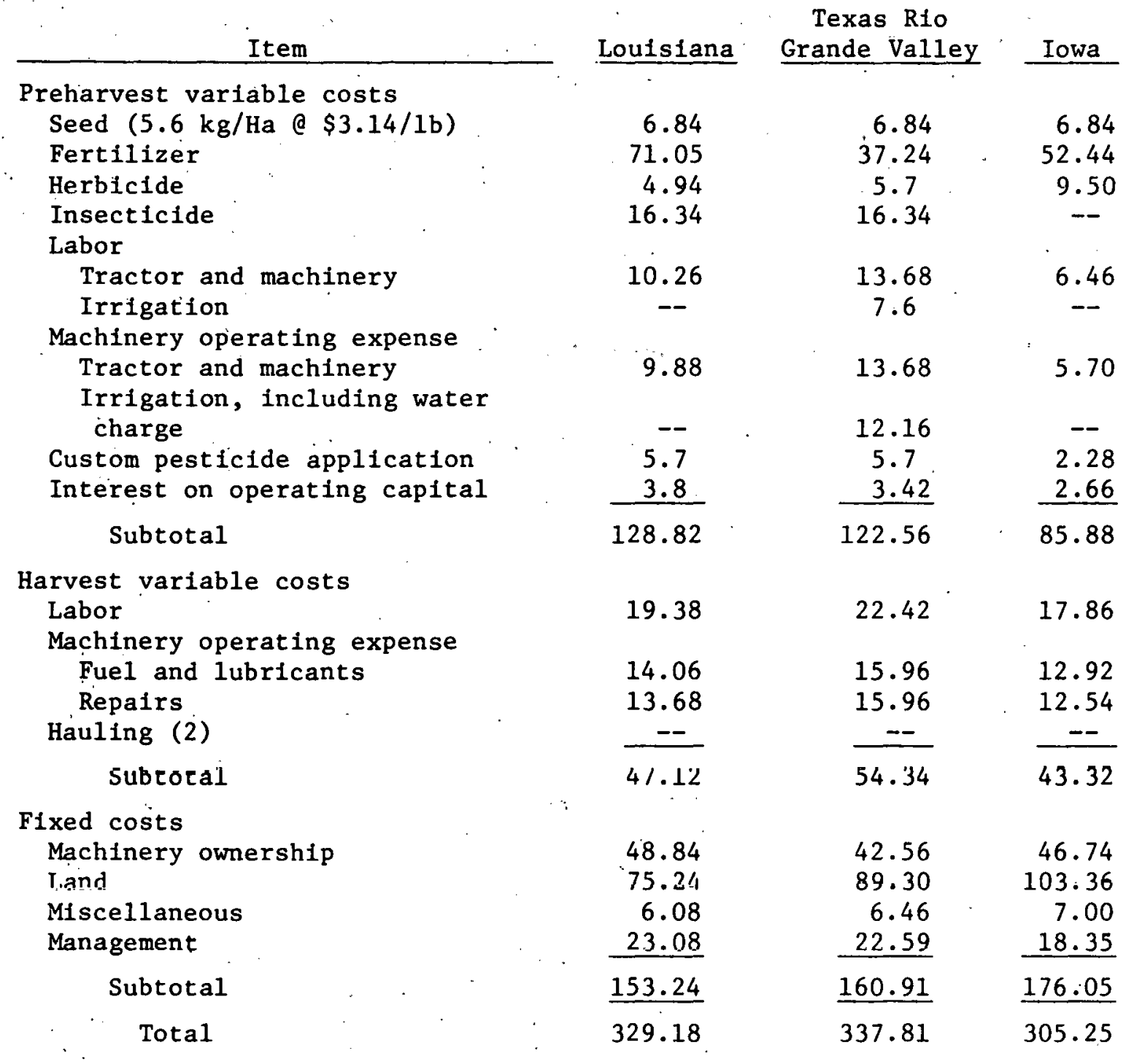

Source: Reference 25 
Kenaf Cultivation. Kenaf (Hibiscus cannabinus), an annual plant that reproduces by seed only, is a member of the family Malvaceae (which includes cotton, hollyhock, and okra). Growth may range from 8 to 20 feet in embranched thick stands. The stems contain an outer layer of long bast or bark, fibers, and a thick inner core of shorter woody fibers surrounding a central pith: Large, showy, cream-colored flowers are borne in the axils of the leaves. The plant is wind-firm but frost-sensitive.

Kenaf stalks consist of more than 50 percent cellulose. Foliage may constitute as much as 60 percent of the aboveground plant weight, depending on plant spacing. In closely spaced plantings, the lower leaves shade out and fall to the ground. Generally, the dry weight of the total aboveground plant is 1.2 times that of the stalk itself. Dry-to-fresh weight ratius range fruili 0.20 to 0.38 .26

In the southern areas of kenaf cultivation, the planting period ranges from late April to mid May. In the northern regions, planting dates are coordinated with other row crops (e.g., corn and soybeans). The plant generally reaches maximum economic growth in less than 6 months. Kenaf thrives under conditions of high temperatures and abundant soil moistures, but will not tolerate standing water or water-logged soils. Because minimal growth occurs when day temperatures fall below $500 \mathrm{~F}$ $\left(10^{\circ} \mathrm{C}\right)$, only one crop per year probably would be possible in most areas.

Kenaf is subject to insect problems. The most serious pests are root-knot nematodes, Efforts to develop nematode-resistant varieties are being conducted by crossing cultivated types with wild accessions that are found to be resistant by screening and by hybridizing kenaf with roselle. 27 Roselle, a slower growing plane similar to kenaf, has a high level of nematode resistance.

A pivotal component of this study regards kenaf production per acre. Currently, commercial yields average 5-8 dry tons per acre. $2 y$ Stem ylelds from irrigated experimental plots in Georgia averaged 13.2 tons per acre (199 days), whereas experimental yields of replicated test plots in Florida have acrained 20 dry cons per acre. ${ }^{29}$ Major difficulties occur, however, in translating experimental results to large-scale commercial conditions.

This analysis assumed that commercial production of kenaf would attain levelo of approximately 8 dry tons per acre in 1985 and 12 dry tons per acre by the year 2000. A 12-dry-ton figure has also been suggested by USDA. To permit the calculation of a yield for each land capabillty in tons, kenaf production has been tied to the productivity index developed for corn in each of the 21 selected subbasins.

Production Costs. Estimated costs of producing kenaf were developed by USDA for six sites. 28 Total estimated costs of growing and harvesting kenaf ranged from a low of $\$ 166$ per acre in eastern Texas to a high of $\$ 227$ per acre in northern Florida. (See Table IV-25) These estimates 
Table IV-25

KENAF: PRODUCTION COST ESTIMATES PFR ACRE IN SELECTED AREAS

\begin{tabular}{|c|c|c|c|c|c|c|c|c|}
\hline Cost Item & & $\begin{array}{c}\text { North } \\
\text { Flor1da } \\
\end{array}$ & $\begin{array}{l}\text { S.E. } \\
\text { Georg1a }\end{array}$ & $\begin{array}{l}\text { W. Central } \\
\text { Alabama } \\
\end{array}$ & $\begin{array}{c}\text { Central } \\
\text { M1881881pp1 }\end{array}$ & $\begin{array}{l}\text { N. Central } \\
\text { E. Central } \\
\text { Loule1sne } \\
\end{array}$ & 8 & $\begin{array}{r}\text { East } \\
\text { Texas } \\
\end{array}$ \\
\hline Preharvest operat & Lon cost & & & & & & & \\
\hline Seed & & 8.00 & 8.00 & 8.00 & 8.00 & 8.00 & & 8.00 \\
\hline Fertilizer & $\therefore$ & & . & & & & & \\
\hline N1trogen $N$ & & 29.90 & 28.60 & 24.40 & 25.74 & 22.88 & & 18.90 \\
\hline Phosphorus P & & 16.80 & 16.80 & 19.76 & 34.30 & 13.00 & & 18.88 \\
\hline Potash K & & 8.00 & 8.80 & 8.25 & 6.60 & 2.40 & & 1.00 \\
\hline Lime & & 2.31 & 2.40 & 2.40 & $\cdots$ & -- & & -- \\
\hline Subtotal & & 57.01 & 56.60 & 54.81 & 66.64 & 38.28 & & 38.78 \\
\hline Nemat 1c1de ${ }^{\star}$ & & 32.00 & 32.00 & 32.00 & 32.00 & 32.00 & & 32.00 \\
\hline Herbicide & & 8.00 & 8.00 & 8.00 & 8.00 & 8.00 & & 8.00 \\
\hline Labor & & 7.71 & 5.59 & 6.03 & 5.38 & 6.07 & & 5.87 \\
\hline Power ${ }^{\dagger}$ & . & 8.02 & 7.92 & 7.92 & 8.10 & 7.92 & & 7.61 \\
\hline Equipment $\neq$ & & 2.72 & 2.71 & 2.71 & 2.71 & 2.71 & & 2.70 \\
\hline $\begin{array}{l}\text { Interest ( } 9 \% \text { on } \\
\text { half preharvest }\end{array}$ & $\begin{array}{l}\text { one- } \\
\text { cost) }\end{array}$ & 5.56 & 5.44 & 5.38 & 5.89 & 4.63 & $=$ & 4.63 \\
\hline Total & . & 129.02 & 126.26 & 124.85 & 136.72 & .107 .61 & $\because$ & 107.59 \\
\hline Other costs & & & & & & & & \\
\hline Harvest custom & & 17.50 & 17.50 & 17.50 & 17.50 & 17.50 & & 17.50 \\
\hline Hauling ${ }^{5}$ & & - & -2 & -. & -- & - & & -- \\
\hline Land ** & & 59.70 & 39.31 & 31.14 & 30.03 & 42.59 & & 22.09 \\
\hline Overheạdtt & & 5.67 & 5.67 & 5.67 & 5.67 & 5.67 & & 5.67 \\
\hline $\begin{array}{l}\text { Management ( } 10 \% \\
\text { nonland costs) }\end{array}$ & of & 15.22 & 14.94 & .14 .80 & 15.60 & 13.07 & & 13.00 \\
\hline Total & & 98.09 & 77.42 & 69.11 & 68.86 & 78.83 & & 58.26 \\
\hline Total & & 227.11 & 203.68 & 193.96 & 205.58 & 186.44 & & 165.85 \\
\hline
\end{tabular}

* Based on the use of dibromo ethane (EDB) at $\$ 6 / 8 a 1,5-g a l / a c r e$ application, and a $\$ 2 / a c r e$ custom charge for application.

'Includes gasoline, grease and ofl ( $13 \%$ of fuel cost), and repairs.

TRepairs and grease ( $40 \%$ of tractor o1l and grease cost).

${ }^{5}$ Assessed at $\$ 2.75$ per dry ton $1 n 1985$ and $\$ 2.95$ per diry ton in 2000 .

*hand cost for all crops was computed at $7 \%$ of the average state farm land price plus real estate tax.

${ }^{t+}$ Depreciation of power and machinery plus $40 \%$ for interest, insurance, taxes, and housing:

Source: Reference 28 
were based on a 5 dry ton per acre yield. The total cost can be expected to increase approximately $\$ 4$ per acre for each additional ton yield above 5 tons. Production costs were held constant in all four land capability classes and were increased from 1977 to 1985 and 2000 at 0.5 percent, compounded annually.

Silvicultural Energy Farm Cultivation. As envisioned in this study, this energy farm would consist of selected, rapidly growing tree species planted close together. The crop would be harvested at appropriate intervals, or rotations, and the succeeding crops would be produced by coppicing (sprouting from stumps). Because most conilers do not coppice, plantings. would be restrictcd in most casee to eelected hardwood species that coppice wèll. Many species can be established by cuttings rather than seedlings and exhibit rapid early growth. On the negative side, most hardwoods do not exhibit good site adaptability. The full productive potential of hardwoods can usually be achieved only on sites that are inherently fertile, well drained, well aerated, and adequately supplied with moisture throughout the growing season.

Intensive crop management would be practiced, including fertilization, irrigation, and weed control. In this regard, energy crop production would be similar to field crop production rather than to conventional forestry.

On the basis of the above criteria, a number of species and species groups may be viewed as candidates for use in silvicultural biomass farms. They include:

(1) Populus spp. (including hybrid poplars)

(2) Amcrican sycamore (Plantanus occidentalis L.)

(3) Red alder (Alnus rubra Bong.)

(4) Eucalyptus (Eucalyptus spp.)'

(5) Swagtgum (Iiquidambar styrariflna T..)

(6) Tulip poplar (Liriodendron tulipifera L.).

(7) Ash (Fraxinus spp.)

(8) Exotic hardwoods.

The development of an annual net return for a silviculture energy farm in each of the 21 selected subbasins was achieved through the integration of yield and production cost parameters associated with these particular species. In a Mitre Corporation report, ${ }^{20}$ ten sites representing a variety of climatic, topographic, and land-use situations, were selected as potential locations for a silviculture energy farm. 
Information from these site-specific studies as shown in Table IV-26 was applied to those subbasins found within reasonable geographic proximity.

Six of the ten sites were representative of preferred site conditions, or of locations where it is believed that plantings might reasonably be placed in the future. These were designated largely on the basis of current land-use patterns and private ownership. The six preferred sites excluded the use of prime agricultural land, public land, or swampland. Four additional sites were chosen to broaden the analytical base by including other land-use options. The Illinois and California sites represented the option of using prime agricultural land for biomass production. Crop production at the California site is 100 percent dependent on irrigation; the Illinois site is not irrigated. The Florida site was chosen to represent the option of using wetlands, and the Mississippi site was selected to entertain the notion of using national forest land (DeSoto National Forest) for biomass production. Each of the ten sites was defined as completely as possible in regard to those characteristics that would influence the logistics and economics of biomass production. These included the proportion of the total site area composed of purchasable (leasable) acreage, usable acreage, wooded acreage, and open acreage; the average slope and surface character of the usable acreage; the length of the growing season (frost-free period) and other climatic characteristics; the estimated level of productivity obtainable during a 6-year rotation period; and the cost of 1 and, labor, fuel, and other materials required for plantation operation.

No attempt was made to assign species to each site, although representative species were designated. In all probability, the use of an array of species at each site would be advisable. The ultimate criterion for species selection will be the ability to produce high yields under the conditions specified by site location. Eucalyptus, for example, is generally susceptible to frost injury and would be suitable only for relatively frost-free sites in the South or Southwest. Other candidates, such as the hybrid poplars, eastern cottonwood, and tulippoplar, are less site-specific and could be used at a wider variety of sites. The choice of a species or group of species for use at any given site will depend on the compatibility of the species with site conditions. Research has not yet progressed sufficiently to justify species designations.

In addition, two site-specific estimates of the annual biomass productivity that could be attained with the representative species were prepared. The estimates for current productivity reflect expected conditions in 1985, whereas the future scenario represents the year 2000 under the assumption that research to increase biomass productivity w111 be successful. These estimates are given in Table IV-27.

The yield reported in Table IV-27 represents both current and future yield potential under intensive management conditions. It is generally recognized that research in this area has only scratched the surface of biomass yield potent1al, especially for energy farms.' Little screening 
Table IV-26

REPRESENTATIVE BIOMASS SPECIES FOR

SELECTED PRODUCTION SITE AREAS

Site

Preferred sites

Wisconsin

Missouri

Louisiana

Georgia

Washington

New England

Agricultural sites

California

I11inois

National forest

Mississippi

Swampland site

Fiorida

\section{Representative}

Species*
1,7

$1,2,1$

$1,2,4,5,7$

$1,2,5,6,7$

1,3

$1,2,7$

$1,4,7,8$

$1,2,7$

$1,2,4,5,6,7$

$4,5,6,7,8$

Key to species

(1) Populus spp. (including hybrid poplars)

(2) American sycamore (rlatanus occldeuldils L, )

(3) Red Alder (Alnus rubra Bong.)

(1) Eucalyptus (Finralyptins spp.)

(5) Sweet gum (Liquidambar Styraciflua L.)

(6) Tulip poplar (Liriodendron tulipifera L.)

(7) Ash (Fraxinus spp.)

(8) Exotic hardwoods

Source: Reference 20 
has been inftiated to designate species or selections within species that have potentially high yields. Virtually no work has been performed on developing preferred high-ylelding hybrids specifically adapted for selected sites. It is entirely reasonable to assume that current yields could be doubled if research were directed toward this end. Future blomass ylelds, therefore, are expected to attain levels of 15 to $20 \mathrm{dry}$ tons per acre-year with the development of improved species and selections and advanced cultural methods.

Table IV-27

PRODUCTIVITY AT SELECTED PRODUCTION SITES
CURRENT AND FUTURE SCENARIOS
(Dry Tons per Acre-Year)

per Acre-Year)

\begin{tabular}{|c|c|c|c|}
\hline \multirow[b]{2}{*}{ Site } & \multicolumn{2}{|c|}{ Productivity } & \\
\hline & Current & Future ${ }^{*}$ & \\
\hline Wisconsin & 5 & 10 & \\
\hline Missouri & 7 & 14 & \\
\hline Loutsiana & 12 & 20 & \\
\hline Georgia & 8 & 16 & $=$ \\
\hline Washington & 10 & 20 & \\
\hline New England & 5 & 10 & \\
\hline California & 13 & 2.2. & \\
\hline Illinois & 8 & 15 & \\
\hline Mississippi & 12 & 20 & \\
\hline Florida & 12 & 20 & \\
\hline$\cdot$ & - & . & \\
\hline
\end{tabular}

Source: Reference 20

Production Costs. No precedent exists for the production of silvicultural biomass for energy by intensive crop management. Therefore, estimated silviculture production costs for each of the 10 sites were developed from a conceptual production design. Neither the design nor the cost estimates based on 1 t are intended as a final analysis: The ultimate design(s) that will be followed if such farms are developed 
will certainly vary in accordance with specific site requirements and the technological developments achieved during the interim in silviculture management, harvest, and transport. A concise summary of the production design will be followed by a site-specific analysis.

A production level of 500,000 wet tons per year was assigned to each. of the ten sites. This amount of biomass is equivalent to 250,000 dry tons per year, assuming a moisture content of 50 percent on a wet weight basis. The source of this biomass production is the intensive culture of closely spaced, rapidly growing hardwoods under short-rotation conditions. Seedlings or cuttings were planted at $4 \times 4$ feet spacings-a planting density of 2,725 plants per acre. A rotation period of 6 years and a productive lifetime of 30 years were assumed, which would allow the harveot of one plant crop and four coppice crups from each planting: before replanting was required. The same level of productivity was assumed for both the coppice and the plant crops.

Land acquisition was accomodated by either long-term lease or direct purchase. Land costs ranged from a low of $\$ 150$ per acre at the Wisconsin site to a high of $\$ 2,860$ per acre at the Illinois site. It was assumed that no more than 10 percent of the usable acres at any given site could be realistically acquired for farm use and that a portion of the nonusable land would also be acquired in any lease or purchase contract. Additional usable land would also be needed for roads, irrigation lanes, and field storage areas. Only the planted and supporting acreage would be cleared and prepared for farm use. Costs for this operation varied between sites according to the proportion of wooded land to open land and were based on published land clearing costs.

Crop management assumed the application of supplenteltal itrigalion water during the first 3 years of irrigation; the annual application of nitrogen, phosphorus, and potassium fertilizers at rates sufficient to prevent nutrient mining at a 60 percent nutrient recovery efficiency; the application of lime during the first year of each rotation; and mechanical weed control twice during the first year of each rotation. Because the potential cost-effectiveness of insect and pest control in silviculture production is undetermined at present, no provision was made for it. Fertilizer is applied by aircraft during the greatest portion of each rotation because the presence of the biomass crop would Impede ground equipment.

The biomass crop is harvested at the end of each rotation by a conceptualized self-propelled harvester that cuts the tree stems near the ground, chips the biomass, and delivers the chips to a wagon towed behind the harvester. Although such a machine is not yet in production, its development is considered imperative to the energy farm concept. The major advantage of this harvester would be the reduction in field traffic that would occur with conventional forest harvesting methods.

The harvested biomass is shuttled to field storage areas to await transportation to the conversion facility, which is presumably located 
near the farm area. Transportation is by truck, which was concluded to be the most convenient and least expensive method of transport currently avallable.

Table IV-28 summarizes the results of the production analysis for each of the 10 sites for both the current and future scenarios. Both estimated yields per acre and production costs are presented. All costs were escalated from 1976 to 1977 dollars at 6 percent and were projected to 1985 and 2000 in 1977 dollars at 1 percent, compounded annually.

Table IV-28

TOTAL SILVICULTURE PRODUCTION COSTS AT TEN STUDY SITES: CURRENT AND FUTURE SCENARIOS

(Dry Tons per Acre-Year) Productivity

\begin{tabular}{|c|c|c|c|c|c|c|}
\hline & & \\
\hline Site & Current & Future & \$/Acre & \$/Dry Ton & $\$$ /Acre & \$/Dry Ton \\
\hline WI & 5 & 10 & 151.65 & 30.33 & 200.14 & 20.14 \\
\hline MO & 7 & 14 & 177.80 & 25.40 & 244.30 & 17.45 \\
\hline LA & 12 & 20 & 245.64 & 20.47 & 338.80 & 16.94 \\
\hline GA & 8 & 16 & 186.24 & 23.28 & 268.00 & 16.75 \\
\hline WA & 10 & 20 & 242.50 & 24.25 & 350.20 & 17.51 \\
\hline $\mathrm{NE}$ & 5 & 10 & 161.40 & 32.28 & 221.30 & 22.13 \\
\hline $\mathrm{CA}$ & 13 & 22 & $440: 96$ & 33.92 & 548.90 & 24.95 \\
\hline IL & 8 & 15 & 336.00 & 42.00 & 400.80 & 26.72 \\
\hline MS & 12 & 20 & 255.60 & 21.30 & 349.00 & 17.45 \\
\hline FL & 12 & 20 & 253.32 & 21.11 & 350.40 & 17.52 \\
\hline
\end{tabular}

Source: Reference 20

Differences in productivity are the main reasons for cost variapions between current and futurc scenarios at the same site and between comparable scenarios at different sites. Costs depend mainly on the number of acres required to produce 250,000 dry tons annually, which in turn depends on productivity: the higher the productivity, the smaller the acreage required to produce a given tonnage of biomass.

The impact of the interrelationship of productivity and land costs on total costs is exemplified in the results estimated for the agricultural 
sites of Illinols and Californla. Exceedingly high land costs in Illinols $(\$ 2,860$ per acre), coupled with moderate productivity, result in I1linols having the highest cost per dry ton of any of the 10 sites. Similarly, high land costs in California have contributed to its having the highest cost per acre of all the sites considered. Only through high productivity has the cost per dry ton in California been reduced to levels slightiy less than those of the Illinols site.

Changes in productivity are reflected in all cost. Items that are determined on the basis of acreage. These cost categorles include irrigation, land lease, land clearing and preparation, planting, and weed control. Cost categories largcly independent of acreage considerations include fertilization, planning, superviston, field support; roads, lnading, and harvecting. Transportatlum may be consldered as falling between the two cost groups; although trucking costs depend to some extent on farm acreage as it affects the average hauling distance, the amount of biomass that has to be hauled is the primary cost determinant. Moreover, certain elements of fertilization costs are controlled by acreage, including the costs of lime and cost of ground application of lime and fertilizer during the first year of each rotation.

\section{Comparison of Conventional Agriculture and Biomass Net Return}

The primary intent of this anlysis was to determine the amount of acreage potentfally avallable for biomass production in 71 subbasins. To do this, the average annual net returns developed for conventional agriculture were compared with the net returns generated for the 13 biomass enterprises. As stated previously, it was assumed thet the agricultural operation generating the largest net return would be the candluale most likely to eapture the acreage under consideration. Several assumptions were made to limit the comparisons to those that were considered economfcally and agriculturally feasible.

In addition, based on their net returns, the oilvicultural, sweet sorghum, and kenaf energy farms were considered as candidates for capturing cropland acreage. Blomass net returns from conventional forestry were excluded because of the period of time and cost required to cstab1ish stands of traditional timber on cropland. Owing to generally poor soils and greater slope, land now supporting commercial forests was nnt. considered adequate for either conventional crops or energy farms dedicaled to opccialty crops. I'te puus quality of rangeland soits also restricts feasible biomass alternatives to a silviculture energy farm.

Table IV-29 summarizes the comparisons of the net returns for conventional crops and biomass production. The set of 72 net returns indicated in the matrix was duplicated for all 71 subbasins in land capability classes I-IV and in the years 1985 and 2000. 
Table IV-29

MATRIX OF CONVENTIONAL AGRICULTURE AND BIOMASS NET RETURN COMPARISONS

\section{Land use types}

\section{Cropland}

\begin{tabular}{|c|c|c|c|c|c|c|}
\hline Row & $\mathrm{x}$ & $\mathbf{x}$ & $\mathbf{x}$ & $\mathrm{x}$ & $\mathrm{x}$ & $\mathbf{x}$ \\
\hline Close-grown & $\mathrm{x}$ & $\mathbf{x}$ & $\cdots \mathbf{X}$ & $\mathrm{x}$ & $x$ & $\mathbf{x}$ \\
\hline Hayland & $\mathrm{X}$ & $\mathrm{X}$ & $\mathbf{X}$ & $\mathrm{x}$ & $\mathrm{x}$ & $\mathbf{x}$ \\
\hline
\end{tabular}

Orchards

Summer fallow

\begin{tabular}{|c|c|c|c|c|c|c|}
\hline Temperature idle & $\mathbf{x}$ & $\mathbf{x}$ & $\mathrm{x}$ & $\mathrm{x}$ & $\mathbf{x}$ & $\mathrm{x}$ \\
\hline $\begin{array}{l}\text { Rotation hay } \\
\text { and pasture }\end{array}$ & $\mathbf{x}$ & $\mathrm{x}$ & $\mathbf{x}$ & $\mathbf{x}$ & $\mathrm{x}$ & $\mathrm{x}$ \\
\hline Open land & $\mathbf{x}$ & $\mathrm{x}$ & $\mathrm{X}$ & $\mathrm{x}$ & $\mathrm{x}$ & $\mathbf{x}$ \\
\hline langeland & & & & & & \\
\hline Pasture & $\mathrm{x}$ & $\mathrm{X}$ & $\mathbf{x}$ & $\mathbf{x}$ & $\mathrm{x}$ & $\mathbf{X}$ \\
\hline
\end{tabular}

Range

Forest 1and

Grazed commercial

Ungrazed

commercial

\begin{tabular}{|c|c|c|c|c|c|c|c|c|c|c|c|c|}
\hline $\begin{array}{l}\text { Food- } \\
\text { Fuel } \\
\text { Row } \\
\text { Crops }\end{array}$ & $\begin{array}{l}\text { Fiel- } \\
\text { Jaly } \\
\text { Row } \\
\text { Crops }\end{array}$ & $\begin{array}{l}\text { Food- } \\
\text { Fuel } \\
\text { Close } \\
\text { Grown }\end{array}$ & $\begin{array}{l}\text { Fuel- } \\
\text { only } \\
\text { Close } \\
\text { Grown }\end{array}$ & $\begin{array}{l}\text { Fuel- } \\
\text { only } \\
\text { Rotation } \\
\text { Hay and } \\
\text { Pasture }\end{array}$ & $\begin{array}{l}\text { Fuel- } \\
\text { only } \\
\text { Hay- } \\
\text { land }\end{array}$ & $\begin{array}{c}\text { Fiber- } \\
\text { Fuel } \\
\text { Grazed } \\
\text { Forest- } \\
\text { land }\end{array}$ & $\begin{array}{l}\text { Fuel- } \\
\text { only } \\
\text { Grazed } \\
\text { Forest- } \\
\text { land }\end{array}$ & $\begin{array}{l}\text { Fiber- } \\
\text { Fuel } \\
\text { Ungrazed } \\
\text { Forest- } \\
\quad \text { land }\end{array}$ & $\begin{array}{l}\text { Fuel- } \\
\text { only } \\
\text { Ungrazed } \\
\text { Forest- } \\
\text { land }\end{array}$ & $\begin{array}{c}\text { Silva- } \\
\text { cultural } \\
\text { Energy } \\
\text { Farm }\end{array}$ & $\begin{array}{c}\text { Sweet } \\
\text { Sorghum } \\
\text { Energy } \\
\text { Farm }\end{array}$ & $\begin{array}{c}\text { Kenaf } \\
\text { Energy } \\
\text { Farm }\end{array}$ \\
\hline
\end{tabular}

Grazed non-

commercial 


\section{Available Acreage--Base-Case Scenarlo in 1985}

In 1985, the amount of acreage potentially available for biomass production is approximately 2.5 million acres. The 13 biomass options combined captured less than 0.3 percent of the total land area of the 71 subbasins. The results of the land availability study for the 1985 base-case scenario are summarized in Table IV-30.

The major penetration occurred in the Mid-Atlantic region, where a food(fiber)/fuel combination for close-grown crops captured 3.2 percent of the region's acreage. Penetration of fuel-only biomass enterprises was limited to a small amount of kenaf in the Arkansas White-Red region. This situation, however, is not unduly surprising. Currently, conventional fuel prices have not attained levels that wuuld pouvlale silpang impetus fui llit use uf ulumass as an energy fieedstock. Also, the research efforts that will be required to achieve major advances in biomass production could not be expected to be brought to fruition by the year 1985.

\section{Available Acreage--Base-Case Scenario in 2000}

Conditions projected for the year 2000, however, evidence a substantial increase in the amount of acreage captured for biomass production. Nearly 280 million acres, or 23 percent of the total 1 and area considered in this analysis, was determined to be potentially available for biomass enterprise. Geographically, the available arreage was concentrated in the Upper Mississippi and South Atlantic Gulf Regions. Large amounts of acreage were also located in the Missouri, the Great Lakes, and the Texas Gulf Regions. The results of the land availability analysis for the scenario in the year 2000 are summarized in Table IV-31.

The majority of available acreage was assigned to a food(fiber)/ fuel combination ( 64 percent), and the balance acreage ( 36 percent) to energy farms. The use of conventional crops in a fllel-nnly configuration failed to capture any acreage. Interestingly, many of the net returns. for this option were found to be negative.

Two biomass options were predominant in capturing available acreage. These were a food(fiber)/fuel combination for close-grown crops and silvicultural energy farms. The results of the analysis indicated that 86 perccint of the acreage deemed available lur buth luel-only and energy farm operations was attributed to silvicultural energy farms. Approximately 70 percent of land available for energy farms comes from land capability Classes III and IV. The remaining land was divided between kenaf ( 9 percent) and sweet sorghum ( 6 percent). All acreage available for a food (flber)/fuel combination was associated with close-grown crops and nearly 75 percent of this 1 and originates in land capability Classes II and III.

The strong position of silvicultural energy farms results from the productivity assumptions made in this analysis. This indicates the 
Table IV -30

AVAILABLE ACREAGE FOR THE 1985 BASE-CASE SCENARIO:

71 SUBBASINS

(Thousands of Acres)

\begin{tabular}{|c|c|c|c|c|c|}
\hline Region & $\begin{array}{c}\text { Food(Fiber) } / \\
\text { Fue1 } \\
\end{array}$ & $\begin{array}{l}\text { Fuel } \\
\text { Only }\end{array}$ & $\begin{array}{l}\text { Energy } \\
\text { Farms } \\
\end{array}$ & Total & $\begin{array}{c}\text { Total as a } \\
\text { Percentage } \\
\text { of } \\
\text { Land Area }\end{array}$ \\
\hline New England & 195 & -- & -- & 195 & 0.5 \\
\hline Mid-Atlantic & 2,038 & -- & -- & 2,038 & 3.2 \\
\hline South Atlantic Gulf & -- & -- & -- & -- & -- \\
\hline Great Lakes & - & - & -- & - & -- \\
\hline Ohio & -- & -- & -- & -- & -- \\
\hline Tennessee & -- & -- & -- & -- & - \\
\hline Upper Mississippi & -- & -- & - & -- & - \\
\hline Missouri : & -- & -- & -- & -- & $\because-\dot{0}$ \\
\hline Arkansas White-Red & -- & -- & 228 & 228 & 0.4 \\
\hline Texas Gulf & - & -- & - & -- & -- \\
\hline Upper Colorado & -- & -- & $-\div$ & $\therefore$ & -- \\
\hline Lower Colorado & -- & -- & -- & -- & -- \\
\hline Pacific Northwest & -- & -- & -- & - & -- \\
\hline Total & 2,233 & -- & 228 & 2,461 & 0.2 \\
\hline
\end{tabular}


Table IV-31

AVAILABLE ACREAGE FOR THE YEAR 2000 BASE-CASE SCCENARIO:

71 SUBBASINS

(Thousands of Acres)

\begin{tabular}{|c|c|c|c|c|c|}
\hline Region & $\begin{array}{c}\text { Food (F1ber) } / \\
\text { Fuel }\end{array}$ & $\begin{array}{l}\text { Fuel } \\
\text { Only } \\
\end{array}$ & $\begin{array}{r}\text { Energy } \\
\text { Farms } \\
\end{array}$ & Total & $\begin{array}{c}\text { Total as a } \\
\text { Percentage } \\
\text { of. } \\
\text { Land Area }\end{array}$ \\
\hline New England & 274 & -- & 1,128 & 1,402 & 3.4 \\
\hline Mid-Atlantic & 9,172 & -- & $6 ; 476$ & 15,648 & 24.4 \\
\hline South Atlantic Gulf & 27,531 & -- & 13,930 & 41,461 & 17.9 \\
\hline Great Lakes & 8,217 & -- & 23,012 & 31,229 & 40.0 \\
\hline Ohio & 10,493 & -- & 10,481 & $.20,974$ & 29.9 \\
\hline Tennessee & 9,863 & -- & 9,036 & 18,899 & $\therefore 32.6$ \\
\hline Upper Mississippi & 45,854 & - & 12,872 & 58,726 &, 36.5 \\
\hline Missour1 & $35,428^{\circ}$ & -- & .951 & 36,379 & 19.9 \\
\hline Arkansas White-Red & 8,620 & -- & 5,229 & 13,848 & 25.8 \\
\hline Texas Gulf & 10,331 & -- & 12,937 & 23,268 & 45.0 \\
\hline Upper Colorado & 1,848 & -- & -- & 1,848 & 2.8 \\
\hline Lower Colorado & 626 & -- & -- & 626 & 1.4 \\
\hline Pacific Northwest & 9,653 & - & 5,203 & 14,856 & 11.5 \\
\hline Total & 177,910 & -- & 101,255 & 279,163 & 22.6 \\
\hline
\end{tabular}


Table IV-32

AVAILABLE ACREAGE IN 1985 AS A FUNCTION. OF A 25 PERCENT INCREASE IN THE PRICE FOR BIOMASS FEEDSTOCK:" 71 SUBBASINS

(Thousands of Acres)

\begin{tabular}{|c|c|c|c|c|c|c|c|}
\hline Region & $\begin{array}{c}\text { Food (Fiber)/ } \\
\text { Fuel }\end{array}$ & $\begin{array}{l}\text { Fuel } \\
\text { Only }\end{array}$ & $\begin{array}{l}\text { Energy } \\
\text { Farms } \\
\end{array}$ & Total* & $\begin{array}{c}\text { Total as a } \\
\text { Percentage } \\
\text { of } \\
\text { Land Area } \\
\end{array}$ & $\begin{array}{l}\text { Increase } \\
\text { Over } 1985 \\
\text { Base Case } \\
\end{array}$ & $\begin{array}{l}\text { Percent } \\
\text { Change } \\
\text { Over } 1985 \\
\text { Base Cass } \\
\end{array}$ \\
\hline New England & 274 & 4,679 & -- & 4,953 & 11.8 & 4,758 & 2,440 \\
\hline Mid-Atlantic & 5,058 & -- & $\cdot-$ & 5,058 & 8.0 & 3,020 & 148 \\
\hline South Atlantic Gulf & 14,598 & -- & 15,712 & 30,310 & 13.1 & 30,310 & $+\cdots$ \\
\hline Great Lakes & 7,347 & -- & -- & 7,347 & 9.0 & 7,347 & $t$ \\
\hline Ohio & 19,981 & -- & 1,720 . & 21,701 & 30.9 & 21,701 & $t$ \\
\hline Tennessee & 5,510 & -- & 2,514 & 8,024 & 13.8 & $.8,024$ & $t$ \\
\hline Upper Mississippi & 50,715 & 12,425 & 1,620 & 64,760 & 40.2 & 64,760 & $\dagger$ \\
\hline Missouri & 35,393 & -- & -- & 35,393 & 19.3 & 35,393 & + \\
\hline Arkansas White-Red & 5,384 & -- & 2,583 & 7,967 & 14.8 & 7,739 & 3,393 \\
\hline Texas Gulf & 6,613 & -- & 2,673 & $9 ., 286$ & 17.9 & 9,286 & + \\
\hline Upper Colorado & 1,312 & -- & -- & 1,312 & 2.0 & 1,312 & $t$ \\
\hline Lower Colorado & 246 & -- & -- & 247 & 0.5 & 247 & $\dagger$ \\
\hline Pacific Northwest & 9,984 & -- & -- & 9,884 & 7.0 & 9,984 & $t$ \\
\hline$\therefore$ Total & $162 ; 416$ & 17,104 & 26,822 & 206,342 & 20.2 & 203,881 & 8,284 \\
\hline . & & & & & & & \\
\hline
\end{tabular}


potential advances that could be realized, given the successful application of research and technology. The dominance of the use of close-grown crop residue may be attributed to three principal factors: both the food and residue components have a high dry weight factor at harvest (average $0.9)$; the residue factors are greater for close-grown crops than for most low-moisture herbaceous crops; close-grown crops have lower opportunity and collection costs than the majority of commodities considered.

The major types of land use absorbed by a silvicultural energy fárm are ungrazed commercial forest land (66 percent) and rangeland (20 percent). The food(fiber)/fuel combination for close-grown crops captured acreage from close-grown crops (32 percent), pastureland (28 percent), and row crops ( 17 percent).

A fundamental. explanalun for the signiticant increase in acreage available for biomass production is an alternation in the pricing parameters. For example, the price offered per dry ton for biomass rose 34 percent between 1985 and 2000. Conversely, a 15 percent average increase in commodity prices was partially offset by a 7.6 percent increment in production costs. Therefore, an increase in available acreage can be expected to the extent that the pricing mechanism can be used to facilitate more cost-effective biomass productions.

\section{Acreage Availability Response to Feedstock Price Changes}

In additon to the base-case srenarin, the competitivc position of al1 13 biomass options was assessed by increasing the price offered per dry ton by 25 and 50 percent in both 1985 and 2000. All other parameters were held constant, These net returns werp then comparod with the nel returns developed for conventional agricultural and forestry production.

Available Acreage in Response tn Price Changes in 1985. $\Lambda 25$ percent price increase for the biomass feedstock in 1985 translates into appruxlmately 206 million acres, or about 20 percent of the total land area available for biomass production. Table IV-32. summarizes the effecte of this price increase on the acreage available for biomass production in 1985 in each of the 13 regions analyzed. This acreage is concentrated in the Upper Mississippi, Missouri, and South Atlantic Gulf regions. As \&videnced in the base case, the majority. of avallable acreage was assigned to a food(fiber)/fuel combination ( 80 percent), and energy farms captured 13 percent of the available land.

The two dominant biomass options for 1985 were a food (fiber)/fuel combination for close-grown crops and a silvicultural energy farm. All acreage available for a food (fiber)/fuel combination was associated with close-grown crops, and 85 percent of the acreage available for energy farms was attributed to silviculture. Approximately 90 percent of the land available for energy farms originated from land capability 
Classes III and IV, and that for a food (fiber)/fuel combination comes predominantly ( 85 percent) from capability Classes II and III.

The major types of land use absorbed by a silviculture energy farm are row crops ( 61 percent) and close-grown crops (20 percent). The food (fiber)/fuel combination for close-grown crops captured land from close-grown crops (35 percent), row crops (29 percent), and pastureland (20 percent).

Available acreage increased from 206 million to 394 million acres as the feedstock price increased to 50 percent more than the base-case level. This acreage constitutes 32 percent of the total land area under analysis. Table IV-33 shows the effects of the 50 percent price increase on available acreage for biomass feedstock in the 1985 base-case scenario for each of the 13 regions studied. The areas of greatest concentration are the South Atlantic Gulf, Upper Mississippi, and Missouri regions. As before, a food (fiber)/fuel combination captured the majority (63 percent) of land potentially available for biomass production, and energy farms accounted for 21 percent of the potential acreage.

Although a food (fiber)/fuel combination for close-grown crops and a silvicultural energy farm captured less acreage, they remain the predominant biomass options. The greatest change in acreage was registered by a fuel-only enterprise on ungrazed commercial forestland. Aithough the fuel-only option is limited to the Great Lakes and Upper Mississippi Regions, it accounts for 16 percent of the available acreage.

Available Acreage in Response to Price Changes in 2000. An increment of 25 percent in the price offered for biomass in the year 2000 increased the amount of available land from 280 million to 446 million acres. This quantity represents 36 percent of the land area considered in this analysis. Table IV-34 summarizes the effects of a 25 percent price increase on the acreage available for biomass production in the year 2000 in each of the 13 regions analyzed. The avallable acreage is located in the South Atlantic Gulf, Upper Mississippi, and Missouri regions.

The most significant finding is that energy farms captured the majority ( 54 percent) of total available acreage, and 44 percent of the available land was assigned to a food (fiber)/fuel combination. A silvicultural energy farm was the dominant energy farm option, accounting for 71 percent of the land allocated to energy farms. Sweet sorghum farms captured 19 percent of energy farm acreage, primartly in the South Atlantic Gulf region. The land-use types captured for a silvicultural energy farm are ungrazed commercial forest land (65 percent) and rangeland (19 percent). The crop net return sensitivity analyses show that the majority of land assoclated with energy farms in the year 2000 was from land capability Classes III and IV.

A food (fiber)/fuel combination for close-grown crops accounced for 76 percent of the land affiliated with combination biomass enterprises. 
Table IV-33

AVAILABLE ACREAGE IN 1985 AS A FUNCTION OF A 50 PERCENT INCREASE -N THE PRICE FOR BIOMASS FEEDSTOCK: 71 SUBEASINS

(Thousands of Acres)

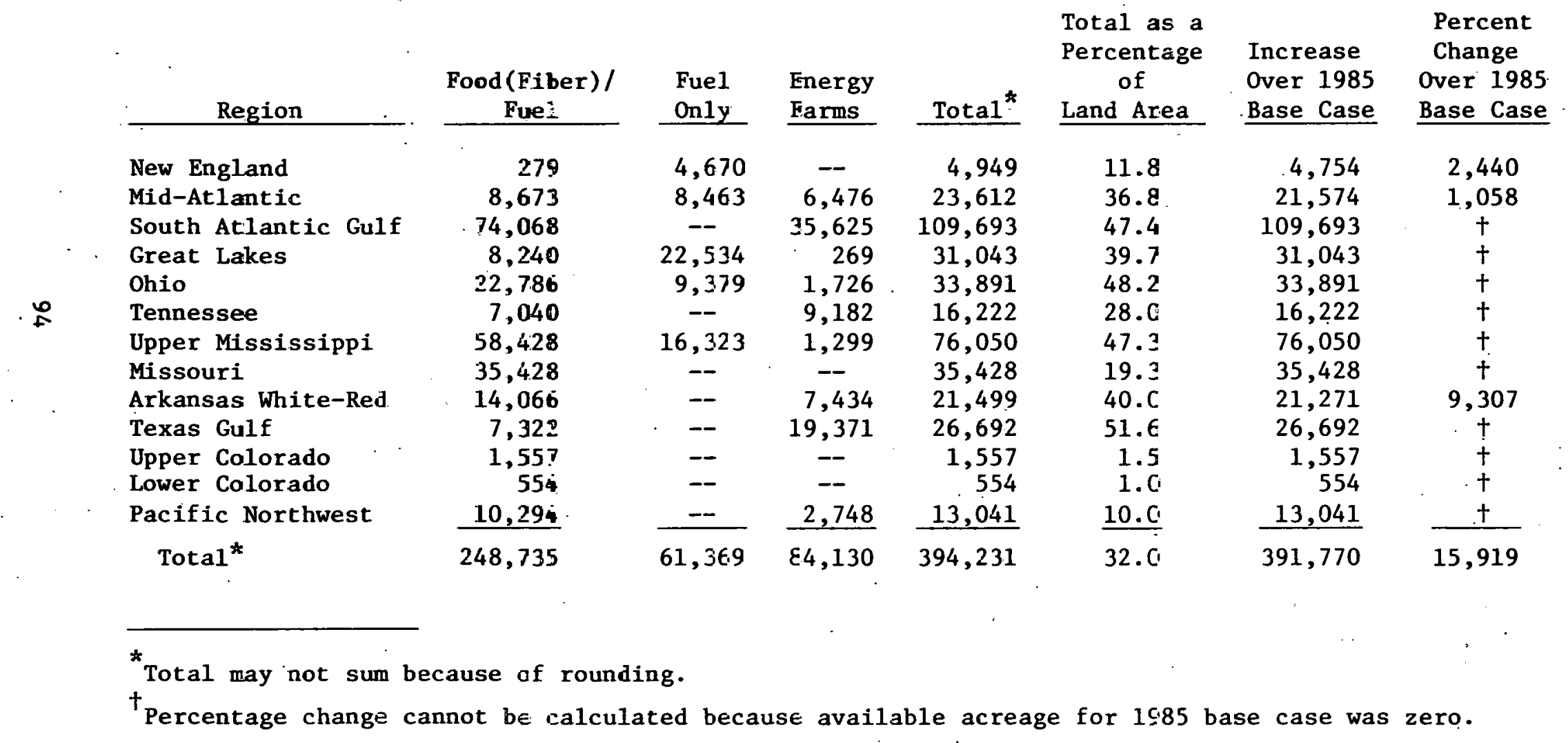


Table IV-34

AVAILABLE ACREAGE IN 2000 AS A FUNCTION OF A 25 PERCENT INCREASE IN THE PRICE FOR BIOMASS FEEDSTOCK: 71 SUBBASINS

(Thousands of Acres)

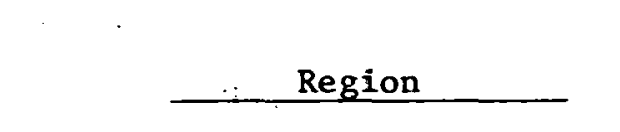

Food(Fiber)/
Fuel

Fue1 Only

New England

Mid-Atlantic

South Atlantic Gulf

Great Lakes

Ohio

in

\section{Tennessee}

. Upper Mississippi

Missouri

Arkansas White-Red

Texas Gulf

Upper Colorado

Lower Colorado

Pacific Northwest

Total ${ }^{*}$

$\begin{array}{r}367 \\ 9,230 \\ 49,217 \\ 3,824 \\ 20,398 \\ 11,378 \\ 46,284 \\ 35,472 \\ 7,736 \\ 8,236 \\ 1,849 \\ 632 \\ 10,001 \\ \hline 204,620\end{array}$

Total as a Percentage of

Land Area

$\begin{array}{r}12.3 \\ 37.7 \\ 54.0 \\ 46.1 \\ 50.4 \\ 37.7 \\ 41.7 \\ 28.6 \\ 45.8 \\ 59.2 \\ 2.8 \\ 1.4 \\ 11.5 \\ \hline 35.6\end{array}$

Percent

Change

Increase

Over 2000

Base Case

Over 2000

Base Case

$$
\begin{array}{r}
3,766 \\
8,558 \\
90,032 \\
4,807 \\
14,436 \\
2,977 \\
8,358 \\
16,059 \\
10,754 \\
7,388 \\
1 \quad 1 \\
6 \\
368 \\
\hline
\end{array}
$$

268

.55

217

15

69

16

14

44

78

32

Neg1

Neg1

$\frac{3}{68}$

* Totals may not sum because of rounding. Neg1.=less than 1 percent. 
Most of this land was drawn from land capability Classes II and III. The land-use types associated with this biomass option are close-grown crops (34 percent), pastureland ( 21 percent), and row crops (17 percent).

The results of a 50 percent increase in the price offered for biomass mirror those evidenced above for a 25 percent price increase. Total available acreage increased to 493 million acres, or about 40 percent of the total land area under consideration. Table IV- 35 presents the effects of this price increase on acreage available for biomass enterprises in the year 2000 in each of the 13 regions studied. This land was concentrated in the South Atlantic Gulf, Upper Mississippi, and Missouri regions.

Energy farms strengthened their position by capturing 73 percent of total available acreage. A silvicultural energy farm remained the most attractive option, although acreage available for sweet sorghum production was double the amount for a 25 percent price increase. The predominant land-use types available to a silvicultural farm are ungrazed commercial forest land ( 64 percent) and rangeland (16 percent).

A food (fiber)/fuel combination for close-grown crops captured 91 percent of the land associated with combination biomass enterprises. The vast majority of the acreage comes from land capability classes II and III. Land affiliated with this biomass enterprise consists of three land-use types: close-grown crops ( 34 percent), pastureland ( 21 percent), and row crops ( 1 ) percent). 
Table IV-35

AVAILABLE ACREAGE IN 2000 AS A FUNCTION OF A 50 PERCENT INCREASE IN THE PRICE FOR BIOMASS FEEDSTOCK: 71 SUBBASINS

(Thousands of Acres)

\begin{tabular}{|c|c|c|c|c|c|c|c|}
\hline Region & $\begin{array}{c}\text { Food (Fiber) / } \\
\text { Fuel } \\
\end{array}$ & $\begin{array}{l}\text { Fuel } \\
\text { Only }\end{array}$ & $\begin{array}{l}\text { Energy } \\
\text { Farms }\end{array}$ & Total ${ }^{*}$ & $\begin{array}{c}\text { Total as a } \\
\text { Percentage } \\
\text { of } \\
\text { Land Area }\end{array}$ & $\begin{array}{l}\text { Increase } \\
\text { Over } 2000 \\
\text { Base Case } \\
\end{array}$ & $\begin{array}{l}\text { Percent } \\
\text { Change } \\
\text { Over } 2000 \\
\text { Base Case } \\
\end{array}$ \\
\hline New England & 289 & 52 & 4,932 & 5,273 & 12.6 & 3,871 & 276 \\
\hline Mid-Atlantic & 10,631 & -- & 15,347 & 25,978 & 40.4 & 10,330 & 66 \\
\hline South Atlantic Gulf & 18,969 & -- & 113,201 & 132,170 & 57.1 & 90,709 & 219 \\
\hline Great Lakes & -- & -- & 46,744 & 46,744 & 59.8 & 15,515 & 50 \\
\hline Ohio & -- & -- & 37,014 & 37,014 & 52.7 & 16,040 & 76 \\
\hline Tennessee & 11,068 & -- & 11,296 & 22,364 & 38.6 & 3,465 & 18 \\
\hline Upper Mississifpi & 41,885 & -- & 54,149 & 96,034 & 50.0 & 37,308 & 64 \\
\hline Missouri & 35,472 & -- & 16,973 & 52,445 & 28.6 & 16,066 & 44 \\
\hline Arkansas White-Red & $5-\overline{107}$ & -- & 25,706 & $\begin{array}{l}25,706 \\
30,663\end{array}$ & $\begin{array}{l}57.1 \\
59.3\end{array}$ & $\begin{array}{r}11,858 \\
7\end{array}$ & $\begin{array}{l}86 \\
32\end{array}$ \\
\hline Upper Colorado & 1,867 & -- & -- & 1,867 & 3.0 & 19 & 1 \\
\hline Lower Colorado & 802 & -- & -- & 802 & 1.8 & 176 & 1 \\
\hline Pacific Northwest & 10,109 & $\underline{=-}$ & 5,223 & 15,332 & 11.6 & 476 & 3. \\
\hline Total & 136,199 & 52 & 356,141 & 492,392 & 36.7 & 213,228 & 76 \\
\hline
\end{tabular}

\footnotetext{
Totals may not sum because of rounding.
} 


\section{REFERENCES}

1. The 011 and Gas Journal--World Wide Issue (December 1978).

2. Soil Conservation Service, "National Inventory of Soil and Water Conservation Needs: 1967" Statistical Bulletin No. 461, U.S. Department of Agriculture (1977).

3. R. K. Ernest et al., "Mission Analysis for the Federal Fuels from Biumass Program," Vol. II: "Missinn Selection Market Penetration Modeling and Economic Evaluation," SRI Internationa, Menlo Park, California (December 1978).

4. S. R. Chapman, Crop Production, W: H. Freeman and Company, San Francisco, California (1976).

5. Dr. Klaus, Iowa State University, Department of Agricultural Economics, personnel communication (December 1978).

6. Economic Research Service, "Economic Indicators for the Farm Production Sector at the Core Projections Program: Scenarios for 1985, 1990 and 2000," U.S. Department of Agriculture (undated).

7. Economic Research Service, "Interregional Agricultural Projections System," Revision II: "Populatinn," U.S. Department of Agriculture (undaled).

8. Economic, Statistic, and Cooperative Services, "Firm, Enterprise Data System," Commodity Economics Division, in cooperation with Oklahoma State University, Stillwater, Oklahoma (U.S. Department of Agriculture) (undated).

9. Bureau of Land Management, "Public Land Statistics," U.S. Department of the Interior (1971).

10. U.S. Foroct Service, "The Nation's Range Resuriles--A Fulesl=Range Envirnnmental Study," Forest Service Report No. 19, U.S. Department of Agriculture (December 1972).

11. F. B. Morrison, Feeds and Feeding, Morrison Publishing Company (1954).

12. G. Evans, Soil Conservation Service, personal communication (April 1979).

13. U.S. Forest Service, "Forest Statistics of the United States, 1977," U.S. Department of Agriculture (1978). 
14. U.S. Forest Service, "The Outlook for T1mber In the United States," U.S. Forest Serv1ce Report No. 20, U.S. Department of Agriculture (October 1973).

15. R. B. Phelps, "The Demand and Price S1tuation for Forest Products 1976-1977," U.S. Forest Service, Miscellaneous Publication No. 1357, U.S. Department of Agriculture (December 1977).

16. U.S. Forest Service, "Index of Hädwood and Softwood Stumpage Prices in the Contiguous States by Timber Supply Region with Projections of Equilibrium Prices. to 2030," U.S. Department of Agriculture (undated).

17. F. A. Schooley et al., "An Evaluation of the use of Agricultural Residues as an Energy Feedstock," Vol. I, SRI Project 3520, SRI International, Menlo Park, California (July 1976).

18. F. S. Schooley et al., "Mission Analysis for The Federal Fuels from Biomass Project," 7 Volumes, prepared for the Department of Energy, SRI International, Menlo Park, California (January 1979).

19. K. A. Miller and F. A. Schooley, "Availability and Cost of Agricultural and Muricipal Residue for use as Alcohol Fuel Feed," SRI Project No. 7734, SRI International, Menlo Park, California (December 1978).

20. K. Howlett and A. Gamache, "Silvicultural Blomass Farms: Forest and Mill Residues as Potential Sources of Blomass," Volumes I-VI, Mitre Technical Report No. 7347, Mitre Corporation, McLean, Virginia (May 1977).

21. D. L. Williams, "Converting Factors for Southern Pine Products," U.S. Forest. Service Bulletin No. 626, U.S. Department of Agreculture (May 1968)..

22. JPR Associates, "The Feasibility of Gencrating Elcctricity in the State of Vermont Using Wood as a Fuel: A Study," JPR Associates, Stowe, Vermont (1975).

23. E. H. Hall et al., "Comparison of Fossil and Wood Fuels," Battelle Columbus Laboratories, Columbus, Ohio (1975).

24. J. A. Alick, Jr., and R. E. Inman, "Effective Utilization of Solar Energy To Produce Clean Fuel," NSF Grant No. 38723, SRI Project 2643, Stanford Research Institute, Men1o Park, California (June 1974).

25. E. S. Lipinsky et a1., Sugar Crops as a Source of Fuels, Vol. I: "Agricultural Research," Battelle Laboratories, Columbus, Ohio (July 31, 1978).

26. J, J. Higgins and G. A. White, "Effects of Plant Population and Haivest Date on Stem Yield and Growth Components of Kenaf in Maryland," Agronomic Journal, 02:667-668 (1970). 
27. N. A. Minton, W. C. Adamson, and G. A. White, "Reaction of Kenaf and Roselle to Three Root-know Nematode Species," Phytopathology, Vol. 60, w012 (December 1970).

28. C. A. Moore, "Kenaf: A Potential Pulp Crop," Northern Regional Research Center, Agricultural Research, Science and Education Administration, U.S. Department of Agriculture, Peoria, Illinois (January 1979).

29. G. A. White et al., "Cultural and Harvesting Methods for Kenaf," Production Research Report No. 113, Agricultural Research Service, U.S. Department of Agriculture (April 1970). 
This section describes the procedure used to select 10 water subbasins with high potential for biomass production and energy farming. The effort: required comparing energy farm resource requirements with the water resource data and land availability data described in the previous sections. Also included in this section is a description of a subbasin selection model. Construction of the model required calculation of a series of ratios and rating biomass production and evaluation factors for each of the 71 subbasins with excess water supplies.

\section{Summary of Subbasin Selection Procedure}

The seven steps used in the subbasin selection procedure were:

(1) Determine surplus water available through an analysis of aggregated subregion water sources and consumption patterns.

(2) Determine acreage available for biomass farms and energy crop production through a crop rate of return analysis within each subbasin.

(3) Determine and evaluate other quantifiable factors of importance to the future feasibility of the energy farm concept. Such factors included competitive fuel availability, stream quality, and area population density.

(4) Weight all of the factors in the analysis.

(5) Computerize the ranking procedure to allow changes in weights and calculation of the results with various assumed future biomass feedstock prices.

(6) Evaluate the computerized results to consider nonquantifiable factors.

(7) Clearance of the subbasins selected in steps 1 through 6 with the DOE Fuels from Biomass Systems Branch.

Steps 3 through 6 are discussed in the paragraphs that follow.

\section{Selection of Subbasin Evaluation Factors}

Selection of factors for use in evaluating each subbasin's potential for energy farming relied heavily on the data generated during the water availability and land availability analyses, but also considered stream quality, fossil fuel consumption, population density, coal resource availability, and area rainfall factors. The evaluation factors that were used are shown in Table V-l. Land and water factors predominate, 
Table, V-1

FACTOR WEIGHTING WORKSHEET

Factor

Weight

i. Amount of Water Available in the Subbasin for Energy Farms in the Year 2000: Excess subbasin water supply measured at the 80 percent exceedance level and assuming minimum stream flows at 80 percent of USFWS estimated requirements.

2. Amounc of Subbasin Acreage Ava1lable for Dedicaced Energy Farms in the Year 2000: Measured in each subbasin by summing the acreage allocated to the following biomaos options on a net return basis: fuel-only row crops, fuel-only closegrown crows, fuel-only rotation hay and pasture, fuel-only hayland, whole tree chipping from grazed forestland, whole tree chipping from ungrazed forestland, and dedicated and intensively managed silviculture and other energy farms (sweet sorghum, kenaf, etc.).

3. Amount of Subbasin Acreage Available for Combination FoodFuel, Fiber-Fuel Crops: Measured in each subbasin by summing the acreage allocated on a net return basis to foodfuel row crops, food-fuel close-grown crops, fiber-fuel grazed forestland, and fiber-fuel ungrazed forestland.

4. Rcgional Watcr to Land Balance! Mcasurcd for the ycar 2000 in each subbasin by dividing the total amount of excess water available by the sum of the total acreage captured by all biomase options. Regions with more than 2 acre-feet $(652,000$ million gallons) of surplus water avallable per acre per year were equally ranked.

5. Quality of Area Stream Flows: Measured in each subbasin by an analysis of data indicating the percentage of subbasin streams not meeting water quality standards in 1975.

6. Dependence of the Subbasin on Fossil Fuel Sources: Measured - in each subbasin by an analysis of electric power generation fuel sources (fossil fuel consumption totals, excluding nuclear and hydro energy as projected for the year 2000).

7. Potential Labor and Product Demand Pool: Avaliability in each subbasin of a population large enough to sustain a local demand for biomass conversion plant end-products and to staff area energy farms and conversion plants. Measured by an analysis of population density projections for the year 2000 in each subbasin.

8. Coal Resource Avallability (metric tons per year in the subbasin): Mine capacity measure.

9. Area Rainfall: Average rainfall measured in inches for the subbasin. 
but water pollution, area fuel demand, and competition from coal as an alternative source of energy in the area were also considered.

\section{Factor We1ght1ng.}

The welghts assigned to each factor are shown in Table V-1, which is a copy: of the worksheet the staff used in factor weighting. These values were obtalned through an 1terative "Delph1" procedure Involving the flve SRI professional staff members assigned to the profect. A group consensus on welght values was required. Each staff member submitted a written assignment of weight values. These were summarized, and the group discussed the summary results. Using normal Delphi procedures, the staff members rewelghted each factor until a group consensus was achleved.

\section{Subbasin Ranking}

After factor weights had been determined, a computer model was developed to allow rapid calculation of subbasin ranking under various alternative assumptions, weighting variations, and factor mixes. The ranking procedure involved:

(1) Acquiring quantiflable data on each factor for 1985 and 2000. (A few of these data are given in Appendix A.)

(2) Using the computer model to derive a subbasin ranking based on three different blomass price assumptions. Rankings were derived for a base case biomass price of $\$ 27$ per dry ton in 2000 (1977 dollars) and for price increases of 25 to 50 percent. Varying the blomass price increased the net return to the farmer from biomass crops and increased the amount of acreage avallable for blomass crops (Factors 2 and 3 ).

(3) Using the computer model to derive a subbasin ranking based on two different factor mixes. The model was first run with all nine factors. When the exercise was repeated, factor 4 , regional water to land balance, was excluded on the assumption that its effect was adequately quantified in factor 1, water availability, and factors 2 and 3, land avallability.

The results of the two computer runs are shown in Tables $\mathrm{V}-2$ and V-3. As shown, the increase in biomass price obtalned by the energy farmer and the time perfod under consideration have a significant effect on the subbasin rankings, whereas the exclusion of the water to land balance factor has only a minor effect. The relative position of subbasins in the ranking scale are significantly affected by blomass price assumptions and by changes over time in the characteristics of the subbasins. 
Table $\mathrm{V}-2$

SJBBASII RAVKINGS WITH WATER-TO-LAND BALANCE FACTOR (F.r the 25 Top-Ranked Subbasins)

Subbasin

\begin{tabular}{|c|c|c|c|c|c|c|}
\hline \multirow{4}{*}{ Ranking } & \multicolumn{6}{|c|}{ Subbasin } \\
\hline & \multicolumn{3}{|c|}{ Year 1985} & \multicolumn{3}{|c|}{ Year 2000} \\
\hline & Base & $1.25 \mathrm{x}$ & $1.50 x$ & Base & $1.25 x$ & $1.50 x$ \\
\hline & Case & Base & Base & Case & Base & Base \\
\hline 1 & $203^{\circ}$ & 302 & 307 & 602 & 302 & 302 \\
\hline 2 & 302 & 602 & 302 & 505 & 301 & 304 \\
\hline 3 & 306 & 505 & 602 & 302 & 307 & 305 \\
\hline 4 & 204 & 307 & 308 & 205 & 304 & 602 \\
\hline 5 & 304 & 301 & 505 & 307 & 602 & 303 \\
\hline$\epsilon$ & 502 & 502 & 306 & 306 & 306 & 301 \\
\hline 7 & 301 & 306 & 205 & 206 & 303 & 2105 \\
\hline$\varepsilon$ & 201 & 308 & 301 & 502 & 205 & 31) 7 \\
\hline g & 307. & 304 & 204 & 301 & 308 & 2174 \\
\hline 10 & 303 & 303 & $\jmath_{02}$ & 304 & 505 & 5105 \\
\hline 11 & 101 & 701 & 303 & 501 & 204 & 206 \\
\hline 12 & 202 & 305 & 304 & 308 & 309 & 233 \\
\hline 13 & 305 & 205 & 206 & 701 & 502 & 358 \\
\hline 14 & 105 & 506 & $j 01$ & 303 & 501 & 339 \\
\hline 15 & 103 & 206 & 309 & 404 & 206 & 325 \\
\hline 16 & 206 & 103 & 203 & 309 & 305 & 703 \\
\hline $1 ?$ & 102 & 501 & 701 & 601 & 203 & 701 \\
\hline 18 & 1,706 & .703 & 40.4. & 1,702 & 701 & 601 \\
\hline 19 & 205 & 803 & 506 & 506 & 506 & 1,706 \\
\hline 20 & 308 & 101 & 601 & 7.02 & 404 & 1,705 \\
\hline 21 & 502 & 702 & 305 & 1,705 & 601 & 501 \\
\hline 22 & 505 & 309 & 803 & 103 & 702 & 702 \\
\hline 23 & 501 & 1,705 & 103 & 305 & 803 & $5 \div 2$ \\
\hline $2 \dot{4}$ & 309 & 503 & 1,702 & 503 & 1,705 & 803 \\
\hline 25 & 1,705 & 105 & 703 & 204 & 802 & 103 \\
\hline
\end{tabular}


Table V-3

SUBBASIN RANKINGS WITHOUT WATER-TO-LAND BALANCE FACTOR (For the 25 Top-Ranked Subbasins)

\begin{tabular}{|c|c|c|c|c|c|c|}
\hline \multirow[b]{3}{*}{ Ranking } & \multicolumn{6}{|c|}{ Subbasin } \\
\hline & \multicolumn{3}{|c|}{ Year 1985} & \multicolumn{3}{|c|}{ Year 2000} \\
\hline & $\begin{array}{l}\text { Base } \\
\text { Case }\end{array}$ & $\begin{array}{l}1.25 \mathrm{x} \\
\text { E.ase }\end{array}$ & $\begin{array}{l}1.50 x \\
\text { Base }\end{array}$ & $\begin{array}{l}\text { Base } \\
\text { Case }\end{array}$ & $\begin{array}{l}1.25 x \\
\text { Base }\end{array}$ & $\begin{array}{l}1.50 x \\
\text { Base }\end{array}$ \\
\hline 1 & 203 & 302 & 302 & 205 & 302 & 302 \\
\hline 2 & 302 & 602 & 205 & 602 & 301 & 304 \\
\hline 3 & 306 & 505 & 307 & 505 & 304 & 306 \\
\hline 4 & 204 & 307 & 301 & 302 & 306 & 303 \\
\hline 5 & 304 & 301 & 602 & 307 & $307^{\circ}$ & 301 \\
\hline 6 & 602 & 701 & 306 & 206 & 303 & 205 \\
\hline 7 & 301 & 502 & 303 & $701^{\circ}$ & 205 . & 602 \\
\hline 8 & 201 & 306 & $304^{\circ}$ & 306 & 602. & 305 \\
\hline 9 & 307 & 506 & 308 & 404 & 505 & 703 \\
\hline 10 & 303 & 803 & 505 & 502 & 305 & 307 \\
\hline 11 & 101 & 308 & 803 & 301. & 309 & 505 \\
\hline 12 & 202 & 703 & 204 & 304 & 308 & 701 \\
\hline 13 & 305 & 304 & 206 & 501 & 701 & 206 \\
\hline 14 & 105 & 303 & 502 & 506 & 506 & 204 \\
\hline 15 & 103 & 1,202 & 701 & 308 & 803 & 803 \\
\hline 16 & 206 & 802 & 506 & 702 & 204 & 309 \\
\hline 17 & 102 & 702 & 309 & 303 & 502 & 802 \\
\hline 18 & 1,706 & 305 & 305 & 801 & 802 . & 203 \\
\hline 19 & 205 & 205 & 802 & 309 & 206 & 308 \\
\hline 20 & 308 & 503 & 501. & 601 & 404 & 702 \\
\hline 21 & 502 & 206 & 404 & 305 & 501 & 801 \\
\hline 22 & 505 & 103 & $703^{\circ}$ & 503 & 1,202 & 1,202 \\
\hline 23 & 501 & 501 & 203 & 803 & 801 & . 704 \\
\hline 24 & 309 & 901 & 1,202 & 1,702 & 702 & 601 \\
\hline 25 & 803 & 101 & 503 & 1,202 & 503 & 502 \\
\hline
\end{tabular}




\section{Evaluation of the Model Results}

After the computerized modeling task had been completed, SRI eva1uated the results to take into consideration nonquantifiable factors and to provide a broadly based geographical survey of water subbasins. This evaluation was conducted in cooperation with the DOE Biomass Energy Systems Branch, and such factors as the following were considered:

- The need to diversify the selection of subbasins to provide study results reflecting a variety of regional environmental conditions

- The need to evaluate areas where large fuels from biomass demonscracion projects are platuled or in progress

- The need to consider such factors as precipitation variability, land fragmentation, and proposed regional land reclamation projects

On the basis of this evaluation of nonquantifiable factors and the results of the computerized model ranking, the subbasins shown in Table $\mathrm{V}-4$ were selected for on-site survey by the SRI study team. 
Table V-4

SUBBASINS SELECTED FOR ON-SITE SURVEY BY SRI

\begin{tabular}{|c|c|c|}
\hline ASR* & 101 & $\begin{array}{l}\text { Maine } \\
\quad \text { (Northern Maine) }\end{array}$ \\
\hline ASR & 206 & $\begin{array}{l}\text { N. Virginia and W. Maryland } \\
\text { (Potomac) }\end{array}$ \\
\hline ASR & 302 & $\begin{array}{l}\text { S. Carolina and W. North Carolina } \\
\text { (Pec - Dec - Edisto) }\end{array}$ \\
\hline ASR & 304 & $\begin{array}{l}\text { N. Florida and S. Georgia } \\
\text { (St. Johns - Survance) }\end{array}$ \\
\hline ASR & 306 & $\begin{array}{l}\text { S.W. Georgia } \\
\quad \text { (Appalachicola) }\end{array}$ \\
\hline ASR & 404 & $\begin{array}{l}\text { E. Michigan } \\
\text { (Eastern Lake Michigan) }\end{array}$ \\
\hline ASR & 602 & $\begin{array}{l}\text { N. Alabama and S. Central Tennessee } \\
\text { (Lower Tennessee) }\end{array}$ \\
\hline ASR & 701 & $\begin{array}{l}\text { Minnesota } \\
\text { (Mississippi Headwaters) }\end{array}$ \\
\hline ASR & 1101 & $\begin{array}{l}\text { N. Aikausas aid S. Migsouri } \\
\text { (Upper White) }\end{array}$ \\
\hline ASR & 1702 & $\begin{array}{l}\text { N.E. Oregon and E. Washington } \\
\text { (Upper/Middle Columbia) }\end{array}$ \\
\hline
\end{tabular}


THIS PAGE

WAS INTENTIONALLYY LEFT BLANK 


\section{SUBBASIN DESCRIPTIONS}

This section describes important characteristics of the 10 subbasins chosen as sites for fieldwork during the study. The purpose of the summaries is to provide factual information that will be useful in evaluating each subbasin's potentlal to support biomass production and future energy farms.

In all cases, summary information on agricultural factors, as well as on land, water, economic, and energy factors, is included as general background for comparing subbasins. We specifically examined soil type, climatic conditions, soil characteristics, farm size, crop characteristics, and land costs and uses for each subbasin. Water availability characteristics and future water requirements were assessed, and economic factors such as earnings, employment, and available agricultural work force were also determined. In addition, potential energy demand and supply were examined through an analysis of current and projected demand, production capacity, and requirements for electric power. The prospects for establishing energy farms and biomass production for use in conversion to useful fuels are summarized for each subbasin.

\section{Subbasin 101--Maine}

Subbasin 101 incorporates almost the entire state of Maine and a small portion of the northeastern part of New Hampshire. The land surface of this basin is 32,300 square miles, or 20.7 million acres. Forestland is predominant, accounting for 90 percent $(18.6$ million acres) of the land area. Farmland comprises about 7 percent ( 1.5 million acres) of the area.

\section{Agricultural Factors}

The most common soil type in Subbasin 101 is Podzol. In Podzol soils, the surface humus horizon (02) is generally thin to moderately thin, the Al is thin or missing, the bleached eluviated horizon (A2) is strongly developed, and the horizon of illuviation (Bhir) is conspicuous, usually dark brown to reddish brown, and often cemented or indurated. Organic compounds, together with iron oxides, serve as cementing agents. In many cases the accumulation of humus in the $B$ horizon produces a secondary organic matter maximum. The fixture of all the horizons except the superficial surface layers is often sand.

Long winters and short, cool summers mark the Podzol zone. Soil moisture is plentiful, because of low evaporation. Annual precipitation 
ranges between 32 and 48 inches, and the frost-free period averages 120150 days par year.

Farmland in Subbasin 101 suffers from misuse that leads to soll erosion and infertility. According to a recent U.S. Soll Conservation Service study, farmland in this subbasin is losing soll at an estimated rate of 6 tons per acre per year, twice the rate acceptable by U.S. Department of Agriculture (USDA) criteria.l The major cause of this loss is the steepness of the slopes of farmland in the subbasin crop. Other causes include long slopes, poor rotations, and up and down hill. planting.

Since 1940, the trend toward specializcd commereial fatils, larger farm units, less total farmland acreage, and more intensive farming has continued at an accelerating rate. By 1974, four commodities (potatoes, egg3; broflers, and inllk) accounced for about 80 percent of the subbasin's total cash farm income. Apples, blueberries, and cattle accounted for another 10 percent. Between 1940 and 1978, the number of farms in the subbasin decreased dramatically, from 39,000 to less than 8,000; cropland acreage decreased from 4.2 million acres to 1.5 million acres; subsistence and part-time farmers decreased from about 18,000 to 1,000 or less; the total number of dairy farms decreased by 95 percent; acreage in hay decreased by 700,000 acres; acreage in vegetables decreased by nearly 13,000 acres; and the number of vegetable farms declined by about 3,700. The forces leading to such changes have included improved transportation systems, changing production technology, and increasing competition from highly productive areas.

\section{Land Factors}

Farmland in Subbasin 101 is predominantly held as small family farms. The average farm is 230 acres, and only 198 farms (2.6 percent of the total) are larger than 1,000 acres. Farmland costs have hepn stoadily increasing. Land costs rose from $\$ 334$ per acre in 1974 to $\$ 484$ per acre in 1978, an increase of 44 percent. This is slightly lese than the 46 percent average increase registered for all 10 subbasins.

Subbasin 101 has almost no federally owned land. However, large tracts of commercial timberland are held by private owners. Approximately 6.6 million acres of commercial timberland is controlled by 10 companies. The largest of these companies are listed in Table VI-1.

The 1977 Energy Research and Development Administration (ERDA) Solar Assessment Study ${ }^{3}$ guidelines suggest that land requirements for a biomass farm that produces 250,000 dry tons/year range from 18.75 square miles $(12,000$ acres ) to 47 square miles $(30,000$ acres). In addition, to facililate management and transportation, the biomass farm should be composed of large parcels within a 50-mile radius held by no more than five separate owners. Given the distribution of land resources in Subbasin 101, the establishment of an energy farm on existing farmland that conforms to these guidelines would be difficult. Conversely, sufficient commercial 
timberland might be avallable. Although the establishment of silviculture energy farms in Subbasin 101 seems appropriate, further investigation of such areas as management and economics would be required.

Table VI-1

PRIVATE OWNERSHIP OF COMMERCIAL TIMBERLAND IN SUBBASIN 101

\begin{tabular}{lrr}
\multicolumn{1}{c}{ Company } & & \multicolumn{1}{c}{ Acres } \\
Great Northern Paper Co. & $2,100,000$ \\
International Paper Co. & $1,150,000$ \\
Scott Paper Co. & & 285,000 \\
Diamond International & & 791,000
\end{tabular}

Source: Reference 2

\section{Water Factors}

Permits are not required, and the state imposes no charges for the use of water for agricultural purposes in Subbasin 101. Riparian water rights are in effect, and no guidelines govern ground-water withdrawal. Water quality is high in this subbasin: 95 percent of all streams meet water quality standards. Owing to the decline in agriculture, the incremental fertilizer burden to streams is only 6 pounds per acre. The incremental fertilizer burden reflects the average rate (in pounds per acre) of application of phosphorous and nitrogen to a currently uncultivated acre for biomass production. No compacts govern water use in Subbasin 101, but the U.S.-Canadian compact governing the Great Lakes and the St. Lawrence River does affect this subbasin. Projected water requirements for energy generation are quite low, reaching only 8 million gallons per day by $2000 .^{4}$ This will have no noticeable effect on available supply.

\section{Economic Factors}

Total earnings in Subbasin 101 in 1975 were $\$ 2.5$ billion. Manufacturing accounted for 30 percent ( $\$ 775 \mathrm{million}$ ), whereas agricultural earnings were only 6 percent ( $\$ 150 \mathrm{mlilion}$ ) of the total. Total earnings for the period 1975-2000 are expected to increase by 107 percent, whereas agrlcultural earnings are projected to increase only 12 percent over the same perfod (in constant dollar terms). 5 
Agricultural employment in 1975 accounted for 17 percent of the subbasin's total employment. Hired farm labor accounted for 87 percent of agricultural empioyment; and owner-operators accounted for 13 percent.

\section{Energy Supply and Demand}

Electric energy demand is projected to increase from 6,300 gigawatthours in 1985 to 18,000 gigawatt-hours in 2000, an increment of 190 percent. 5 The amount of energy provided by fossil fuels is expected to increase from 10 percent of electric power generation in 1985 to 20 percent by 2000 . Conversely, the proportion of electricity generated. from nuclear power will decline from 82 to 70 percent over the same period.

Three utilities in Subbasin 101 can be expected to provide a significant portion of this energy. They are Bangor Hydro-Electric Co., Central. Maine Power Co., and Maine Yankee. Current generating capacity of these three utilities in 1975 was $12,586 \mathrm{gWh} .{ }^{6}$ Projected short-term increases in electric energy demand can be supplied by current energy sources. However, additional generating capacity will be required to fill the long-term projected demand.

\section{Suminary}

The prospects for the establishment of energy farms in Subbasin 101 are mixed. The absence of large tracts of agrlcultural land, together with a declining agricultural economy, discourages the development of new crop-based energy farms. However, large tracts of commerclal timberland exist in this subbasin, and water resource issues will not impede the formation of silviculture energy farms because water is abundant and water quality is very high. The development of cost-effective biomass enterprise may help to meet projected increases in electric energy demand, and biomass could also be used to supply other valuable fuels, such as methane and methanol.

Subbasin 206--Northern Virginia and Western Maryland

Subbasin 206 (Potomac) Includes all of Northern Virginia and Western Maryland, and portions of southern Pennsylvania and western West Virginia. There are approximately 17,031 square miles (10.9 millinn acres) nf land in the Potomac subbasin. Forest land is predominant, accounting for 47 percent ( 5.1 million acres) of the subbasin's land surface. Farmland occupies 21 percent (2.3 million acres) of the area, and pastureland occupies 14 percent ( $1: 5$ million acres).

\section{Agricultural Factors}

The most common soil type in Subbasin 206 is Gray-Brown Podzolic. In this soil, the Al horizon is comparatively thin (2-6 inches). The 
light-colored eluviated zone (A2) is well developed, varying from grayish to yellowish brown. The horizon of the illuviation (B), which is conspicuous because of its varying color, is generally darker than either the parent material or the overlapping horizon, and its texture is also finer.

Soils of this type are of moderate fertility, having suffered considerable leaching and varying losses from erosion. The solum is acid throughout, and base saturation of some horizons may be less than 50 percent. The humus content is medium to low. Annual precipitation ranges from 32 to 48 inches, and the frost-free period averages $180-210$ days per year.

The trend in the area has been toward more commercialized farms, larger farm units, less total farmland acreage, and increased farm income. From 1969 through 1974 the number of farms declined 7 percent, farmland acreage declined 6 percent, but total farm income from products sold rose 68 percent. ${ }^{7}$ The 1974 Census of Agricultural Reports ${ }^{8}$ shows that farm income from products sold totaled more than $\$ 630$ million for counties in this subbasin. Livestock income accounted for 71 percent ( $\$ 450$ million), crop income for 29 percent ( $\$ 180$ million), and forest products for 4 percent ( $\$ 2.3$ million). Crop income increased most, 109 percent over 1969 figures. This increase is largely attributable to increases in the price of corn, wheat, and soybeans.

\section{Land Factors}

Farmland in the Potomac subbasin is concentrated in sma11, family holdings. The average farm in 1974 was 219 acres, and only 460 farms, or 3.2 percent of the total, exceeded 1,000 acres. These larger parcels were distributed throughout the basin, although a slight concentration does occur in West Virginia. Farmland costs in the Potomac subbasin are the highest in the 10 subbasins surveyed. Land costs increased from $\$ 757$ per acre In 1974 lo $\$ 1,110$ per acre lil 1978, ut 46 perceul. The iale of increase is equal to the average rate for all 10 subbasins.

Subbasin 206 includes approximately 1.2 million acres of federally owned 1and, 75 percent of it in the George Washington National. Forest and 25 percent in the Shenandoah National Park. Commercial forestland in the Potomac subbasin is characterized by privately owned holdings of relatively small size. Silviculture may never become a significant industry in this subbasin because of the diversity of land ownership and the lack of the large single-owner parcels that are necessary for economical management and harvesting.

\section{Water Factors}

The states impose no charges for the use of water for agricultural purposes in Subbasin 206. Riparian water rights are in effect for 
properties containing a surface-water source. A permit is required to extract ground water. A nominal fee is charged, and the well must be inspected upon completion. No state or Subbasin legislation controls the use of ground water, and disputes are adjudicated by case law.

Flooding and erosion problems are significant near stream headwaters, and during drought periods, reduced water supplies result in extensive saltwater intrusion. In general, water quality is very high: 90 percent of all streams meet water quality standards. However, the incremental fertilizer burden that could be expected from a biomass enterprise is high ( 38 pounds per acre), and this could present a significant problem in the future. A compact exists between the states of Maryland, Virginia, West Virginia, and Pennsylvania for the formation of a Potomac Valley Conservation District and for the study of and recommending of standards for water pollution and sewage disposal within the district.

Projected water requirements for energy generation are expected to decline from 583 million gallons per day in 1985 to 353 million gallons per day in $2000 .^{4}$ This projected decline will reduce water demand for energy from 4 percent of the available supply in 1985 to 3 percent in 2000.

\section{Economic Factors}

Total earnings for Subbasin 206 in 1975 were $\$ 24.7$ billion. Manufacturing accounted for 8 percent ( $\$ 2.0$ billion), whereas agricultural earnings were only 2.5 percent ( $\$ 630$ million) of the total. The majority of earnings result from tourism and the numerous activities associated with the federal government. Total earnings for 1975-2000 are projected to increase by 198 percent, but agricultural earnings are expected to incrcaoc only 28 percent in constant dollars. 5

Agricultural employment in 1975 accounted for only 4 percent of the subbasin's total employment. Hired farm labor was 68 percent of the agricultural labor force, and owner-operators constituted 32 percent.

\section{Energy Supply and Demand}

Electric energy demand is expected to increase from $44,000 \mathrm{gWh}$ in 1985 LU 130,000 $\mathrm{gWh}$ In 2000, an Increment of 190 percent. ${ }^{5}$ Fossil fuels arc cirpcetcd to $3 c r v c$ as the primary feedstock, slthough the proportion of electricity generated from fossil fueis will decline from 70 percent in 1985 to 54 percent in 2000. Conversely, nuclear power is projected to increase its share from 30 percent to 46 percent over the same time period.

The principal utility operating in Subbasin 206 is the Potomac Edison Co. Coal is its predominant feedstock, and it had a generating capacity of $12,334 \mathrm{gWh}$ in 1975.6 Clearly, alternative sources of power must be obtained to fill the large increases in energy demand projected for this subbasin. 


\section{Summary}

Conditions for the establishment of a biomass enterprise are not particularly favorable in Subbasin 206. Most agricultural land is concentrated in small family farms, although some concentration of large farms does exist in West Virginia. Privately owned commercial forestland is held in small parcels. Large amounts of federally controlled forestland are located within this subbasin, but. the availability of these lands for biomass development is uncertain. Whether federally controlled forestland should be used for energy development is a political issue that is outside the scope of this analysis.

Water quality is high in the subbasin, although erosion, flooding, and saltwater intrusion are sometimes problems. Energy demand is projected to increase significantly over current energy generating capacity by the year 2000: The need for additional energy sources is evident. However, the establishment of a biomass enterprise in Subbasin 206 may not be the best alternative means for dealing with the problem.

\section{Subbasin 302--South Carolina and Western North Carolina}

Subbasin 302 (Pee Dee-Edisto) includes nearly the entire state of South Carolina and the southwestern portion of North Carolina. The land area of this subbasin is 42,000 square miles $(26.9$ million acres). Forestland comprises 66 percent ( 17.7 million acres) of the surface area. Cropland accounts for 23 percent ( 3.5 million acres) and pastureland for 6 percent ( 1.6 million acres).

\section{Agricultural Factors}

The predominant soil type in the Southeast is Red and Yellow Podzolic. This soil is characterized by a new accumulation of surface organic matter, a deep horizon of eluviation, and a deep, thick, illuviated horizon in which the high rate of oxidation and hydration of iron produce bright red and yellow colors.

Heavy annual precipitation has accelerated the rate of mineral decay and soil deterioration through erosion loss. In addition, an acid reaction has developed. Rapid decay of organic matter results in only a small humus accumulation. Generally, Red-Yellow Podzolic soils have a low inherent fertility level, but they respond well to fertilization because of their desirable physical properties.

Annual precipitation ranges from 48 to 64 inches, and the frost-free period ranges from 210 to 240 days per year. The major field crops cultivated in this region are corn, soybeans, tobacco, and hay. 


\section{Land Factors}

The farmland in Subbasin 302 is predominantly concentrated in small family farms. The average farm is 201 acres. According to the 1974 Census of Agriculture, of the 36,518 farms in this subbasin, only 1,222 (3.5 percent) were larger than 1,000 acres. The major concentration of farms larger than 1,000 acres occurs in Allendale (24 percent) and Beaufort (29 percent) Counties in South Carolina. Farmland costs have increased from $\$ 482$ per acre in 1974 to $\$ 646$ per acre in 1970 , an increase of 34 percent.

Approximately 2.2 million acres of federally owned land are held in Subbasin 302, in Lhe Nantahala Nacional Forest of North Carolina and the Sumter and Francis Marion National Forests of South Carni ina. Privately owned commercial timberland is held mainly by small land holders.

\section{Water Factors}

Surface and ground water are abundant. In particular, extensive coastal aquifers have large quantities of untapped water. States do not charge for the use of water for agricultural purposes. Riparian rights for surface-water withdrawal are in effect, and restrictions on groundwater withdrawal are minimal. . In North Carolina, a permit is required to construct a well with a capacity greater than 100,000 gallons. Beaufort County, South Carolina, which has special withdrawal problems, is considered a "capacity use" area, and spectal permits are required there.

Water quality is moderate: 30 percent of the streams in Suhhasin 302 do not meet water quality standards. The projected additional fertilizer burden from a biomass enterprise is 32 mounds per acre. This rel.ntively large quantity could aggravate an existing water quality problem. Subbasin 302 has no water compacts.

Water requirements for energy generation are projected to increase from $2 . \%$ million gallons per day in 1985 to 3.6 million gallons per day in the year $2000 .{ }^{4}$ These values represent 9 percent of available supply in 1985 and 12 percent in 2000. These requirements are the largest of those in the 10 subbasins.

\section{Economic Factors}

Total earnings for Subbasin 302 in 1975 were $\$ 21.4$ billion. Manufacturing accounted for 37 percent ( $\$ 7.8$ million) of total earnings, whereas agricultural earnings were 3 percent (630 million): Total earnings for 1975 through 2000 are predicted to increase by 158 percent. Manufacturing earnings are expected to increase 142 percent, but agricultural earnings are projected to increase only 15 percent from 1975 to 2000 in constant dollars. 5 
Agricultural employment accounted for approximately 10 percent of total employment in 1975: Hired labor accounted for 73 percent of agricultural labor, and owner-operators for 27 percent.

\section{Energy Supply and Demand}

Electric energy demand is expected to increase from $130,000 \mathrm{gWh}$ in 1985 to $330,000 \mathrm{gWh}$ in 2000 , an increment of 160 percent. The contribution of nuclear power is expected to increase from $83,000 \mathrm{gWh}$ ( 60 percent) in 1985 to $243,000 \mathrm{gWh}$ (73 percent) in 2000.5 Although the quantity of electricity generated from fossil fuels will increase from $40,000 \mathrm{gWh}$ in 1985 to $86,000 \mathrm{gWh}$ in 2000, its contribution to electric power generation will decline from 32 percent to 26 percent during that period.

Two utilities currently operate in Subbasin 302, Duke Power Co. and South Carolina Electric and Gas Co. Coal is the predominant feedstock for both utilities ( 80 percent); the remainder of their power comes from oil and natural gas. Generating capacity was $123,000 \mathrm{gWh}$ for both utilities in 1975.6 Given projected electric energy demand in the subbasin, additional generating capacity will be needed to meet both short- and long-term requirements.

\section{$\underline{\text { Summary }}$}

The need for additional energy sources in Subbasin 302 is apparent. Electric energy demand is expected to increase 170 percent over current generating capacity by the year 2000. However, the prospects for a biomass enterprise in Subbasin 302 are mixed. The majority of agricultural land is held in small family farms, although a few countles do have a large percentage of farms in parcels larger than 1,000 acres. Compliance with the 1977 ERDA guidelines could prove to be difficult. The agricultural economy generates a small proportion of the basin's total earnings, and it is projected to increase at a substantially lower rate than either the manufacturing sector or the general economy of the subtisin.

Although water is abundant, water quality is a potential problem. Good planning and operation can mitigate environmental problems if such needs as energy development are determined to take precedence over rigid environmental protection.

Subbasin 302 has a large quantity of federally controlled forestland. However, whether this land will be available is a political question, which must be resolved by legislative and regulatory agency decisions. Privately owned commercial forestland is primarily concentrated in small tracts. If some federally controlled timberland can be set aside for energy farms, the use of biomass to produce useful fuels and chemicals may be a feasible means of helping to meet growing energy demand in the area. 
Subbasin 304--Northern Flortda and Southern Georgia

Subbasin 304. (St. Johns-Suwannee) is composed of Northern Florida and a small portion of South Central Georgla. The land area of this subbasin is 34,800 square miles (22.3 million acres). Forestland is, the major land use type, comprising 63 percent ( 14 million acres) of the land surface. Cropland comprises 13 percent ( 2.9 million acres), and pastureland 10 percent ( 2.2 million acres) of the subbasin's land surface.

\section{Agricultural Factors}

The agricultural characteristics of Subbasin 304 are quite similar to those of Subbasin 302. The predominant soil type is Red and Yellow Podzol1c, and annual precipitation is 48 to 64 inches. The front-free day period is somewhat longer, averaging 240 to 300 days per year. The major farm crops are corn, soybeans, peanuts, and hay.

\section{Land Factors}

Farmland in Subbasin 304 is predominantly concentrated in small family farms. However, the average farm is 413 acres, significantly larger than that in most of the 10 surveyed subbasins: In addition, the average farm in four Florida counties (Dixie, Flagler, Osceola, and Sarasota) was larger than 1,000 acres. Farmland costs have increased 37 percent since 1974 , from $\$ 487$ per acre to $\$ 665$ per acre in 1978 .

Subbasin 304 contains about 1.1 million acres of federally controlled land, mainly in the Usceola and (Mala Natinnal Forests. An equivalont amount of commercial timberland is privately owned. The owners of the largēst of these landholdings are listed in Tab̆le VI- 2 .

Table VI-2

PRIVATE OWNERSHIP OF COMMERCIAL TIMBERLAND IN SUBBASIN 304

\begin{tabular}{lr}
\multicolumn{1}{c}{ Company } & Acres \\
\cline { 1 - 1 } Owners-Illinois & 150,000 \\
St. Joe Paper & 70,000 \\
Buckeye Cellulose & 70,000 \\
I.T.T. Rayonnier & 67,000 \\
Georgla-Pacific Co. & 64,000
\end{tabular}

Source: SRI International 


\section{Water Factors}

The St. John's-Suwanee River Basins are dominated by slow-moving, flat gradient streams, and numerous lakes and wetlands. Generally, this region has ample surface water, although local shortages of surface water do occur during late summer in some locations. Ground water is avallable within 80 feet of the surface in most areas. Abundant supplies are available at greater depths.

State charges are not levied for the use of water for agricultural purposes. As in most subbasins, riparian rights apply to surface water. No legislation governs the use of surface water. Any dispute would have to be adjudicated by case law.

Water quality is modest: 40 percent of this subbasin's streams do not meet water quality standards. The incremental fertilizer burden for a potential blomass enterprise is quite high ( 51 pounds per acre). This increment could serve to aggravate an existing water quality problem. Subbasin 304 has no water compacts.

Water requirements for energy generation are projected to increase from 934 million gallons per day in 1985 to 1,310 militon gallons per day by 2000,4 or 5 percent of available water supply in 1985 and 7 percent of available supply in 2000. This increment will not place an undue burden on water supply.

\section{Economic Factors}

Total earnings for Subbasin 304 in 1975 were $\$ 15.5$ billion. Manufacturing contributed 15 percent $(2.3$ billion) to total earnings, and agriculture accounted for 5 percent ( $\$ 670 \mathrm{million}$ ) of total earnings. Total earnings for 1975 through 2000 are expected to increase by 178 per-' cent. Manufacturing earnings w111 increase 150 percent over the same perfod, but agricultural earnings are projected to increase only 24 percent. 5

Agricultural employment accounted for approximately 9 percent of the subbasin's total employment in 1975. H1red farm labor was 80 percent of total agricultural labor, and owner-operators were 20 percent.

\section{Energy Supply and Demand}

Electric energy demand is projected to increase 240 percent from $1985(110,000 \mathrm{gWh})$ to $2000(380,000 \mathrm{gWh})$. Although the amount of electric power generated from both fossil fuels and nuclear power w111 increase, the relative concentration of these feedstocks ( 70 percent fossil fuels, 30 percent nuclear) is projected to remain constant from 1985 to $2000.6^{6}$ 
Two major utility systems currently generate energy in Subbasin 304 , Florida Power Corporation and Tampa Electric Company. Oil and natural gas are the predominant feedstocks. Total generating capacity (both utilities) in 1975 was $527,266 \mathrm{gWh} .{ }^{6}$ Projected electric energy demand in the area suggests that neither additional generating capacity nor larger purchases of electric power will be needed to satisfy eithểr short- or long-term demand.

\section{Summary}

The prospects for the development of a biomass enterprise in Subbasin 304 are generally favorable. Compliance with the 1977 ERDA guidelines may be possible because the average farm size in several counties exceeds 1,000 acres. In addition, large amounts of both federally controlled and privately owned commercial timberland are found in Subbasin 304 .

Surface and ground water are abundant. Water quality' problems can be minimized with thorough planning and careful operation. Demand for energy is expected to increase substantially between 1985 and 2000 . Although sufficient generating capacity currently exists, electricity could be generated in this subbasin and sold to other areas. The area has an established agricultural base, large holdings of farmland and commercial timberland, the longest crop growing season of the 10 areas surveyed, and considerable potential for biomass production and energy farming.

\section{Subbasin 306--Southwest Georgia}

Subbasin 306 (Apalachicola) incorporates Southwest Geurgia and the central portion of the Florida panhandle. The land surface of this subbasin is 24,000 square miles ( 15.4 million acres). Forestland is predominant, accounting for 70 percent ( 10.7 million acres) of the 1 and area. Farmland occupies approximately 20 percent ( 3.1 million acres), and 8 percent ( 1.2 million acres) of the subbasin is pastureland.

\section{Agricultural Factors}

l'he agricultural characteristics of Subbasin 306 are quite similar to those of Subbasins 302 and 304. The predominant soil type is Red and Yellow Podzolic, and precipitation ranges from 48 to 64 inches. The frost-free period is 240 to 270 days per year. The major farm crops are corn, soybeans, peanuts, and hay'. 


\section{Land Factors}

Farmland in Subbasin 306 is predominantly held in small family farms. The average farm is 340 acres. However, about 9 percent of all farms in this subbasin exceed 1,000 acres. In addition, the area has 70 to 80 land clusters of 25,000 acres or more that could serve as potential sites for a cropland biomass enterprise. ${ }^{9}$ A few of the larger farmland parcels are listed in Table VI-3.

Table VI-3

LARGE FARM PARCELS--ALBANY GEORGIA AREA

\begin{tabular}{ll}
\multicolumn{1}{c}{ Company } & Acres \\
\hline Newberry Farms & 18,000 \\
Tallacre Plantation & 18,000 \\
Blue Springs Plantation & 17,000 \\
Magnolia Plantations \#1, \#2, \#3, \#4 & 15,000 \\
Pinebloom Plantation & 12,000 \\
Jordan Farms & 10,000
\end{tabular}

Source: Reference 9

Land costs increased from $\$ 460$ per acre in 1974 to $\$ 622$ per acre in 1978 , an increase of 35 percent.

Subbasin 306 has approximately 1.3 million acres of federally controlled land, almost entirely in the Apalachicola National Forest (1.1 million acres) and the Chat tahoochee National Forest ( 0.2 million acres). Privately owned commercial timberland consists mainly of fairly small tracts.

\section{Water Factors}

The Appalachicola River Basin is in the Coastal Plain Region and is characterized by rolling hills and narrow river valleys famous for white water canoeing. Surface- and ground-water resources are abundant because of the high precipitation and runoff in the region. In particular, enormous quantities of ground water are available in the extensive aquifers under the coastal plain. Flooding is a problem in some regions, as is erosion and sedimentation. 
No state charges are levied for the use of water for agricultural purposes. Riparlan rights are applied to surface water. No legislation governs the use of surface water, and disputes are adjudicated by case law.

Water quality is modest: 30 percent of all streams in Subbasin 306 do not meet water quality standards. The projected incremental fertilizer burden from a potential biomass enterprise is quite low (13.0 pounds per acre); establishment of a biomass enterprise would therefore not lead to deterioration in existing water quality:

Water requirements for energy generation are projected to decline from 1,345 million gallons per day in 1985 to 973 million gallons per day by 2000, reducing the proportion of available supply from 5 to 4 percent. This subbasin does not have any water compacts. 4

\section{Economic Factors}

Total earnings for Subbasin 306 in 1975 were $\$ 14.4$ billion. Manufacturing contributed 22 percent ( $\$ 3.2$ billion) to actual earnings in 1975 , and agriculture accounted for 4 percent ( $\$ 440$ million). Total earnings for 1975 through 2000 are projected to increase by 183 percent. Manufacturing earnings are estimated to increase by 147 percent over this period, but agricultural earnings are expected to increaise by only 32 percent. 5

Total employment for Subbasin 306 in 1975 was approximately 1.3 million. Agricultural employment accounted for 4.6 percent $(60,000)$. Hired farm labor comprised 66 percent of total agricultural labor, and owner-operators consituted 34 percent.

\section{Energy Supply and Demand}

Electric energy demand is projected to increase from $40,000 \mathrm{gWh}$ in 1985 to $120,000 \mathrm{gWh}$ in 2000 , an increase of 200 percent. Reliance on fossil fuels as an energy feedstock is expected to decline from 72 percent of electric power generation in 1985 to 50 percent by 2000 . Conversely, reliance on nuclear power for electric power generation is projected to increase from 25 percent to 49 percent over the same period. 5

One major utility system (Georgia Power Co.) currently generates electric power in Subbasin 306. This utility, which relies predominanty on fossil fuels, had a generating capacity of $76,000 \mathrm{gWh}$ in 1975.6 . Additional generating capacity will be required in the long run to meet. projected increases in energy demand. 


\section{$\underline{\text { Summary }}$}

The prospects for the establishment of a biomass enterprise in Subbasin 306 are quite favorable. The existence of 70 to 80 cropland clusters of approximately 25,000 acres each is a significant asset and would permit compliance with the 1977. ERDA guidelines. Large tracts of federally controlled forestland are also present, although determining the potential availability of this land 1 s beyond the scope of the present inquiry.

Surface and ground water are abundant. Although water quality is moderate, the projected incremental fertilizer burden from a biomass enterprise is sufficiently low to avoid further declines in water quality. Water requirements for energy generation are declining, which will free increasing water supplies for alternative uses.

The need for additional energy in the subbasin is apparent--electric energy demand is projected to increase 62 percent over current generating capacity. The establishment of a biomass enterprise in Subbasin 306 appears to be a feasible option for increasing energy production.

\section{Subbasin 404--Eastern Michigan}

Subbasin, 404 (Eastern Lake Michigan) incorporates the western half of Eastern Michigan and a small portion of south-central Indiana. The land surface of this subbasin is 22,100 square miles ( 14.1 million acres). Forestland is predominant, accounting for 54 percent ( 7.6 million acres) of the land area. Farmland occupies approximately 37 percent $(5.2$ million acres) of the land surface, and pastureland occupies 4 percent $(0.5$ million acres).

\section{Agricultural Factors}

The agricultural characteristics of this subbasin are a mixture of thosc of the East Coast and of the Midwest. The soil type most commonly found is Gray-Brown Polzolic, the predominant soll type of the Mid-Atlantic region. Annual precipitation is less than it is in most of the 10 subbasins, averaging 16 to 32 inches. The frost-free period is similar to that in the New England area, ranging from 120 to 150 days per year. The major field crops are oats, wheat, hay, and corn.

\section{Land Factors}

Farmland in this subbasin is almost entirely held in small family farms. The average farm in 1974 was 180 acres, and only 314 farms, or less than 1 percent of all farms in the subbasin, exceeded 1,000 acres. Farm size distribution was uniform throughout the subbasin. Farmland costs increased from $\$ 456$ per acre in 1974 to $\$ 752$ per acre in 1978, an increase of 65 percent. This increase significantly exceeds the 46 percent average increase for all 10 subbasins. 
Subbasin 404 has approximately 860,000 acres of federally owned land, all in the Manistee National Forest. Privately owned commercial forestland is held mainly in relatively small tracts.

\section{Water Factors}

The Eastern Lake Michigan basin is characterized by gently rolling hills and generally flat terrain. Localized problems of water supply do exist, and the region is extremely susceptible to droughts. Ground water is lacking in some portions of the region, which are underlain by crystalline rock. In other areas, ground water is being pumped at a faster rate than it is recharged, causing intrusion of poorer quality water or a reduction in the available supply. Water quality is very high: 95 percent of all streams meet water quality standards. The incremental fertilizer burden from an additional acre of cropland use is low (15 pounds per acre), suggesting that water quality standards would not be significantly altered by the establishment of a biomass enterprise.

There is no charge for the use of water for agricultural purposes. Riparian rights are in effect for those properties containing or bordering on a surface water source. This subbasin participates in two water compacts: the Great Lakes Basin compact and the Canadian Boundary Waters Treaty. Subbasin 404 is a signatory of the Great Lakes Basin Compact. The subbasin is subject to the Canadian Boundary Waters Treaty, an international accord between the United States and Canada, because the treaty is intended to monitor surface water on the U.S.-Canadian border, which runs through Subbasin 404 .

Projected water requirements for energy are expected to decline more than 50 percent, from 776 million gallons per day in 1985 to 429 million gallons per day in $2000 .^{4}$ This decline will reduce burden on available supply from 4 percent in 1985 to 2 percent in 2000.

\section{Economic Factor 3}

Total earnings for Subbasin 404 in 1975. were $\$ 14.4$ billion. Manufacturing accounted for 40 percent ( $\$ 5.8$ billion) of total earnings, and agricultural earnings were 4.3 percent ( $\$ 360$ million). Total earnings for the 1975 to 2000 period are projected to increase by 141 percent in constant dollars. Manufacturing earnings are projected to increase by 109 percent, and agricultural earnings are expected to increase by 8 percent. 5

Total employment for Subbasin 404 in 1975 was about 1.3 million. Agricultural employment accounted for 12 percent $(151,000)$ of the subbasin's total. Hired farm labor constituted 72 percent of total agricultural labor, and 22 percent of the labor force were owner-operators. 


\section{Energy Supply and Demand}

Electric energy demand is projected to increase from $53,000 \mathrm{gWh}$ in 1985 to $97,500 \mathrm{gWh}$ by 2000 , an increase of 81 percent. The position of fossil fuels as an energy feedstock is expected to decline from 26 percent of electric power generation in 1985 to 9 percent by 2000 . Conversely, rellance on nuclear power is projected to increase from 74 percent in 1985 to 91 percent by 2000.5

One major utility system, Consumers Power Company, currently gener-. ates electric power in Subbasin 404. This utility, which relies primaily on fossil fuel, had a generating capacity of approximately $46,400 \mathrm{gWh}$ in 1975.6 Given the projected demand for electric power, additional generating capacity will be required to satisfy both near- and long-term demand.

\section{$\underline{\text { Summary }}$}

The need for additional energy sources in Subbasin 404 is apparent. Electric energy demand is expected to increase 110 percent over current generating capacity by the year 2000. However, the prospects for the establishment of a biomass enterprise in Subbasin 404 are generally unfavorable. Almost all farmland is held in small family farms, and less than 1 percent of all farms exceed 1,000 acres. Compliance with the 1977 ERDA guidelines would be difficult. The agricultural economy contributes only a minor portion of the subbasin's total earnings, and it is expected to grow substantially less rapidly than either the manufacturing sector or the economy as a whole.

Although water quality is high, localized problems of water supply do exist, and the region is extremely susceptible to droughts. . These characteristics could constrain the development of a.biomass energy enterprise.

A large amount of federally controlled forestland is found in Subbasin 404. However, the availability of this land for energy development is questionable, as it is in all 10 subbasins. If portions of federally controlled timberland can be devoted to energy farms, the production of needed fuels and chemicals from biomass may be a feasible option.

\section{Subbasin 602--Northern Alabama and South Central Tennessee}

Subbasin 602 (lower Tennessee). is composed of northern Alabama and south central Tennessee. The surface area of this basin is 18,400 square miles ( 11.8 million acres). Forestland is predominant, accounting for 52 percent ( 60 million acres) of the area. Farmland occuples 30 percent (1.8 million acres) of the area. 


\section{Agricultural Factors}

The agricultural characteristics of Subbasin 602 are quite similar to those of the South Atlantic Gulf region. The predominant soll type is Red and Yellow Podzolic. Annual precipitation averages 48 to 64 Inches, and the frost-free perlod ranges from 210 to 240 days per year. The major field crops are soybeans, cotton, and corn.

\section{Land Factors}

Agricultural land is concentrated in small family farms. The average farm in 1974 was 162 acres, the smallest average found in the 10 subbasins. Less than 2 percent of all farms in this subbasin exceed 1,000 acies. Cropland costs have increased from $\$ 382$ per acre in 1974 to. $\$ 569$ per acre in 1978, an increase of 49 percent. This increase is commensurate with the 46 percent average increase registered for all 10 subbasins.

Subbasin 602 contains approximately 56,500 acres of federally controlled land, all of it in the Willlam B. Bankhead National Forest of Tennessee. This is the smallest amount of federal land found in any of the 10 subbasins. Privately owned commercial timberland, like farmland, is held mainly in small parcels.

\section{Water Factors}

The Lower Tennessee River Basin generally has ampleiwater resources to provide for growth while maintaining environmental quality. Ground water, in particular, is an abundant and little used resource. H1scorically, scvcrc flooding along the Tennessee kiver hindered induscrialization of the region. Howcver, the Tennessee Valley Authnrity, r.reated In 1933, has greatly reduced this problem and contributed to the economic attractiveness of the region to induscry. Steam-electrlc plauls aciuulit for the largest water withdrawals in the region. Occasional water shortages do exist in the Lower Tennessee because of conflicts among recreational, hydropower, and industrial requirements.

Water quality is very high: 95 percent of all streams meet water quality standards. The projected incremental fertilizer burden from an addiclonal acre of a bloinass euterprlse 1 s moderate (24 pounds per acra) and would not serlously affect current water quality.

The states impose no charge for the use of water for agricultural purposes. Riparian rights are in effect for those properties containing or bordering a surface water source. This subbasin is a signatory to the Tennessee River Basin Water Pollution Control Compact.

Water requirements for energy use are profected to decline from 3,910 million gallons per day in 1985 to 3,331 million gallons per day by $2000.4^{4}$ This decline w1ll reduce the burden on avallable supply from 9 percent in 1985 to 7 percent in 2000. 


\section{Economic Factors}

Total earnings for Subbasin 602 in 1975 were $\$ 4.0$ billion. Manufacturing accounted for 30 percent ( $\$ 1.2$ billion) of total earnings, and agricultural earnings were 6 percent ( $\$ 240$ million). Total earnings in constant dollars are projected to increase by 191 percent from 1975 to 2000. Manufacturing earnings are estimated to increase by 158 percent, and agricultural earnings are expected to increase 12 percent over the same perlod. 5

Total employment for Subbasin 602 in 1975 was 424,000. Agricultural employment accounted for 18 percent $(78,000)$ of the total. Hired farm labor was. 51 percent of total agricultural labor, and owner-operators represented 49 percent of the agricultural labor force.

\section{Energy Supply and Demand}

Energy demand is expected to increase from $88,000 \mathrm{gWh}$ in 1985 to $150,000 \mathrm{gWh}$ by 2000 , an increase of 72 percent. The use of fossil. fuels as an energy feedstock is projected to increase from 18 percent of electric power generation in 1985 to 26 percent by 2000. Conversely, reliance on nuclear power is expected to decline from 73 percent of total electric power generation in 1985 to 69 percent in 2000.5

Currently no major utility system generates electric power in Subbasin 602. Most of the electric power is purchased from the Tennessee Valley Authority and distributed through municipal systems and rural electric cooperatives.

\section{Summary}

The prospects for the establishment of a cropland energy farm in Subbasin 602 are generally poor, even though water is abundant and water quality is high. Average farm size in this subbasin is the smallest of all 10 subbasins, and less than 2 percent of all farms exceed 1,000 acres. The formation of a silviculture energy farm would also be difficult. Private sector holdings of commerclal forestland are quite small, and the amount of federally controlled forestland in this subbasin is the smallest of all 10 subbasins surveyed. 
Although energy demand is projected to increase approximately 70 percent between 1985 and 2000; no electric utility system is currently operating in Subbasin 602. The absence of a local utility capable of using the biomass feedstock suggests two options. The first is to transport the feedstock to a conversion facility outside the subbasin. However, transportation costs are high and could prove to be prohibitive. The second option is to construct a conversion facility within the subbasin. This is technically feasible, but a detalled economic analysis would be required to determine the cost-effectiveness of this type of venture.

\section{Subbasin 701--Minnesota}

Subbasin 701 (Mississippi Headwaters) incorporates centrai Minnesota and a small portion of western Wisconsin. The land surface of this basin is 44,700 square miles (28.6 million acres). Farmland is the predominant land use type, accounting for 50 percent ( 14.3 million acres) of the land surface. Forestland occupies 35 percent (10 million acres), and 7 percent ( 2 million acres) of the land surface is pastureland.

\section{Agricultural Factors}

The major soil type found in Subbasin 701 is Brunizem (Prairie) soil. This soll group is characterized by a lack of colored surface horizon (A1) that is 6 or more inches thick. The amount of organlc matter decreases with increasing depth, as does the $\mathrm{C} / \mathrm{N}$ ratio. The solum does not have an A2 horizon. The $B$ horizon is a zone of clay accumulation.

Annual precipitation in the subbasin ranges from 16 to 32 inches, with a high percentage falling during the growing seasnn. 'The frost-free perfod averages 120 to 150 days per year. Corn, nats, wheat, soybeans, and livestock are the principal agricultural commodities.

\section{Land Factors}

Farmland in this subbasin is held by small, individual farmers. The average farm in 1974 was $25 /$ acroo. Of the 60,752 fallus lu lle subbasin, less than 2 percent $(1,050)$ exceed 1,000 acres. ${ }^{8}$ These larger parcels are distributed evenly thrnughnut the subbasin. Farmland costs have risen from $\$ 455$ per acre in 1974 to $\$ 1,010$ per arre in 1978, an increacc of 122 percent. 'l'his is the largest increase of all 10 subbasins, and is approximately three times greater than the 10 basin average of 46 percent.

The subbasin contains approximately 340,000 . acres of federa11y controlled land, all in the Chippewa National Forest. Commerclal forestland in the Mississippi Headwaters subbasin is generally held in relatively small parcels. 


\section{Water Factors}

The Mississippi Headwaters are characterized by wetlands, poor drainage, rolling hills, and strealls with flat gradients. Abundant surface and ground water exist, although potable ground water supplies are a problem in some regions underlain by crystalline rock.

There is no state-imposed charge for the use of water for agricultural purposes. Riparian rights are in effect for properties containing or bordering on a surface water source. A permit is required to extract ground water. Two types of permits are issued; a class A permit is issued for a well in an area in which the Commission of National Resources has determined that adequate ground water is available, and a class $B$ permit is issued for wells in all other areas. A $\$ 15$ fee is assessed for either class of permit. Class A permits require 6-12 months from date of application to date of issue. Class $B$ permits usually require more time.

Water quality is very high: 95 percent of all streams meet water quality standards. The incremental fertilizer burden for biomass production is also high ( 59 pounds per acre). A biomass enterprise could thus contribute to a deterioration in water quality. The State of Minnesota has water compacts with Wisconsin and South Dakota that govern all quantity and quality aspects of interbasin water transfer.

Projected water requirements for energy generation are expected to decline from 1,085 million gallons per day in 1985 to 476 million gallons per day by $2000 .{ }^{4}$ This projected decline will reduce the burden on available supply from 9 percent in 1985 to 4 percent in 2000.

\section{Economic Factors}

Total earnings for Subbasin 701 in 1975 were $\$ 15.8$ billion. Manufacturing accounted for 25 percent ( $\$ 3.9$ billion) of total earnings, and agricultural earnings were 5 percent ( $\$ 770$ million). Total earnings for 1975 to 2000 are projected to increase by 154 : percent. Manufacturing earnings are expected to increase by 134 percent over the same period, and agricultural earnings are estimated to increase by 21 percent. 5

Agricultural employment in 1975 accounted for 12 percent of the subbasin's total employment. Hired farm labor represented 56 percent of the total agricultural labor force, and owner-operators constituted 44 percent.

\section{Energy Supply and Demand}

Electric energy demand is projected to increase from $33,000 \mathrm{gWh}$ in 1985 to $47,000 \mathrm{gWh}$ in 2000 , an increase of 42 percent. This is the lowest increase for a11 10 subbasins, Use of fossil fuels as an energy 
feedstock is expected to increase from 87 percent of electric power generation in 1985 to 94 percent by 2000. Conversely, nuclear power as an energy feedstock is projected to decline from 12 percent of electric power generation in 1985 to 6 percent by 2000.5

The major utility system operating in Subbasin 701 is the Northern States Power Company. Fossil fuels are its predominant feedstóck, and this utility had a generating capacity of $41,347 \mathrm{gWh}$ in $1975.6^{\circ}$ 'Although demand for electric power is projected to surpass current generating capacity, the increment may not be sufficient to justify the formation of a biomass enterprise.

\section{Summary}

Conditions for the eslabllshinent of a biomass enterprise in Subbasin 701 are not favorable. Although it has a large agricultural base, most agricultural land is concentrated in small family farms, and less than 2 percent of all farms exceed 1,000 acres. Privately owned commercial forestland is held by individuals in small parcels. Substantial quantities of federally controlled forestland are located in this subbasin, but the ava1lability of these lands is uncertain.

Water quality is high, but the incremental fertilizer burden from an acre of land devoted to biomass production is sufficiently high to contribute to a. deterioration in water quality. Electric energy demand is projected to increase modestly from 1985 to 2000 , but the 1975 gen-. erating capacity of the major utility system in Subbasin 701 can fulfill 86 percent of the projected demand for the year 2000 .

Subbasin 1101*...Northern Arkansas and Souchern Missouri

Subbasin 1101 (Upper White) comprises North-Central Arkansas and South-Central Missouri. The land surface is 22,300 square miles (14.3 million acres). The predominant land use type is forestiand, which accounts for 56 perrent ( 8 milition acres) of the ared. Farmland occupies 30 percent ( 4.3 million acres), and 11 percent $(1.6$ million acres) of the area is pastureland.

\section{Agricultural factors}

The agricultural characteristics of this subbasin are a mixture of those of the South Atlantic Gulf Region and of the Midwest. The predominant soil type is Red and Yellow Podzolic, as it is in the South Atlantic Region. Annual precipitation in Subbasin 1101 averages 16 to 40 inches. The frust-free period is similar to that in the Midwest, averaging 180 to 210 days per year. The major field crops are wheat, soybeans, corn, and sorghum. 


\section{Land Factors}

Agricultural land in this subbasin is also concentrated in small family farms. The average farm is 254 acres, and only 3 percent of all farms exceed 1,000 acres. 8 This distribution is consistent for all counties in the subbasin. Farmland costs have risen from $\$ 284$ per acre In 1974 to $\$ 400$ per acre in 1978. Th1s 41 percent increase is slightly lower than the 10 subbasin average of 46 percent. Approximately 1 million acres of federally controlled land exists in the subbasin, in the Ozark National Forest in Arkansas and the Mark Twain National Forest in Missouri. Commercial timberland, like farmland, is held in small parcels.

\section{Water Factors}

The Upper White River is in the Ozark Mountain region of Missouri and Arkansas. The topography is generally steep, and most stream channels are narrow, although a few larger streams that are remnants of the glacial era are also found. The U.S. Army Corps of Engineers has constructed several reservoirs along the mainstream of the White River for flood control. However, flooding is still a significant problem along many of the major tributaries of the White. Some water supply problems occur during periods of low streamflow. Water use conflicts exist as a result of the desire to preserve scenic areas and yet control flooding.

Water quality is the poorest found in all 10 subbasins: 50 percent of all streams do not meet water quality standards. Ground-water and surface-water quality have been degraded primarily as a result of agricultural runoff and inadequate septic tanks. The incremental fertilizer burden from a biomass enterprise is the highest found in all 10 subbasins (66 pounds per acre). Formation of a blomass enterprise could cause already poor water quality to decline significantly.

No charge 1s imposed for the use of water for agricultural purposes. Neither Arkansas nor Missouri has any legislation that regulates groundwater withdrawal. Riparian rights are in effect for properties that contain or border on a surface water source.

No compacts exist between Arkansas and Missouri regarding the White River. Missouri has no interstate compacts. Arkansas has two state compacts governing the Arkansas River and the Red River. The Arkansas River Compact affects Subbasin 1101, but the Red River Compact does not.

Porjected water requirements for energy generation are the lowest for all 10 subbasins." The requirement for the year 2000 is expected to be only 21 million gallons per day, less than 1 percent of available water supply. ${ }^{4}$ 


\section{Economic Factors}

Total earnings for Subbasin 1101 in 1975 were $\$ 803$ million. Manufacturing generated 22 percent ( $\$ 179$ million) of total earnings, and agricultural earnings were 11 percent ( $\$ 86$ million). Total earnings for 1975 to 2000 are projected to increase by. 150 percent in constant dollars. Manufacturing earnings are estimated to increase 173 percent, but agricultural earnings are projected to increase by only 5 percent over the same period. 5

Total employment for Subbasin 1101 in 1975 was approximately 116,000. Agricultural employment accounted for 20 percent of the subbasin's total employment. Hired farm labor constituted 44 percent of total agricultural labor, owner-operators 56 percent. Ihis is the only subbasin in which owner-operators constitute a majority of the agricultural labor force.

\section{Energy Supp1y and Demand}

Electric energy demand is projected to increase from 2,300 $\mathrm{gWh}$ in 1985 to $46,000 \mathrm{gWh}$ by 2000 , an increase of 1,900 percent. This increase is significantly higher than that in any of the other subbasins surveyed. Hydroelectric power is projected to provide all electric power in 1985. However, the mix of feedstocks in Subbasin 1101 is expected to change dramatically by the year 2000, when nuclear power is projected to supply 75 percent of the subbasin's electric power, and fossil fuels to supply 20 percent. Hydropower will generate the rest. ${ }^{5}$

No major utility system is currently generating electric power in Subbasin 1101. All electric power is purchased from utilities located outside the subbasin and is distributed by municipal systems and rural electric cooperatives. Given the tremendous increase projected for electric energy demand, serious attention should be focused on the establishment'of a biomass enterprise in this subbasin.

\section{Summary}

'I'he need for alternative energy sources in Subbasin 1101 is clear. Electric energy demand is expected to increase approximately 1,900 percent over the period from 1985 to 2000. No electric power is now generated in this subbasin.

Despite the tremendous need for new sources of electricity, the prospects for the establishment of a biomass enterprise in this subbasin are not particularly favorable. The vast majority of farmland is held in small family farms, and only 3 percent of all farms excecd 1,000 acrea. Compliance with the 1977 ERDA guidelines would be difficult. A large quantity of federally controlled forestland is present, but the availability of this land is uncertain. 
Although a large percentage of the labor force is employed in the agricultural sector, the agricultural economy generates a minor portion of the subbasin's total earnings. Furthermore, agricultural earnings are expected to increase significantly less than either manufacturing sector. earnings or the general economy.

Water quality is poor, and some supply problems exist during periods of low streamflow. In addition, the projected incremental fertilizer burden is the highest for all subbasins surveyed, a serious problem in an area whose water quality is already poor.

\section{Subbasin 1702--Northeast Oregon and Eastern Washington}

Subbasin 1702 (Upper/Middle Columbia) incorporates Northeast Oregon and Eastern Washington. This subbasin, which is the largest subbasin surveyed, has a land surface of 57,200 square miles ( 36.6 million acres). Forestland predominates, accounting for 43 percent ( 15.7 million acres) of the land area. Cropland occupies 28 percent (10.2 million acres), and 22 percent ( 8 million acres) is rangeland.

\section{Agricultura1. Factors}

Agriculture is generally restricted to the eastern and southern portions of the subbasin by the topography, which consists of flat-topped plateaus or broad river valleys. The western portion of the subbasin is mountainous, and agriculture is restricted to the narrow river valleys. This western portion is sparsely populated, and its water supply for agricultural use is $11 \mathrm{mited}$.

The two predominant soil types in this subbasin are Lithosol and Chestnut. In Lithosol soils, the A horizon rests directly on hard rock. The rate of rock disintegration barely keeps pace with removal of material by erosion. If the A horizon is 1-2 feet thick, the land can be profitably used for pasture. Many deep, productive soils were once Lithosols, which may be a transitory stage in the development of well-differentiated profiles.

Chestnut soils are distinguished by an accumulation of calcium salts near the surface, and salts of sodium and potassium are present in increasing quantities. The very hark color of the surface soil horizon gives way to a thin, brown layer.

Annual precipitation in the subbasin ranges from 20 to 100 inches. As distinct from all other subbasins, approximately 35 percent of all harvested acres in this subbasin are being irrigated. The frost-free perlod averages 120 to 180 days per year. The predominant field crops are spring wheat, sorghum crops for grain and forage, and corn. Stock grazing is important, because extensive herds of cattle feed on the nutrtitious natural grasses. 


\section{Land Factors}

The distribution of land resources in this subbasin differs from that in the other nine subbasins. The average size farm in 1974 was 1,894 acres. Of the 12,156 farms in this subbasin in 1974, approximately 31 percent $(3,753)$ exceeded 1,000 acres. ${ }^{8}$ These farms, however, are not. composed entirely of good cropland. The high percentages of rangeland and forestland in the subbasin suggest that a balanced distribution of all these land use types exists on individual farms. Farmland costs rose from $\$ 166$ to $\$ 216$ per acre from 1974 to 1978 , an increase of 30 percent. This is smaller than the 10 subbasin average of 46 percent.

Subbasin 1702 has about 22.4 million acres of federally controlled. 1and. The majority of this land ( 57 pcrcent) is concentrated in the Willamette National Forest of Oregon and the Wenatchee National Forest of Washington. The other 43 percent consists of public lands in the state of Oregon controlled by the Bureau of Land Management.

\section{Water Factors}

The mainstem of the Columbia River is the primary water resource in this subbasin. The northern portion of the river from the mouth of the Snake River to the Canadian border contains a series of seven dams and reservoirs, leaving only 57 miles of open river below Priest Falls Dam. These dams were originally constructed to provide hydroelectric power for the Bonneville Power Administration and flood control for the communities downstream. However, diversion facilities have since been constructed by the Bureau of Reclamation to provide water for irrigation. The largest of these is the Columbia Basin Project, which provides water tor more than 1 inflilon acres in che viclully of Muses hake aind Giand Coulee Dam. The Yakima River Valley, is another mafor agricultural area with more than 500,000 acres of irrigated land.

Conflicts exist between competing instream and offstream uses during perlods of low streamflow (summer munchis). The existling dams have already destroyed much of the spawning ground for the anadromous salmon, and operation of reservolrs for irrigation contlicts with the need for release of water to maintain the high water quality required for salmon downstream. This sltuation w11l be exacerbated when the power system in the Northwest shlfes to a thermal base and these dams are operated for peak-1oad power only. In addition, although scattered water shortages already exist, additional reservolrs can only be constructed in areas of prime wildlife habitat or of high scentc value. Therefore, much conflict can be expected to surround any new reservolr proposal.

Water quality has been identified as a major problem during periods of low streamflow, particularly in the agricultural areas. Approximately 40 percent of all streams in the subbasin do not meet water quality standards. Inadequate septlc tanks in some areas have also led to coliform 
problems in the surface and ground water. Sedimentation and erosion problems related to agriculture and lumber production have also been identified.

The incremental fertilizer burden from biomass production is the lowest for all 10 subbasins ( 2.5 pounds per acre). Consequently, a biomass enterprise is not expected to cause a deterioration in water quality.

The state of Oregon does not charge for the use of water for agricultural purposes. In the State of Washington, water permits are required for both ground-water withdrawal and surface-water diversion. For groundwater withdrawal, a permit is required if demand exceeds 5,000 gallons per day. A nominal fee is assessed, and approximately 180 days will elapse from date of application to date of issue. A permit is required for surface-water diversion if an individual plans to irrigate more than 0.5 acres. The permit is usually granted 90 to 120 days after application.

Water requirements for electric power generation are projected to increase from 74 million gallons per day in 1985 to 521 million gallons per day in 2000,4 but the larger amount will be only 1 percent of available supply. This subbasin is a signatory to the Snake River Compact.

\section{Economic Factors}

Total earnings for Subbasin 1702 in 1975 were $\$ 2.9$ billion. Manufacturing earnings were 16 percent ( $\$ 478$ million) of total earnings, and agricultural earnings were 19 percent ( $\$ 448$ million). Total earnings for 1975 to 2000 are projected to increase 103 percent. Manufacturing earnings are estimated to increase by 81 percent, and agricultural earnings are projected to increase by 12 percent over the same period.

Total employment for Subbasin 1702 in 1975 was 260,000. Agricultural employment accounled for 90 percent of total employment. Hired farm labor constituted 91 percent of total agricultural labor, and owner-operators constituted the balance.

\section{Energy Supply and Demand}

Electric energy demand is profected to increase from $120,000 \mathrm{gWh}$ in 1985 to $210,000 \mathrm{gWh}$ in 2000, an increase of 81 percent. Hydropower's share is projected to decline from 79 percent of electric power generation in 1985 to 46 percent by 2000. Conversely, nuclear power as an energy feedstock w111 increase from 21 percent of electric power generatIon in 1985 to 52 percent by 2000.5

No major utility system generates electric power in this subbasin. The two smalil, utflitles that operate there had a generating capacity of 
$61 \mathrm{gWh}$ in 1975.6 The majority of electric power is purchased from utilities outside the subbasin and distributed through municipal systems and rural electrical cooperatives.

\section{$\underline{\text { Summary }}$}

The prospects for the development of a biomass enterprise in Subbasin 1702 are quite favorable. Agricultural earnings in 1974 were 20 percent of the subbasin's total, and 90 percent of total employment was in the agricultural sector. Average farm size in 1974 was 1,894 acres, and about 31 percent of all farms exceeded 1,000 acres. Comp1iance with the 1977 ERDA guidelines would be facilitated by this distriburion of land resnurces. Tn add1.tinn, the subbasin has appruximately $22: 4$ million' acres of federally controlled land. If any of this land becomes available, it could offer a feasible location for an energy farm.

Although sufficient amounts of water are available, water quality has been identified as a major problem during periods of low streamflow. Approximately 42 percent of all streams do not meet water quality standards. However, the low incremental fertilizer burden for biomass production would not cause further deterioration in water quality in the subbasin.

Electric energy demand is projected to increase 81 percent from 1985 to 2000. Because of the favorable characterlstics of this subbasin and the local demand for several types of fuel, a biomass enterprise may nevertheless be a feasible alternative source of energy in the subbasin. 


\section{REFERENCES}

1. Maine State Planning Office, Agriculture in Maine--A Policy Report (March 1979).

2. Paper Industry Information office, untitled publication, Augusta, Maine (March 1978).

3. Energy Research and Development Administration, Division of Solar - Energy, "Solar Program Assessment: Environmental Factors," ERDA 77-47/7 (March 1977).

4. U.S. Water Resources Council, "Water for Energy," Supplemental Reports to the Second National Water Assessment (November 1978).

5. The Nation's Water Resources: Statistical Appendix, Volume 4-1 (April 1978).

6. Electrical World--Directory of Electric Utilities, 84 th edition, McGraw-Hill Inc. (1975).

7. W. J. McCaw III and E. L. Campbell, Conserving the Potomac's. Soil and Water Resources, Interstate Commission on the Potomac River Basin (September 1977).

8. U.S. Department of Commerce, 1974 Census of Agricultural Reports (1977).

9. Walden and Kirklan Realtors, Inc., "Georgia Plantation Map," Albany, Georgia (undated). 
THIS PAGE

WAS INTENTIONALLY

LEFT BLANK 


\section{RANKING OF THE TEN SELECTED SUBBASINS}

Methodology

We have selected criteria for ranking the 10 river subbasins to meet two objectives: (a) indicate in which basins favorable conditions exist for biomass farming; and (b) provide indicators that can be quantified relatively simply and can also be applied to other river subbasins in future studies. The criteria were developed for four impact areas: economic, environmental, socioeconomic, and legal/institutional. A series of indicators were selected in each of these impact areas to comprise the criteria. Many alternative indicators could have been chosen. Those chosen were selected because (1) they could be easily quantified; (2) they were readily available; (3) they supplemented our earlier selection. procedure (see Section V); and (4) they are important factors in biomass energy farm operating success. In some cases the categorization of an indicator is arbitrary as the distinction between what is economic or environmental or socioeconomic or legal is not always clear, and many of the indicators have aspects that are both legal and social or economic and environmental, and so on. Because the indicators are frequently ratios rather than physical quantities, they are expressed on an arbitrary scale. The scale chosen for all the indicators is 0 to 100 . The convention chosen for consistency is that high indicator values correspond to a greater desirability for biomass farming and low values correspond to a smaller desirability.

Each river subbasin is cvaluated for each indicator. A value is assigned to represent how the conditions subsumed under a particular indicator in the river subbasin compare with those in other river subbasins. For example, one indicator would be potential energy yield from bivillass farms in the subbasin; a high yicld is concidcred favorabla. If evaluation of Subbasin 1 shows that its energy yield is 10 times higher than that of Subbasin 2, Subbasin 1 will be assigned a higher value than Subbasin 2 .

After the values are assigned, the indicators are multiplied by pe: centage weights that reflect how much each contributes to the favorability of condtiuns in the impact area under conoidcration. For example, if energy yield (indicator 1 ) is considered to decermine 50 percent of the value of the five cconomio indicators, the assions value fur that: indicator for each subbasin would be multiplied by 0.50 . The weighted values of all the indicators are then summed to obtain an overall value for each impact area. A final similar weighting system is then applied to each impact area's values to obtain a score for the river subbasin. The river subbasin with the highest score will be the most desirable for biomass farming, and the subbasin with the lowest score will be the least desirable. A flow chart of this scoring procedure is shown in Figure VII-1. 


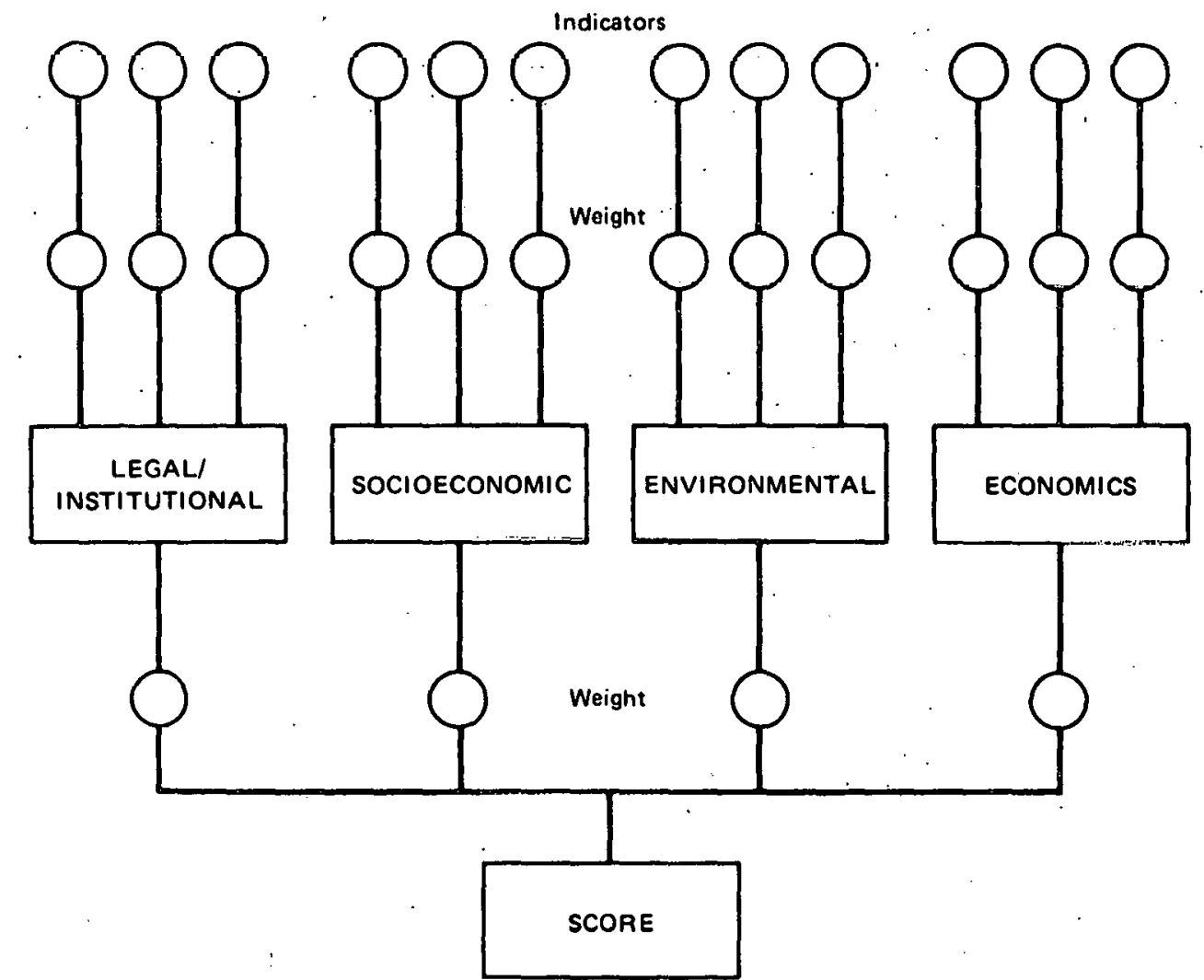

STEP 1

Assign Value

For Indicators

STEP 2

Weight Indicators

STEP 3

Sum Indicators For Each Impact Area

STEP 4

Weight Sums For Each Area

STEP 6

Score River Basin

- The process is repeated for each subbesin under evaluation. Scores are then arranged in descending numerical order to determine the rankings for the subbasins.

FIGURE VII- $i$ PROCESS FOR SCORING EACH RIVEK SUBBASIN" 
An examination of this methodology shows that considerable judgment must be used in assigning weights to the indicators and impact areas. Such judgments rely heavily on the experience of the project team. Comprehensive prediction of absolute levels of desirability is beyond the scope of this study.

\section{Selection of Indicators}

The initial phase of the work for this study involved examining land and water resources in each river subbasin in the contiguous United States to select those with favorable conditions for biomass farming. Ten river subbasins were selected. The next step in our analysis was to rank the 10 selected river subbasins. For this step, we developed a set of criteria to rank subbasins in a systematic. way.

Our earlier analysis revealed that two types of biomass enterprise will be able to compete economically with conventional food and fiber crops in the year 2000. The first type is a combination food(fiber)/ fuel operation for small grains such as wheat, oats, barley, rye, and rice. The second is a fuel-only energy farm that could engage in either silviculture (based on fast-growing, short-rotation hardwoods) or cultivation of kenaf or sweet sorghum. Our ranking of subbasins is based on the assumption that either or both of these types of enterprises could be established in each subbasin.

Each of the four impact areas, and the indicators used to assess them are discussed separately in the following paragraphs. The indicators selected in each impact area are listed in Table VII-1.

\section{$\underline{\text { Economics }}$}

Consideration of economic issues is essential to an evaluation of the desirability of biomass farming in a particular subbasin. Many studies have attcmpted to determine the economir attractiveness of biomass farming. A detailed analysis of this issue therefore did not seem justified and was in any case beyond the scope of this study. Instead, we have selected five indicators to represent various aspects of economic conditions in each river subbasin.

Potential Energy Value of New Energy Farms. This indicator is calculated by

$$
E_{T}=\sum_{i} E b i \sum P b i j \times A i j
$$

where

\footnotetext{
$E_{T}=$ the total potential energy value in the year 2000 of new cncrgy farms in Btu per subbasin per year,
} 
Table VII-I

INDICATORS SELECTED IN EACH IMPACT AREA

Impact Area

Economics

Environmental

Socioeconomic

Legal/Institutional
Indicator

1. Potential Energy Value-New Energy Farms

2. Cost of Agricultural Land

3. Irrigation of Harvested Cropland

4. Change in Energy Demand

5. Added Yield due to Seasonality of Biomass Crops

6. Stream Density

7. Incremental Fertilizer Burden

8. Ground Water Use

9. Nonpoint Source Pollution (Sheet Erosion)

10. Incremental Labor Requirement

11. Local Economies Ágricultural Based

12. S1ze of Farms

13. Water Quality Compacts

14. Water Quality Standards

15. Permits

16. Sole-Source Ayulfers
Unit of

Measurement

Btu

Dullars per acre

Porcent

Gigawatt-hours

Btu

Miles per square milc

Pounds per acre

Percent

Tons per acre per year

Number of workers

Percent

Percent

Number

Percent

Days

Percent 


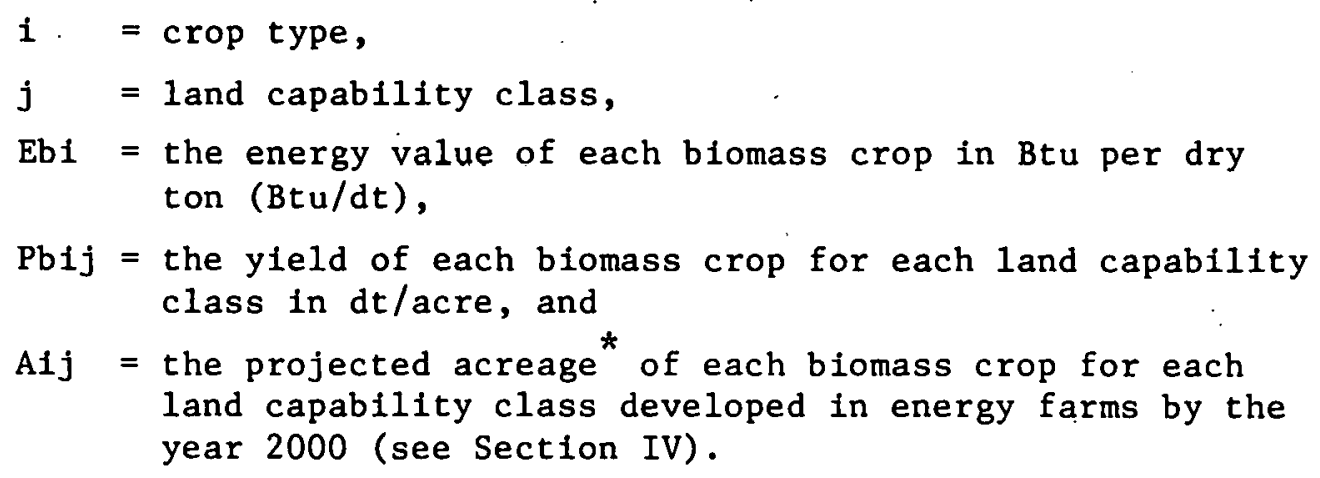

This indicator describes how much energy can be obtained in each subbasin as a result of the successful competition of biomass crops in the marketplace. In other words, it provides a gross indication of the resource potentially avallable for exploitation. The subbasin with the largest total energy value is ranked highest and the other subbasins are ranked relative to that one.

Cost of Agricultural Land. The average cost of agricultural land in each subbasin is calculated by

$$
C=\frac{\Sigma S 1 C 1}{\Sigma S 1}
$$

where

$$
\begin{aligned}
\mathrm{C}= & \text { the average weighted cost of agricultural land in the } \\
& \text { subbasin, } \\
\mathrm{S} I= & \text { the average size farm in county } 1 \text { in acres, and } \\
\mathrm{CI}= & \text { the average cost of agricultural land in county } i \text { in } \\
& \text { dollars per acre. }
\end{aligned}
$$

This information is available from the 1974 Census of Agriculture. ${ }^{1}$

Cost of agricultural and forest land varies considerably between and within river subbasins. The cost of purchasing land can have a significant effect on the economics of producing blomass in a certain location. Agricultural land is used here as a measure of price for both agricultural and forest land. Price information for forest land varied substantially from state to state, and no state had historical records by county in an easily usable format. Consequently, agricultural census data were substituted. We weighted the average cost per county by the average farm size to give adequate emphasis to the variability of agricultural development among counties. The subbasin with the lowest average cost is ranked highest.

Irrigation of Harvested Cropland. The percentage of harvested cropland that is 1rrigated is determined by the following calculation:

\footnotetext{
*Projections are based on rate of return to the farmer.
} 


$$
P=\frac{\Sigma I 1}{\Sigma H i} \times 100
$$

where

$$
\begin{aligned}
& \mathrm{P}=\text { the percentage of harvested cropland that is irrigated, } \\
& \mathrm{II}=\text { the amount of } 1 \text { rrigated land by county in acres, and } \\
& \mathrm{HI}=\text { the amount of harvested land by county in acres. }
\end{aligned}
$$

These data for 1975 were obtained from the WRC Second National Water Assessment. ${ }^{2}$

Irrigation was considered an economic fartor because it is a major cost of farm operation in some areas. Irrigation of a biomass crop could raise the overall cost of production enough to reduce the competitiveness of biomass in the energy marketplace. Therefore, biomass production is less favored in river basins in which a substantial proportion of the cropland must be irrigated. Climate, soil type, and current crop prices play important roles in the farmer's decision to irrigate. Farms in most eastern states use irrigation in very dry years when precipitation is lacking during the crop's critical growth period, or on sandy soils that have poor water-holding capacity. In western states, however, irrigation is a way of life for many crops because rainfall is insufficient throughout the year.

We chuse to use the most recent data for analysis of this indicator. Historical data by county for all basins were only available from the pertodic Census of Agriculture, which was most recently published in 1977. We used the 1978 WRC Second National. Water Assegsment, ${ }^{2}$ which gave 1975 estimates based on projections from the 1974 Census of Agriculture. " A1though projections for 1985 and 2000 were available from the WRC, we elected to use recent historical data to eliminate possible problems related to differing techniques of projection.

Change in Energy Demand. This indicator is defined as the change in electrical energy demand from 1985 to 2000. It is calculated as follows:

$$
\Delta \mathrm{D}=\frac{\mathrm{D}_{2}-\mathrm{D}_{1}}{\mathrm{D}_{1}}
$$

where

$$
\begin{aligned}
& \Delta D=\text { the estimated change in energy demand in the basin, } \\
& D_{2}=\text { the estimated energy demand in gigawatt-hours in } 2000 \text {, and } \\
& D_{1}=\text { the estimated energy demand in gigawatt-hours in } 1985 .^{2}
\end{aligned}
$$

Although it is not strictly an economic factor, new electric power demand is a very important indicator of the future need for fuels of all types and for the feedstocks produced from new energy farms. 
Subbasins that experience a large percentage increase in energy demand from 1985 to 2000 will need to expand their electrical generation capacity proportionally. Therefore, alternative sources of energy (perhaps for a supplemental supply) would be favored in these subbasins. The technology to convert biomass will be more mature by 1985 , and in all probability will be considered (on the basis of economics) an even more attractive alternative to conventional energy sources. Consequently, we selected the time period of 1985 to 2000 for this analysis. A basin with a large $\Delta \mathrm{D}$ is ranked high.

Seasonality of Biomass Crops. This indicator is calculated as follows :

$$
\Delta E=\frac{\left(E_{T}-E_{S}\right)(H-1)}{E_{T}}
$$

where

$$
\begin{aligned}
\Delta \mathrm{E}= & \text { a factor representing the incremental energy yield of the } \\
& \text { subbasin based on the potential number of harvests per } \\
& \text { year, }
\end{aligned}
$$

Originally, we evaluated the competitiveness of biomass crops against existing food and fiber crops in the subbasin by assuming one harvest per year. In reality, farmers in the Southeast and Southwest are able to harvest two or three crops per year and to reduce their fixed operating costs per unit of production as a result. This indicator is included because subbasins with a longer growing season have an inherent economic and environmental advantage. Because we assumed that silviculture crops are available throughout the year, the energy value associated with those crops is subtracted from the energy value of the whole subbasin. Subbasins with a large $\Delta E$ are ranked high.

\section{Environmental}

Extensive development of biomass crops as an alternative energy source must be realistically balanced against potential environmental limitations and constraints. Although absolute impacts cannot be addressed in a planning study of this nature, we can assess relative impacts by selecting indicators that represent a variety of potentially important ones. Four indicators have, been selected. 
Stream Density. Stream density or drainage density is defined simply as the stream length per unit area;

$$
\mathrm{DD}=\frac{\sum \mathrm{L}}{\mathrm{A}_{\mathrm{b}}}
$$

where

$$
\begin{aligned}
& D D= \\
\Sigma L= & \text { the cumulative length of all streams in the subbasin in } \\
& \text { miles, and } \\
A_{b}= & \text { the area of the subbasin in square miles. }
\end{aligned}
$$

Traditionally, the concept of drainage density has been applied as an indication of the drainage network in each subbasin and as a basis for compartson among several subbasins. ${ }^{4}$ Our purpose here is somewhat different. We are using drainage density as a measure of the vulnerability of a river basin to surface water pollution. If streams intersect the land surface frequently, runoff from agricultural lands has more chance of entering a stream, thereby reducing water quality. In other words, a higher stream density increases the probability that surface water degradation will occur.

Degradation of surface water from agricultural runoff has been identified as a major problem in the United States. ${ }^{5}$ Basin water quality plans being developed under Section 208 of P.L. 92-500 have been assigned the task of addressing this problem. Few of these studies have been completed and many are only at an incipient stage. Therefore, quanitative data were generally unavaliable for this study, and it was neceecary to select a representative indicator. Subbasins with a small DD are ranked high.

Incremental Fertilizer Burden. The incremental fertilizer burden for each subbasin is calculated as follows:

$$
I B=\frac{R \times \sum B}{\sum H i}
$$

where

$I B=$ the incremental hurden of phosphorouc and nitrogen,

$\mathbf{R}=$ the average rate of application of phosphorous and nitrogen in pounds per acre, ${ }^{6}$

$\Sigma B=$ the projected acreage of biomass crops in the year 2000 developed on currently unused land, and

$\Sigma \mathrm{Hi}=$ the total harvested acreage aggregated by county in the subbasin. A subbasin with a high IB is ranked low. 
Although primary ingredients used in commercial fertilizers are nitrogen, phosphorous, and potassium, either in elemental or oxide forms, we condidered only phosphorous and nitrogen in this analysis. Phosphorous pollutes water by stimulating growth of algae and other aquatic plants in bodies of water. If excessive phosphorous is present, the increased growth will lead to depletion of oxygen in the bottom water, decreased water clarity, and degradation of aquatic habitats. Nitrogen in the presence of phosphorous can also affect plant growth, and it can affect water quality in other ways as well. Three forms of nitrogen that have significant impacts on water quality are ammonia, nitrite, and nitrate. Ammonia is toxic to aquatic animals under certain water temperature and acidity conditions. Nitrite can cause an illness called methemoglobinemia in which oxygen transfer of the blood is impatred. Although the level of nitrite that can cause 1llness is almost never reached in water, nitrate can be converted into nitrite in infants' bodies. If nitrate exceeds 10 parts per million ( $\mathrm{ppm}$ ) in an infant's water, methemoglobinemia may result. This concentration is extremely rare in surface water, but it can be reached in ground water frequently enough to be considered a water quality problem.

Ground Water Use. This indicator is defined as the percent of domestic water that is supplied by ground water, and is calculated as follows :

$$
\mathrm{Pg}=\frac{\mathrm{G}}{\mathrm{W}}
$$

where

$$
\begin{aligned}
\mathrm{Pg}= & \text { the percent of domestic water that is supplied by ground } \\
& \text { water, } \\
\mathrm{G}= & \text { the volume of ground water used as domestic supply in } \\
& \text { million gallons per day, and } \\
W= & \text { the volume of all wales used as domcatic oupply in million } \\
& \text { gallons per day. }
\end{aligned}
$$

These data are available for major water resource regions for 1975 from the U.S. Geological Survey. ${ }^{7}$

Significant problems of ground water contamination have resulted in some subbasins from the application of hazardous chemicals to agricultural 1and. The first place these problems usually appear is in drinking water obtained from wells. Contamination of aquifers is vcry difficult and expensive to clean up. Regulations promulgated under the Safe Drinking Water Act (P.L. 93-523) have made the first steps toward preventing such contamination. However, distributive, or nonpoint, sources of pollution such as those occurring from agricultural land are extremely difficult to control. Therefore, development is favored for subbasins in which ground water does not represent a significant portion of the domestic water supply, and subbasins with a large $\mathrm{Pg}$ are ranked low. 
Nonpoint Source Pollution (Sheet Erosion). This indicator is defined as the average sheet erosion from cropland in the subbasin in tons per acre per year. This value was determined for the WRC Second National Water Assessment ${ }^{2}$ on the basis of average cropland erosion rates estimated by Iowa State University. These estimates are for sheet and rill erosion of the land surface caused by rainfall. Gully and streambank erosion, wind erosion, and gravity-caused movement of the soil mantle are not included. Nonpoint source pollution results from contaminants that are generated and transported over a wide area, such as agricultural or urban runoff. Addition of sediment to a water body through the process of sheet erosion has been identified as the major single pollutant contributing to nonpoint source pollution. Raindrops hit the ground and dislodge soil particles, moving them downslope in the thin layer of water flowing over the land surface. This sediment becomes a problem when it enters a hody of wacer. Suspended solids can muddy drinking water, clog intake pipes, degrade fish habitat, and increase the process of lake eutrophication.

Very little information exists on nonpoint sources of pollution. EPA is authorized to study nonpoint sources through the area-wide quality planning studies mandated by Section 208 of the Federal Water Pollution Control Act, 1972 Amendments (P.L. 92-500). However, studies on this problem are only now beginning in some states and in others are still far from completion. The WRC made some crude estimates of point versus nonpoint sources in the nation's waterways ${ }^{2}$ based on two parameters: Biological Oxygen Demand (BOD) and Total Suspended Solids.(TSS). They found that BOD discharges currently result from point sources except in the Missouri and the Upper and Lower Mississippi River Basins, in which nonpoint sources of BOD predominate. The reverse is true for TSS. In a large portion of the nation, nonpoint sources are responsible for more than 90 percent of the 'ISS in waterways.

Our selection of sheet erosion as an indicator for potential nonpoint source problems is realistic. It provides a way of ranking basins by their potential for nonpoint source pollution from erosion of agricultural land. Basins with a high erosion rate are ranked low.

\section{Socioeconomic}

Socioeconomic factors are those that have an economic or social impact on the individuals or the communities in the region. The impacts can be eitles pusltive or negative, depending on existing conditions and the kinds of change expected. A biomass farm is essentially the same as a very large farm, and therefore any socineconomic impacts from biomass development will be related to the establishment of such an agricultural project in the region. We have selected two indicators as a measure of socioeconomic impacts.

Incremental Labor Force. The incremental labor force is calculated as follows: 


$$
\mathrm{IL}=\frac{\sum \mathrm{Fi} \times \sum \mathrm{B}}{\sum \mathrm{Hi}}
$$

where.

$$
\begin{aligned}
\text { IL }= & \text { the incremental labor force needed for new energy form } \\
& \text { crops (year } 2000), \\
\Sigma F I= & \text { the number of hired farmworkers within the subbasin } \\
& \text { aggregated by county, } \\
\Sigma B= & \text { the projected acreage of biomass crops in the year } \\
& 2000 \text { developed on formerly unused land, and } \\
\Sigma H i= & \text { the total harvested acreage aggregated by county. }
\end{aligned}
$$

The data necessary to make this analysis are available from the 1974 Census of Agriculture ${ }^{1}$ and the SRI site surveys and analysis.

A typical biomass farm may require 200 to 300 seasonal agricultural workers during planting and harvesting. If such workers are not available, they must be imported from another area of the country. This may cause unfavorable community reaction and problems in providing adequate housing, schooling, and other local services. However, bringing substantial new acreage into production may dramatically improve the economic conditions in a region by stabilizing fluctuations and providing long-term employment for agricultural workers. Therefore, although localized problems may result, regional economic improvement should occur over time as a result of biomass production. Our indicator provides an estimate of the additional farm employment generated in the year 2000 for biomass crops produced on formerly unused land. A basin with a high IL is ranked high.

Local Economy. This indicator is defined as the percentage of the local economy that is based on agriculture:

$$
\mathrm{Ea}=\frac{\sum \mathrm{A}}{\sum_{\mathrm{E}}} \times 100
$$

where

$$
\begin{aligned}
E a= & \text { the percentage of the local economy in the subbasin that } \\
& \text { is based on agriculture, } \\
\Sigma A= & \text { the total earnings of agriculture including forestry and } \\
& \text { fisheries aggregated by county, and. } \\
\Sigma E= & \text { the total earnings of all sectors aggregated by county } \\
& \text { for the subbasin. }
\end{aligned}
$$

These parameters have been determined from census data for each subbasin by the WRC. ${ }^{2}$ A subbasin with a large Ea is ranked high.

Agriculture is well-integrated into a region when it is linked to a large infrastructure that provides fertilizer, farm machinery, agricultural 
labor, commodity storage and transport, and market distribution. In. addition, many federal, state, and county agencies are available to offer consultation on every aspect of agriculture. The development of biomass farms is favored in river subbasins that have a strong agricultural foundation.

Earnings were selected as our measure for several reasons. Most important, the information is readily available by county from the Census Bureau. Second, individual earnings describe the economic activity in the subbasin. They are an indication of how much of the local economy is dependent on the agricultural sector. If agricultural earnings are proportionally large, this impliee that a sccond tier of merchandisers exists to provide service to that sector. It furthermore implips that the wollbeing of the agricultural sector is important to the region as a whole, and that it will therefure be encouraged to remain strong.

\section{Legal and Institutional}

Legal and institutional issues are often overlooked in the analysis of possible certain actions because of the difficulty in quantifying their impacts. However, they are often the primary reason for the success or fallure of a proposed project. Although legal and institutional issues can be of many types, we have selected five indicators that provide a measure of the desirability of biomass farming in a particular river subbasin. We have attempted to be as quantitative as possible in this analysis, even though this approach refutres that many potcntially valuable indicators be eliminated because they cannot be quantified.

Size of Farms. This indicator is calculated by

$$
S=\frac{\sum F 1}{\sum \mathrm{Fa}} \times 100
$$

where

$S$ = the percentage of the harvested acreagc in the suhbasin that is attributed to large farms,

$\Sigma F 1=$ the harvested acreage (aggregated by county), of farms that are larger than 1,000 acres, and

$\sum \mathrm{Fa}=$ the harvested acreage (agpregated by county); nf farms that are larger than 50 acres.

These data are available from the 1974 Census of Agriculture. ${ }^{1}$

Considerable time and money will be saved in land acquisition if only a few owners are involved. Therefore, biomass is favored in subbasins in which agricultural land is characteristically held in large parcels, 1,000 acres or more. During site visits, we determined that information on parcel size was not avallable by county for most states. 
No consistent information comparable to that in the 1974 Census of Agriculture $^{1}$ was avallable for forest land. Consequently, we have forgone: an analysis of that portion of the projected development.

Our indicator is based on a percentage of harvested acreage to exclude acreage unavailable for biomass production, such as acreage devoted to farm ponds, feedlots, and buildings. We use Fa instead of total harvested acreage to eliminate very small farms (less than 50 acres) that may be operated primarily as a secondary means of support. A subbasin with a large value for $S$ is ranked high.

Water Quality Compacts. This indicator is calculated by summing the number of interstate and international water quality compacts in each subbasin. This information was obtained from the WRC Second National Water Assessment ${ }^{2}$ and from the environmental protection or water resource agencies in each state. A subbasin with a large number of water quality compacts is ranked low.

Interstate or international compacts that set water quality standards can complicate any large-scale development in a river subbasin. For example, environmental assessments will most likely be required before construction can begin. The burden of proof is on the developer to show that the standards established by the compact will not be exceeded. If public controversy is aroused or if some evidence exists that the standards cannot be met, resolution of interstate quarrels can only be achieved by the U.S. Supreme Court and international quarrels by the International Joint Commission (United States and Canada). In either case, it can take years to reach a final resolution of the controversy. Therefore, river subbasins governed by such compacts are less favorable locations for b1omass farms.

An example of this kind of possible delay is occurring in the Upper Missouri River Basin. The Poplar River Basin is being studied to determine the environmental effects of damming and withdrawal of water for thermalelectrlc canversiui in Saskatchcwan. The International Joint Commission has been evaluating the problem for several years and is working toward development of a combined water quantity/water quality compact for the basin. Once the compact is established, additional development in the basin will be carefully scrutinized to determine whether conditions imposed in the compact will continue to be met.

Standards. This indicator is defined as the percentage of stream miles that do nut meet water quality standards. These estimates are weighted averages determined for the WRC's Second National Water Assessment. ${ }^{2}$ They represent the positions of streams that do not and will not meet quality standards for water uses now designated as beneficial even after application of the best practical technology in industry and secondary wastewater treatment by municipalities. A subbasin with a high. percentage is ranked low. 
Federal regulations require classification of all streams to determine their most beneficlal use, development of water quality plans for achieving the best use of all water bodies, and establishment of permit systems for all point-source discharges into surface water. Individual states are usually operating under regulatory timetables for correcting pollutant problems and achieving water quality goals. If a large percentage of the streams in a subbasin are not expected to meet existing water quality standards, the states involved will review thoroughly all plans for development and may impose severe restrictions on capturing, treating and discharging run-off water. Therefore, biomass development is not favored in those subbasins.

Permits. This indicator is estimated by.

$$
P t=T s+T g
$$

where

$$
\begin{aligned}
\mathrm{Pt}= & \text { the total minimum amount of time required to obtain the } \\
& \text { necessary ground- and surface-water permits in the basin, } \\
\mathrm{Ts}= & \text { the minimum timc required Lu ubtain surface, water permits, } \\
& \text { and } \\
\mathrm{Tg}= & \text { the minimum time required to obtain ground-water permits. }
\end{aligned}
$$

A basin with a large $P t$ is ranked low.

Permits are required for much of the development that will take place on a biomass farm. In this case, we are limiting our analysis to the permits required for the diversion of surface water, the construction of an irrigation diversion system, and the construction of a withdrawal. system for ground water. The total number of permits required and the amount of t1me required to obtain the permits are two critical elements in planning a biomass farm. Certainly, subbasins without permit systems are favored over areas that require permits. Any construction In a waterway requires a permit from the U.S. Army Corps of Engineers. These requirements are the same for every subbasin, and therefore were not included in evaluatiug this indicator.

Each statc was contacled to decermine whether permits were required there. Of the states in which a stuly subbaeln 13 located, unly Minnesota, Maryland, Oregon, and Washington require that a water right be obtained for surface water diversion. A few other states require permits for well construction, ground-water withdrawal, or construction in a navigable waterway. The minimum length of time required to obtain each permit was summed for each state, and the stale with the largest value for $P$ t was used to represent the subbasin for ranking purposes. A subbasin with a low total was ranked high. 
Sole-Source Aquifers. This indicator is calculated as follows:

$$
\mathrm{SS}=\frac{\mathrm{Aa}}{\mathrm{Ab}} \times 100
$$

where

$$
\begin{aligned}
\mathrm{SS}= & \text { the percentage of the subbasin's area that overlies a } \\
& \text { sole-source aquifer, } \\
\mathrm{Aa}= & \text { the area of the aquifer within the subbasin in square } \\
& \text { miles, and } \\
\mathrm{Ab}= & \text { the area of the basin in square miles. }
\end{aligned}
$$

This information was obtained from the office of Drinking Water, U.S. Environmental Protection Agency ${ }^{8}$ and is published in the Federal Register. A basin with a high value for $S S$ is ranked low.

The Safe Drinking Water Act (P.L. 93-523) has established a procedure whereby, under certain specified conditions, an aquifer can be declared sole source. This determination severely restricts any development in the area overlying the aquifer system that may adversely affect ground-water quality. Therefore, subbasins with a high percentage of area overlying a sole-source aquifer are ordinarily ranked low.

Six aquifers have now been declared sole source. One is in the vicinity of one of our study subbasins, the Spokane Aquifer in Spokane County, Washington. However, state and federal officials in this state verified for us that subbasin 1702 does not overlap the Spokane Aquifer. Therefore, none of our selected subbasins contains a sole-source aquifer, and all have equal rankings. The indicator is included nevertheless. because of its potential importance in evaluations of other subbasins.

\section{Limitations of the Methodology}

Any method developed to rank or compare dissimilar items must necessarily use techniques that oversimplify the characteristics of the item studied. This method is no exception. The ability to group or compare favorable characteristics is achieved at the expense of some detail in the analysis. Furthermore, because a weighting system is applied to the overall scores used to rank the subbasins, the conclusions reached will depend to some extent on the values held by the groups applying the method.

We have identified four general limitations of our methodology: (1) the results are most useful for making comparisons; (2) the areas covered are large; (3) the indicators used are merely gross measurements; (4) the results by themselves do not allow evaluation of localized biomass demand.

Our ranking method provides a general comparison of the desirability of developing biomass farms in one river basin"rather than another. 
Therefore, this method is only useful for comparison. One basin cannot be analyzed in isolation to arrive at a "desirability score."

Ne1ther is the methodology useful for a detailed study of a relatively small geographic region. Rather, it allows large geographic areas to be screened and smaller geographic areas within them to be compared. The size of the subbasins we evaluated ranged from 15,000 to 57,000 square miles. Although our indicators were constructed to eliminate differences related to varying sizes, the total basin areas are nevertheless quite large. Substantial detail is lost in evaluating regions of this size.

Partially as a result of the size of the area studied and partially as a result of limitations on the amount of information available, the selected indicators are only gross measures of notential problomn or benefits. During the course of this stury, we found it neccosary to change indicators several times so that comparable information could be obtained for each subbasin.

The study methodology was not designed to provide a detailed regional competitive fuels analysis (a model to perform this kind of analysis was developed for the mission analysis study SRI recently completed for DOE), nor were specific markets for numerous local biomass products identified. Therefore, the methodology does not allow localized biomass demand and markets to be readily identified. Rather, it concentrates on identifying a region's desirability for developing large-scale biomass farms. Evidence for numerous localized markets does exist, however, and during the on-site analysis the SRI study team observed several operating direct combustion and fermentation biomass conversion projects (corn to ethanol in Michigan and wood chips to steam in Maine).

\section{Study Results}

Th1s ranking method gives promise for being a valuable tool in evaluating different geographical regions of the country on the basis of simllar and quantifiable characteristics. Moroover, oensitivity analyses of the results permit a more thorough understanding of the major differ ences between regions and the potential for variability in the results.

For each subbasin, we determined the value for each indicator. Table VII-2 through VII-5 summarize this determination for the cases in which earh indicator ie oqually wrightel. As sluwt, cach subbasin lias an indicator value, an assigned value, and a ranking. The indicator value is measured in the units 1 isted after the indicator name. For example, Potential Energy Value is measured in Btu. However, the assigned value is dimensionless and represents a value from 0 to 100 that indicates how the indirator value for onc basin compares wilh the indicator values for the other nine basins. In other words, the assigned value is a sem1quantitative measure based on one indicator, of the desirability of biomass 
Table VII-2

ECONOMICS IMPACT SUMMARY
POTENTIAL ENEROY VALUE (BTU)

\begin{tabular}{|c|c|c|}
\hline EASIN & $\begin{array}{l}\text { I NDI CATOR } \\
\text {. VALUE }\end{array}$ & $\begin{array}{l}\text { ASSI GNED } \\
\text { VALUE }\end{array}$ \\
\hline $\begin{array}{l}101 \\
206 \\
302 \\
304 \\
306 \\
404 \\
602 \\
701 \\
1101 \\
1702\end{array}$ & $\begin{array}{l}.416 E+13 \\
.415 E+16 \\
.133 E+15 \\
.359 E+15 \\
.204 E+15 \\
.137 E+15 \\
.866 E+15 \\
.792 E+15 \\
.125 E+15 \\
.107 E+16\end{array}$ & $\begin{array}{r}0.00 \\
97.96 \\
15.35 \\
44.54 \\
26.16 \\
16.03 \\
66.06 \\
71.53 \\
14.02 \\
79.97\end{array}$ \\
\hline & & - \\
\hline
\end{tabular}

INCREMENTAL ENEROY DEMAND (OW-HOURS)

$\begin{array}{ccr}\text { BASIN } & \begin{array}{c}\text { INDICATOR } \\ \text { VALUE }\end{array} & \begin{array}{c}\text { ASSIONED } \\ \text { VALUE }\end{array} \\ 101 & .186 E+03 & 70.06 \\ .101 & .186 E+03 & 78.05 \\ 306 & .162 E+03 & 70.40 \\ 304 & .236 E+03 & 68.55 \\ 306 & .198 E+03 & 61.37 \\ 404 & .812 E+02 & 24.26 \\ 602 & .718 E+02 & 18.00 \\ 701 & .423 E+02 & 2.16 \\ 1101 & 191 E+04 & 100.00 \\ 1702 & : 1807 E+02 & 23.93\end{array}$

AVERAGE COST OF AO LAND (\$/ACRE)

$\begin{array}{ccccc}\text { RANKINO } & \text { BASIN } & \begin{array}{c}\text { INDICATOR } \\ \text { VALUE }\end{array} & \begin{array}{c}\text { ASSIONED } \\ \text { VALUE }\end{array} & \text { RANKINO } \\ 10 & 101 & .337 E+03 & 67.20 & 3 \\ 1 & 206 & .758 E+03 & 4.67 & 10 \\ 8 & 302 & .482 E+03 & 31.14 & 8 \\ 5 & 304 & .487 E+03 & 30.09 & 8 \\ 6 & 306 & .460 E+03 & 35.34 & 7 \\ 7 & 404 & .466 E+03 & 36.34 & 6 \\ 4 & 602 & .382 E+03 & 54.57 & 4 \\ 3 & 701 & .435 E+03 & 36.60 & 5 \\ 9 & 1701 & .283 E+03 & 61.47 & 2 \\ 2 & 1702 & .166 E+03 & 100.00 & 1\end{array}$

PORTION OF LAND BEINO IRRIGATEO (PERCENT)

BASIN INDICATOR ASSIONED RANKINO

$\begin{array}{rrrr}101 & .111 E+01 & 63.62 & 5 \\ 206 & .754 E+00 & 71.67 & 5 \\ 302 & .517 E+00 & 78.58 & 5 \\ 304 & .300 E+02 & 5.86 & 3 \\ 306 & .432 E+01 & 33.09 & 7 \\ 404 & .230 E+01 & 47.16 & 6 \\ 602 & .116 E+00 & 98.59 & 1 \\ 701 & .601 E+00 & .79 .08 & 2 \\ 1101 & .459 E+01 & .31 .82 & 8 \\ 1702 & .344 E+02 & 5.08 & 10\end{array}$

- additional yield dUE to SEASONALITY (BTU) BASIN INDICATOR ASSIGNED RANKINO

$\begin{array}{lll}101 & 0 . & 25.64 \\ 206 & 0 . & 25.64 \\ 302 & .600 E+14 & 93.17 \\ 304 & .210 E+15 & 93.99 \\ 306 & 0.157 E+15 & 93.61 \\ 404 & 0 . & 25.64 \\ 602 & 0 . & 25.64 \\ 701 & 0 . & 25.64 \\ 1101 & 0 . & 25.64 \\ 1702 & 0 . & 25.64\end{array}$

Source: SRI estimates based on the results in Appendix E. 
Table VII-3

ENVIZONMENTAL IMPACT SUMMARY

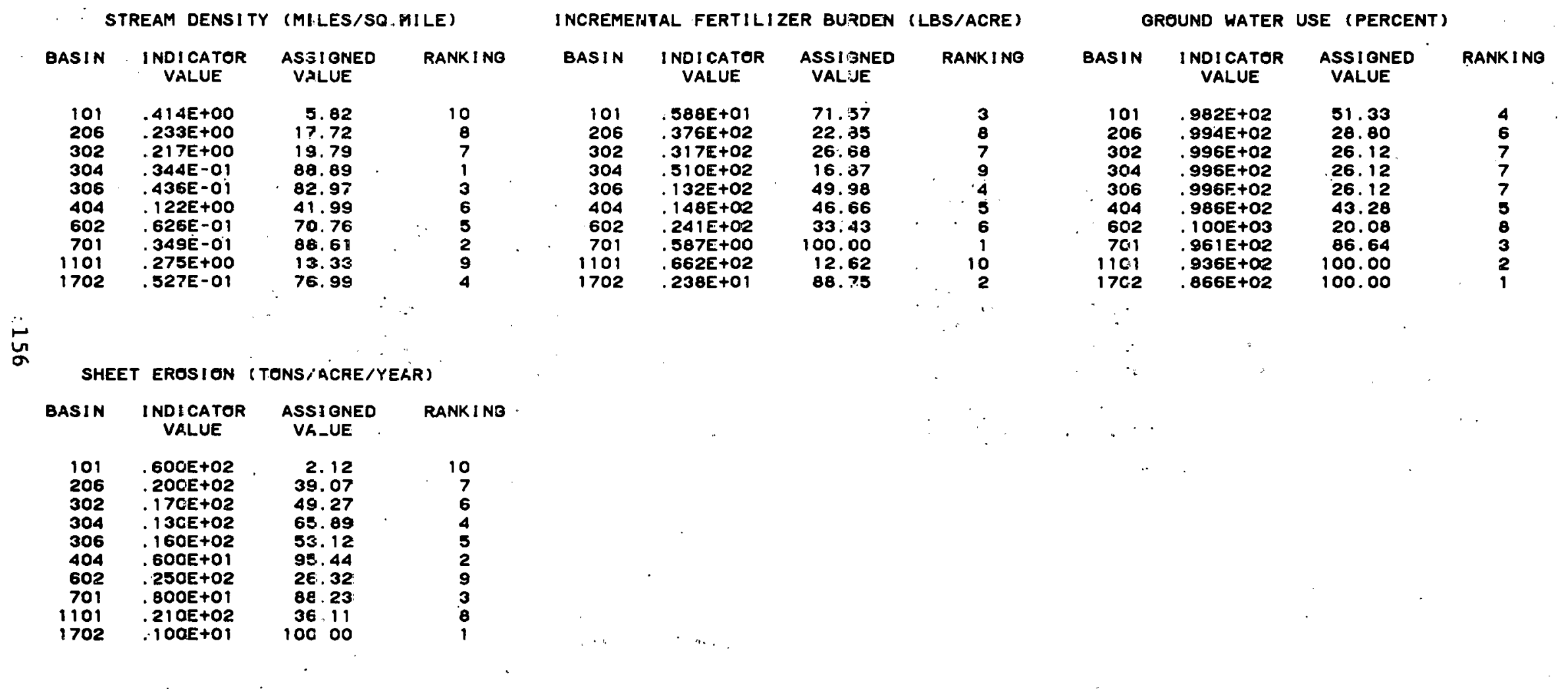

Source: SRI estimates basec on the results in Appendix E. 
Table VII-4

SOCIOECONOMIC IMPACT SUMMARY

INCREMENTAL LABOR. REQUIREMENT (WORKERS)

BASIN INDICATOR ASSIONED VALUE VALUE

RANKINO

.59
63.18
92.57
91.93
52.15
63.12
59.86
13.27
47.13
26.45

10
3
1
2
6
4
5
9
7
8

LOCAL ECONOMY (PERCENT)

$\begin{array}{cc}\text { BASIN } & \begin{array}{c}\text { INDICATOR } \\ \text { VALUE }\end{array} \\ & \\ 101 & .840 E+01 \\ 206 & .120 E+01 \\ 302 & .466 E+01 \\ 304 & .508 E+01 \\ 306 . & .388 E+01 \\ 404 & .421 E+01 \\ 602 & .872 E+01 \\ 701 & .649 E+01 \\ 1101 & .138 E+02 \\ 1702 & .223 E+02\end{array}$

ASSI BNED

VALUE

RANKINO

66.70

0.00

36.24

40.60

27.63

31.32

68.51

53. 52

86.21

95.81

4
10
7
6
9
8
3
5
2
1

Source: SRI estimates based on the results in Appendix E. 
Table VII-5

LEGAL/INST ITUTIONAL IMPACT SUMMARY
FARMS OVER 1000 ACRES (PERCENT)

\begin{tabular}{|c|c|}
\hline BASIN & $\begin{array}{l}\text { I ND I CATOR } \\
\text { VALUE }\end{array}$ \\
\hline $\begin{array}{l}101 \\
206 \\
302 \\
304 \\
306 \\
404 \\
602 \\
701 \\
1101 \\
1702\end{array}$ & $\begin{array}{l}.418 E+01 \\
.323 E+01 \\
.346 E+01 \\
.817 E+01 \\
.868 E+01 \\
.976 E+00 \\
.188 E+01 \\
.176 E+01 \\
.316 E+01 \\
.309 E+02\end{array}$ \\
\hline
\end{tabular}

DAYS REQUIRED TO OBTAIN IRRIGATION WATER

INDICATOR ASSIGNED RANKINO
VALUE

0 .

$\begin{array}{rrrr}101 & 0 . & 88.96 \\ 206 & .180 E+03 & i 8.55 \\ 302 & .300 E+02 & 26.38 \\ 304 & .180 E+03 & 18.55 \\ 306 & .180 E+03 & 18.55 \\ 404 & 0 . & 88.96 \\ .602 & 0 . & 89.96 \\ 701 & .120 E+03 & 20.18 \\ 1101 & 0.1 .0 & 83.96 \\ 1702 & .600 E+02 & 23.17\end{array}$

51.93

40.97
43.84

77.87

79.78

20.86

10.84

90.02

$\$ 8.60$
ASSI INEDD
WATER OUALITY COMPACTS

$\begin{array}{ccc}\text { BASIN } & \begin{array}{c}\text { INDICATOR } \\ \text { VALUE }\end{array} & \begin{array}{c}\text { ASSIONED } \\ \text { VALUE }\end{array} \\ 101 & .100 E+01 & 27.17 \\ 206 & .100 E+01 & 27.17 \\ 302 & 0 . & 93.92 \\ 304 & 0 . & 93.92 \\ 306 & 0 . & 93.92 \\ 404 & .200 E+01 & 22.12 \\ 602 & .100 E+01 & 27.17 \\ 701 & .200 E+01 & 22.12 \\ 1101 & .100 E+01 & 27.17 \\ 1702 & .100 E+01 & 27.17\end{array}$

POLLUTED STREAMS (PERCENT)

RANKINO
2
2
2
1
1
1
3
2
3
2
2

ASSIONED. VALUE

86.73

65.33

22.85

14.88

22.85

86.73

86.73

86. 73

10.15

14.88
RANKINO

SOLE-SOURCE AQUIFERS (PERCENT)

$\begin{array}{rl}\text { BASIN } & \text { INDI } \\ & \\ 101 & 0 . \\ 206 & 0 . \\ 302 & 0 . \\ 304 & 0 . \\ 306 & 0 . \\ 404 & 0 . \\ 602 & 0 . \\ 701 & 0 . \\ 1101 & 0 . \\ 1702 & 0 .\end{array}$

\begin{tabular}{|c|c|}
\hline $\begin{array}{l}\text { DI CATOR } \\
\text { VALUE }\end{array}$ & $\begin{array}{l}\text { ASSI GNED } \\
\text { VALUE }\end{array}$ \\
\hline$\cdot$ & $\begin{array}{l}100.00 \\
100.00 \\
100.00 \\
100.00 \\
100.00 \\
100.00 \\
100.00 \\
100.00 \\
100.00 \\
100.00\end{array}$ \\
\hline
\end{tabular}

RANKINO

1
5
2
5
5
1
1
4
1
3

100.00

Source: SRI estimates based on the results in Appendix E. 
farming in one basin over another. We used a statistical function to assign values that arrayed the raw results and calculated the assigned value on the basis of the overall distribution of the results.

As shown in Table VII-2 through VII-5, a substantial variation in ranking of the basins occurs from one indicator to the next. For example, Basin 1702 (Upper/Middle Columbia) is alternatively ranked second, first, tenth, eighth, and finally third. As might be expected, the selection of indicators plays a major role in the outcome of the results, which is why the selection must be made very carefully. Also note that the range in assigned values varies substantially from one indicator to the next. The assigned values for Incremental Energy Demand range from 2.16 to 100.00, but five of the basins are clustered in the range of 70.40 to 88.55 . On the other hand, assigned values for Potential Energy Value range from 0.00 to 97.96 with little clustering. To take this variation into consideration, assigned values are used in determining the overall ranking of the basins. Similar variations occur for all the impact areas.

Detailed results showing the basis for the calculations on which these summaries are based are given in Appendix E. The worksheets used for obtaining the basic data for evaluating the indicators are provided in Appendix $\mathrm{F}$.

Indicator and Impact Area Weighting

The weights assigned to indicators and impact areas were determined by the study team on the basis of their judgment of the relative importance of each factor. Weighting values range from 0 to 100 percent and can be expected to vary significantly in other studies to reflect. different objectives of different studies. Frequently a Delphi or group judgment process may be used to obtain a consensus agreement on the value of each factor. In other cases, weights may be assigned by the project leader or sponsor on the basis of a judgment of the importance of each factor. In this analysis, several alternative weighting methods were used to reflert the sensitivity of the model, and the rankings varied significantly with different weightings.

\section{Weighted Ranking Results}

Emphasis on Economic, Socioeconomic, and Environmental Impacts

An overall ranking based on one possible weighting procedure is shown in Table VII-6. In this case, economic, environmental, and socioeconomic impacts were most heavily weighted, and legal/insti.tutional impacts were least heavily weighted. Individual weightings for each indicator were assigned in a similar fashion.

The score is derived by multiplying the assigned value for each indicator by the assigned weighting (listed at the bottom of the table). 
Table VII-6

SUMMARY OF RESULTS: IF ECONOMICS, ENVIRONRENTAL, AND SOCIDECONORIC FACTORS ARE EMPHASIZED

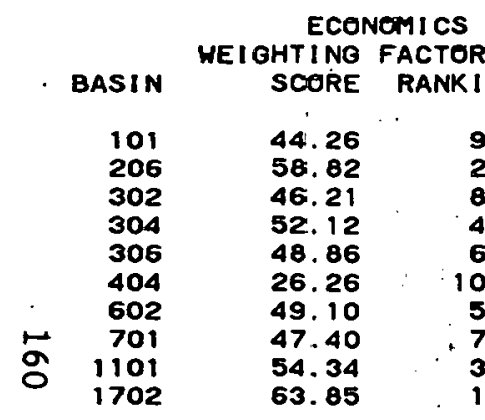

ENVI RONMENTAL WEIGHTING FACTOR $=.20$

SCORE RANKING

35.74
26.22
30.55
48.06
56.63
57.35
39.65
92.87
27.41
89.75

35.74
26.22

26.22

48.06

56.63

39.65

92.67

89.75
SOCI OECONOMIC

WEIOHTING FACTOR $=.30$

SCORE RANKING

$$
\begin{aligned}
& 27.04 \\
& 37.91 \\
& 70.04 \\
& 71.40 \\
& 42.34 \\
& 50.40 \\
& 63.32 \\
& 29.37 \\
& 62.76 \\
& 54.20
\end{aligned}
$$

10
6
2
1
7
6
3
9
4
5
.30

ECONOMICS INDICATOR WEIGHTINO FAETORS ARE ENVIRONMENTAL INDICATOR WEIGHTINA FACTORS ARE NTITUTIONAL INDICATOR

.300 .250 .600 $: 300$

$\begin{array}{ll}.100 & .250 \\ .100 & .250 \\ .150 & .250\end{array}$

LEGAL/INSTI TUTIONAL WEIGHTING FACTOR $=.20$ SCORE RANKING

$\begin{array}{rr}71.53 & 1 \\ 37.90 & 9 \\ 46.74 & 7 \\ 59.87 & 5 \\ 65.76 & 3 \\ 67.48 & 2 \\ 61.18 & 4 \\ 34.91 & 10 \\ 41.71 & 8 \\ 48.57 & 6\end{array}$
SCORE RANKINE

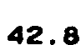
42.85 50.33 58.64

51.84

47.96

47.96

53.89

48.96
63.08

Source: SRI estimates 
These weighted values are then summed to obtain the score for each impact area. The score for each of the four impact areas is then multiplied by the assigned weighting for that impact area (1isted at the top of the table under each heading) and summed to obtain the final score or final ranking of the subbasins. With this procedure, the most favorable subbasins are:

$\begin{array}{cc}\text { Rank } & \text { Subbasin No. } \\ 1 & 1702 \\ 2 & 304 \\ 3 & 602 \\ 4 & 306 \\ 5 & 302\end{array}$

General Area

Eastern Oregon and Washington

Eastern Georgia

Northern Alabama/Mid-South Tennessee

Northern Florida

South Carolina and Eastern North Carolina

The results in Table VII-6 are portrayed graphically in Figure VII-2 which gives an indication of the geographical distribution of the favorable and less favorable basins for biomass farming. In this case, four of the five basins in northern states were ranked in the bottom four. The other northern basin, 1702 in the Pacific Northwest, was ranked number one. The Southeast was clearly identified as a favorable area for biomass farming.

\section{Indicators Equally Weighted}

If each indicator is equally weighted and the impact areas are assigned weights designed to reflect this equal weighting, the top-ranked subbasins are as shown below.

Rank Subbasin No.

$\begin{array}{rr}1 & 1702 \\ 2 & 306 \\ 3 & 701 \\ 4 & 304 \\ 5 & 602\end{array}$

These results are reported in detail in Table VII-7.

General Area
Eastern Oregon and Washington Northern Florida Mid- Wisconsin Eastern Georgia Northern Alabama and Mid-South Tennessee

\section{Impact Areas Equally Weighted}

As shuwu in Table VII-8, if impact arcas are equally weighted and indicator values are assigned weights designed to reflect this equal weigliting, the top ranked subbasins are as shown in the follnwing tabulation. 


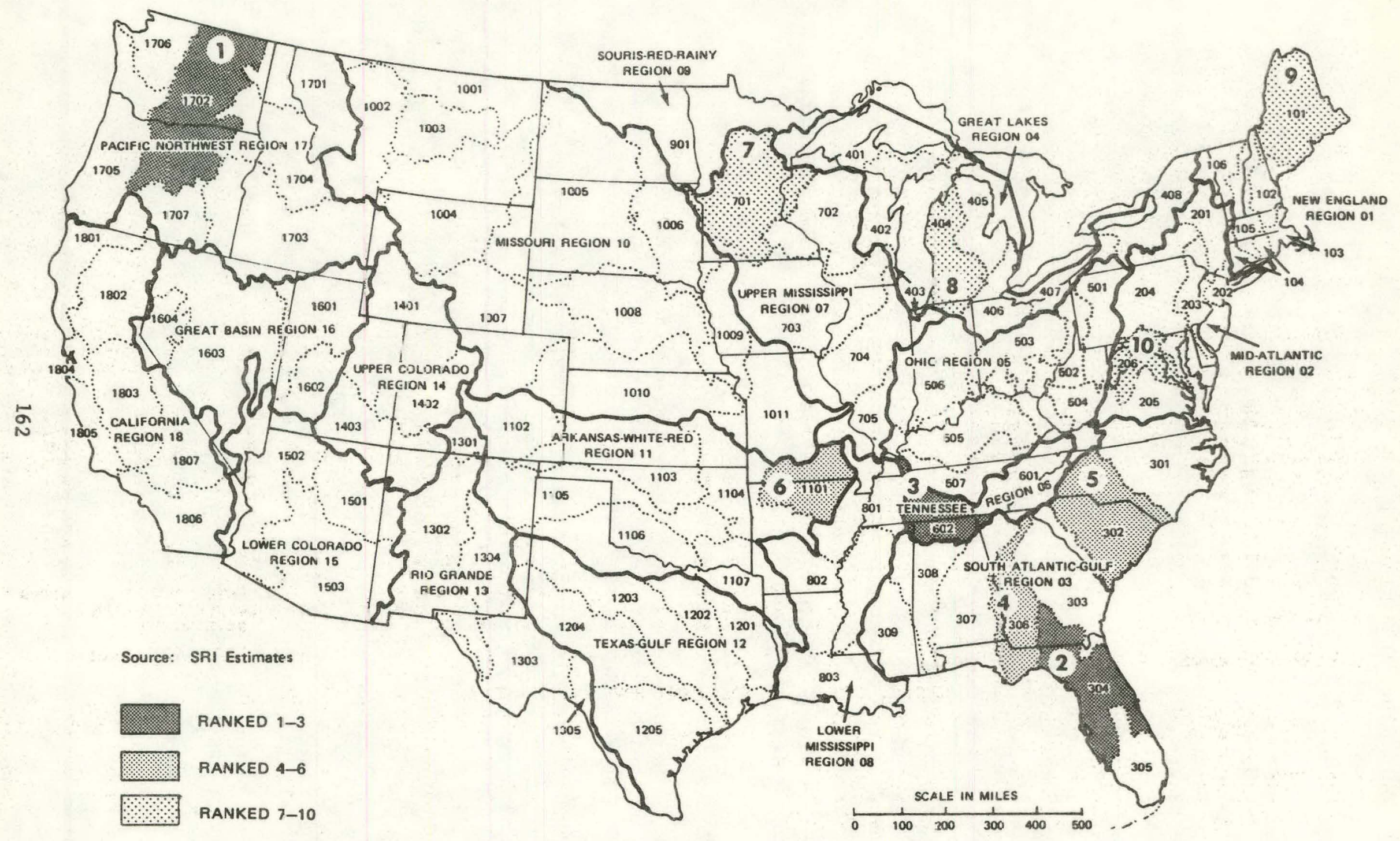

FIGURE VII-2. FINAL RANKING OF STUDY AREAS 
Table VII-7

SUMMARY OF RESULTS IF EACH INDICATOṚ IS EQUALLY WEIGHTED

\begin{tabular}{|c|c|c|c|c|c|}
\hline BASIN & $\begin{array}{r}\text { ECOI } \\
\text { WEIOHTINO } \\
\text { SCORE }\end{array}$ & $\begin{array}{l}\text { NOHICS } \\
\text { FACTOR = .31 } \\
\text { RANKING }\end{array}$ & & $\begin{array}{r}\text { EHVI RO } \\
\text { WEIOHTINO } \\
\text { SCORE }\end{array}$ & $\begin{array}{l}\text { DNMENTAL } \\
\text { FACTAR = } \\
\text {. RANR.I NO }\end{array}$ \\
\hline $\begin{array}{l}101 \\
206 \\
302 \\
304 \\
306 \\
.404 \\
602 \\
701 \\
1101 \\
1702\end{array}$ & $\begin{array}{r}58.63 \\
69.50 \\
72.16 \\
65.78 \\
67.49 \\
37.36 \\
64.96 \\
53.75 \\
63.24 \\
.58 .65\end{array}$ & $\begin{array}{r}8 \\
2 \\
1 \\
4 \\
3 \\
10 \\
\cdot \quad 5 \\
9 \\
9 \\
6 \\
7\end{array}$ & & $\begin{array}{l}32.71 \\
27.11 \\
30.46 \\
45.44 \\
53.05 \\
56.84 \\
37.65 \\
90.87 \\
40.52 \\
91.44\end{array}$ & $\begin{array}{r}8 \\
10 \\
9 \\
5 \\
4 \\
4 \\
3 \\
3 \\
7 \\
2 \\
2 \\
6 \\
1\end{array}$ \\
\hline
\end{tabular}

ECENOMICS INDICATOR WEIGHTINO FACTORS ARE

ENVIRONMENTAL INDICATER WEIGHTING FACTORS ARE

LEGAL/INSTI TUTIONAL INDICATOR WEIOHTINO FACTORS

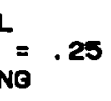

\begin{tabular}{|c|c|c|}
\hline $\begin{array}{r}\text { SOCIOE } \\
\text { WEIOHTINO } \\
\text { SCORE }\end{array}$ & $\begin{array}{l}\text { EONOMIC } \\
\text { FACTOR = } \\
\text { RANKING }\end{array}$ & .13 \\
\hline $\begin{array}{r}16.82 \\
15.79 \\
32.20 \\
33.13 \\
19.94 \\
23.61 \\
32.09 \\
16.70 \\
33.33 \\
30.57\end{array}$ & $\begin{array}{r}8 \\
10 \\
3 \\
2 \\
7 \\
6 \\
4 \\
9 \\
1 \\
1 \\
5\end{array}$ & $\because$ \\
\hline
\end{tabular}

\section{LEQAL/INSTI TUTI INAL SCORE FACTOR $=.3$}

88.70

88.70
63.01

71.75

76.30

78.78

76.00

80.93

61.97

66.58
-65.96

1
9
6
4
3
5
2
10
7
8

*** FIMAL :****

SCORE RANKINO

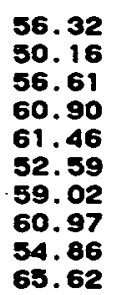

56.32
50.16
56.61
60.90
61.46
52.59
59.02
60.97
54.86
65.62
250

.250

a 
Table VII-3

SUNMARY OF RESULTS IF EACH IMPACT AREA IS EQUALLY WEICHTED

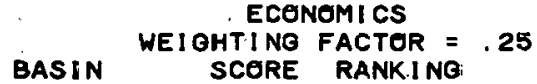

101.46 .90

$206-55.60$

404 .

$404 \quad 29.89$

$702-51.97$

101

$1702 \quad 50.59$
$304-52.62$

$306-53.62$

8
2
1
4
3
10
5
9
6
7

ENWI RONMENTAL

WEIOHTING FACTER =

SCORE RANKING

$$
\begin{aligned}
& 32.71 \\
& 27.11 \\
& 30.46 \\
& 49.44 \\
& 53.05 \\
& 56.84 \\
& 37.65 \\
& 90.87 \\
& 40.52 \\
& 91.44
\end{aligned}
$$

SOCI OECONOMIC WEIOHTINO FACTOR $=.25$

SCORE RANKING

$33.65 \quad 8$

$31.59 \quad 10$

64.41

66.26

39.89

47.22

64.18

33.40

66.67

8
10
3
2
7
6
4
9
1

ECONOMICS INDICATOR WEIOHEING FACTORS ARE

ENVIRONMENTAL INDICATOR WEIOHTING FACTERS ARE

SOCIOECONOMIC INDICATOR WEIGHTING FACTERS ARE

203

SOCI OECONOMIC INDICATOR WEIGHTING. FACTERS ARE:

.200
.250
200

.200 LEGAL: INST I TUTI IONAL NEIGHTING FACTOR $=.2$

SCORE RANKING

*** FINAL ****

SCORE RANKINO

70.96

50.40

57.40

61.04

63.02

60.80

64.74

$\begin{array}{r}49.57 \\ \hline 3.26\end{array}$

49.57
53.26

53.26
52.76

1
9
6
4
3
5
2
10
7
8

46. 05

41.17

52.50

57.34

32.49

$48: 69$

34.64

54.21

52.76
63.06 
Rank Subbasin No.

General Area

$\begin{array}{rr}1 & 1702 \\ 2 & 304 \\ 3 & 602 \\ 4 & 701 \\ 5 & 1101\end{array}$

Eastern Oregon and Washington

Eastern Georgla

Northern Alabama and Mid-South Tennessee

Minnesota

Northern Arkansas and Southern Missour1

Emphasis on Environmental Impacts

To emphasize environmental factors; the indicators shown below are most heavily weighted.

\begin{tabular}{|c|c|c|}
\hline Indicato & No. & Description \\
\hline 3 & & Irrigation of Harvested Cropland \\
\hline 4 & & Change in Energy Demand \\
\hline 6 & & Stream Density \\
\hline 7 & & Incremental Fertilizer Burden \\
\hline 8 & $\therefore$ & Ground-Water Use $:$ \\
\hline 9 & : & Nonpoint Source Pollution \\
\hline 10 & & Incremental Labor Requirement \\
\hline 11 & & Local Economy's Agricultural Base \\
\hline 13 & & Water Quality Compacts \\
\hline 14 & & Water Quality Standards \\
\hline 16 . & & Sole-Source Aquifers \\
\hline
\end{tabular}

The results for this welghting are shown in Table VII-9. The basins shown below ranked highest.

$\begin{array}{cr}\text { Rank } & \text { Subbasin No. } \\ 1 & 701 \\ 2 & 1702 \\ 3 & 306 \\ 4 & 304 \\ 5 & 404\end{array}$

General Area

Minnesota

Eastern Oregon and Washington

Western Georgia

Northern Florida

Western Michigan

Emphasis on Advantägeous Blomass Production Factors

If factors advantageous to biomass production are emphasized, the subbasins are ranked as. shown in Table VII-10. For this analysis, the indicators listed below were weighted most heavily.

Indicatui No.

Deccription

1

Potential Energy Value of New Energy Farms

Change in Energy Demand

Added Yleld because of Seasonality

Incremental Labor Requirement

10

Local Economy's Agricultural Base

11

Size of Farms 
Table VII-9

SUYMARY OF RESULTS IF INDICATORS MEASURING ENVIRONMENTAL IMPACTS ARE HEAVILY WEIGHTED

\begin{tabular}{|c|c|c|c|}
\hline BASIN & $\begin{array}{l}\text { ECON } \\
\text { WEIOHTINO } \\
\text { SCERE }\end{array}$ & $\begin{array}{l}\text { NOMICS } \\
\text { FACTOR = } .22 \\
\text { RANKING }\end{array}$ & $\begin{array}{l}\text { ENVI R. } \\
\text { WEI OHTINE } \\
\text { SCORE }\end{array}$ \\
\hline $\begin{array}{l}101 \\
206 \\
302 \\
304 \\
306 \\
404 \\
602 \\
701 \\
1101 \\
1702\end{array}$ & $\begin{array}{r}92.44 \\
90.89 \\
91.95 \\
68.33 \\
76.67 \\
45.46 \\
75.07 \\
57.34 \\
61.05 \\
40.20\end{array}$ & $\begin{array}{r}3 \\
2 \\
1 \\
7 \\
7 \\
5 \\
9 \\
6 \\
6 \\
8 \\
4 \\
10\end{array}$ & $\begin{array}{r}65.42 \\
54.22 \\
60.93 \\
58.89 \\
166.09 \\
113.69 \\
75.30 \\
181.74 \\
81.03 \\
182.87\end{array}$ \\
\hline
\end{tabular}

ECONOMICS INDICATOR WEIOHTINO FACTORS ARE

ENVIRONMENTAL INDICATOR 'WEIOHTINO FACTORS ARE

INOE

LEGAL/INSTI TUTI ONAL INDILATOR WEIGHTINGI FAC-ORS

.120
.500
.500
.120

SOCIOECONOMIC

SCITINO FACTOR $=.16$
SCORE RANKINE

$\begin{array}{rrr}8 & 33.65 & 8 \\ 10 & 31.59 & 10 \\ 9 & 64.41 & 3 \\ 5 & 66.26 & 2 \\ 4 & 39.89 & 7 \\ 3 & 47.22 & 6 \\ 7 & 64.18 & 4 \\ 2 & 33.40 & 9 \\ 6 & 66.67 & 1 \\ 1 & 61.13 & 5\end{array}$

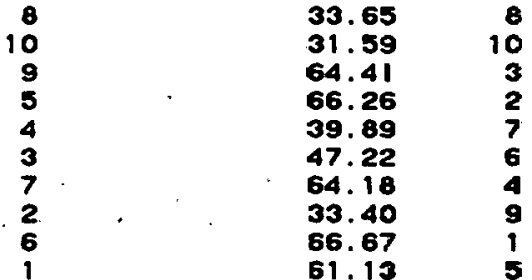

10

$\begin{array}{lll}.125 & .500 & .500 \\ .500 & .500 & .500 \\ .500 & & \\ 500 & .500 & .250\end{array}$

$500.500:-250$
INSTITUTI ONAL SCORE RANKINO

135.68
106.01
120.46
118.77
123.00
127.44
131.80
111.83
55.91
89.14

1
6
5
6
4
3
2
7
9
10
SCORE RANKINO

85. 16 74.20 86. 17 92. 91 94.10 92.17

90.42

109.66

83.20
103.89

.125

.500

مू 
Table VII-10

SUMMARY OF RESULTS IF INDICATORS MEASURING

FUTURE BIOMASS PRODUCTION LEVELS ARE HEAVILY WEIGHTED

\begin{tabular}{|c|c|c|c|c|}
\hline BASBM & \multicolumn{2}{|c|}{$\begin{array}{l}\text { ECONOMI CS } \\
\text { WEIOHTINO FACTOR = .36 }\end{array}$} & \multicolumn{2}{|c|}{$\begin{array}{l}\text { ENWI RONMENTAL } \\
\text { WEIGHTINO FACTOR }=.15 \\
\text { SCORE. RANKINO }\end{array}$} \\
\hline $\begin{array}{r}101 \\
206 \\
302 \\
304 \\
306 \\
404 \\
602 \\
602 \\
701 \\
1101 \\
1702\end{array}$ & $\begin{array}{r}68.20 \\
110.36 \\
103.17 \\
118.04 \\
109.25 \\
43.40 \\
73.62 \\
64.12 \\
83.99 \\
77.90\end{array}$ & $\begin{array}{r}8 \\
2 \\
4 \\
1 \\
3 \\
10 \\
107 \\
\quad 79 \\
5 \\
6\end{array}$ & $\begin{array}{l}23.04 \\
22.04 \\
24.05 \\
36.22 \\
36.43 \\
45.76 \\
24.63 \\
67.29 \\
37.27 \\
70.72\end{array}$ & $\begin{array}{r}9 \\
10 \\
7 \\
6 \\
5 \\
3 \\
8 \\
2 \\
4 \\
1\end{array}$ \\
\hline
\end{tabular}

ECONOMICS INDICATOR WEIGHTINO FACTORS ARE ENVIRONMENTAL INDICATOR WEIBHTINO FACTORS ARE SOCIOECONOMIC INDICATOR MEIGHTINO FACTORS ARE
LEOAL/INSTITUTIONAL INDICATOR HEIOHTINO FACTORS

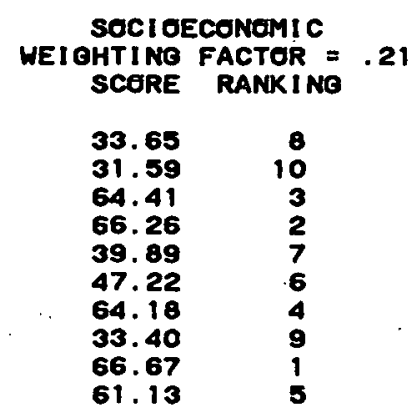

.125
.125
.500
.250

.125
.250
.250

.250
LEGAL/INSTI TUTI IONAL WEIOHTING FACTOR $=.28$ SCORE RANKINO

*** FINAL **:*

90.56

70.93

79.41

93.45

96.40

66.43

75.03
64.15

64.1 .5

65.46

87.71

3
7
5
2
1
6
6
10
9
4

SCORE RANKINO

$\begin{array}{rr}60.47 & 6 \\ 69.49 & 8 \\ 76.43 & 3 \\ 87.89 & 1 \\ 80.19 & 2 \\ 51.04 & 10 \\ 64.54 & 7 \\ 58.32 & 9 \\ 68.02 & 6 \\ 76.12 & 4\end{array}$


With this procedure, the top-ranked subbasins were those listed below.

Rank Subbasin No.

General Area

$\begin{array}{rr}1 & 306 \\ 2 & 304 \\ 3 & 302 \\ 4 & 1702 \\ 5 & 206\end{array}$

\author{
Northern Florida \\ Eastern Georgia \\ South Carolina and Eastern North Carolina \\ Eastern Oregon and Washington \\ Northern Virginia and Eastern Maryland
}

\title{
Emphasis on Encrgy Farm Opcrating Costs
}

If factors leading to low operating costs for energy farms are emphasized, the subbasins are ranked as shown in l'able VI1-1L. To emphasize this factor, the following indicators are most heavily weighted.

Indicator No.

2

5

11

12
Description

Cost of Agricultural Land

Added Yield because of Seasonality

Local Economy's Agricultural Base

Size of Farms

With this procedure, the top-ranked subbasins were those shown in the tabulation that follows.

$\begin{array}{cr}\text { Rank } & \text { Subbasin No. } \\ 1 & 1702 \\ ? & 304 \\ 3 & 306 \\ 4 & 302 \\ 5 & 1101\end{array}$

General Area
Eastern Oregon and Washington
Eastern Georgia
Northern Florida
South Carolina and Eastern N. Carnlina
Northern Arkansas and Southern Missouri

Summary

The study results identify the Southeașt as a favorable area for biomass farming, but the Northwest should also be considered because of its very favorable environmental characteristics. Subbasin 1702 (Eastern Oregon and Washington) ranked in the top five in every comparison made during the analysis. When factors measuring favorable biomass yield and other similar production indicators are weighted heavily, the Northwest does not compare quite as favorably, but it still ranks fairly high.

The ranking methodology described in this section provides an easy, semiquantitative method for comparing dissimilar: regions on a similar basis and permits extensive sensitivity analyses of the results. It is comparative and does not provide an absolute measure of desirability, but it makes it possible to compare any number of subbasins with each other and rank their desirability as sites for developing biomass farms. 
Table VII-11

SUMMARY OF RESULTS IF INDICATORS MEASURING ENERGY FARM OPERATING COSTS ARE HEAVILY WEIGHTED

\begin{tabular}{|c|c|c|c|c|}
\hline BAS IN & $\begin{array}{l}\text { WEI OHT INO } \\
\text { SCORE }\end{array}$ & $\begin{array}{l}\text { FACTOR }=.34 \\
\text { RANKINO }\end{array}$ & $\begin{array}{l}\text { WEI GHTINO } \\
\text { SCORE }\end{array}$ & $\begin{array}{l}\text { FACTER = } \\
\text { RANKING }\end{array}$ \\
\hline $\begin{array}{l}101 \\
206 \\
302 \\
304 \\
306 \\
404 \\
602 \\
701 \\
1101 \\
1702\end{array}$ & $\begin{array}{l}73.89 \\
55: 87 \\
91: 50 \\
90: 49 \\
92: 42 \\
44.95 \\
64: 81 \\
50: 48 \\
84.29 \\
79: 43\end{array}$ & $\begin{array}{r}6 \\
8 \\
2 \\
3 \\
1 \\
10 \\
7 \\
9 \\
4 \\
5\end{array}$ & $\begin{array}{r}23.04 \\
22.04 \\
24.65 \\
36.22 \\
36.43 \\
45.76 \\
24.63 \\
67.29 \\
37.27 \\
70.72\end{array}$ & $\begin{array}{r}9 \\
10 \\
7 \\
6 \\
5 \\
3 \\
8 \\
2 \\
4 \\
1\end{array}$ \\
\hline
\end{tabular}

SOCIOECONOMIC

WEIOHTINO FACTOR $=.17$

SCORE RANKINO

$$
\begin{array}{r}
33.43 \\
7.90 \\
29.69 \\
31.79 \\
20.33 \\
23.55 \\
41.74 \\
28.42 \\
49.00 \\
51.21
\end{array}
$$

LEOAL/INSTI TUTI IONAL

WEIOHTINO FACTOR = 31

SCORE RANKINO

90.56

70.93

79.41

93.45

96.40

66.43

75.03

64.15

65.46

65.46

500

.250
.250

.125
*** FINAL **:

SCORE RANKIN

$\begin{array}{rr}63.47 & 6 \\ 46.56 & 10 \\ 65.64 & 4 \\ 72.04 & 2 \\ 71.70 & 3 \\ 48.15 & 9 \\ 57.18 & 7 \\ 63.86 & 6 \\ 64.27 & 5 \\ 75.69 & 1\end{array}$

ECONOMICS INDICATOR WEIOHTINO FACTORS ARE ENVIRONMENTAL INDICATOR WEIOHTINO FACTORS ARE .125 DIOECONOMIC INDICATOR WEIOHTINO FACTORS ARE 


\section{REFERENCES}

1. U.S. Department of the Interior, 1974 Census of Agriculture (1977).

2. U.S. Water Resources Counc1l, "The Nation's Water Resources, The 'Second National Water Assessment by the U.S. Water Resources Council, Parts I-V, Appendices A and B," draft report (April 1978).

3. Srha1ler, Mepartment of Agrnnnmy, llniversity nf ralifnrnia at navis, personal communication (August 30, 1978).

4. L.B. Leopold, M.G. Wolman, J.P. Miller, Fluvial Processes in Geomorphology, W.H. Freeman and Company (1964).

5. U.S. Water Resources Council, "The Nation's Water Resources, The First National Water Assessment by the U.S. Water Resources Council,". final report (1971).

6. U.S. Department of Agriculture, "Crop Yield in Response to Fertilizer" in the U.S.," U.S. Statistical Bulletin, No. 431 (August 1968).

7. C.K. Murray and E.B. Reeves, "Estimated Water Use in the United States in 1975," U.S. Geological Survey, Circular 765 (1977).

8. A.G. Wright, U.S. Environmental Protection Agency, personal communication (January 1979). 


\section{METHODOLOGY FOR THE EVALUATION OF FUTURE ENERGY FARM AREAS AND SITES}

This section describes the qualitative ranking procedure proposed for the evaluation of future energy farm areas. The procedure has un $1-$ versal application, although it was designed for use first in selecting general areas suitable for biomass farms, and then in evaluating sites for which the specific operating objectives and desired end products have not been determined. This section first describes a general area selection procedure and then a specific site selection methodology.

\section{Selecting the General Area}

The procedure recommended for selecting a general area suitable for biomass farming follows the ranking methodology described in the previous sections. The procedure requires selecting subbasins to be compared and evaluating the selected areas on the basis of various ranking factors.

\section{Initial Screening of Subbasins}

For a first screening, the selection procedure requires using nine weighted factors to rank potential areas and eliminate the least promising. The nine factors were discussed in detail in Section $V$. They are:

(1) The amount of subbasin water available

(2) The amount of subbasin acreage available for dedicated farms

(3) The amount of subbasin acreagc available for combination crops

(4) The regional water-to-land balance

(5) The quality of area stream flows

(6) The dependence of the subbasin on fossil fuel sources

(7) The potential labor pool and expected demand for biomass products in the subbasin

(8) Availability of coal resources

(9) Area rainfall. 
As explained in Section $V$, the scoring procedure requires the following steps:

(1) Absolute values for each factor are obtained, and areas are ranked in order based on each factor.

(2) A numerical value is assigned to each area for each factor based on the ranking for that factor (for example, top-ranked $=1,000$ and bottom-ranked $=500$ or 0$)$.

(3) Weights are assigned to each factor (possible scale $=0$ to 100; most important factor weight i.s 99 or 100 ; least important factor weight is 20 or 40 ).

(4) The numerical values for each factor in an area are multiplied by the weights assigned to the factors.

(5) The resulting figures for each area are summed to obtain an overall score for the subbasins.

(6) Areas are listed in descending order of desirability on the basis of these scores.

Sixteen weighted indicators are used to select the most appropriate general area or subbasin from those that survive the initial screening procedure. These are described in detail in Section VII. The subbas in selection procedure requires ranking areas on the basis of scores calculated from weighted values for indicators shown below. (The formula required to calculate the value for each 1ndicator is also summarized below.)

(1) Fotential Energy Value--New Energy Farms (Btu)

Potential energy value of the crops = crop energy value (Btus/ton) times crop yield (tons/acre) times projected biomass crop acreage (high energy value = high ranking).

(2) Cost of Agricultural Land (Dollars per Acre)

Average cost of agricultural land = average cost per aore (10w $\operatorname{coot} w$ high ranking).

(3) Irrigation of Harvested Cropland (percent)

Pcrccnc of hariçated cropland that is irrigated $=$ acres of irrigated land divided by acres of harvested land (high percentage $=$ low ranking). 
(4) Change in Energy Demand (gigawatt-hours) by the Year 2000

Gigawatt demand in 2000 minus year 1985 gigawatt demand divided by 1985 gigawatt demand (1arge demand = high ranking).

(5) Seasonability Factor (Btu)

Incremental energy yield of the basin due to double cropping $=$. [ (energy value of new energy farms (Indicator 1) minus forestry crop energy value) times number of basin harvests minus 1] divided by energy value of new energy farms (large incremental energy yield = high ranking).

(6) Stream Density Per Square Mile (miles per square mile)

Cumulative length of all streams (miles) divided by area of the basin in square miles (high density = low ranking).

(7) Incremental Fertilizing Burden: (pounds per acre) or Amount of Phosphorus and Nitrogen Applied per Acre

Rate of nitrogen and phosphorus application per acre per year times projected biomass crop acreage in 2000 divided by total current harvested acreage in the basin (high fertilizer per acre $=1$ ow ranking).

(8) Percent of Domestic Water Supplied by Ground Water

Volume of ground water used as domestic supply (million gallons per day) divided by volume of all water used as domestic supply (millions of gallons per day) (high percentage $=$ low ranking).

(9) Nonpoint Source Pollution

Short tons of current land erosion caused by rainfall per acre per year (high erosion rate = low ranking).

(10) Incremental Labor Requirement

Labor force needed for new energy farm crops in $2000=$ projected new biomass crop acreage in year 2000 times total 
hired farm workers per acre within the basin (high labor force increases $=$ high rankings).

(11) Percent of Local Economy Based on Agriculture

Total agricultural and forestry earnings divided by total earnings of all sectors (high percentage $=$ high ranking).

(12) Size of Farms or Percent of Acreage Devoted to Large Farms

Amount of acreage in farms more than 1,000 acres in size divided by amount of acrcagc in farms larger then 50 acres in size (high percentage of läge tarms $=$ high. ranking).

(13) Number of Water Quality Compacts

(Large number $=$ low ranking.)

(14) Water Quality Standards

Percentage of stream miles that do not meet water quality standards (high percentage = low ranking).

\section{(15) Permits (days)}

Minimum amount of time required to obtain ground-and surface-water permits = minimum time to obtain surfacewater permits plus minimum time to obtain ground-water permits (low total time requirements = high ranking).

(16) Sole Source Aquifers

Percentage of basin area that lies over sole source aquifer = area of sole source aquifer within the basin (square miles) divided by area of the basin in square miles (high percentage $=$ low ranking).

Weights for each indicator, on a scale of 0 to 100, are determined on the basis of individual study objectives or the purpose of operating requirements of the proposed facility.

A manual of work sheets for evaluating alternative biomass production areas is provided in Appendix $F$. The forms provide a convenient method of accumulating subbasin data for use in comparisons. Appropriate sources of subbasin data for each indicator are shown on the forms. 


\section{Other Factors to Consider}

Other factors to be considered when comparing areas within a subbasin include those listed below.

- Skills avallable in the area

- Existence of state-sponsored training programs

- Local financing options

- Tax incentives and exemptions

- Land gifts, grants, and development incentives

- State construction costs

- Transportation requirements

- Availability of plant design assistance

- Avallable sites and buildings

- Avallability of market analysis services.

The importance of these factors must be determined subjectively. Data on the factors can be obtained from state, local, or national agencles. The nature of each factor and possible sources of information on them are discussed below.

Skills Available in the Area. Detailed information on the number of experienced employees in each state, tabulated by sex, work status, and education, is published by the U.S. Department of Commerce. This information provides a detalled breakdown of skill avallability by position lin the fulluwlug general caregorles:

- Professional, technical, and kindred workers

- Managers and administrators (nonfarm)

- Sales workers

- Clerical and k1ndred workers

- Craftsmen and kindred workers

- Operative (except transport)

- Transport equipment operatives

- Laborers (nonfarm)

- Farmers and farm managers

- Farm laborers and farm foremen

- Service workers (except private household workers)

- Private household workers. 
The avallability of various kinds of skills varies slgnificantly. from state to state. For example, in 1970, Alabama, with 749,851 employed males in its work force, had three times as many precision machine operatives $(3,015)$ than its neighbor, Louisiana $(803)$, although Loulsiana's employed male work force of 749,825 was about the same as Alabama's. 1

Existence of State-Sponsored Training Programs. It is often argued that unemployment creates a significant pool of labor for new industry, but this is only true if appropriate skills are available or statesponsored training programs are provided. Almost all the states provide. support for the training of industrial employees, but the amount of support varies. Certain states provide only technical and craft-related courses in publis srhnnls. arhers provide dll the ilistructors and engineering personnel necessary to develop the skills required to staff a new plant, thus helping to decrease start-up losses and labor turnover for owners of new plants.

Local Financing Options. Some states and territories offer developmental loans of up to 100 percent of a property's (real estate and equipment) appraised value. Most states offer revenue bond financing, and 26 states offer financial aid for expansions of existing plants. Under a typical industrial revenue bond financing plan, the land, building, and equipment procured under the bond issue remain the property of the issuing municlpality and are leased to the user. Thus, the plant is not subject to ad valorem taxes, which creates a substantial saving for the user company. 2

Tax Incentives and Exemptions. Six states provide a tax exemption to encourage research and development and 21 states provide a tax exemption or moratorium on new equipment ò machinery purchases. Seventeen states provide a tax exemption or moratorium on the purchase of land or capital improvements and eight states provide for an exc1se tax exemplluil. Seventeen states provide for a corporate income tax exemption and 15 states provide for accelerated depreciation on industrial equipment. Thlrty-eight states offer an inventory tax exemption on goods in transit (freeport laws).2,3

Land Gifts, Grants; and Development Incentives. In 14 states, city, county, or state agencies encourage facility development by offering gifts of land to new industry. S1te costs normally range from zero to $\$ 90,000$ per acre in industrial parks, depending on the location, the local incentive program, and the type of company operation. ${ }^{4}$ Land development incentives are provided in various forms, such as outright grants, extension of utilities, and road construction. Again, these are dependent upon company operations, local programs, and conditions. 
State Construction Costs. The F.W. Dodge Corporation cost index compares construction costs in the principal cities of 48 states, based on a value of 100 for New York City. According to this index, South Carolina has had the lowest or second lowest construction costs in the nation for many years. Thirteen states have a construction cost index of 75 or less.

Transportation Requirements. The economic and physical effects of transportation and distribution requirements, as well as the availability of transportation in a region, must be analyzed on an individual basis. for each proposed location. A great deal of general transportation information useful to the potential site owner is available. from the states. This includes information on highways, railroads, trucklines, airlines, ports, and waterways, as well as data on rates, terminal facilities, transit schedules, interchanges, and state services. However, only a detailed analysis of the owner's specific requirements for shipping volume, incoming component quantities, product destinations, warehousing, and expected subcontractor or supplier locations will provide the data necessary to choose an economical plant location. ${ }^{4}$

\section{Avallability of Plant Design Assistance}

Eight states provide assistance in the design of new plants, usually at no cost or at a very nominal cost to cover operating expenses and supplies. The following states offer this service, according to the U.S. Department of Commerce:
- Alabama
- Arizona
- Connecticut
- Indiana
- Maine
- Nevada
- Oklahoma
- South Dakota.

Avallable Sites and Buildings. Many states and regional development agencies provide current listings of available industrial sites and buildings, aerial and topographic plats, highway and rail maps, site layouts, building specifications, pictures, and plot plans. In addition, data on zoning, utilities, ceiling clearances, structural type, rail service, and truck docks, as well as on complete industrial parks and districts, is also available. Many staces provide an annual building and site directory.

Availability of Market Analysts Services. Many states provide helpful information on population, income, sales, production, and value added by manufacturing indices by city, county, and state. States also provide valuable information on retail and wholesale trade patterns, service industries, and local industrial markets. 
In most cases, these factors apply to the analysis of candidate areas, although a few factors will also be important in choosing specific sites. SRI's recommended procedure for analyzing specific crop production and conversion site alternatives is described in the next subsection.

\section{Selecting the Specific Site}

The procedure for selecting the specific site within a subbasin requires five steps: (1) an analysis of potential feedstocks and biomass fuel products; (2) a market study; (3) a technical feasibility and resource avallability analysis; (4) a cost, revenue, and rate of return analysis; and (3) preliminary design and a rate of return recalculation'.

The procedures to follow and the objectives of each of these steps is summarized in the paragraphs that follow.

\section{Step 1--Product Potential (Supply) Analysis}

This first step requires the identification of all potential biomass production (energy farm) sites in the subbasin and a determination of the most likely type of crop and biomass fuel end product appropriate to each site. Considering the diverse character of most subbasins, it is likely that several crop combinations, alternative feedstocks, and fuel product candidates will be identified. Potential crop yields and conversion site efficiencies should be estimated, and the end result of the analysis should be a projection of the potential availability of biomass fuel supplies over time for each site.

\section{Step 2--Market (Demand) Study}

The next step, the market study, is designed to identify the character of the end product fuei demand. A successful market survey will quantify fuel needs over time and identify requirements for new plant capacity to meet local and remote demands. A comparison of fuel demands with potential fuel supplies. from each proposed energy farm site will narrow the number of feasible alternatives for further analysis. At this point numerous (possibly 5 to 50 ) potential sites in each subbasin could be candidates.

\section{Step 3--Technical Feasibility Analysis}

The purpose of the Step 3 analysis is to provide assurance that the production concept is workable and that all needed resources will be available for the proposed project. In addition, environmental impacts associated with development of each proposed site should be determined and evaluated. 
Step 3 includes a detailed study of production requirements and the means for delivery of necessary resources, including raw materials, equipment, operating supplies, labor, materials, power, transportation, facility components, and utility needs. Processes should be described, flow charts prepared, and mass and material balances calculated. In addition, compliance with environmental standards should be assured. An environmental impact statement (EIS) is a procedural requirement for the U.S. Environmental Protection Agency mandated by P.L. \#90-190, the National Environmental Policy Act (NEPA). Several states have adopted similar requirements, either by law or as regulations. Although the preparation of an EIS is always the duty of a government official, the private applicant for a permit, lease, or funding must provide much of the required information. Thus, a specific effort must be made to learn about and evaluate air, water, solid waste, and nolse pollution standards in each area.

As a result of the Step 3 effort, it is likely that the number of candidate sites will be reduced significantly because a number of $1 \mathrm{im}-$ itations will make it difficult for many areas to meet the technical requirements of the proposed facility.

\section{Step 4--Cost, Revenue, and Rate-of-Return Analysis}

The next step requires a rough order-of-magnitude, rate-of-return analysis to further screen potential sites. This effort requires the development of a conceptual production site and plant design and the preparation of budgetary cost and revenue projections. Estimates of feedstock production, transportation, facility investment, and project operating costs should be included, and revenues should be computed on a discounted cash flow or regulated utility basis as appropriate. At this point, biomass product revenue requirements should be compared with conventional fuel price projections to further define potential biomass fuel market penetration. A rate of return on capital investment should also be calculated for each candidate aite and compared with established guidelines to further define its economic soundness. We anticipate that the number of alternative sites will be further reduced at the completion of this step--perhaps only one or two candidates will remain. At the completion of Step 4, land purchase options should be obtained to ensure that feasible candidate sites can be acquired in the future.

\section{Step 5--Preliminary Design and Return on Investment Recalculations}

The purpose of this step is to further define project requirements and verify the economic feasibility of the projects. The step involves the preparation of prelfminary construction plans, specifications, and designs, and detailed reestimation of proposed site investment and operating costs. Recalculation of project costs, revenue requirements, and rates of return on investment are required prior to actual size acquisition (1.e., exercise of a purchase option). 
Each of these five steps can be performed at different levels of effort and sophistication, depending upon evaluation budgets; in general, the amount of time and.funds expended will increase as the number of candidate sites increases and the level of analysis and study detail intensifies. Because a great deal of funding and effort could be devoted to Steps 4 and 5 , the number of site alternatives should be reduced as much as possible before these Steps are reached.

In some cases a preliminary pilot plant or laboratory-scale operation will be necessary to refine process designs and production and conversion concepts. In these cases, several of the five site-selection steps may have to be repeated for each operational concept.

Valuable information for use in analyzing U.S, biomass resources, conversion economics, products, and markets is available in numerous source documents. 5-16 


\section{REFERENCES}

1. Bureau of International Commerce, "Miscellaneous Economic Data by States and Regions," U.S. Department of Commerce, Bureau of the Census $(1970)$.

2. Office of International Investment, "States Providing General Assistance, Incentives and Special Services to Industry," U.S. Department of Commerce (March 1973).

3. Bureau of International Commerce, "State Tax Table (State Tax Sources and Rates)," U.S. Department of Commerce (March 1972).

*4. F. A. Schooley, "Real Estate Planning and Location Analysis," Stanford Research Institute, Menlo Park, California (1974).

* 5. J. A. Alich, Jr., R. E. Ihman et al., An Evaluation of the Use of Agricultural Residues as an Energy Feedstock, Vols. 1 and 2 (July 1976).

*6. K. A. Miller, "Program Definition for Fuels from Biomass" (October 1976).

*7. K. A. Miller, "Refuse as a Fuel for Utilities" (April 1974).

*8. K. A. Miller and J. A. Alich, Jr., "Feastbility of Co-Firing Agricultural Residues in a Coal-Fired Electric Power Plant in the Sacramento Valley" (September 1977).

*9. F. A. Schooley, J. A. Alick, Jr., and R. K. Ernest, "A Preliminary Analysis of the Potential Feasibilicy of Ut1lizlug Agricultural Residues in the Sutter County, California, Area for the Production of Energy" (September 1976).

${ }^{*}$ 10. J.'A. Alich, Jr., and R. E. Inman, "Effective Utilization of Solar Energy to Produce Clean Fuel" (June 1974).

${ }^{*}{ }^{* 1}$. F. A. Schooley, J. A. Alich, Jr., et a1., Crop, Forestry and Manure Residue Inventory--Continental United States, 8 Volumes (June 1977).

${ }^{*}{ }^{*}$ 12. F. A. Schooley, J. A. Alich, Jr., R. K. Ernest, K. A. Miller et al., An Evaluation of the Use of Agricultural Residues as an Energy Feedstock--A Ten Site Survey, 2 Volumes (June 1977).

†13. F. A. Schooley, J. G. Witwer et al., "A Comparative Evaluation of Sular Alterinatives: Implieations for Federal R\&D," SRI International, Menlo Park, Californla (January 1978). 
*14. R. K. Ernest, "Preliminary Analysis of Agricultural Residues Produced in Ten California Counties" (August 1977).

15. F. A. Schooley, R. L. Dickenson, J. Jones, R. K. Ernest, Mission Analysis for the Federal Fuels from Biomass Program, 6 Volumes, SRI International, Menlo Park, California (January 1979).

16. J. P. Miller and F. A. Schooley, "Availability and Cost of Agricultural and Municipal Residue for Use in Alcohol Fuel Feedstocks," SRI International, Menlo Park, California (December 1978).

\footnotetext{
* These reports were all published by Stanford Research Institute, Menlo Park, California.

'Avallable from the National Technical Information Service, 6285 Port Royal Road, Springfield, Virginia 22161.
} 
Appendix A

METHODOLOGY FOR ESTIMATING WATER USE AND PROJECTED

STREAMFLOWS--SECOND NATIONAL WATER ASSESSMENT 
i

THIS PAGE

WAS INTENTIONALLY

LEFT BLANK 
Appendix A

METHODOLOGY FOR. ESTIMATING WATER USE AND PROJECTED

STREAMFLOWS--SECOND NATIONAL WATER ASSESSMENT

\section{Water Use Projections}

Water use projections in the Second National Water Assessment by the U.S. Water Resources Councill were developed by a variety of federal agencies. This appendix provides a brief summary of the methods used for determining current and future requirements for water-use sector.

\section{Domestic-Central}

This water use relates to individuals served by public water supply systems. Basic data were obtained from the USGS. Per capita use rates were assumed to remain constant. Monthly variation in water requirements was calculated for five geographic regions: Northeast, Southeast and Islands, Great Plains and Rocky Mountains, West, and Alaska.

\section{Domestic-Noncentral}

This water use relates to individuals served by their own private water supply. Census of Housing data were used to determine the number of housing units with self-supplied systems. Census of Housing data for 1960. and 1970 were reviewed to determine the trend toward central water supply systems by state. Declines of 1.0 to $2.25 \%$ were used in making the projections. Separate estimates of water use were made for houses with running water and for those without running water.

\section{$\underline{\text { Industrial }}$}

A forecasting model for water use was developed by the office of Business Policy Analysis (formerly Office of Business Research and Analysis, OBRA), Bureau of Domestic. Business Development. The OBRA data base has water-use information on 9,300. large manufacturing plants, the OBERS file of reginnal economic activity, and information on technical coefficients for recirculation rates and consumption rates. Assumed future conditions included zero discharge of pollutants in the year 2000 and economic growth according to OBERS Series E projections. Average water consumption rates for 37 water-intensive Standard Industrial Code (SIC).4-digit industries were calculated assuming that "wet" conling towers are used to recirculate heated wastewaters. Discharge to 
holding ponds was assumed to discontinue. Gross water use per dollar of gross product was assumed to remain constant for each SIC 2-digit industry, as it has over the past 20 years.

\section{Minerals}

OBERS Series E projections were assumed for three major mineral groups: metals, nonmetals, and fuels. National averages of water withdrawal were estimated in gallons per production dollar for each group. The estimates for energy fuels do not reflect the changing requirements necessary for development of new energy sources, nor do they consider acceleration of development of nonfuel minerals.

\section{$\underline{\text { Irrigation }}$}

Monthly and annual irrigation water-use coefficients for normal and dry years were developed by the Soil Conservation Service. Estimates of crop consumptive irrigation requirements, irrigatiun system conveyance efficiency, and on-farm efficiency were developed on the basis of recent trends toward improved irrigation systems and management. Esllillates of irrigated crop acreage were based on levels of economic,growth projected by OBERS Series E. All of this information was incorporated in the Iowa State. University linear programming model. Agricultural Resourçe Assessment System, which provided estimates for each subbasin of land use, water use, commodity production, value of prodiction, agricultural iu= come, employment, land and water conservation, and soil erosion.

\section{$\underline{\text { Livestock }}$}

Water use rates for drinking were based on published reporto, pasture and range conditions, temperature zones, and type of animal. Water use rates for nondrinking livestock needs included cvaporation from stockwater ponds, dairy accumulation and waste disposal, watering losses, and egg washing, and they were estimated on the basis of information in published reports, special area studies, and complered river basin sludies. Estimates of future livestock production were derived from the central case in the 1972 OBERS report. Seasonal variatinns in water requilemenis werè assumed.

\section{Electric. Power}

Estimates of monthly and annual electric energy consumption for each identifiable load segment were developed by the Federal Energy Regulatory Commission (FERC). Expected changes reflected scheduled major load changes, load saturation, area economic changes, demographic changes, and the effects of energy conservation efforts, higher electric rates, the substitution of electricity for scarce fossil fuels, and 
other factors. Generating capacity was determined from existing and planned capacity scheduled for operation by class of service--base load, intermediate, and peaking. Scheduled retirements were subtracted. If necessary, units were selected to augment the system by analyzing load duration curves and selecting capacity types that would give an optimal mix. The selection of growth rates was based on OBERS Series E projections. Estimates of monthly and annual water use for normal and dry years at steam-electric plants were based on selection of the type of condenser cooling expected to be used at each plant and estimates of water use in each type of plant for the various types of cooling. Most new plants were projected to use wet cooling towers or cooling ponds. Where ground water is used, return flows were assumed to be discharged to surface-water sources. Dry year conditions were estimated for subbasins in which approximately $20 \%$ or more of the total generation is supplied by hydroelectric power.

\section{National Parks}

Estimates of monthly and annual water used were made by the National Park Service and based on existing metered records, published reports, and park visitation records. Projected rates were estimated on the basis of OBERS Series E population growth and capacity levels for individual parks.

\section{National Fish Hatcheries}

USFWS estimated water requirements on the basis of present and future fish production schedules for 94 National Fish Hatcheries. These were assumed to account for $10 \%$ of the total fish production effort in the nation. Information contained in the annual reports of the hatcheries were used to determine water use rates. Future improvements in production methods were assumed.

\section{Public Lands of the Bureau of Land Management}

Water requirements for resource uses were derived from current and projected levels of operation on the various management and evaluation areas except for minerals. Specific activities included were: wildlife, watershed (irrigation), timber, recreation, fire protection, construction and maintenance, and impoundments. Unit water requirements were estimated for each activity, such as water use per day, or gallons of water used per acre burned. Future activity levels were selected to parallel the OBER Series E projections.

\section{National Forests}

The U.S. Forest Service estimated current and projected water use on the basis of regional inventories nf water use and water rights for 
each National Forest in the West and on general water requirements per acre in the East. OBERS Series C projections were used to help predict future activity because Series E projections were not available at the time. It was assumed that recreation and grazing demand would increase slightly over time and that ground water use will increase proportionally over time.

\section{Instream Requirements for Fish and. Wildlife}

Water requirements for fish and wildlife were based on instream flows and the amount of water necessary for maintaining non-riverine aquatic and terrestrial ecosystems. These water requirements are closely related to and interdependent with other instream requirements sush as recreation, liavigdliul, liydrupuwer generacion, and ecosystem maintenance. Furthermore, water management activities for flood control, erosion and sedimentation control, and irrigation greatly affect the success of fish and wildife, especially if the needs may become competitive rather than complementary.

Approximations of instream flow requirements were developed by a team of USFWS biologists on the basis of USGS water supply statistics applying professional judgment to available data. The methods employed in the estimations varied significantly by geographic region. The combination of factors considered included: nature of the ecosystem; relative water supply as influenced by hydrological conditions, storage, and past allocation of supplies; and availability of previous studies applicable for use in the assessment. Figure A-1 depicts the method used in each subbasin.

Water Supply Adequacy Analysis Model

The projected streamflows in each subbasin for 1985 and 2000 were developed on the basis of a conception of balance betwepn water requirements and water supply availability that includes some consideration of ground water. The model describing the inputs and outputs is shown in Figure A-2. Reductions in streamflow include interbasin exports, consumption, and evaporation. Streamflow measurements collected by USGS in 1975 from gauging stations were used as the basis for the projections. For the period of analysis, precipitation was assumed to be constant, and eetrmaces of watcr imports and exports are based unly un those that would occur from authorized and funded projects. Ground-water mining, which occurs when ground water is withdrawn at a faster rate than it is replenished, was assumed to be discontinued in the future. The excess water demand formerly obtained from mining of ground water was then assumed to be obtained from the surtace-water supply. The eight components of the model are discussed below (WRC, Part IV, draft report, 1978). 


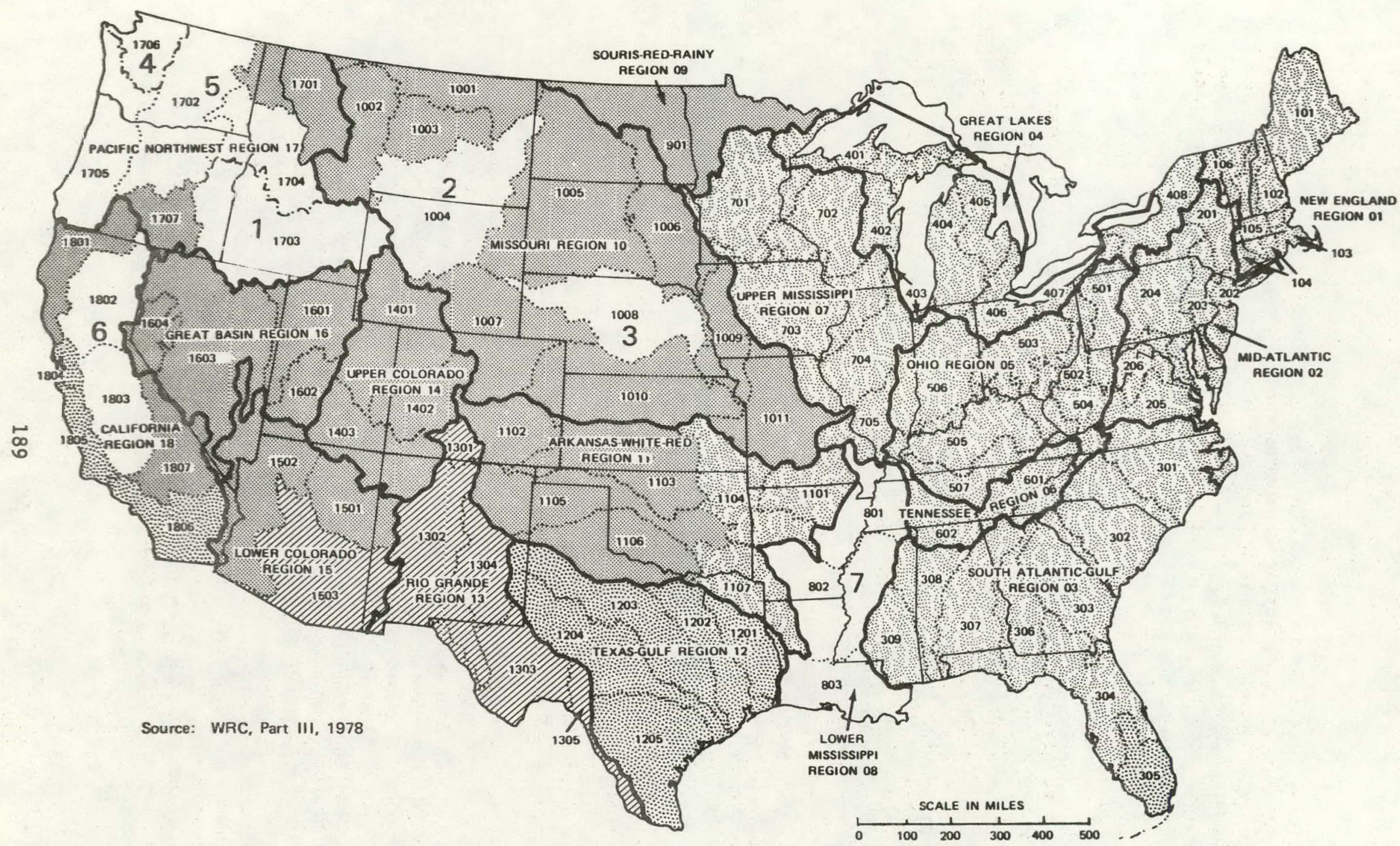

FIGURE A-1. METHODOLOGY FOR DETERMINING INSTREAM FLOW REQUIREMENTS IN EACH SUBBASIN 
NOTES FOR FIGURE A-1

The patterns on the map show where each of the following methods were used to obtain instream flow requirements. Except for method $D$ below, the requirements are based on water flow data prepared for the Second National Water Assessment.

A. Monthly requirements are 50 percent chance monthly streamflows. Annual requirements are averages of monthly requirements.

B. Annual requirements are 50 percent chance annual streamflows. Monthly requirements are computed by multiplying the monthly 50 percent chance strcamflows by the factor required to make the average of the monthly requirements equal the annual requirements.

C. Monthly requirements are either 40,60 . or 100 percent of the estimated monthly natural flows depending on seasonal needs. Annual requirements are averages of monthly requirements. The estimated natural flows are obtained for this purpose by adding consumptive uses and exports to present average streamflows and subtracting imports and ground water mined.

D. Method $\mathrm{C}$ above was used except that flushing flows $(100 \%)$ were not included.

E. Methods for these locations are based on more detailed information available from the following references:

1. Bayha, Keith and Charles Koski (Editors), ANATOMY OF A RIVER: REPORT OF HELLS CANYON CONTROLLED FLOW STUDY TASK FORCE, Washington. 1974

2. RESERVATION OF WATER IN THE YELLOWSTONE RIVER BASIN, Montana Fish and Game Commission. Helena, Montana. 1976

3. PLATTE RIVER BASIN, NEBRASKA LEVEL B STUDY, Missouri River Basin Commission. Omaha, Nebraska. 1976

4. Puget Sound Task Force. PUGET SOUND AND ADJACENT WATERS. COMPREHENSIVE WATER RESOURCE STUDY. Pacific Northwest River Basins Commission, Vancouver, Washington. 1970

5. Columbia Basin Fishery Technical Committee September 1975 letter report to Division Engineer, North Pacific Division, Corps of Engineers from Fred Cleaver, Program Director, National Marine Fisheries Service, Portland, Oregon.

6. Personal communication with Ed Whitsell, California Fish and Game Department, Stockton, California and Robert Hayden, Fiș and Wildlife Service, Sacramerito, California. 1977

7. Interagency Ad Hoc Study Group. REPORT ON MISSISSIPPI RIVER FLOW REQUIREMENTS FOR ESTUARINE USE IN COASTAL LOUISIANA AND THE ATCHAFALAYA BASIN. Mississippi River Commission, Vicksburg, Mississippi, 1970. Requirements for ASR 801 and 802 are obtained from the requirements for ASR 803 using the ratio of streamflow from ASR 801 and 802 to the streamflow from ASR 803. 


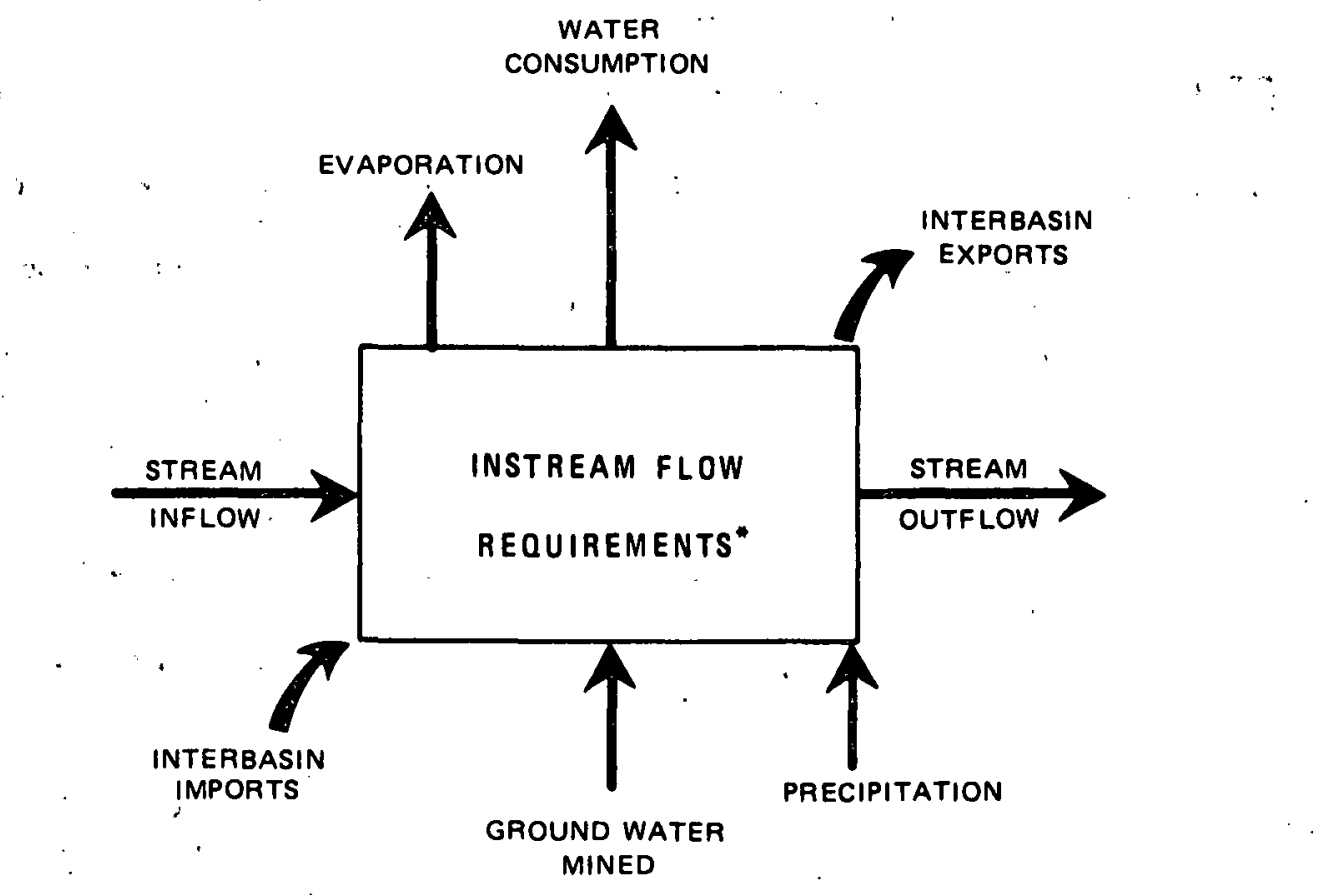

- Navigation, hydroelectric, treaties, and fish and wildlife instream flow requirements.

Source: WRC, 1978

FIGURE A.2: SCHEMATIC DIAGRAM OF WATER ANALYSIS MODEL 


\section{Stream Inflow}

Hydrologic and statistical analyses of more than 300 streamflow gauging stations were conducted to develop annual and monthly estimates of the amounts of water discharged by hydrologic unit. : The annual and monthly streamflow estimates were developed for the average condition and for five exceedance levels $(5 \%, 50 \%, 80 \%, 90 \%$, and $95 \%$ ). Furthermore, a linear trend analysis of the entire period of record. for each hydrologic unit was developed to examine the extent to which historical increases in offstream depletions may have caused decreased streamflow.

\section{Runoff}

Runoff is preclpitation millus, nafural evaporation (waler evaporated [rum (1) plant transpiration and (2) wet land surface areas). In some arid river basins, a deficit in runoff is possible (as shown by a negative number). In that case, the natural evaporation and water consumption by vegetation is greater than the rainfall. Under such conditions, vegetatiun makes up the deficit by consuming flows from upstream basins.

\section{Ground Water Mined}

Ground water mined is the quantity of water withdrawn that exceeds the existing natural and man-made recharge rates.

\section{Interbasin Imports and Exports}

Estimates of average annual and monthly net exporto are equal to gross exports minus gross imports. However, when the difference is negative, a value of zero is assumed to avoid negative total depletions.

\section{Evaporation}

Net evaporation losses from man-made reservoirs are l1mited to those from reservoirs with more than 5,000 acrc feel uf capactity (as of lyob) and from farm stock ponds (average size about 1 acre). In the eastern portion of the nation, where net evaporation losses were negative (1.e., runoff is greater than gross evaporation), the values wore set At $x=100$.

\section{Consumption}

Amounts of water required for consumption were developed for nine functional use categories on an annual and monthly basis for both average-and dry-year ( $20 \%$ exceedance) ralnfall conditions. The use cațegories are: 

a. Agriculture
b. Steam Electric
c. Manufacturing
d. Domestic
e. Commercial

\author{
f. Minerals \\ g. Public Lands \\ h. Fish Hatchery \\ i. Miscellaneous
}

\section{Instream Requirements}

These are requirements for uses that do not withdraw water from the stream, but rather depend either on a minimum amount of streamflow or on the depth of water passing a point. The instream uses considered in these analyses are navigation, recreation, hydropower generation, and fish and wildife. Water quality and existing treaties and compacts were also considered. In the analyses, the instream uses are not additive, as the offstream uses are; rather, the use that requires the greatest amount of water that must pass an aggregated subregion outflow point is the controlling use. In all cases, the fish and wildlife use was the largest and therefore controlled the analyses.

\section{Stream Outflow}

The lowest point at which the surface water leaves the basin is considered the point of outflow. It is the point for which current and future streamflow and depletions have been calculated. Under average year conditions, the amount of surface water.flowing out of an ASR is equal to the mean annual value. The amount of water flowing out of an ASR at the $80 \%$ exceedance level is the dry year condition. 


\section{THIS PAGE}

\section{WAS INTENTIONALLY \\ LEFT BLANK}




\section{Append IX B}

ESTIMATED EXCESS WATER SUPPLY AND REQUIREMENTS

BY SUBBASIN (DRY YEAR), 1985 AND 2000 


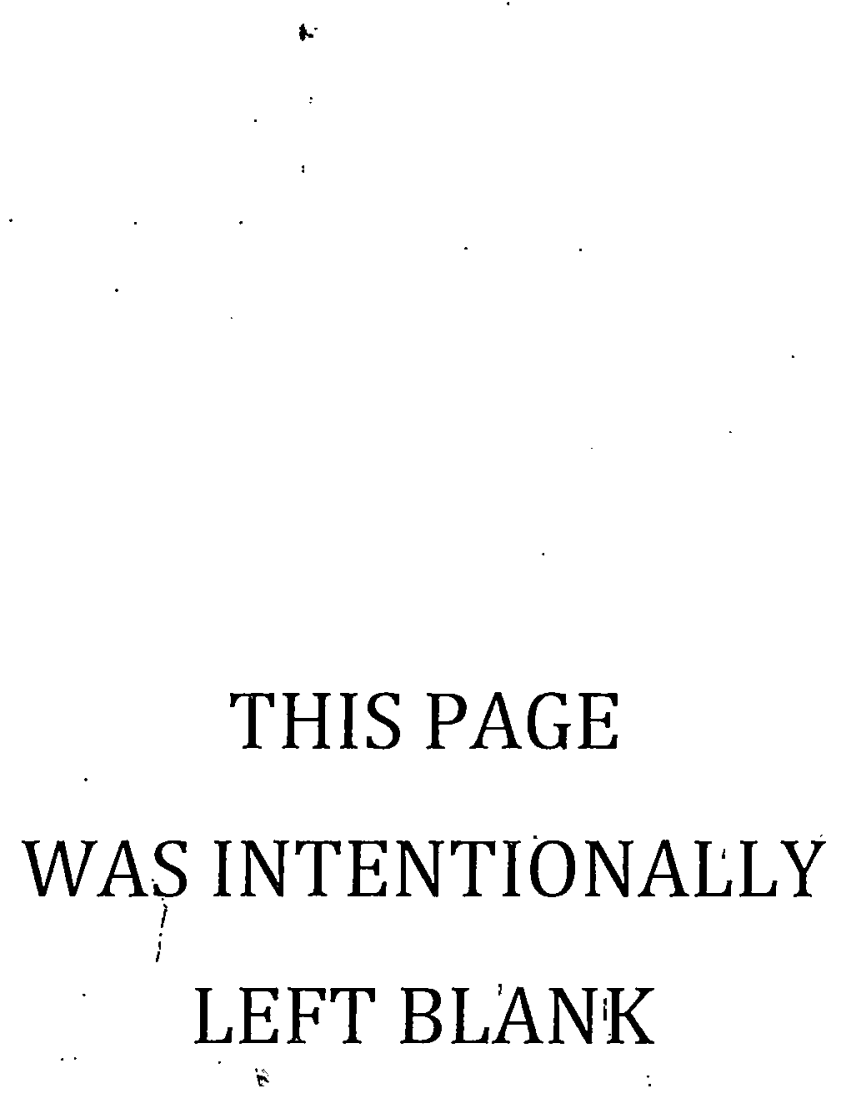

WAS INTENTIONALLY

LEFT BLANK 
Teble B-1

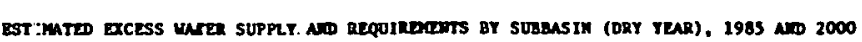

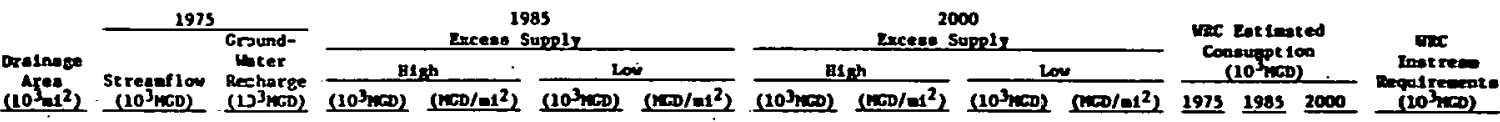

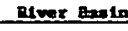

$\begin{array}{rrrrrrr}32.3 & 31.0 & 19.9 & 34.1 & 1.06 & 24.2 & 0.75 \\ 9.3 & 1.8 & 5.1 & 8.5 & 0.91 & 5.9 & 0.63 \\ 3.5 & 3.8 & 2.0 & 3.8 & 0.69 & 2.6 & 0.47 \\ 5.8 & 3.6 & 2.6 & 4.1 & 0.71 & 2.8 & 0.48 \\ 11.4 & 9.8 & 6.6 & 10.8 & .0 .95 & 7.5 & 0.66 \\ \frac{1.6}{71.9} & \frac{6.7}{62.7} & \frac{4.6}{10.8} & \frac{1.5}{68.8} & 0.99 & \frac{5.2}{48.2} & 0.68 \\ & & & & & & 0.67\end{array}$

\begin{tabular}{rr}
33.9 & 1.95 \\
8.5 & 0.91 \\
3.6 & 0.69 \\
6.0 & 0.69 \\
10.5 & 0.92 \\
\hline 1.5 & 0.99 \\
\hline 68.2 & 0.95
\end{tabular}

\begin{tabular}{rrrrrr}
24.0 & 0.74 & 0.09 & 0.14 & 0.26 & 33.35 \\
3.9 & 0.63 & 0.04 & 0.04 & 0.05 & 6.01 \\
2.6 & 0.47 & 0.14 & 0.19 & 0.26 & 6.00 \\
2.8 & 0.40 & 0.06 & 0.11 & 0.16 & 6.22 \\
7.2 & 0.63 & 0.12 & 0.16 & 0.31 & 10.90 \\
5.2 & 0.68 & 0.02 & 0.03 & 0.06 & 7.64 \\
\hline 4.7 & 0.66 & 0.49 & 0.65 & 1.07 & 69.09
\end{tabular}

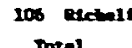

mor-artame

201 oner

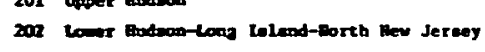
203 Delemers

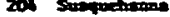

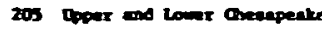

200 rocences

Someth Atlumt te-colf

301 vosnote-cape reax

302 De Dootedieto

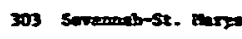

304 Sr. Jotmo-s in

306 Apelochicolo

307 Alabere-cosoctentanteboo

300 tobll-tombleber

309 Peocaspola-pear1

Toten

\begin{tabular}{|c|c|c|c|c|c|c|c|c|c|c|c|c|c|c|}
\hline 12.7 & 9.2 & 3.5 & 1.2 & 0.57 & 3.9 & 0.31 & 1.0 & 0.55 & 3.7 & 0.29 & 0.13 & 0.16 & 0.28 & 11.01 \\
\hline 19.1 & 11.4 & 1.8 & 6.2 & 0.32 & 2.0 & 0.10 & 5.9 & 0.31 & 1.7 & 0.09 & 0.50 & 0.60 & 0.76 & 13.87 \\
\hline 15.7 & 12.2 & 8.1 & 13.2 & 0.86 & 9.0 & 0.57 & 13.0 & 0.83 & 8.8 & 0.36 & 0.62 & 0.79 & 1.02 & 13.83 \\
\hline 27.6 & 20.0 & 13.4 & 22.6 & 0.82 & 16.2 & 0.59 & 22.4 & 0.81 & 16.0 & 0.38 & 0.26 & 0.35 & 0.54 & 21.39 \\
\hline 27.9 & 11.1 & 3.9 & 10.6 & 0.38 & 6.9 & 0.25 & 20.3 & 0.37 & 6.6 & 0.24 & 0.24 & 0.45 & 0.68 & 12: 33 \\
\hline 16.6 & 6.5 & 3.9 & 8.7 & 0.60 & 6.5 & 0.45 & 8.5 & 0.58 & 6.3 & 0.43 & $\underline{0.13}$ & $\underline{0.19}$ & $\underline{0.37}$ & 7.62 \\
\hline 117.6 & 70.4 & 38.6 & 68.5 & 0.58 & 44.5 & 0.38 & 67.1 & 0.57 & 63.1 & 0.37 & 1.89 & 2.54 & 3.63 & 60.20 \\
\hline 41.6 & 18.8 & 9.9 & 19.2 & 0.46 & 13.7 & 0.33 & 18.7 & 0.45 & 13.2 & 0.32 & 0.35 & 0.57 & 1.01 & 10.55 \\
\hline 42.0 & 19.6 & 11.0 & 19.0 & 0.45 & 12.2 & 0.29 & 18.4 & 0.46 & 11.6 & 0.28 & 0.30 & 0.59 & 1.19 & 22.50 \\
\hline 36.8 & 17.5 & 9.9 & 17.6 & 0.47 & 11.5 & 0.31 & 17.1 & 0.46 & 11.2 & 0.30 & 0.19 & 0.63 & 0.76 & 19.4) \\
\hline 36.0 & 10.5 & 7.6 & 20.1 & 0.29 & 5.6 & 0.16 & 9.7 & 0.28 & 3.2 & 0.15 & 1.34 & 1.69 & 2.07 & 15.0 \\
\hline 18.0 & 4.1 & 3.4 & 3.8 & 0.21 & 1.8 & 0.07 & 3.1 & 0.17 & 1.1 & 0.06 & 2.75 & 3.16 & 3.78 & 6.55 \\
\hline 26.1 & 16.6 & 8.4 & 15.3 & 0.63 & 9.6 & 0.40 & 15.0 & 0.62 & 9.3 & 0.39 & 0.25 & 0.39 & 0.69 & 19.03 \\
\hline 37.5 & 31.7 & 16.0 & 29.6 & 0.19 & 18.9 & 0.50 & 29.1 & 0.78 & 10.4 & 0.49 & 0.11 & 0.36 & 0.88 & 35.81 \\
\hline 21.9 & 32.1 & 16.0 & 29.9 & 1.37 & 19.1 & 0.87 & 29.8 & 1.36 & 19.0 & 0.87 & 0.20 & 0.31 & 0.44 & 36.11 \\
\hline 20.6 & 13.2 & 7.6 & 13.0 & 0.63 & 8.3 & 0.40 & 13.0 & 0.63 & 8.3 & 0.40 & $\underline{0.14}$ & $\underline{0.20}$ & 0.27 & 25.44 \\
\hline 277.3 & 164.1 & 89.8 & 157.3 & 0.37 & 200.7 & 0.36 & 153.9 & 0.55 & 97.3 & 0.35 & 5.61 & 7.70 & 11.09 & 288.66 \\
\hline
\end{tabular}


Table b-1 (Cont inued)

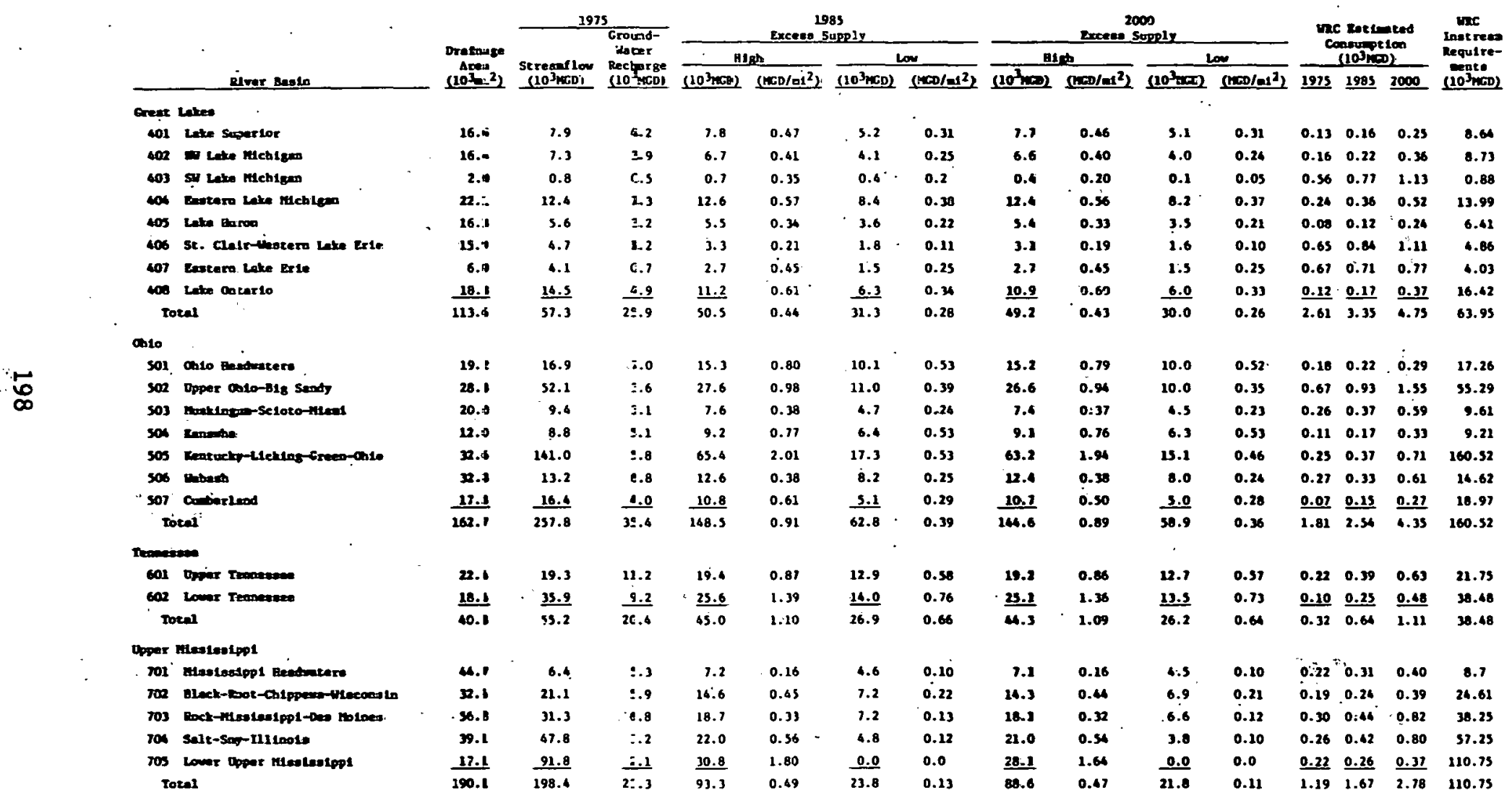


Table bil (Cont 1aued)

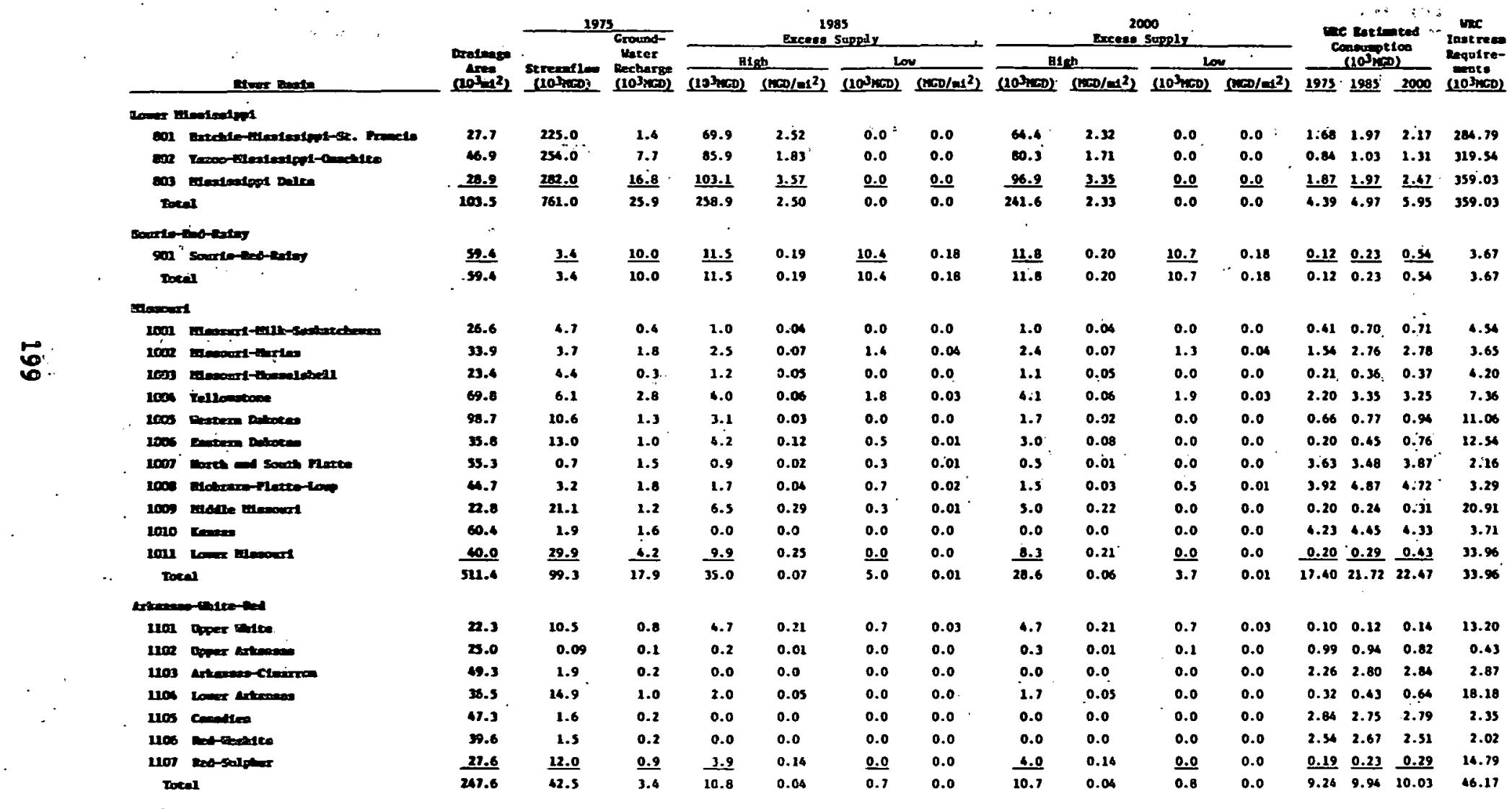




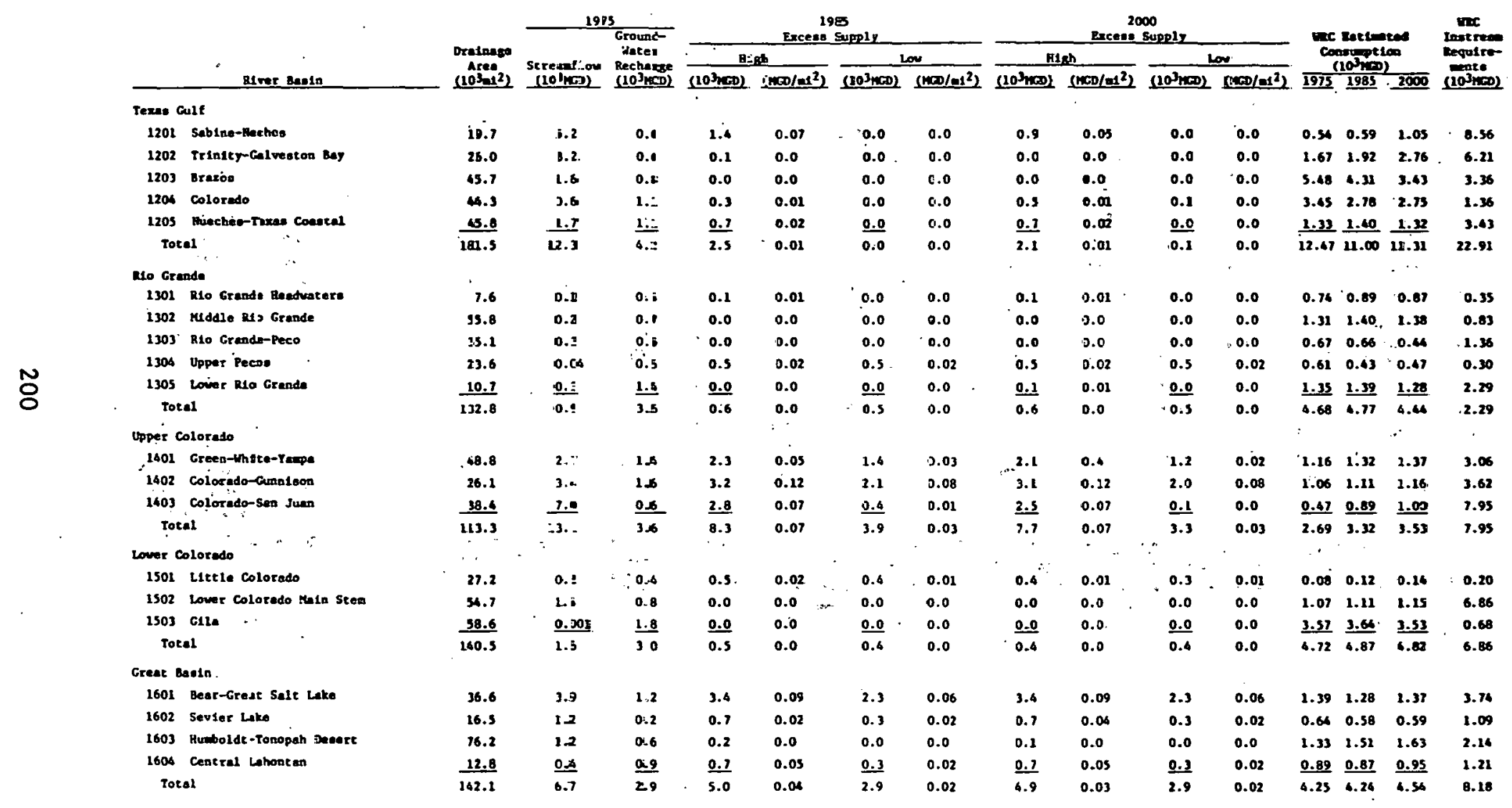




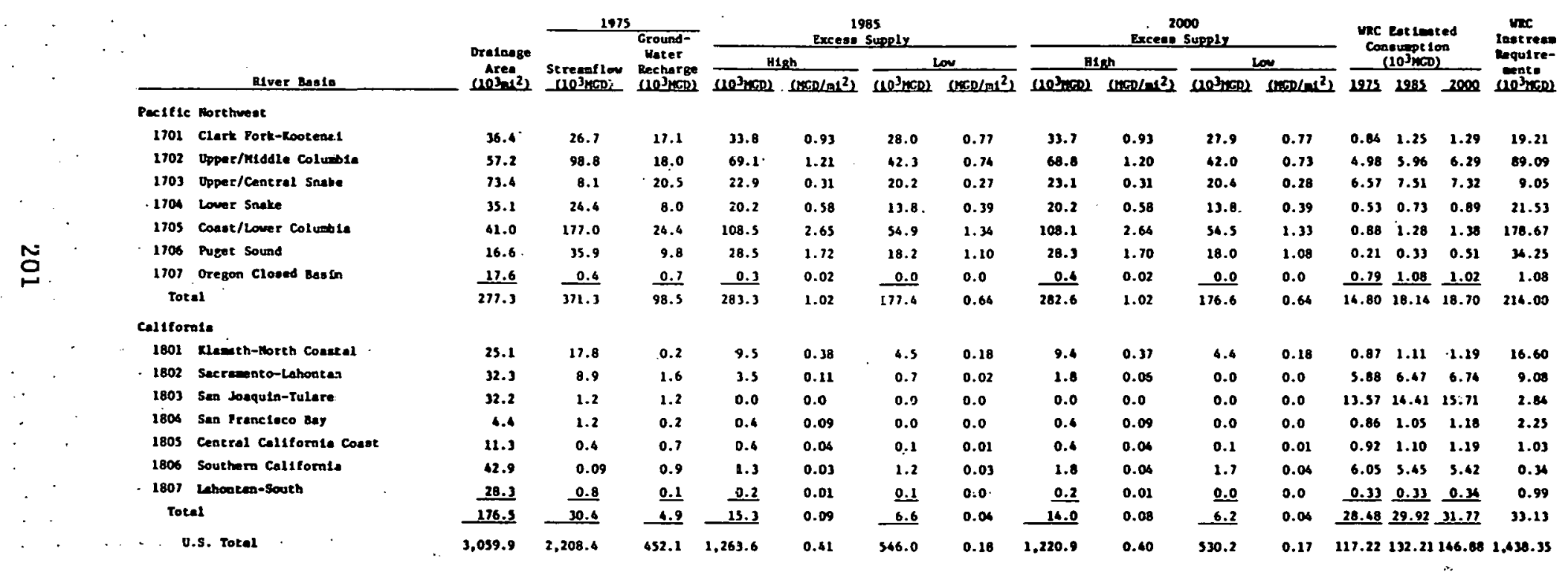


THIS PAGE

\section{WAS INTENTIONALLY \\ LEFT BLANK}


Appendix C

COMPUTATIONAL METHODOLOGIES 
THIS PAGE

\section{WAS INTENTIONALLY LEFT BLANK}




\section{Appendix C}

COMPUTATIONAL METHODOLOGIES

\section{Net Returns from Conventional Agriculture}

To quantify the profitability of conventional agriculture, average net returns were developed for the various land-use types considered in this study. This was accomplished in two steps. Individual net returns were first calculated for the major agricultural commodities produced within each land-use type. An average net return was next determined for each land-use type by weighting the net returns of the appropriate commodities in proportion to the amount of land devoted to each commodity. In this manner, average net returns were computed as a function of four parameters:

- Land-use type (17 were considered)

- Subbasin subregion (71 were considered)

- Land class (4 were considered)

- Time frame (1985 and 2000). used.

The remainder of this appendix describes more fully the methodology

\section{Commodity Net Returns}

The annual net return of an individual commodity can be simply defined in the following manner:

$$
N R=Y \times P-C,
$$

where,

$$
\begin{aligned}
\mathrm{NR}= & \text { net return, in dollars per acre } \\
\mathrm{Y}= & \text { yield of the commodity, in production units per acre } \\
& (\mathrm{e} \cdot \mathrm{g}, \mathrm{b} \text { bushels, pounds, tons) } \\
\mathrm{P}= & \text { selling price of the commodity, in dollars per } \\
& \text { production unit } \\
\mathrm{C}= & \text { cost of production, in dollars per acre. }
\end{aligned}
$$

To perform this analysis, yields for each commodity were required as a function of subbasin, time frame, and land class. Yleld data were 
available from USDA as a function of the first two of these parameters. In that these were average values over all land classes, however, it was necessary to disaggregate them into the four land-class types considered in this study. To accomplish this, yield index data published by Iowa State University were used. For each subbasin, this information indicated the yield of every commodity available from each land subclass. " The yield index data are tabulated as a fraction of the yield available from the first land subclass. Another necessary set of inputs was the acreage cultivated in each land subclass; as described previously in the discussion of land inventory, this information was obtained from the U.S. Soil Conservation Service.

With this information, the yield for the first land subclass can be approximated as follows:

$$
Y_{1}=Y_{\text {average }} \frac{\sum_{i=1}^{13} A_{i}}{\sum_{i=1}^{13}\left(A_{i}\right) \times\left(I_{i}\right)} \text {, }
$$

where,

$$
\begin{aligned}
& \mathrm{Y}_{1} \quad=\text { the yield for land subclass } 1 \\
& \mathrm{Y}_{\text {average }}=\text { the average yleld, over land subclasses (or } \\
& \text { clasges) obtained from the UEDA } \\
& A_{1}=\text { the acreage in land subclass } i \\
& \text { I = the yleld index for land subclass } 1 \text {. }
\end{aligned}
$$

\footnotetext{
*The four land classes considered in this study can be further subdivided Into thirteen land subclasses. The first land subclass corresponds exactly to the first land class. However, under each of the land classes two through four, four land subclasses are defined according to the factor that limits the usefulness of the land. The four limiting factors are cllinate, eroston, soll, and wetness. The following tabulation summarizes the relationship of these land classes and subclasses:
}

$$
\begin{array}{llccc}
\text { Land class } & 1 & 2 & 3 & 4 \\
\text { Land subclass } & 1 & \sqrt{2 C, 2 E, 2 S, 2 W} & \sqrt{3 C, 3 E, 3 S, 3 W} & 4 C, 4 E, 4 S, 4 W
\end{array}
$$

where:

$$
\begin{array}{ll}
\mathrm{C}=\text { climate } & \mathrm{S}=\text { soll } \\
\mathrm{E}=\text { erosion } & \mathrm{W}=\text { wetness }
\end{array}
$$


The ylelds for Individual land classes can then be found by use of the following formulae:

$$
\begin{aligned}
& Y_{\text {land class } 1}=\cdot Y_{1} \\
& Y_{\text {land class } N}=\sum_{1=K}^{K+3}\left(A_{1}\right) \times\left(Y_{1}\right) . \\
& \sum_{i=\mathrm{K}}^{\mathrm{K}+3} \mathrm{~A}_{1}
\end{aligned}
$$

where;

$$
\begin{aligned}
& K=2 \text { for } N=2 \\
& K=6 \text { for } N=3 \\
& K=10 \text { for } N=4
\end{aligned}
$$

As noted in Equation (1), price and cost of production data are also required in computing net returns. Since the derivations of these parameters were discussed previously in this report, they will not be discussed here.

The methodology outlined above was used in determining individual net returns for all of the commodities considered in this study except for forest products. Net return calculations for conventional forestry were handled according to the methodology described in the main text.

\section{Determination of Average Net Returns for Each Land-Use Type}

As noted above, the individual commodity net returns were combined to obtain weighted average net returns for each land-use type. The first step in this analysis was to group the various commodities according to their corresponding land-use type. The individual net returns within each group of commodities were then weighted by factors called "acreage fractions." These are defined as the proportions of the land area within a particular land-use type that are devoted to individual commodities. These data were derived for each subbasin from information published by USDA and supported by data from state and county agricultural extension services.

In analytical terms, the methodology used in determining the average net return for a particular land-use type (L), which incorporates $M$ commodities, can be described as follows:

$$
\text { average } \mathrm{NR}_{\mathrm{L}}=\sum_{i=1}^{\mathrm{M}}\left(\mathrm{AF_{1 }}\right) \times\left(\mathrm{NR}_{i}\right) \text {, }
$$


where,

$$
\begin{aligned}
\mathrm{AF}_{i}= & \text { the acreage fraction of commodity } i \text { (i.e., the area } \\
& \text { devoted to commodity } 1 \text { divided by the area within } \\
& \text { land use type } \mathrm{L} \text { ) } \\
\mathrm{NR}_{1}= & \text { the individual net return for commodity } 1 .
\end{aligned}
$$

The net returns from a number of land-use types were assumed to be zero for the purpose of this analysis. Those considered to be in this category include: summer fallow, conservation use, idle cropland, open land formerly cropped, ungrazed noncommercial forest land, and land in the "other" categories.

\section{Net Returns from Biomass Production}

The profitability of biomass production was quantified in a manner consistent with the analysis of conventional agriculture described above. Average net returns were computed as a function of subbasin, land class, and time, for each of 13 biomass production options considered in this study.

The various biomass operations can be divided into three basic classifications. The first is the food (fiber)/fuel combination that uses the food (or fiber) component of a commodity in the conventional manner and any available residues as biomass feedstocks. The second category is a fuel-only enterprise that uses the entire plant as an entery source. The third category consists of energy farms that raise specialty crops, such as sweet sorghum, kenaf, and trees (short-rotation hardwoods).

For each of these categories, average net returns were computed by using a methodology generally similar to that used in the conventional agricultural analysis. This first calculated net returns for each of the various commodities considered. These individual net returns were then weighted in proportion to the amount of land devoted to each commodity, resulting in an average net return for each of the 13 biomass options.

\section{Commod1ty Ner Returns}

Fuel-only--Because the biomass options within this category use the entire plant for energy purposes, the appropriate net return for a particular commodity is given by the following formula:

\section{NR - Biomass Pricc $\times$ Total Plant Yield - Assoclated Costs.}

The first parameter on the right side of the equation is the dollar price that a farmer could expect to recelve for a dry ton of biomass. The remalning two parameters can be defined in the following manner: 
Total Plant Yield $=Y \times B \times[D W F+D W R \times R]$

Associated Costs $=$ Total Plant Yield $\times[0+T]+C_{p}$,

where,

$\mathrm{Y}=$ yield of the food (fiber) component of the plant as calculated (in text) in production units (wet) per acre

$\mathrm{B}=$ factor that converts production units (wet) into wet tons (e.g., bushels to tons)

DWF = dry weight factor for the food (fiber) component of the plant, in dry tons per wet ton

DWR = dry weight factor for the residue component of the plant, in dry tons per wet ton.

$R$ = residue factor, defined as the wet tons of residue available per wet ton of food (fiber)

0 = opportunity cost associated with the use of the plant material as an energy source instead of as a fertilizer, in dollars per dry ton of biomass

$\mathrm{T}=$ transportation cost, in dollars per dry ton of biomass

$\mathrm{C}_{\mathrm{p}}=$ production cost, in dollars per acre.

The net return can therefore be expressed as:

$N R=[$ Biomass Price $-0-T] \times Y \times B \times[D W F+D W R \times R]-C_{p}$.

Whole-tree chipping, the fuel-only equivalent for forest products, was handled somewhat differently. Net returns were defined as follows:

$$
\mathrm{NR}=[\text { Biomass Price }-\mathrm{TC}] \times \mathrm{Y} \text {, }
$$

where,

TC $=$ total cost associated with whole tree chipping, in dollars per dry ton of wood chips

$\mathrm{Y}=$ annual yield, in dry tons of wood chips per harvested acre per year.

Food (Fiber)/Fuel Combinations--The overall return from a food (fiber)/ fuel combination is composed of two parts. One is the food component calculated in the main text and described above. The second portion is the value that the agricultural residue represents as a biomass fuel or feedstock. Combining these two net return components results in, an overall net return defined as follows:

$$
N R=U \times[P+B \times R \times D W R \times \text { (Biomass Price }-C C-0-T)]-C,
$$


where,

$Y, B, R$, DWR, Biomass Price, 0 , and $T$ are as defined as

for the fuel-only category

$P=$ the price of the conventional commodity, in dollars per production unit

$\mathrm{CC}=$ the collection cost of the residue, in dollars per dry ton of residue

$\mathrm{C}=$ the conventional cost of production, in dollars per acre.

The forest-related activity that is analagous to the food (fiber)/ fuel combination is the use of the bole of the tree for cunventional purpoees and the remaining (residue) purliun as a blomass fucl. These net returns were defined as follows:

$$
\mathrm{NR}=\mathrm{NR}_{\text {conventional }}+\mathrm{F} \times[\text { Biomass Price }-\mathrm{PC}], \quad:
$$

where,

$$
\begin{aligned}
F= & \text { forest residue yield, in dry tons of residue per acre } \\
& P C= \\
& \text { processing cost for forest residues, in dollars per } \\
& \text { dry }
\end{aligned}
$$

\section{Energy Farms}

The net return estimates for growing special commodities on energy farms were determined by the following equation:

$$
N R=Y \times \text { Biomass Price - Associated Costs. }
$$

For the sweet sorghum and kenaf energy farms, the yields were determined as a function of land class as outlined above. Because yield index data were not available for these commodities, the 1ndex fur luin was chosen as the most suitable alternative. The yield values used fur silvacultural energy farms are on an annual basis; these define the weight of wood chips assumed to be available each year per acre.

\section{Determination of Average Net Returns for Blomass Optluns}

Many of the biomass options are based on only one agricultural commodity, as in the case of the sweet sorghum plantation. For these options, net returns were defined as the net return of the single commodity produced. For the other biomass options, however, the net returns of the various commodities grown were weighted to determine an average net return. As described in the discussion of net returns from conventional agriculture, the acreage devoted to each commodity was used as a weighting factor. 
Appendix D

RANKING RESULTS FOR 71 SUBBASINS

WITH EXCESS WATER SUPPLIES 
THIS PAGE

\section{WAS INTENTIONALLY LEFT BLANK}


table $0-1$

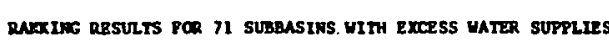

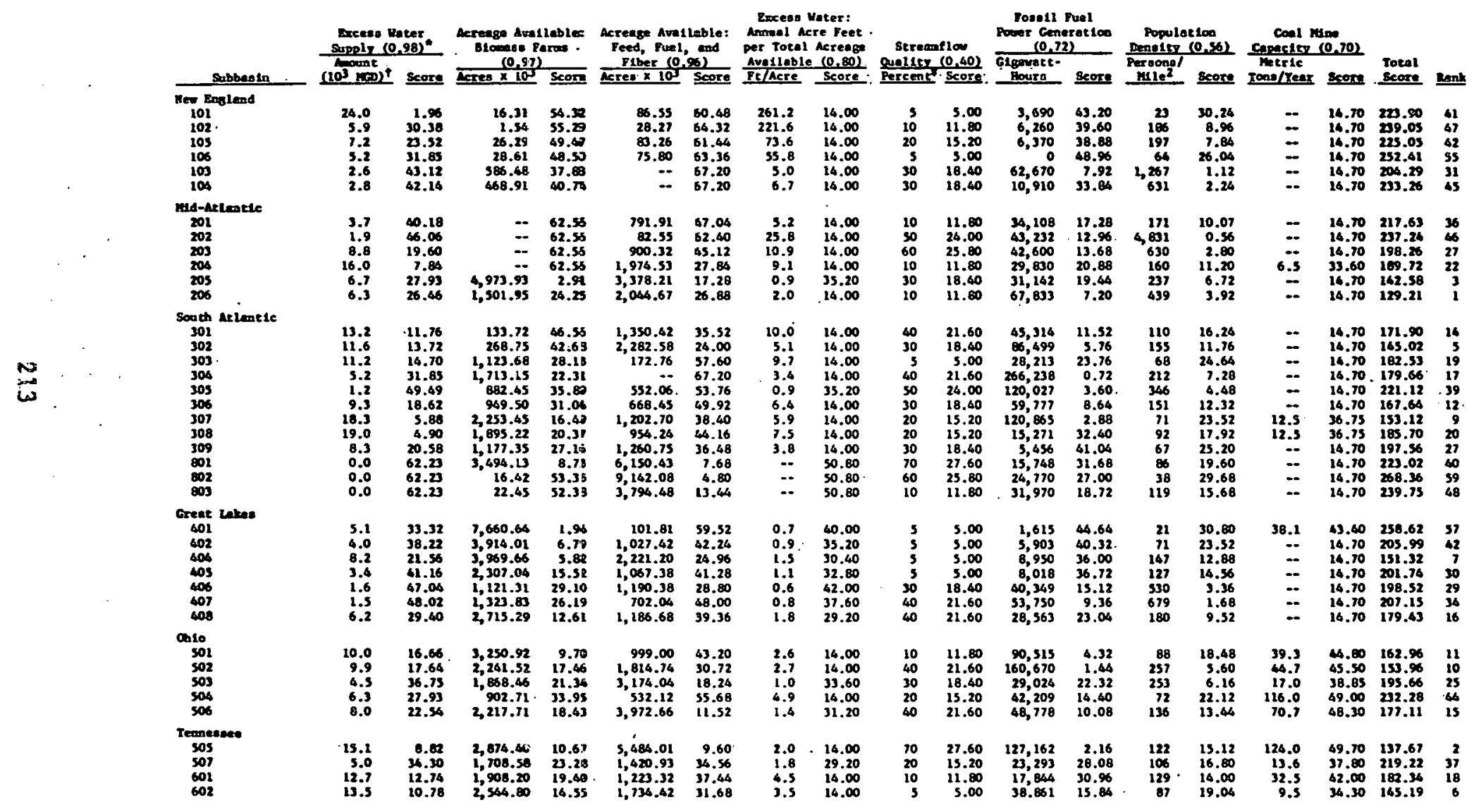




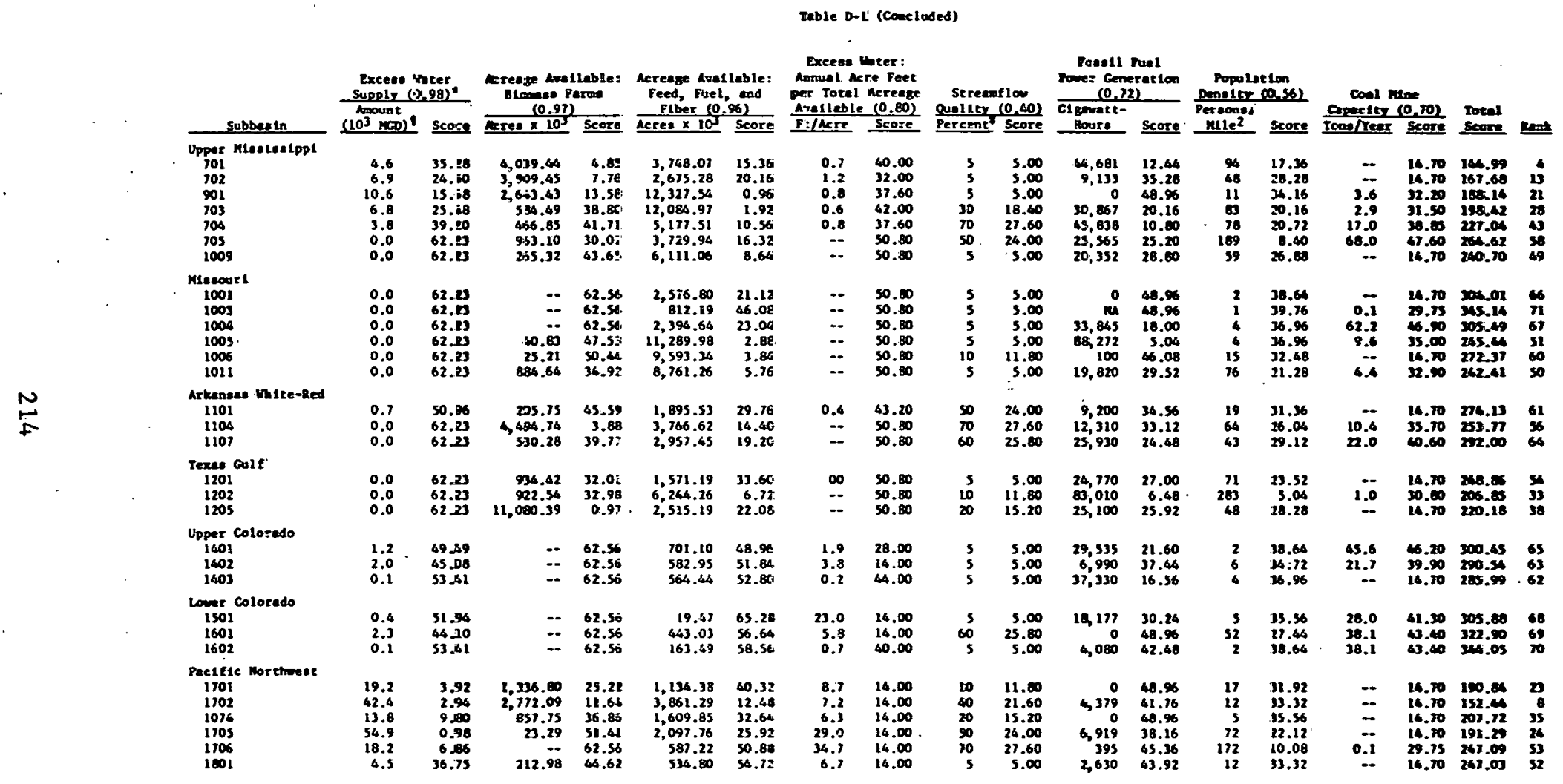

"rigures in parencheses refer to the wistres asolgred to the particular ind ceatar.

nod = alll loose of gallons per day.

that 10, the percentege of otreem thas do not meet vater qualtity itandards. 
Appendix E

RESULTS OF THE RANKING OF THE

TEN SELECTED SUBBASINS 


\section{THIS PAGE \\ WAS INTENTIONALLY \\ LEFT BLANK}


Table E-1

ECONOMIC INDICATOR--POTENTIAL ENERGY VALUE

\begin{tabular}{|c|c|c|c|c|c|c|c|}
\hline$\because$ & $\begin{array}{l}\text { BASIN } \\
\text { NO. }\end{array}$ & $\begin{array}{l}* * * * * * * * * * * * * * * \\
\text { SMALL GRAINS } \\
\text { I ISE+0BBTU/DT }\end{array}$ & $\begin{array}{l}\text { ****** PRODUCTION } \\
\text { SILVICULTURE } \\
.17 E+\text { OBBTU/DT }\end{array}$ & $\begin{array}{l}\text { SN IN } 2000 \text { CDRY } \\
\text { KENAF } \\
\text { 15E+OBBTU/DT }\end{array}$ & $\begin{array}{l}\text { TONS.) } * * * * * * * * * * \\
\text { SWEET SOROHUM } \\
\text {.15E+OBBTU/DT } 0 .\end{array}$ & $\begin{array}{c}* * * * * * * * * * \\
\text { OTHER } \\
\text { BTU/DT }\end{array}$ & $\begin{array}{c}\text { *** TOTAL *** } \\
\text { ENEROY VALUE } \\
\text { (BTU) }\end{array}$ \\
\hline$\underset{\sim}{\sim}$ & $\begin{array}{l}101 \\
206 \\
302 \\
304 \\
306 \\
404 \\
602 \\
701 \\
1101 \\
1702\end{array}$ & $\begin{array}{r}.923 E+05 \\
.428 E+07 \\
.400 E+07 \\
-0 . \\
.118 E+07 \\
.466 E+07 \\
.403 E+07 \\
.705 E+07 \\
.366 E+07 \\
.882 E+07\end{array}$ & $\begin{array}{l}.163 E+06 \\
.240 E+09 \\
.430 E+07 \\
.878 E+07 \\
.277 E+07 \\
.397 E+07 \\
.356 E+08 \\
.404 E+08 \\
.411 E+07 \\
.554 E+08\end{array}$ & $\begin{array}{l}-0 . \\
-0 . \\
-0 . \\
\vdots 140 E+08 \\
.932 E+07 \\
-0 . \\
-0 . \\
-0 . \\
-0 . \\
-0 .\end{array}$ & $\begin{array}{l}-0 . \\
-0 . \\
-0 . \\
-0 . \\
-0 . \\
-0 . \\
-0 . \\
-0 . \\
-0 . \\
-0 .\end{array}$ & $\begin{array}{l}-0 . \\
-0 . \\
-0 . \\
-0 . \\
-0 . \\
-0 . \\
-0 . \\
-0 . \\
-0 . \\
-0 .\end{array}$ & $\begin{array}{l}.416 E+13 \\
.415 E+16 \\
.133 E+15 \\
.359 E+15 \\
.204 E+15 \\
.137 E+15 \\
.666 E+15 \\
.792 E+15 \\
.125 E+15 \\
.107 E+16\end{array}$ \\
\hline
\end{tabular}


Table E-2

ECONOMII INDICATOR--AVEFAGE COST OF AGRICULTURAL LAND AND LAND BEING IRRIGATED

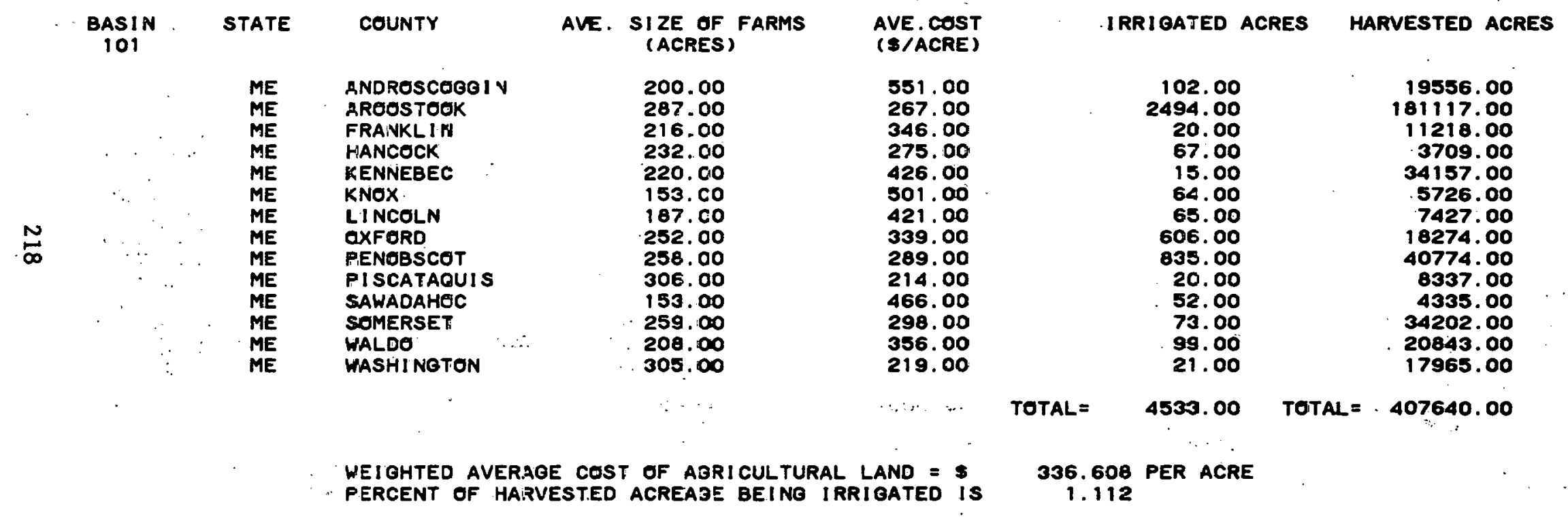


Table E-2 (Continued)

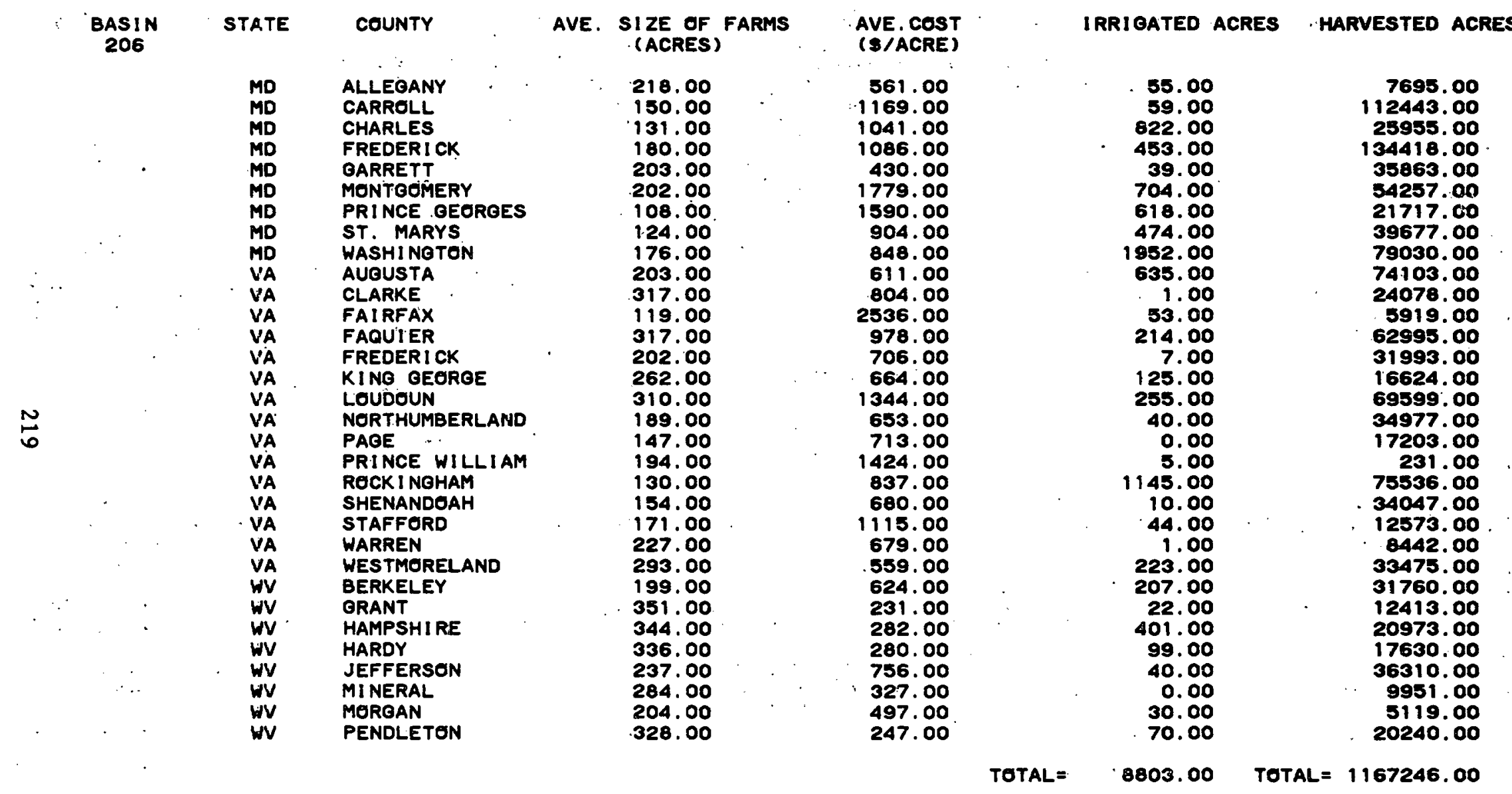


Table E-2 (Continued)

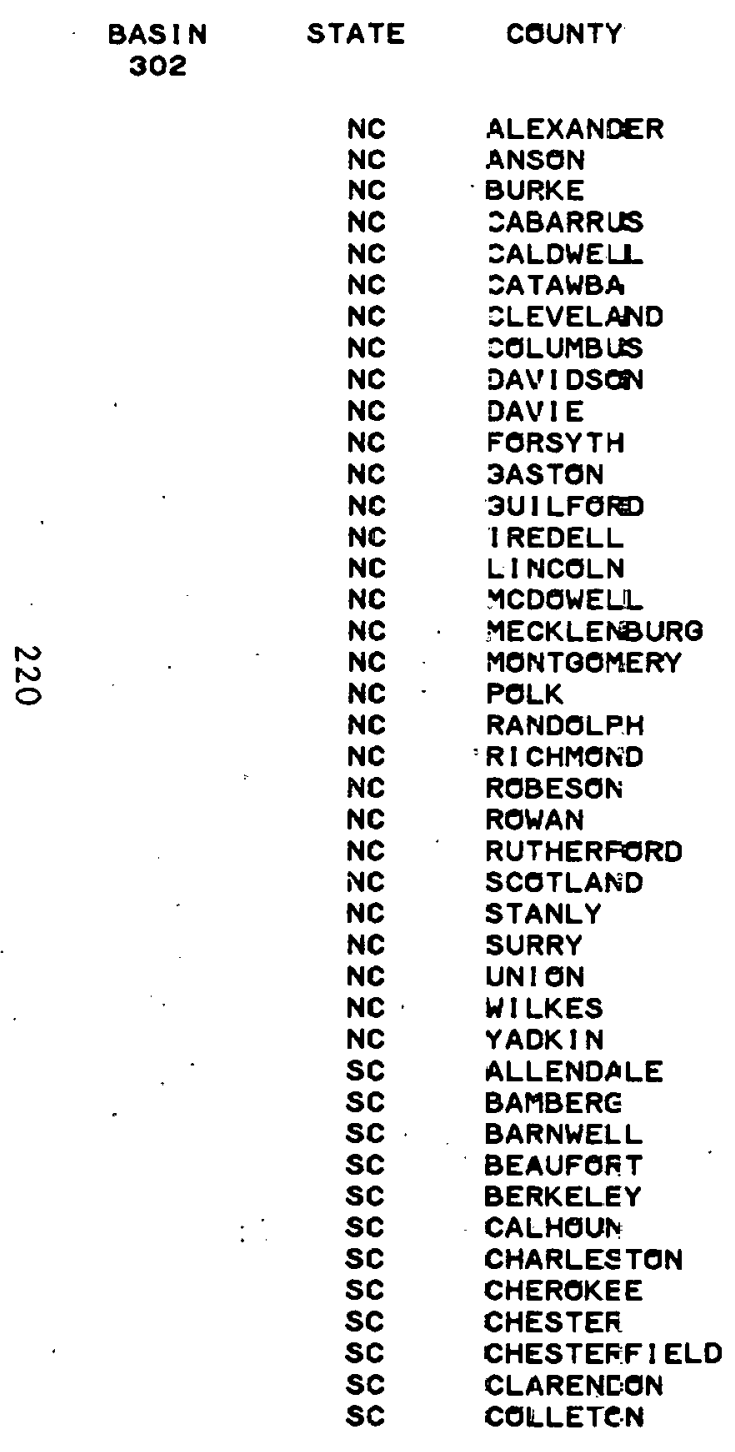

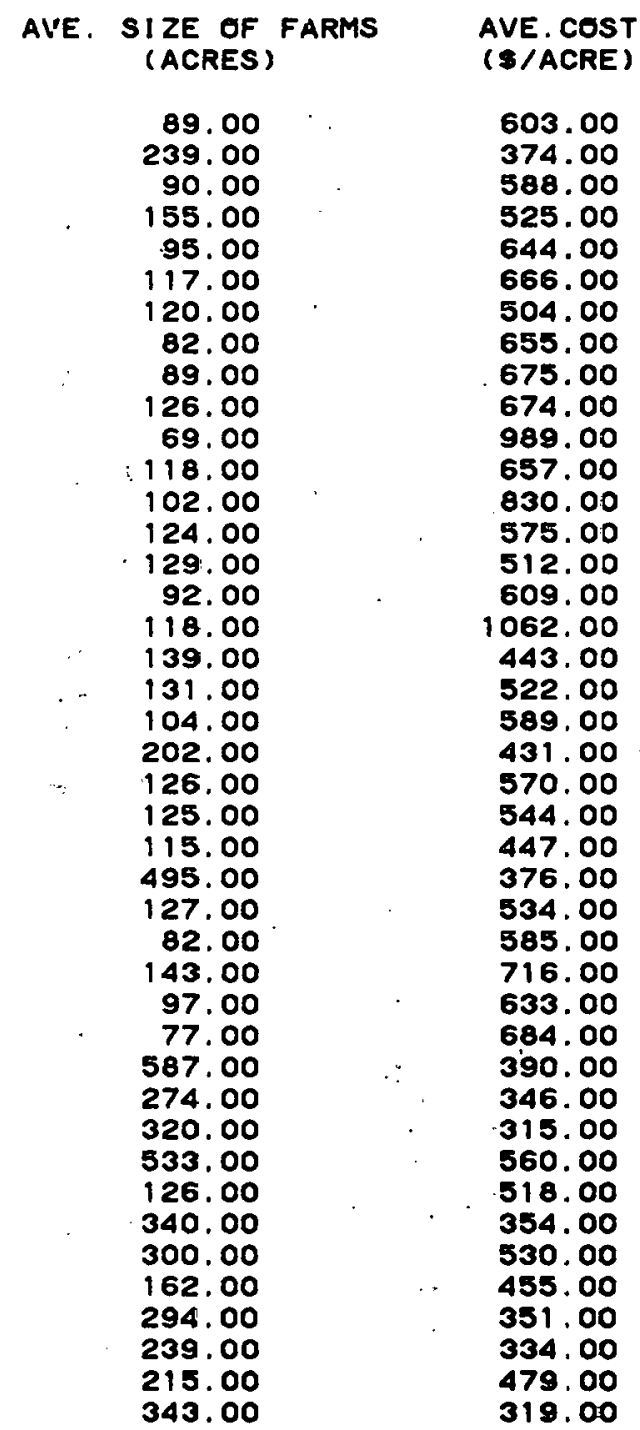

IRRIGATEO ACRES HARVESTED ACRES

$$
\begin{array}{r}
24.00 \\
9.00 \\
28.00 \\
17.00 \\
352.00 \\
20.00 \\
115.00 \\
285.00 \\
124.00 \\
41.00 \\
149.00 \\
13.00 \\
1233.00 \\
221.00 \\
107.00 \\
0.00 \\
123.00 \\
344.00 \\
12.00 \\
148.00 \\
886.00 \\
711.00 \\
167.00 \\
6.00 \\
371.00 \\
1.00 \\
660.00 \\
73.00 \\
6.00 \\
611.00 \\
598.00 \\
50.00 \\
16.00 \\
622.00 \\
162.00 \\
48.00 \\
144.00 \\
1377.00 \\
2.00 \\
353.00 \\
150.00 \\
44.00 \\
100
\end{array}
$$

$$
\begin{array}{r}
12827.00 \\
42192.00 \\
8549.00 \\
33003.00 \\
10734.00 \\
651.00 \\
45559.00 \\
86960.00 \\
33709.00 \\
21339.00 \\
17069.00 \\
16867.00 \\
42745.00 \\
48248.00 \\
30890.00 \\
4377.00 \\
13974.00 \\
11507.00 \\
5293.00 \\
50220.00 \\
22203.00 \\
171944.00 \\
46807.00 \\
17341.00 \\
45627.00 \\
53662.00 \\
35528.00 \\
106831.00 \\
19859.00 \\
45131.00 \\
74284.00 \\
61242.00 \\
59849.00 \\
16725.00 \\
25841.00 \\
69495.00 \\
22100.00 \\
15331.00 \\
16055.00 \\
71030.00 \\
105752.00 \\
53197.00 \\
\hline
\end{array}
$$


Table E-2 (Continued)

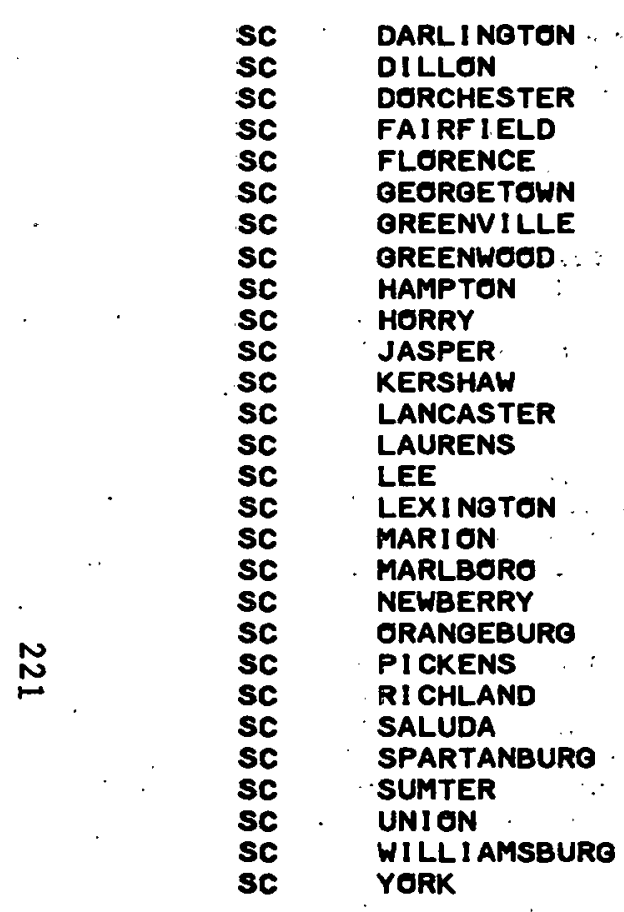

279.00
204.00
155.00
379.00
161.00
155.00
113.00
246.00
331.00
103.00
416.00
260.00
180.00
246.00
387.00
158.00
186.00
478.00
191.00
220.00
152.00
219.00
200.00
136.00
257.00
245.00
155.00
241.00

448.00
585.00
442.00
354.00
552.00
472.00
811.00
376.00
411.00
680.00
344.00
399.00
408.00
423.00
451.00
562.00
629.00
357.00
427.00
383.00
734.00
1017.00
412.00
57.00
463.00
385.00
464.00
504.00

277.00 473.00 25.00 0.00 243.00 87.00 132.00

41.00

0.00

962.00

75.00

1.00

0.00

10.00

98.00

(1.00

619.00

605.00

6.00

376.00

26.00

126.00

3.00

245.00

319.00

27.00

185.00

296.00

109948.00

71837.00

29622. 00

4246.00

119481.00

11006.00

21973.00

75733.00

8625

86255:00

19614.00

22704.00

12313.00

28112.00

105013.00

48306.00

50868.00

89348.

89348.00

29749.00

191394.00

6088.00

36200.00

34030.00

46650.00

103429.00

6424.00

98454.00

25614.00

TOTAL $=.16467 .00$

TOTAL $=3187731.00$

WEIGHTED AVERAQE COST OF AORICULTURAL LAND = PERCENT OF HARVESTED ACREAGE BEINO IRRIGATED IS

481.594 PER ACRE .517 
Table E-2 (Continued)

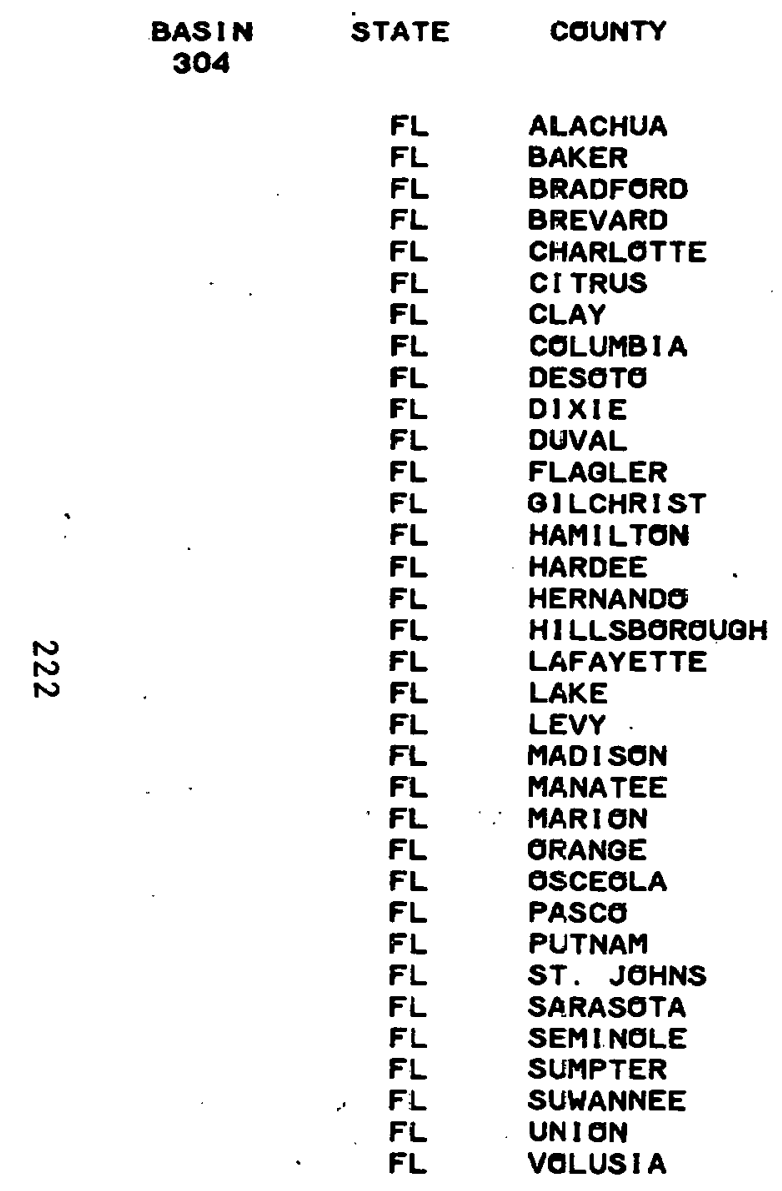

$\begin{array}{cr}\text { AVE. SIZE OF FARMS } & \text { AVE.COST } \\ \text { (ACRES) } & \text { (\$/ACRE) } \\ 299.00 & 704.00 \\ 204.00 & 548.00 \\ 158.00 & 636.00 \\ 555.00 & 452.00 \\ 675.00 & 415.00 \\ 209.00 & 468.00 \\ 674.00 & 366.00 \\ 240.00 & 587.00 \\ 414.00 & 684.00 \\ 1142.00 & 179.00 \\ 305.00 & 721.00 \\ 1113.00 & 291.00 \\ 287.00 & 551.00 \\ 297.00 & 493.00 \\ 316.00 & 735.00 \\ 226.00 & 1053.00 \\ 153.00 & 1179.00 \\ 255.00 & 511.00 \\ 213.00 & 1388.00 \\ 686.00 & 378.00 \\ 255.00 & 420.00 \\ 591.00 & 759.00 \\ 454.00 & 165.00 \\ 208.00 & 1743.00 \\ 2317.00 & 258.00 \\ 335.00 & 706.00 \\ 384.00 & 457.00 \\ 253.00 & 629.00 \\ 1056.00 & 415.00 \\ 157.00 & 997.00 \\ 326.00 & 542.00 \\ 217.00 & 613.00 \\ 292.00 & 489.00 \\ 225.00 & 685.00\end{array}$

\section{IRRIGATED ACRES HARVESTED ACRES}

$$
\begin{array}{r}
6413.00 \\
126.00 \\
142.00 \\
43925.00 \\
11364.00 \\
1054.00 \\
258.00 \\
1249.00 \\
48472.00 \\
4.00 \\
228.00 \\
4782.00 \\
890.00 \\
961.00 \\
39705.00 \\
1715.00 \\
26359.00 \\
1571.00 \\
59195.00 \\
3338.00 \\
1321.00 \\
29952.00 \\
11522.00 \\
37738.00 \\
12828.00 \\
12901.00 \\
4296.00 \\
17907.00 \\
12047.00 \\
4566.00 \\
6855.00 \\
6322.00 \\
444.00 \\
5561.00
\end{array}
$$


Table E-2 (Continued)

$\begin{array}{ll}\text { GA } & \text { BERRIEN } \\ \text { OA } & \text { BROOKS } \\ \text { OA } & \text { CLINCH } \\ \text { OA } & \text { COLQUITTE } \\ \text { OA } & \text { COOK } \\ \text { OA } & \text { ECHOLS } \\ \text { OA } & \text { IRWIN } \\ \text { OA } & \text { LANIER } \\ \text { OA } & \text { LOWNDES } \\ \text { OA } & \text { TIFT } \\ \text { OA } & \text { TURNER }\end{array}$

$$
\begin{aligned}
& 242.00 \\
& 336.00 \\
& 307.00 \\
& 236.00 \\
& 196.00 \\
& 162.00 \\
& 280.00 \\
& 275.00 \\
& 235.00 \\
& 254.00 \\
& 364.00
\end{aligned}
$$

482.00
438.00
231.00
493.00
573.00
316.00
489.00
374.00
397.00
616.00
519.00

1904.00

1484.00

10.00

3623.00

2074.00

115.00

1653.00

817.00

613.00

5262.00

1936.00

80741.00

2410.00

0487.00

98587.00

39393.00

$\mathbf{3 4 3 2} .00$

70061.00

11530.00

42346.00

519.00

55959.00

TOTAL $=435502.00$

51236.00

TOTAL= 1452716.00

WEIOHTED AVERAOE COST OF AQRICULTURAL LAND = $\$ \quad 487.157$ PER ACRE

PERCENT OF HARVESTED ACREAGE BEINO IRRIGATED IS

29.978 
Table E-2 (Contineud)

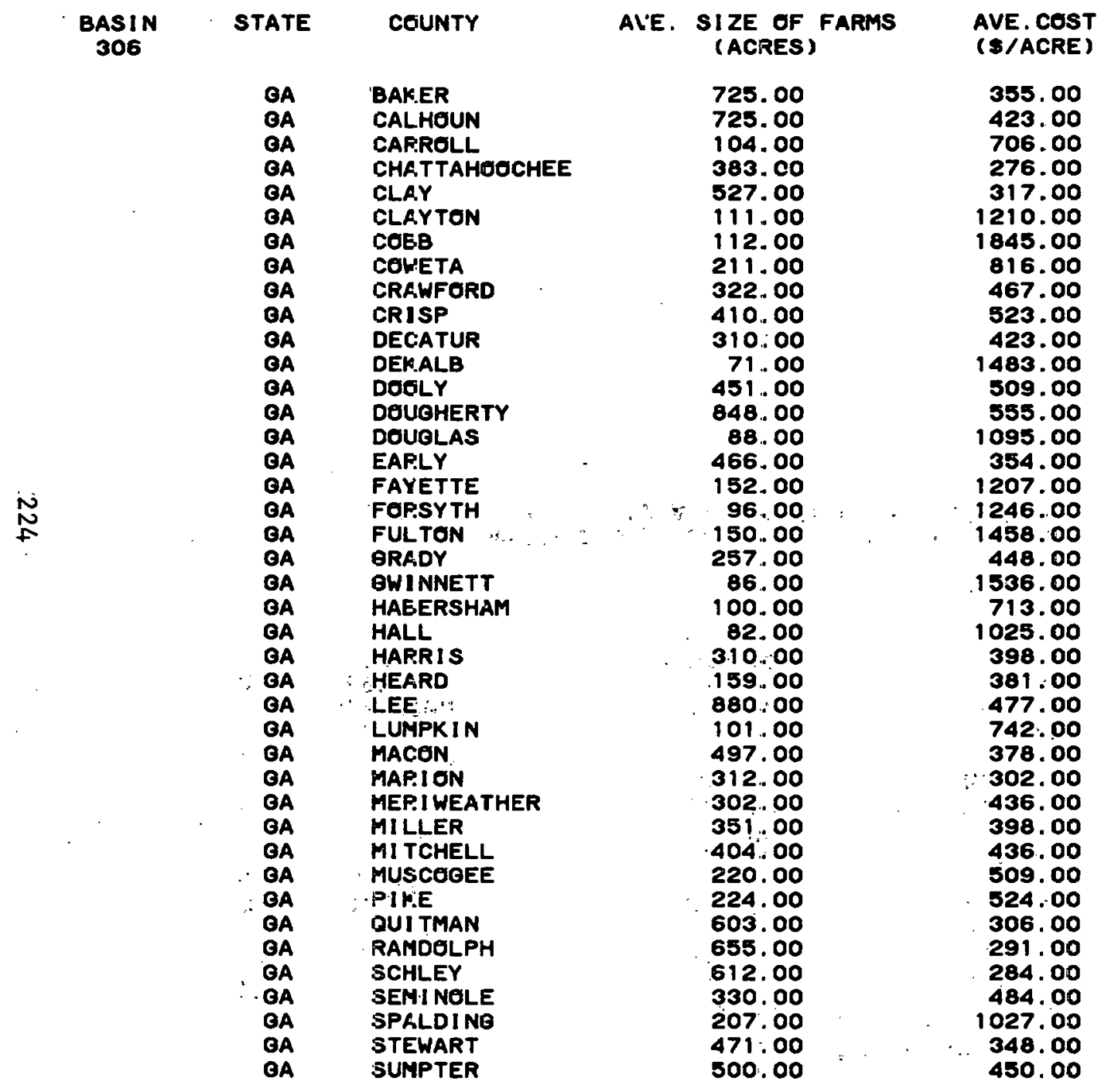

IRR: OATED ACRES HARVESTEO ACRES

\begin{tabular}{rr}
6012.00 & 41777.00 \\
2715.00 & 48132.00 \\
35.00 & 7801.00 \\
0.00 & 530.00 \\
4.00 & 24186.00 \\
0.00 & 1094.00 \\
93.00 & 2741.00 \\
32.00 & 9252.00 \\
9.00 & 16922.00 \\
1181.00 & 6467.00 \\
9575.00 & 66295.00 \\
16.00 & 751.00 \\
586.00 & 101868.00 \\
1610.00 & 34872.00 \\
3.00 & 895.00 \\
5362.00 & 94670.00 \\
75.00 & 4037.00 \\
15.00 & 4171.00 \\
49.00 & 6373.00 \\
1840.00 & 73516.00 \\
49.00 & 5137.00 \\
6.00 & 3491.00 \\
0.00 & 6142.00 \\
165.00 & 6396.00 \\
0.00 & 3600.00 \\
4260.00 & 60439.00 \\
21.00 & 71960.00 \\
865.00 & 74665.00 \\
0.00 & 12153.00 \\
6.00 & 15151.00 \\
13805.00 & 64382.00 \\
9352.00 & 102322.00 \\
0.00 & 591.00 \\
3.00 & 11130.00 \\
0.00 & 6013.00 \\
2084.00 & 50205.00 \\
0.00 & 12329.00 \\
9731.00 & 43836.00 \\
15.00 & 10166.00 \\
1286.00 & 19619.00 \\
1481.00 & 88887.00 \\
& \\
\hline &
\end{tabular}


Table E-2 (Continued)

\begin{tabular}{|c|c|c|c|c|c|}
\hline $\begin{array}{l}\text { OA } \\
\text { OA } \\
\text { OA } \\
\text { OA } \\
\text { OA } \\
\text { OA } \\
\text { BA } \\
\text { OA }\end{array}$ & $\begin{array}{l}\text { TALBOT } \\
\text { TAYLOR } \\
\text { TERRELL } \\
\text { THOMAS } \\
\text { TROUP } \\
\text { UPSON } \\
\text { HEBSTER } \\
\text { HHI TE. }\end{array}$ & $\begin{array}{l}369.00 \\
348.00 \\
646.00 \\
382.00 \\
214.00 \\
231.00 \\
495.00 \\
78.00\end{array}$ & $\begin{array}{l}271.00 \\
308.00 \\
440.00 \\
484.00 \\
445.00 \\
423.00 \\
345.00 \\
896.00\end{array}$ & $\begin{array}{r}0.00 \\
170.00 \\
410.00 \\
632.00 \\
51.00 \\
1.00 \\
350.00 \\
0.00\end{array}$ & $\begin{array}{r}3336.00 \\
24174.00 \\
72490.00 \\
71006.00 \\
5475.00 \\
4841.00 \\
20887.00 \\
2734.00\end{array}$ \\
\hline $\begin{array}{l}\text { OA } \\
\text { AL } \\
\text { AL } \\
\text { AL } \\
\text { AL } \\
\text { AL. } \\
\text { AL }\end{array}$ & $\begin{array}{l}\text { WORTH } \\
\text { BARBOUR } \\
\text { CHAMBERS } \\
\text { HENRY } \\
\text { HOUSTON } \\
\text { LEE: } \\
\text { RUSSELL }\end{array}$ & $\begin{array}{l}364.00 \\
374.00 \\
301.00 \\
292.00 \\
199.00 \\
252.00 \\
578.00\end{array}$ & $\begin{array}{l}506.00 \\
258.00 \\
251.00 \\
296.00 \\
391.00 \\
372.00 \\
306.00\end{array}$ & $\begin{array}{r}1363.00 \\
476.00 \\
24.00 \\
270.00 \\
2158.00 \\
37.00 \\
2.00\end{array}$ & $\begin{array}{r}106550.00 \\
48006.00 \\
11706.00 \\
62454.00 \\
110056.00 \\
15548.00 \\
26845.00\end{array}$ \\
\hline
\end{tabular}


Table E-2 (Continued)

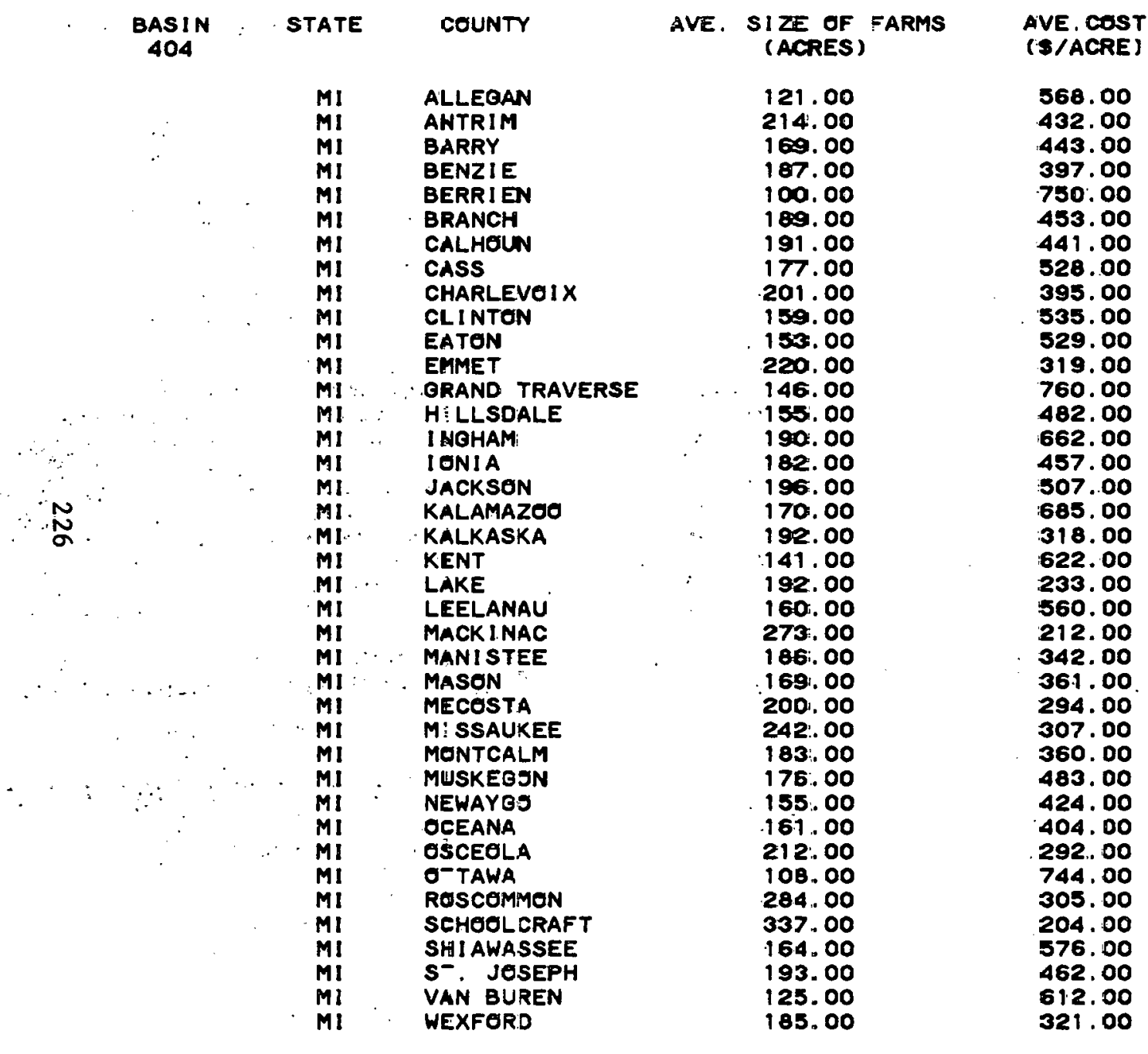

IRRIGATED ACRES HARVESTED ACRES
3620.00
665.00
494.00
150.00
7054.00
4060.00
1482.00
2795.00
5.00
433.00
429.00
212.00
586.00
384.00
1983.00
1262.00
769.00
769.00
271.00
3657.00
0.00
616.00
0.00
1588.00
343.00
3592.00
31.00
10824.00
3384.00
2687.00
020.00
922.00
123.00
4970.00
0.00
0.00
138.00
7540.00
11234.00
37.00
155774.00
19654.00
94348.00
7711.00
121558.00
15.4929 .00
151043.00
110956.00
10956.00
15623.00
172393.00
143512.00
14539.00
30420.00
166987.00
137695.00
153848.00
153848.00
26472:00
98121.00
4419.00
133154.00
6366.00
26788.00
8134.00
16906.00
43296.00
43296.00
54081.00
43399.00
128427.00
42928.00
59049.00
54136.00
54136.00
45140.00
103613.00
03613.00
1163.00
4567.00
163375.00
141328.00
113552.00
14481.00


Table E-2 (Continued)

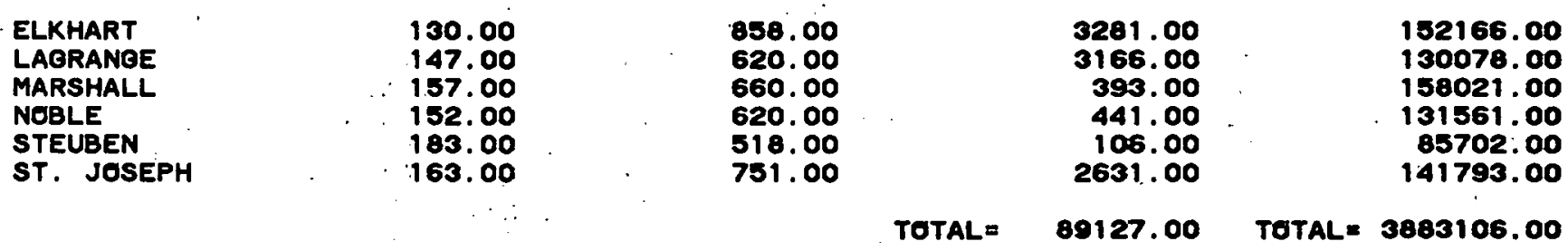

WEIOHTED AVERAOE COST OF. AGRI CULTURAL LAND $=\ldots . . .456 .096$ PER ACRE PERCENT OF HARVESTED ACREAGE BEINO IRRIOATED IS 2.295 
Table E-2 (Contı́nued)

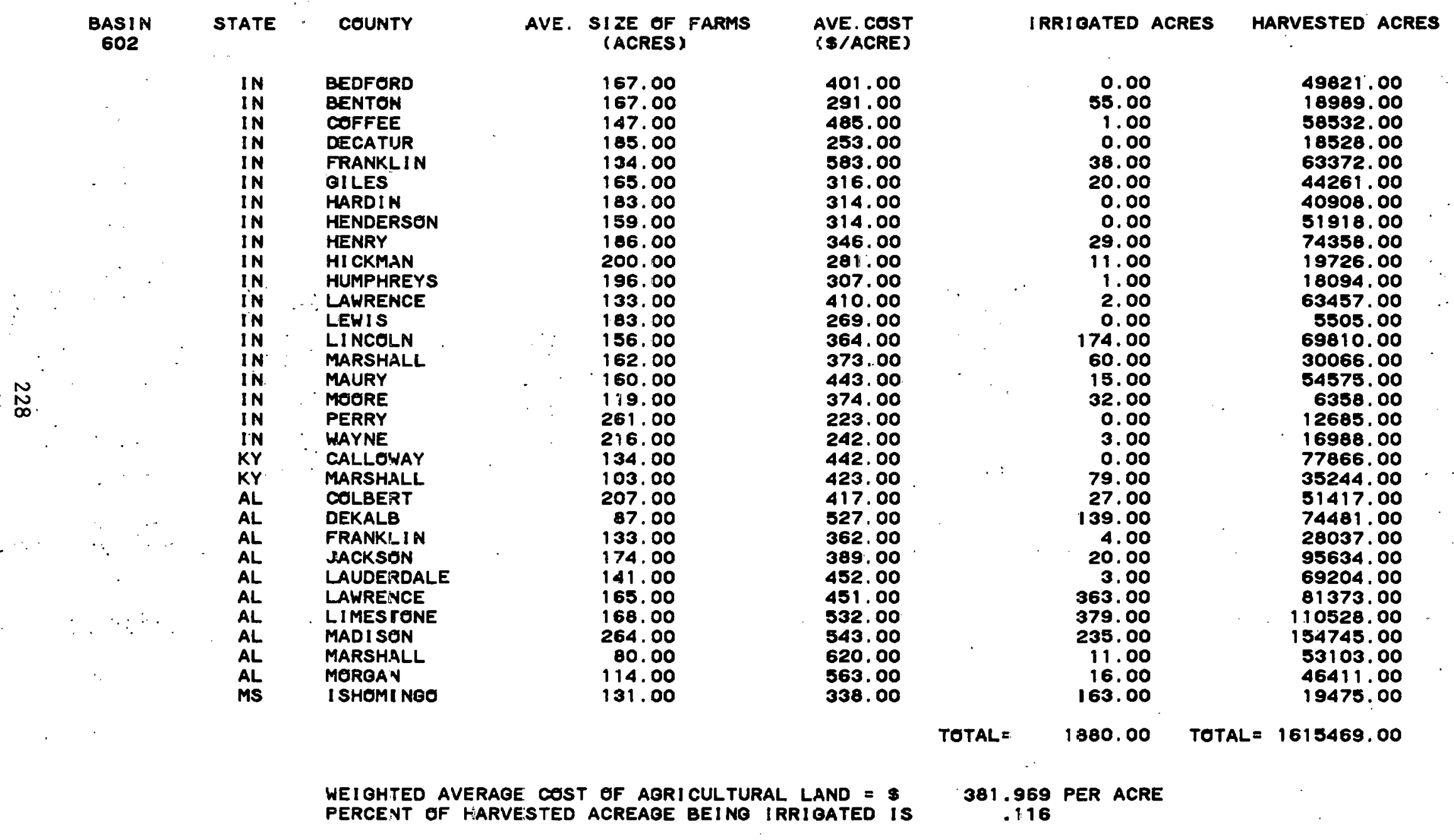


Table E-2 (Continued)

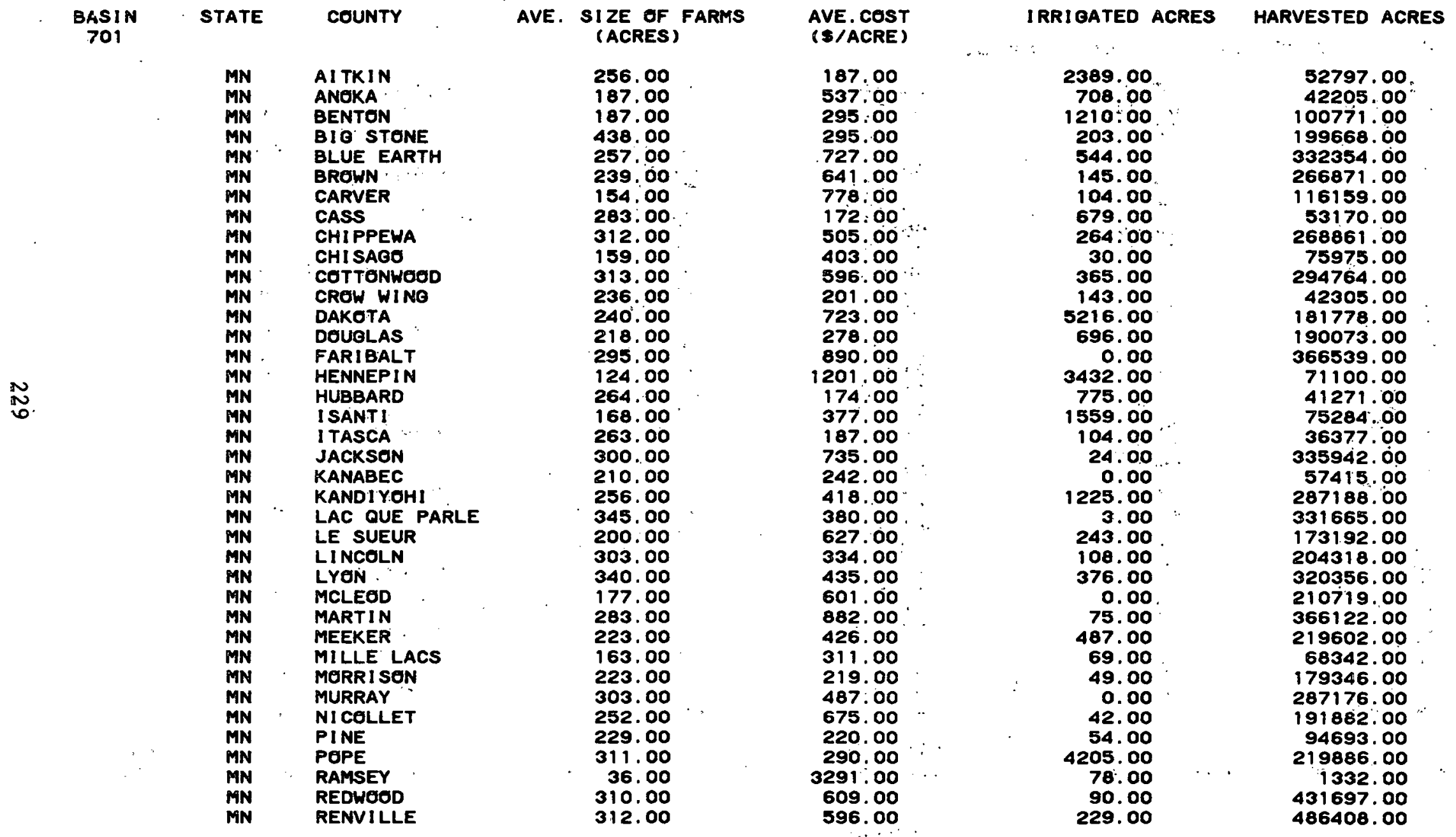


Table E-2 (Continued)

\begin{tabular}{|c|c|c|c|c|c|c|c|}
\hline & $\begin{array}{l}M N \\
M N \\
M N \\
M N \\
M N \\
M N \\
M N \\
M N \\
M N \\
M N \\
M N \\
M N \\
M N \\
M N \\
W I \\
W I \\
W I \\
W I \\
S D \\
S D\end{array}$ & $\begin{array}{l}\text { SCOTT } \\
\text { SHEREURNE } \\
\text { SIBLEY } \\
\text { STEARNS } \\
\text { STEVENS } \\
\text { SWIFT } \\
\text { TODD } \\
\text { HADENA } \\
\text { WASECA } \\
\text { HASHINGTON } \\
\text { WATOMWAN } \\
\text { WRIGHT } \\
\text { YELLOW MEDICINE } \\
\text { BURNETT } \\
\text { POLK } \\
\text { ST. CROIX } \\
\text { WASSBURN } \\
\text { ORANT } \\
\text { ROBERTS }\end{array}$ & $\begin{array}{l}158.00 \\
210.00 \\
222.00 \\
205.00 \\
418.00 \\
385.00 \\
203.00 \\
253.00 \\
246.00 \\
176.00 \\
270.00 \\
149.00 \\
323.00 \\
205.00 \\
186.00 \\
209.00 \\
268.00 \\
497.00 \\
508.00\end{array}$ & $\begin{array}{l}745.00 \\
397.00 \\
657.00 \\
320.00 \\
403.00 \\
361.00 \\
239.00 \\
191.00 \\
697.00 \\
940.00 \\
795.00 \\
590.00 \\
452.00 \\
257.00 \\
334.00 \\
469.00 \\
204.00 \\
215.00 \\
225.00\end{array}$ & & $\begin{array}{r}47.00 \\
10783.00 \\
0.00 \\
3603.00 \\
601.00 \\
3222.00 \\
4249.00 \\
1871.00 \\
1.00 \\
2023.00 \\
140.00 \\
1444.00 \\
86.00 \\
19.00 \\
78.00 \\
1140.00 \\
483.00 \\
204.00 \\
165.00\end{array}$ & $\begin{array}{r}102031.00 \\
73910.00 \\
262986.00 \\
414221.00 \\
260097.00 \\
314753.00 \\
199207.00 \\
66332.00 \\
197052.00 \\
76706.00 \\
216290.00 \\
194698.00 \\
368751.00 \\
38146.00 \\
172464.00 \\
217201.00 \\
34617.00 \\
263208.00 \\
436752.00\end{array}$ \\
\hline 菅 & & $\therefore$ & & & TOTAL $=$ & 56082.00 & TOTAL $=11185025.00$ \\
\hline & & $\begin{array}{l}\text { WEIGHTED AVERAC } \\
\text { PERCENT OF HARI }\end{array}$ & CREAQ̣E & $\begin{array}{l}D=\$ \\
\text { TED is }\end{array}$ & $\begin{array}{r}454.88 \\
.50\end{array}$ & PER ACRE & \\
\hline
\end{tabular}


Table E-2 (Continued)

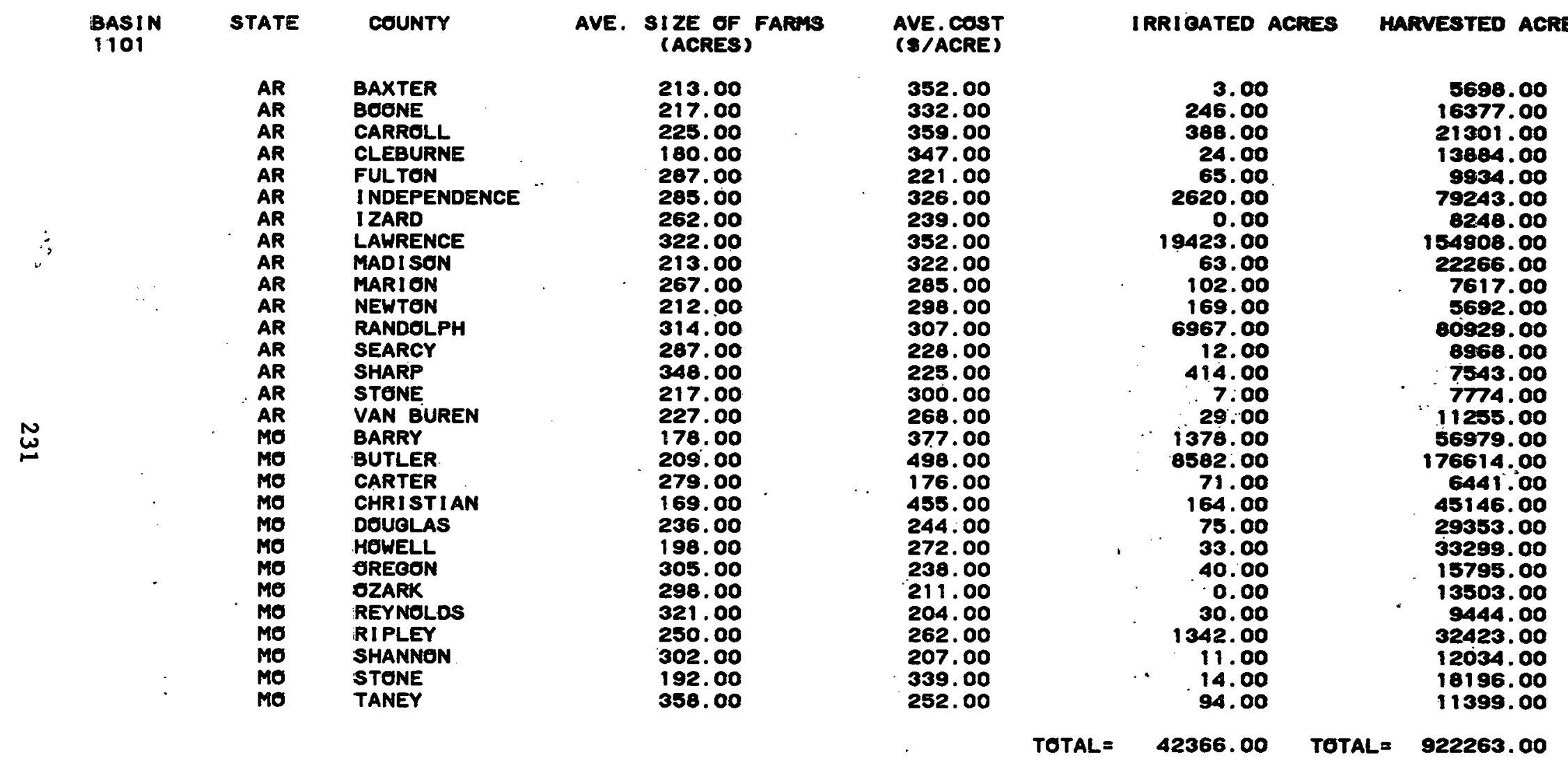

WEIOHTED AVERAGE COST GF AGRI CULTURAL LAND = \$ PERCENT OF HARVESTED ACREAGE BEINO IRRIOATED IS

283. 459 PER ACRE

4.594 
Table E-2 (Concluded)

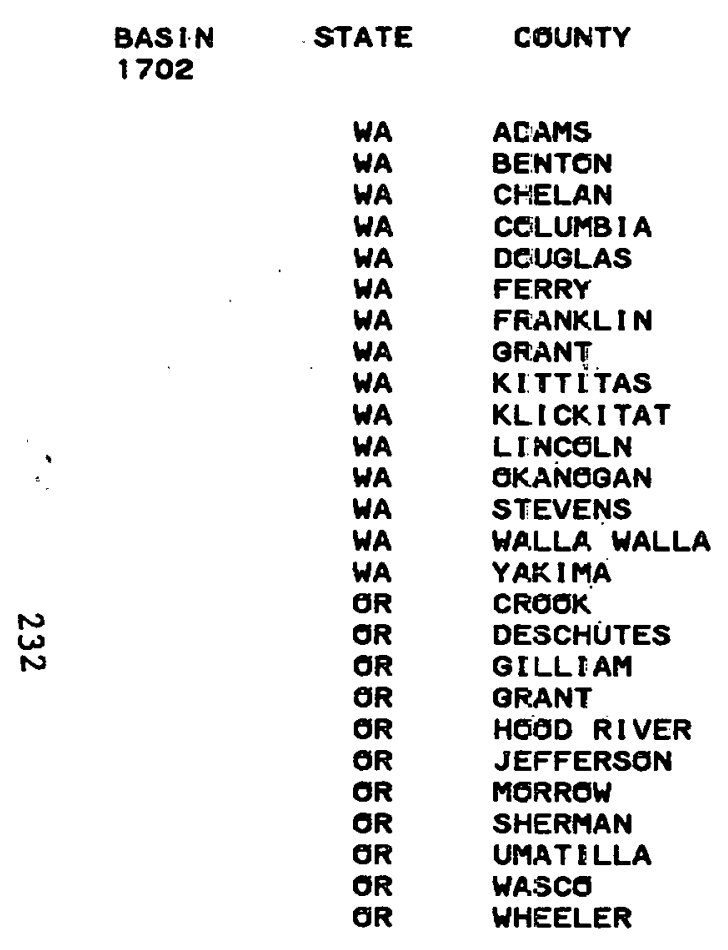

$\begin{array}{cc}\text { AVE. SIZE OF FARMS } & \begin{array}{r}\text { AVE.COST } \\ \text { (ACRES) }\end{array} \\ \text { (\$/ACRE) } \\ 1641.00 & 219.00 \\ 728.00 & 318.00 \\ 77.00 & 1316.00 \\ 1254.00 & 307.00 \\ 1091.00 & 181.00 \\ 5259.00 & 225.00 \\ 784.00 & 363.00 \\ .731 .00 & 378.00 \\ 758.00 & 230.00 \\ 1699.00 & 138.00 \\ 1768.00 & 203.00 \\ 1137.00 & 243.00 \\ 611.00 & 218.00 \\ 1097.00 & 334.00 \\ 432.00 & 369.00 \\ 3509.00 & 81.00 \\ 276.00 & 461.00 \\ 4406.00 & 117.00 \\ 3999.00 & 92.00 \\ 353.00 & 1937.00 \\ 1344.00 & 190.00 \\ 3376.00 & 169.00 \\ 2421.00 & 148.00 \\ 1144.00 & 130.00 \\ 2457.00 & 19.00 \\ 7206.00 & 43.00 \\ & \end{array}$

[RR]BATED ACRES HARVESTED ACRES

105791.00

89802.00

26325.00

7958. DO

22867. DO

3262.00

145630.00

293018.00

68775.00

17452.00

35862 . 00 .

43471.00

13656.00

77839.00 .

255364.00

63618.00

6697.00

7169.00

31987.00

16279.00

52655.00

59238.00

$$
631.00
$$

93809.00

19699.00
6118.00

461483.00 248668.00 248668.00
31754.00 120943.00 275322.00 15345.00 270730.00 451282.00 49747.00 103645.00 103645.00
510779.00 80793.00 84792.00 354732.00 272482.00 46072.00 19075.00 154467.00 154467.00
42710.00 15842.00 67346.00 226909.00 150124.00 433470.00 43370.00 108134.00
17308.00

TOTAL $=1585248.00$

TOTAL $=4613954.00$

WEIGHTED AVERAGE COST OF AGRI CULTURAL LAND = PERCENT OF HARVESTED ACREAGE BEINO IRRIBATED IS

165. 840 PER ACRE

34.358 
Table E-3

ECONOMIC INDICATOR--INCREMENTAL ENERGY DEMAND

BASIN

101

206

302

306

404

602

701

1101

1702
PROJECTED ELECTRIC POWER DEMAND

****** (OICAWATT-HOURS) $* * * * * * *$

$$
\text { (1985) }
$$

(2000)

63E+04

$44 E+05$

$13 E+06$

$11 E+06$

$40 E+05$

S3E+05

B8E+05

33E+05

(3)

$.12 E+06$
INCREMENTAL

$$
\text { DEMAND }
$$

$$
\text { (OWH) }
$$

(percent)

. 19E+03

. $19 E+03$

. 16E+O3

. 24E+03

20E+03

$.81 E+02$

$72 E+02$

.72E+02

$42 E+02$

$.81 E+02$ 
Table E-4

ECONOMIC INDICATOR--ADDITIONAL ENERGY YIELD DUE TO SEASONALITY

\begin{tabular}{c} 
BASIN \\
101 \\
206 \\
302 \\
304. \\
306 \\
404 \\
602 \\
701 \\
1101 \\
1702 \\
\hline 1
\end{tabular}

POTENTIAL ENERO
YIELD IN BTU
$.416 E+13$
$.415 E+16$
$.133 E+15$
$.359 E+15$
$.224 E+15$
$.137 E+15$
$.656 E+5$
$.792 E+5$
$.125 E+5$
$.107 E+6$

MA:IIMUM NO. OF
HAR:JEST PEF YEAR*

1.0
1.0
2.0
2.0
2.0
1.0
1.0
1.0
1.0
1.0

ADOITIONAL ENEROY YIELD IN BTU

0.

$.600 E+14$ $210 E+15$

0.

0.

:.

o.
TOTAL ENEROY YIELO IN BTU
PERCENT INCREASE

\subsection{0}

0.00

45.09

58.4 .1

77.00

0.00

0.00

0.00

0.00

0.00

0.00

$\underset{\omega}{\omega}$

* Based on growing season ( $f$ rost-free days) per year

Subbasin . Range (days)

$\begin{array}{rll}101 & & 120 \text { to } 150 \\ 206 & \cdots & 180 \text { to } 210 \\ 302 & & 210 \text { to } 240 \\ 304 & & 240 \text { to } 300 \\ 306 & & 240 \text { to } 270 \\ 404 & & 120 \text { to } 150 \\ 602 & & 210 \text { tc } 240 \\ 701 & & 120 \text { tc } 150 \\ 1101 & & 180 \text { tc } 210 \\ 1702 & & 120 \text { tc } 180\end{array}$


Table E-5

ENVIRONMENTAL INDICATOR--STREAM DENSITY

BASIN

101

206
302

304

306

404

602

701

1101

1702
STREAM MILES

(MILES)

$134 E+05$

$340 E+04$

$813 E+04$

$120 E+04$

$.105 E+04$

$270 E+04$

$115 E+04$

$156 E+04$

$156 E+04$

$613 E+04$
$.302 E+04$.
BASIN AREA

(SO. MI)

$323 E+05$

$.146 E+05$

420E+05

$.348 E+05$

. 240E+05

$.221 E+05$.

$184 E+05$

1948to5

$447 \varepsilon+05$

$.223 E+05$
$.572 E+08$
STREAM DENSITY

(MI/SO MI)

$.414 E+\infty 0$

$.233 E+00$

$217 E+00$

$.344 E-01$

$.436 E-01$

$122 E+00$

626E-01

349E-01

. 349E-01

$.527 E-01$ 
Table E-6

ENVIRONMENTAL INDICATOR--INCREMENTAL FERTILIZER BURDEN

$\begin{array}{cr} & \text { BASIN } \\ & \\ & 101 \\ & 206 \\ & 302 \\ & 304 \\ & 306 \\ & 404 \\ \tilde{\omega} & 602 \\ & 701 \\ & 1101 \\ & 1702\end{array}$

AVE, RATE OF APPLICATION

(LBS/ACRE)

$$
\begin{array}{r}
.43 E+02 \\
.59 E+02 \\
.68 E+02 \\
.19 E+02 \\
.46 E+02 \\
.30 E+02 \\
.45 E+01 \\
.48 E+02 \\
.31 E+02
\end{array}
$$

$.40 E+02$
NEW ACREAGE

(ACRES)

. $60 E+05$

1 OE+07
$17 E+07$

; $1 E+07$

$\checkmark 3 E+07$

$: 2 E+07$

I $3 E+07$

SE+07

$15 E+07$

$13 E+07$
$.36 E+06$
HARVESTED ACREAGE

(ACRES)

$41 E+06$

$12 E+07$

$.32 E+07$

$.15 E+07$

$.18 E+07$

$.39 E+07$

$16 E+07$

$11 E+08$

$.92 E+06$
$.46 E+07$
INCREMENTAL

FERTILIZER BURDEN

(LBS/ACRE)

$59 E+01$

$38 E+02$

$32 E+02$

S1E+02

$.13 E+02$

$.15 E+02$

24E+02

$59 E+00$

S9E+O0

$66 E+02$

24E+01 
Table E-7

ENVIRONMENTAL INDICATOR--

GROUND WATER USE AS A PERCENT OF DOMESTIC - WATER SUPPLY

\begin{tabular}{|c|c|c|c|c|}
\hline BASIN & & 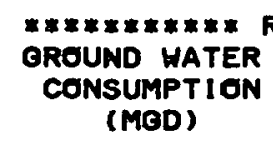 & $\begin{array}{c}\text { REOI ONAL } * * * * * * * * * * * * \\
\text { DOMESTIC WATER } \\
\text { SUPPLY } \\
\text { (MOD) }\end{array}$ & $\begin{array}{c}\text { OROUND WATER } \\
\text { USE } \\
\text { (PERCENT) }\end{array}$ \\
\hline $\begin{array}{l}101 \\
206 \\
302 \\
304 \\
306 \\
404 \\
602 \\
701 \\
1101 \\
1702\end{array}$ & $\begin{array}{l}\ddots \\
\ddots \cdots \\
\ddots \cdots \\
\ddots\end{array}$ & $\begin{array}{l}11 E+03 \\
.38 E+03 \\
.51 E+03 \\
.51 E+03 \\
.51 E+03 \\
.28 E+03 \\
.42 E+02 \\
.19 E+03 \\
.10 E+03 \\
.22 E+03\end{array}$ & $\begin{array}{l}111 E+03 \\
.38 E+03 \\
.51 E+03 \\
.51 E+03 \\
.51 E+03 \\
.28 E+03 \\
.42 E+02 \\
.20 E+03 \\
.11 E+03 \\
.25 E+03\end{array}$ & $\begin{array}{r}98.21 \\
99.42 \\
99.59 \\
99.59 \\
99.59 \\
98.63 \\
100.00 \\
96.06 \\
93.63 \\
86.61\end{array}$ \\
\hline
\end{tabular}


Table E-8

ENVIRONMENTAL INDICATOR--

NONPOINT SOURCE OF POLLUTION

BASIN

101

206

302

304

306

404

602

$\underset{\infty}{\omega}$

1101

1702

SHEET EROSION

(TONS/AC/YR)

60E+02

20E+02

$17 E+02$

$13 E+02$

$.16 E+02$

SOE+01

25E+02

BOEtol

$21 E+02$

. 1OE+01 
Table E-9

SOCIOECONOMIC INDICATOR--INCREMENTAL LABOR REQUIREMENT

BASIN

101

206

302

304

306

404

$\begin{array}{ll}\omega & 602 \\ \omega & 701\end{array}$

1702

HIRED FARM
WORKERS
$.390 E+05$
$.401 E+05$
$.151 E+06$
$.105 E+06$
$.398 E+05$
$.109 E+06$
$.403 E+05$
$.873 E+05$
$.183 E+05$
$.215 E+06$

\begin{abstract}
NEW LANDS
(ACRES)

$601 E+05$

$.102 E+07$

$172 E+07$

109E+07

$126 E+07$

$124 E+07$

$.131 E+07$

. 147E+07

$.128 E+07$

$.356 E+06$
\end{abstract}

\section{HARVESTED \\ (ACRES) \\ INCREMENTAL LABOR REQUIRED}

408E+06

$117 E+07$

$319 E+07$

$145 E+07$

$179 E+07$

. 388E+07

$.162 E+07$

$.112 E+08$

922E+06

$.922 E+06$

$$
\begin{aligned}
& .35 E+05 \\
& .82 E+05 \\
& .79 E+05 \\
& .28 E+05 \\
& .35 E+05 \\
& .33 E+05 \\
& .11 E+05 \\
& .25 E+05 \\
& 17 E+05
\end{aligned}
$$


Table E-10

SOZIOEC JNOMIC INDICATOR--LOCAL ECONOMY

\begin{tabular}{|c|c|c|c|c|}
\hline BASIN & $\begin{array}{l}\text { AGRI CULTURAL } \\
\text { EARMINOS } \\
\text { (SM) }\end{array}$ & $\begin{array}{l}\text { MININO } \\
\text { EARNINOS } \\
\text { (SM) }\end{array}$ & $\begin{array}{l}\text { OTHER } \\
\text { EARNINGS } \\
\text { (SM). }\end{array}$ & $\begin{array}{l}\text { AORI CULTURAL } \\
\text { ECONOMY } \\
\text { (PERCENT) }\end{array}$ \\
\hline $\begin{array}{l}101 \\
206 \\
302 \\
304 \\
306 \\
404 \\
602 \\
701 \\
1101 \\
1702\end{array}$ & $\begin{array}{l}.13 E+03 \\
.27 E+03 \\
.63 E+03 \\
.67 E+03 \\
.44 E+03 \\
.36 E+03 \\
.24 E+03 \\
.77 E+03 \\
.8 E E+02 \\
.5 E E+03\end{array}$ & $\begin{array}{l}.20 E+01 \\
.71 E+02 \\
.31 E+02 \\
.32 E+02 \\
.23 E+02 \\
.23 E+02 \\
.17 E+02 \\
.34 E+02 \\
.80 E+01 \\
.80 E+01\end{array}$ & $\begin{array}{l}16 E+04 \\
.22 E+05 \\
.13 E+05 \\
13 E+05 \\
111 E+05 \\
.83 E+04 \\
.25 E+04 \\
111 E+05 \\
.53 E+03 \\
119 E+04\end{array}$ & $\begin{array}{r}8.400 \\
1.203 \\
4.658 \\
5.076 \\
3.883 \\
4.209 \\
8.724 \\
6.488 \\
13.782 \\
22.302\end{array}$ \\
\hline
\end{tabular}


Table E-11

LEGAL/INSTITUTIONAL INDICATOR--EXISTING FARM SIZES

\begin{tabular}{|c|c|c|c|}
\hline BASIN & 101 & STATE & COUNTY \\
\hline - & & $\begin{array}{l}M E \\
M E \\
M E \\
M E \\
M E \\
M E \\
M E \\
M E \\
M E \\
M E \\
M E \\
M E \\
M E \\
M E\end{array}$ & $\begin{array}{l}\text { ANDROSCOOOIN } \\
\text { AROOSTOEK } \\
\text { FRANKLIN } \\
\text { HANCOCK } \\
\text { KENNEBEC } \\
\text { KNOX } \\
\text { LINCOLN } \\
\text { OXFGRD } \\
\text { PENOBSCOT } \\
\text { PI SCATAOUIS } \\
\text { SAWADAHOC } \\
\text { SOMERSET } \\
\text { WALDO } \\
\text { WASHINOTON }\end{array}$ \\
\hline
\end{tabular}

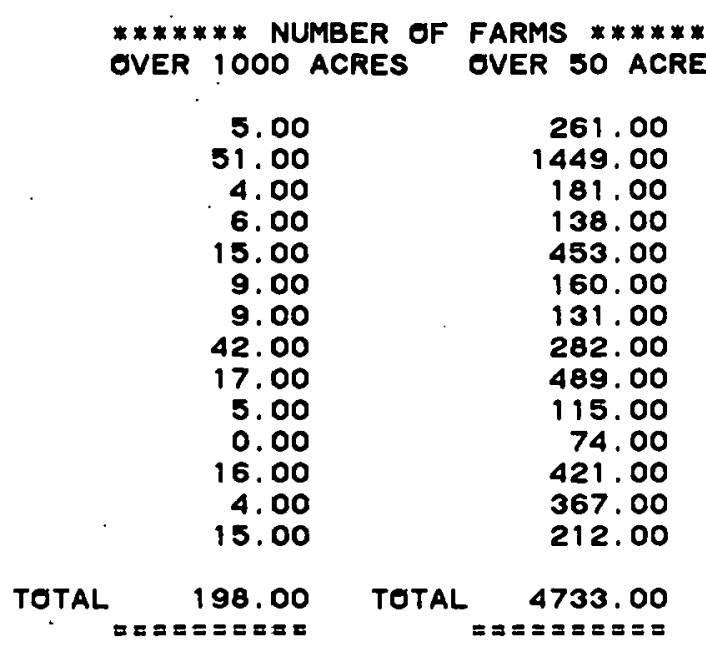

PERCENT OF FARMS
OVER 1000 ACRES

1.92
3.52
2.21
4.35
3.31
5.62
6.87
14.89
3.48
4.35
0.00
3.80
1.09
7.08

4.18 FOR THE ENTIRE BASIN $=\approx=\approx \pi=\Sigma \approx= \pm$ 
Table E-11 (Continued)

BASIN 206 STATE COUNTY

\begin{tabular}{|c|c|}
\hline $\begin{array}{l}M D \\
M D \\
M D \\
M D \\
M D \\
M D \\
M D \\
M D \\
M D \\
V A \\
V A \\
V A \\
V A \\
V A \\
V A \\
V A \\
V A \\
V A \\
V A \\
V A \\
V A \\
V A \\
V A \\
V A \\
W V \\
W V \\
W V \\
W V \\
\text { WV } \\
\text { WV } \\
W V \\
\text { WV }\end{array}$ & 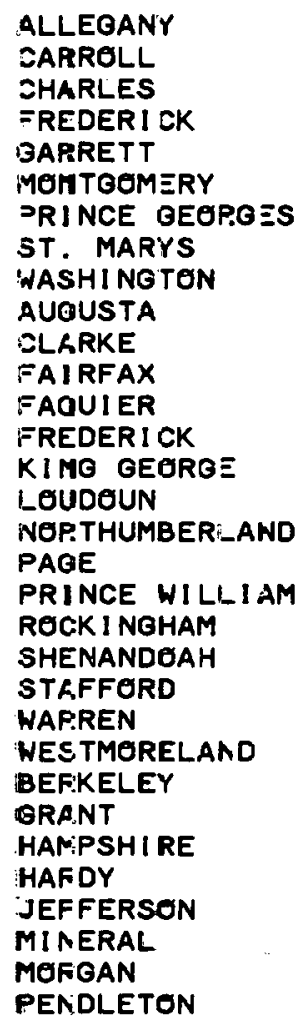 \\
\hline
\end{tabular}

******* NUMB $\equiv R$ OF FARMS $* * * * x: * *$ OVER 1000 ACRES OVER 50 ACP.ES

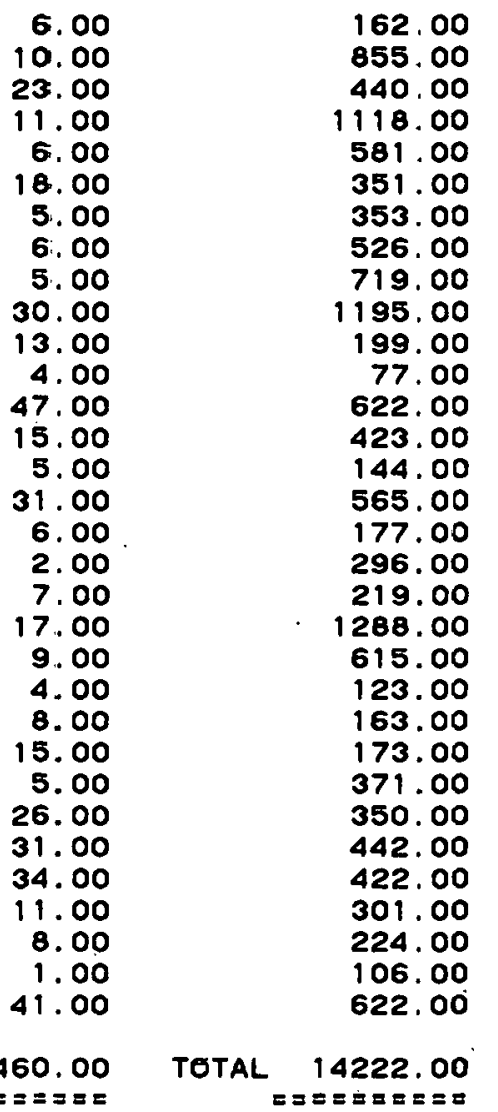

PERCENT OF FARMS

OVER 1000 ACRES

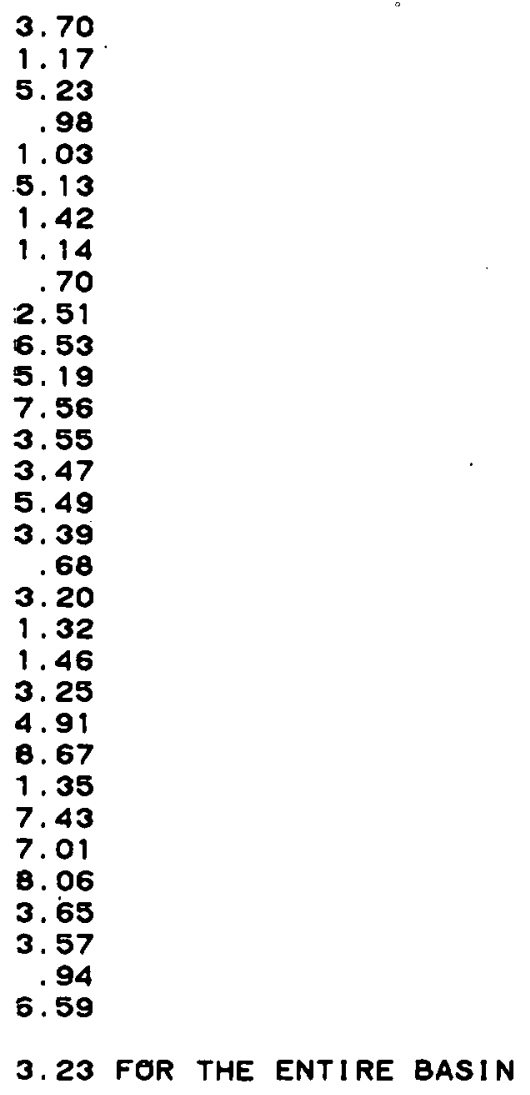


Table E-11 (Continued)

BASIN 302 STATE $\cdot$ COUNTY

ALEXANDER
ANSON
BURKE
CABARRUS
CALDWELL
CATAWBA
CLEVELAND
COLUMBUS
DAVIDSON
DAVIE
FORSYTH
GASTON
OUILFERD
IREDELL
LINCOLN
MCDOWELL
MECKLENBURO
MONTGOMERY
POLK
RANDELPH
RI CHMOND
ROBESON
ROWAN
RUTHERFORD
SCOTLAND
STANLY
SURRY
UNI ON
WILKES
YADKIM
ALLENDALE
BAMBERO
BARNWELL
BEAUFORT
BERKELEY
CALHOUN
CHARLESTON
CHEROKEE
CHESTER
CHESTERFIELO

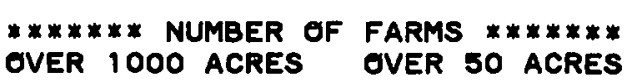

FARMS $* * * * * * *$
OVER 50 ACRES

2.00

19.00

2.00

6.00
3.00

3.00
4.00

8.00

11.00

1.00
5.00

3.00

3.00

7.00

13.00

7.00

0.00

4.00

6.00

1.00

3.00
11.00

11.00
43.00

7.00

3.00

3.00
26.00

7.00

1.00

30.00

10.00

2.00

40.00

19.00

27.00

24.00

13.00

30.00

22.00

9.00

20.00
37.00
358.00

436.00

436.00
430.00

430.00
456.00

456.00

275.00

488.00

737.00

1215.00

706.00

452.00

494.00

318.00

913.00

945.00

402.00

180.00

263.00

218.00

150.00

1112.00

248.00

1329.00

713.00

477.00

158.00

626.00

1064.00

962.00

760.00

806.00

167.00

167.00
300.00

286.00

286.00
84.00

287.00

301.00

157.00

350.00

363.00

491.00
PERCENT OF FARMS
OVER 1000 ACRES

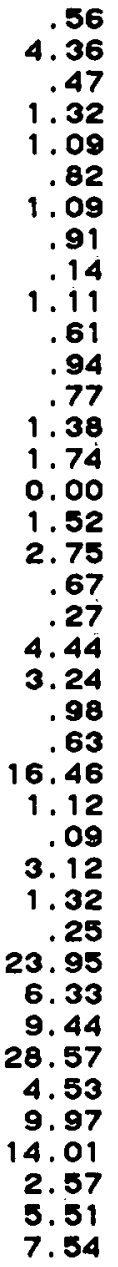


Table E-11 (Continued)

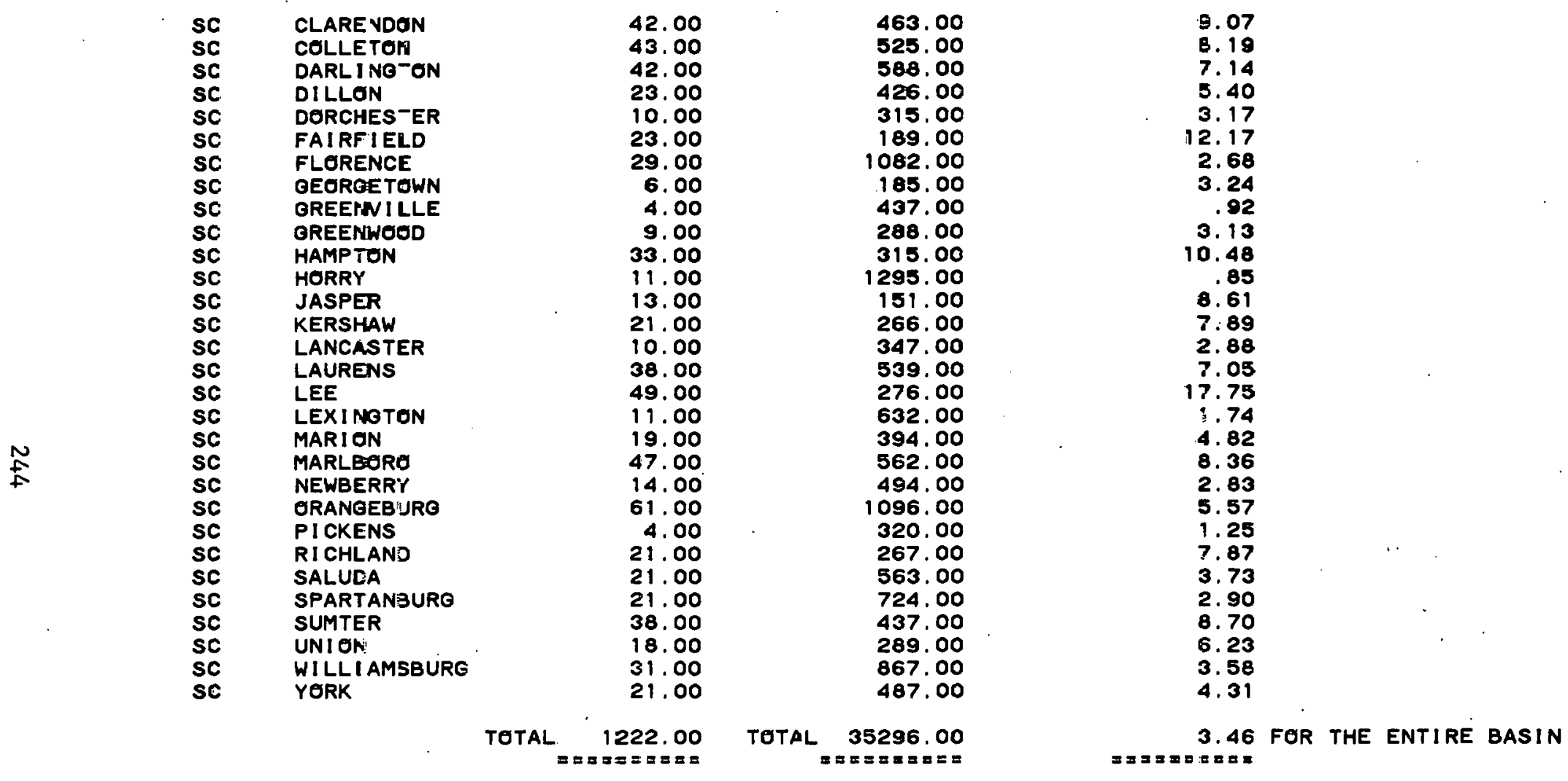


Table E-11 (Continued)

BASIN 304 STATE COUNTY

$\begin{array}{ll}\text { FL } & \text { ALACHUA } \\ \text { FL } & \text { BAKER } \\ \text { FL } & \text { BRADFORD } \\ \text { FL } & \text { BREVARD } \\ \text { FL } & \text { CHARLOTTE } \\ \text { FL } & \text { CITRUS } \\ \text { FL } & \text { CLAY } \\ \text { FL } & \text { COLUMBIA } \\ \text { FL } & \text { DESOTO } \\ \text { FL } & \text { DIXIE } \\ \text { FL } & \text { DUVAL } \\ \text { FL } & \text { FLAOLER } \\ \text { FL } & \text { GILCHRIST } \\ \text { FL } & \text { HAMILTON } \\ \text { FL } & \text { HARDEE } \\ \text { FL } & \text { HERNANDO } \\ \text { FL } & \text { HILLSBOROUOH } \\ \text { FL } & \text { LAFAYETTE } \\ \text { FL } & \text { LAKE } \\ \text { FL } & \text { LEVY } \\ \text { FL } & \text { MADISON } \\ \text { FL } & \text { MANATEE } \\ \text { FL } & \text { MARION } \\ \text { FL } & \text { ORANOE } \\ \text { FL } & \text { OSCEOLA } \\ \text { FL } & \text { PASCO } \\ \text { FL } & \text { PUTNAM } \\ \text { FL } & \text { ST J JOHNS } \\ \text { FL } & \text { SARASOTA } \\ \text { FL } & \text { SEMINOLE } \\ \text { FL } & \text { SUMPTER } \\ \text { FL } & \text { SUWANNEE } \\ \text { FL } & \text { UNION } \\ \text { FL } & \text { VOLUSIA } \\ \text { GA } & \text { BERRIEN } \\ \text { GA } & \text { BROOKS } \\ \text { OA } & \text { CLINCH } \\ \text { GA } & \text { COLOUITTE } \\ \text { GA } & \text { COEK } \\ \text { GA } & \text { ECHOLS } \\ \text { GA } & \text { IRWIN } \\ \text { GA } & \text { LANIER } \\ \text { GA } & \text { LOWNDES } \\ \text { GA } & \text { TIFT } \\ \text { GA } & \text { TURNER } \\ & \end{array}$

******* NUMBER OF FARMS ******* OVER 1000 ACRES OVER 50 ACRES

$$
\begin{array}{r}
52.00 \\
8.00 \\
10.00 \\
23.00 \\
13.00 \\
15.00 \\
18.00 \\
14.00 \\
39.00 \\
9.00 \\
15.00 \\
16.00 \\
15.00 \\
22.00 \\
52.00 \\
13.00 \\
53.00 \\
7.00 \\
59.00 \\
43.00 \\
24.00 \\
59.00 \\
58.00 \\
42.00 \\
49.00 \\
49.00 \\
23.00 \\
9.00 \\
28.00 \\
12.00 \\
26.00 \\
25.00 \\
8.00 \\
35.00 \\
21.00 \\
33.00 \\
7.00 \\
36.00 \\
8.00 \\
2.00 \\
20.00 \\
10.00 \\
19.00 \\
27.00 \\
29.00 \\
190
\end{array}
$$

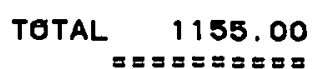

610.00

109.00

162.00

137.00

91.00

110.00

93.00

427.00

318.00

65.00

98.00

62.00

272.00

287.00

504.00

173.00

723.00

272.00

647.00

322.00

498.00

338.00

671.00

323.00

216.00

390.00

223.00

100.00

98.00

94.00

342.00

809.00

148.00

217.00

536.00

499.00

73.00

786.00

359.00

71.00

474.00

136.00

494.00

429.00

338.00

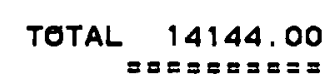

PERCENT OF FARMS

OVER 1000 ACRES

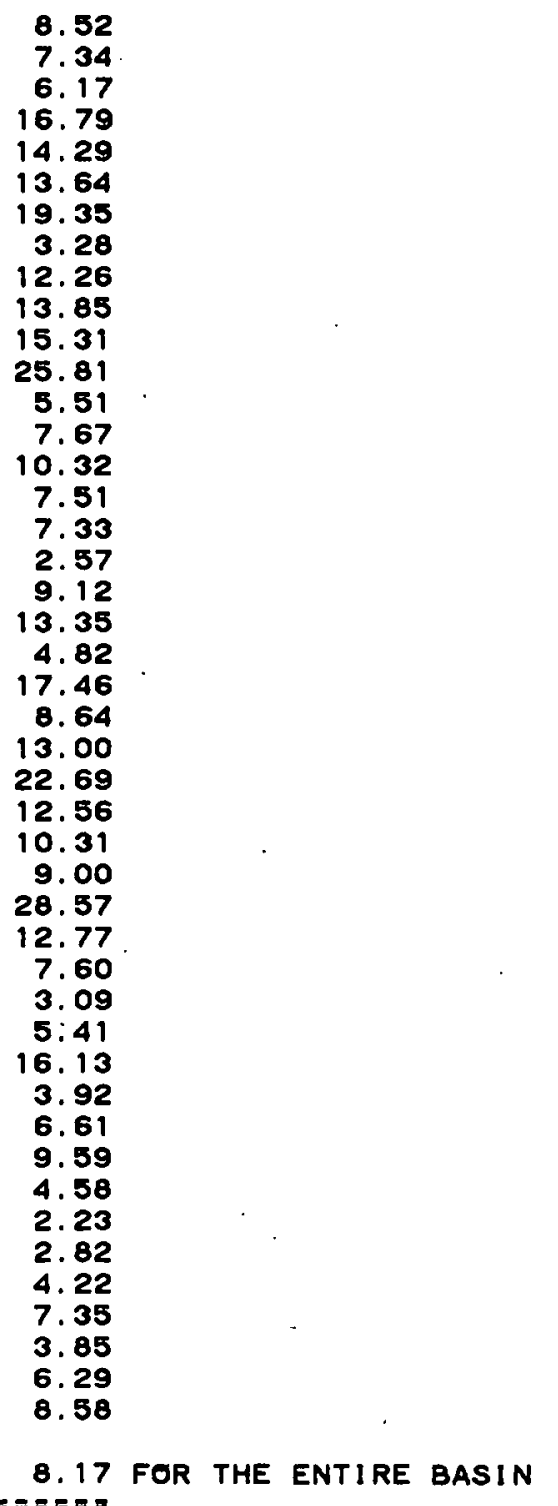


Table E-11 (Continued)

\begin{tabular}{|c|c|c|c|}
\hline \multirow{2}{*}{\multicolumn{2}{|c|}{ BASIN }} & STATE & COLNTY \\
\hline & & $\begin{array}{l}B A \\
B A \\
B A \\
B A \\
B A \\
B A \\
B A \\
B A \\
B A \\
B A \\
B A \\
G A \\
B A \\
B A \\
B A \\
B A \\
G A \\
G A \\
G A \\
B A \\
G A \\
B A \\
G A \\
B A \\
B A \\
B A \\
B A \\
3 A \\
B A \\
B A \\
3 A \\
3 A \\
3 A \\
3 A \\
3 A \\
3 A \\
3 A \\
3 A \\
3 A \\
B A \\
B A\end{array}$ & 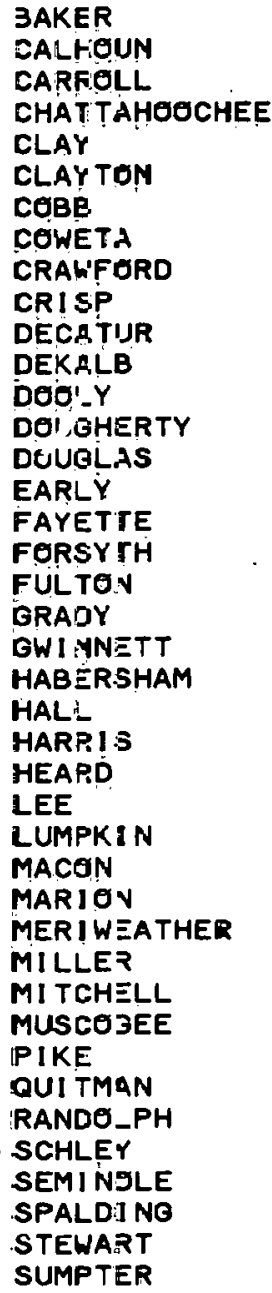 \\
\hline
\end{tabular}

$\begin{array}{rr}* K * * * * * \text { NUMBER OF FARMS ******* } \\ \text { OJER } 1000 \text { ACRES } & \begin{array}{r}\text { OVER } 50 \text { ACRES } \\ 29.00\end{array} \\ 34.00 & 198.00 \\ 5.00 & 135.00 \\ 1.00 & 550.00 \\ 20.00 & 18.00 \\ 0.00 & 104.00 \\ 2.00 & 51.00 \\ 7.00 & 128.00 \\ 20.00 & 275.00 \\ 33.00 & 145.00 \\ 36.00 & 249.00 \\ 0.00 & 480.00 \\ 49.00 & 46.00 \\ 31.00 & 326.00 \\ 0.00 & 124.00 \\ 51.00 & 62.00 \\ 3.00 & 394.00 \\ 7.00 & 173.00 \\ 6.00 & 243.00 \\ 36.00 & 171.00 \\ 1.00 & 654.00 \\ 1.00 & 219.00 \\ 1.00 & 181.00 \\ 13.00 & 397.00 \\ 2.00 & 194.00 \\ 44.00 & 164.00 \\ 4.00 & 175.00 \\ 48.00 & 149.00 \\ 9.00 & 297.00 \\ 26.00 & 145.00 \\ 23.00 & 347.00 \\ 59.00 & 346.00 \\ 2.00 & 493.00 \\ 9.00 & 28.00 \\ 8.00 & 204.00 \\ 46.00 & 48.00 \\ 11.00 & 190.00 \\ 22.00 & 112.00 \\ 10.00 & 248.00 \\ 22.00 & 168.00 \\ 54.00 & 129.00 \\ & 345.00 \\ & \end{array}$

PERCENT OF FARMS

OVER 1000 ACRES
14.65
25.19
91
5.56
19.23
0.00
1.56
2.55
13. 79
13.25
7.50
0.00
15.03
25.00
0.00
12.94
.73
2.88
3.51
5.50
.46
.55
6.70
1.22
1.22
25. 14
2.68
16.16
6.21
7.49
6. 65
14.00
7.14
4.41
16.67
24.21
9. 82
8. 87
5.95
17.05 
Table E-11 (Continued)

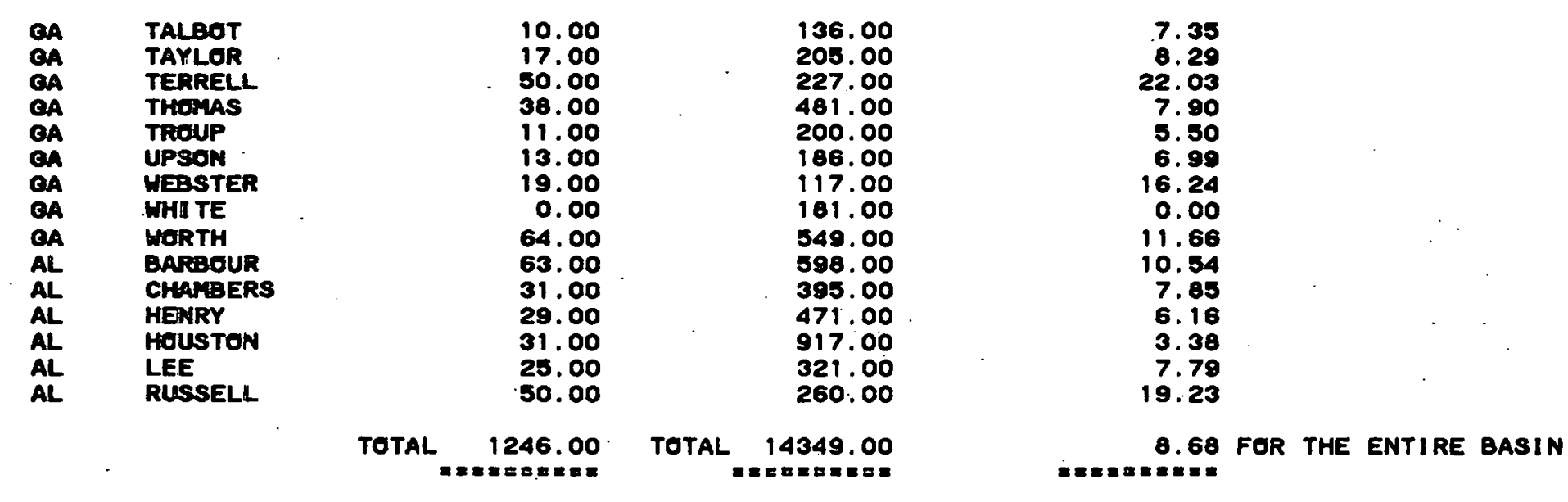


Table E-11 (Continued)

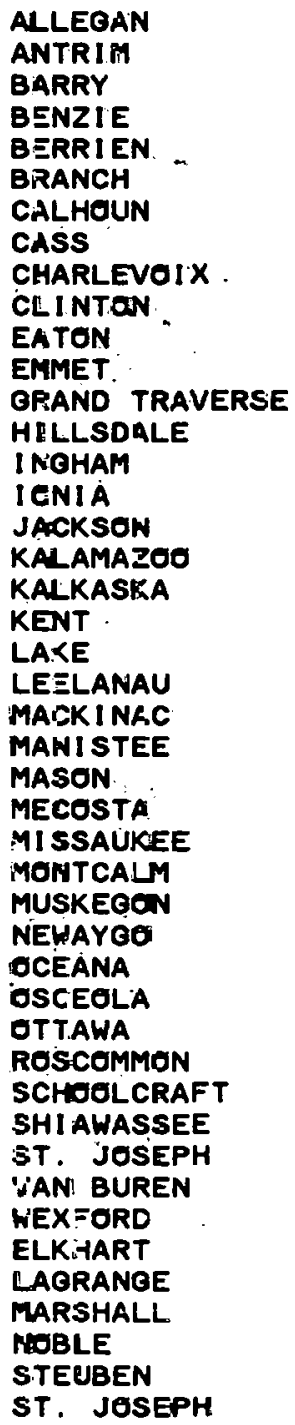

216.00

905.00

143.00

1052.00

1065:00

1188 : 00

869:00.

869.00
194.00

$194.00:$

1337.00

170.00

338.00

1378.00

913.00

913.00
$1158.00:$

969.00

702.00 .

57.00

1147.00

112.00

381.00

381.00
86.00

254.00

435.00

557.00

332.00

1120.00

325.00

672.00

595.00

503.00

1013.00

21.00

36.00

1159.00

963.00

1147.00 .

198.00

1134.00

1064.00

995.00

649.00

649.00
801.00
7.00

TGTAL

TOTAL 32175.00 $=z=\geq \approx=\geq=$

PERCENT OF FARMS

OVER. 1000 ACRES

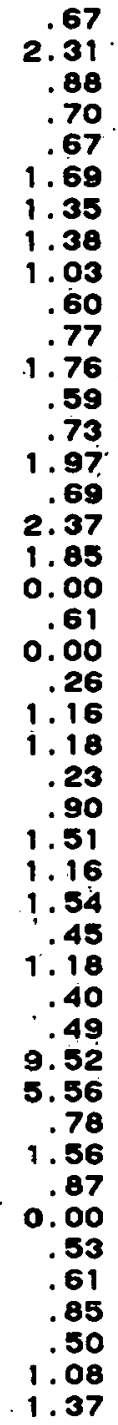

1.37

98 FOR THE ENTIRE BASIN 
Table E-11 (Continued)

BASIN 602 STATE COUNTY

\begin{tabular}{|c|c|}
\hline $\begin{array}{l}T N \\
T N \\
T N \\
T N \\
T N \\
T N \\
T N \\
T N \\
T N \\
T N \\
T N \\
T N \\
T N \\
T N \\
T N \\
T N \\
T N \\
T N \\
T N \\
T N \\
T N \\
K Y \\
K Y \\
A L \\
A L \\
A L \\
A L \\
A L \\
A L \\
A L \\
A L \\
A L \\
A L \\
A L \\
M S\end{array}$ & $\begin{array}{l}\text { BEDFORD } \\
\text { BENTON } \\
\text { COFFEE } \\
\text { DECATUR } \\
\text { FERANKLIN } \\
\text { GILES } \\
\text { HARDIN } \\
\text { HENDERSON } \\
\text { HENRY } \\
\text { HI CKMAN } \\
\text { HUMPHREYS } \\
\text { LAWRENCE } \\
\text { LEWIS } \\
\text { LINCELN } \\
\text { MARSHALL } \\
\text { MAURY } \\
\text { MOURE } \\
\text { PERRY } \\
\text { WAYNE } \\
\text { CALLOWAY } \\
\text { MARSHALL } \\
\text { COLBERT } \\
\text { DEKALB } \\
\text { FRANKLIN } \\
\text { JACKSON } \\
\text { LAUDERDALE } \\
\text { LAWRENCE } \\
\text { LIMESTENE. } \\
\text { MADI SON } \\
\text { MARSHALL } \\
\text { MORGAN } \\
\text { I SHOMINGO }\end{array}$ \\
\hline
\end{tabular}

******* NUMBER OF
FARMS *********

10:00

3.00

13.00
9.00

11.00

19.00

19.00

14.00
12.00

12.00

7. 00

11.00

3.00

16.00

6.00

17.00

0.00

8.00

12.00

9.00

1.00

29.00

4.00
7.00

7.00
32.00

24.00

41.00

41.00

43.00

86.00
5.00

5.00
11.00

3.00

ISHOMINOE

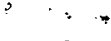

$\because \cdots:$
TOTAL

488.00

$=\Sigma===\Sigma=\approx==$
392.00

735.00

480.00

817.00

1354.00

535,00

935.00

961.00

596.00

516.00

1190.00

203.00

1388.00

923.00

923.00
1406.00

342.00

284.00

595.00

825.00

601.00

504.00

1420.00

803.00

982.00

1032.00

943.00

878.00

878.00

894.00

955.00

904.00

445.00

TOTAL 25943.00

$==== \pm==$
PERCENT OF FARMS

OVER 1000 ACRES

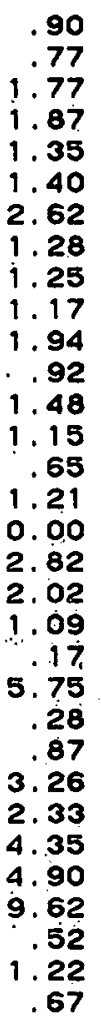

$1.8 B$ FOR THE ENTIRE BASIN 
Table E-11 (Continued)

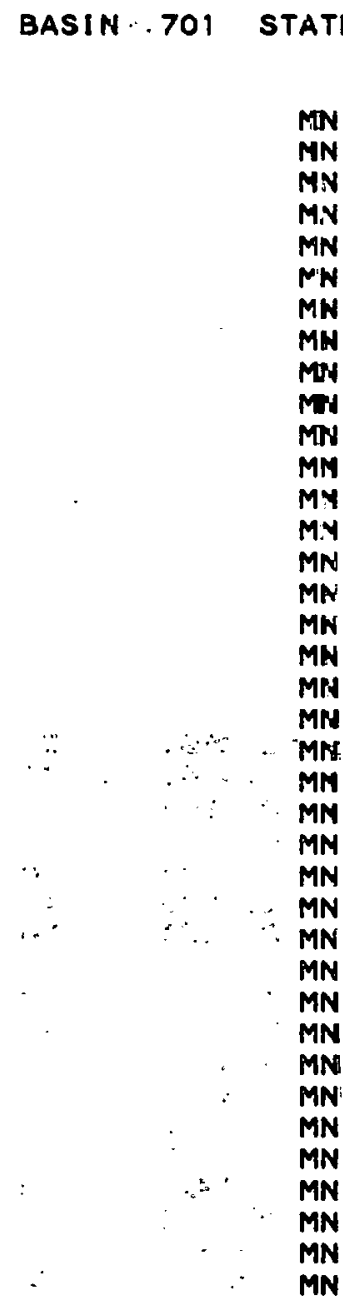

COLNTY

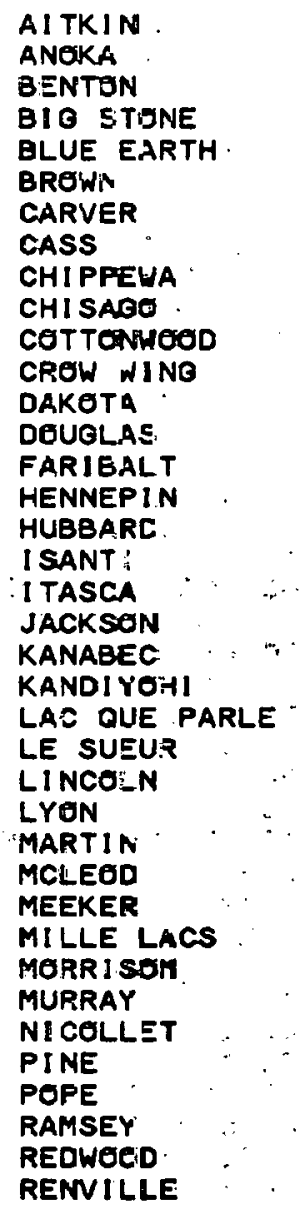

******* NUMBER OF OVER 1000 ACRES

FARMS $* * * * * * *$

9.00
6.00
5.00
36.00
22.00
6.00
3.00
17.00
19.00
2.00
25.00
11.00
23.00
7.00
32.00
1.00
6.00
6.00
8.00
25.00
9.00
21.00
25.00
12.00
15.00
29.00
35.00
7.00
16.00
0.00
20.00
19.00
16.00
10.00
24.00
0.00
30.00
51.00

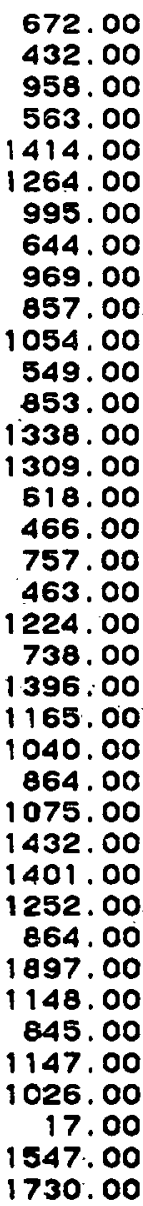

672.00

432.00
958.00

53.00

995.00

44.00

969.00
357.00

054.00

33.00

309.00

466.00

57.00

224.00

738.00

040.00

075.00

432.00

401.00

864.00

897.00

845.00

1147.00

17.00

1730.00
PERCENT OF FARMS

OVER 1000 ACRES

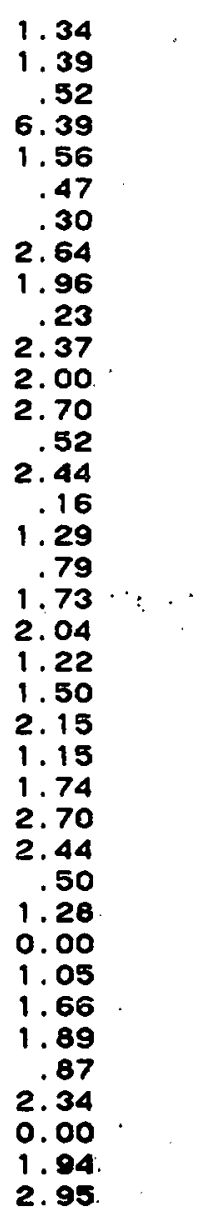


Table E-11 (Continued)

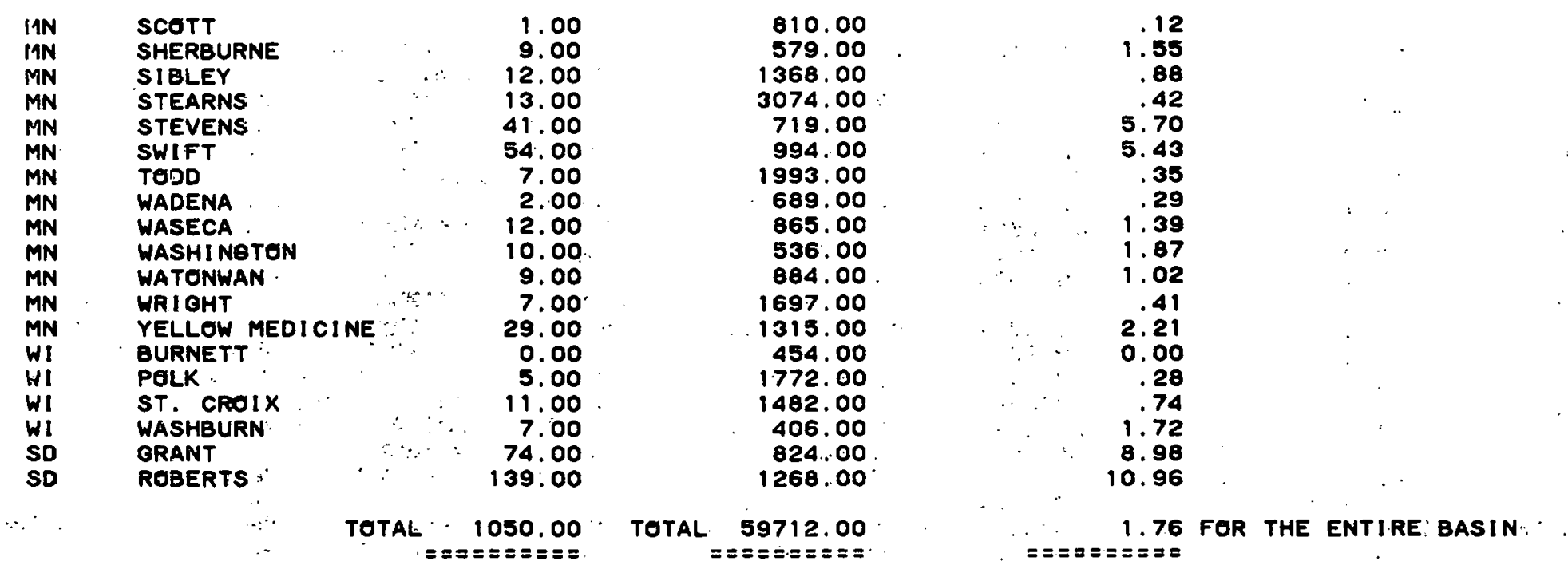


Tajle E-11 (Continued)

\section{BASIN 1101 STATE COUHTY}

$\begin{array}{ll}\text { AR } & \text { BAXTER } \\ \text { AR } & \text { BOENE } \\ \text { AR } & \text { CARRLLL } \\ \text { AR } & \text { CLEBLRNE } \\ \text { AR } & \text { FULTEN } \\ \text { AR } & \text { INDEPENDENCE } \\ \text { AR } & \text { I ZARD } \\ \text { AR } & \text { LAWRENCE } \\ \text { AR } & \text { MADISIN } \\ \text { AR } & \text { MARION } \\ \text { AR } & \text { NEWTON } \\ \text { AR } & \text { RANDELPH } \\ \text { AR } & \text { SEARCY } \\ \text { AR } & \text { SHARP } \\ \text { AR } & \text { STONE } \\ \text { AR } & \text { VAN BUREN } \\ \text { MO } & \text { BARRY } \\ \text { MO } & \text { BUTLEP } \\ \text { MO } & \text { CARTEP. } \\ \text { MO } & \text { CHRISTIAN } \\ \text { MO } & \text { DOUGLAS } \\ \text { MO } & \text { HOWELL } \\ \text { MO } & \text { OREGON } \\ \text { MO } & \text { GZARK } \\ \text { MO } & \text { REYNOLDS } \\ \text { MO } & \text { RIPLEY } \\ \text { MO } & \text { SHANNON } \\ \text { MO } & \text { STONE } \\ \text { MO } & \text { TANEY } \\ & \end{array}$

******** NLMBER OF FARMS $* * * * * * *$ OVER 1000 ACRES OVER 5O ACRES

$$
\begin{array}{r}
9.00 \\
32.00 \\
18.00 \\
13.00 \\
20.00 \\
52.00 \\
19.00 \\
50.00 \\
17.00 \\
17.00 \\
8.00 \\
38.00 \\
24.00 \\
20.00 \\
17.00 \\
8.00 \\
18.00 \\
27.00 \\
9.00 \\
17.00 \\
23.00 \\
17.00 \\
32.00 \\
31.00 \\
11.00 \\
11.00 \\
9.00 \\
13.00 \\
34.00 \\
110
\end{array}
$$

ToTAL
324.00

906.00

871.00

570.00

655.00

852.00

625.00

716.00

896.00

442.00

392.00

650.00

533.00

466.00

466.00

481.00
1356.00

1356.00

168.00

1000.00

1072.00

1314.00

1314.00
719.00

719.00

664.00
282.00

282.00

373.00

670.00

526.00 $== \pm= \pm . \pm=$
TOTAL 19420.00
PERCENT OF FARMS OVER 1000 ACRES
2.78
3.53
2.07
2. 28
3.05
6. 10
6. 10
3.04
6.98
1.90
3.85
2. 04
5.85
4.50
3.98
3.65
1.66
1.33
2.99
1.70
2. 15
1.29
4.45
4.67
3.90
2. 24
2. 41
1.94

3. 16 FOR THE ENTIRE BASIN $==\Sigma x==\Sigma= \pm 8$ 
Table E-11 (Concluded)

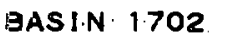

STA'TE

COUNTY

$\begin{array}{ll}\text { WA } & \text { ADAMS } \\ \text { WA } & \text { BENTON } \\ \text { WA } & \text { CHELAN } \\ \text { WA } & \text { COLUMBIA } \\ \text { WA } & \text { DOUGLAS } \\ \text { WA } & \text { FERRY } \\ \text { WA } & \text { FRANKLIN } \\ \text { WA } & \text { GRANT } \\ \text { WA } & \text { KITTITAS } \\ \text { WA } & \text { KLICKITAT } \\ \text { WA } & \text { LINCOLN } \\ \text { WA } & \text { OKANOGAN } \\ \text { WA } & \text { STEVENS } \\ \text { WA } & \text { WALLA WALLA } \\ \text { WA } & \text { YAKIMA } \\ \text { OR } & \text { CROOK } \\ \text { OR } & \text { DESCHUTES } \\ \text { OR } & \text { GILLIIAM } \\ \text { OR } & \text { GRANT } \\ \text { OR } & \text { HOOD RIVER } \\ \text { OR } & \text { JEFFERSON } \\ \text { OR } & \text { MORROW } \\ \text { OR } & \text { SHERMAN } \\ \text { OR } & \text { UMATILLA } \\ \text { OR } & \text { WASCO } \\ \text { OR } & \text { WHEELER }\end{array}$

*\#\#*\#\#* NUY

NUMBER OF FARMS ******* OVER 1000-ACRES

OVER 50 ACRES

350.00
95.00
11.00
80.00
274.00
52.00
99.00
207.00
46.00
149.00
509.00
193.00
109.00
201.00
91.00
77.00
19.00
135.00
154.00
0.00
47.00
182.00
138.00
317.00
156.00
62.00

6460

412.00

320.00

209.00

455,00

134.00

134.00
653.00

653.00
1266.00

1266.00
434.00

372.00

804.00

667.00

865.00

452.00

1484.00

224.00

242.00

1.66 .00

242.00

178.00

295.00

281.00

188.00

725.00

351.00

91.00

62.00

$9 ! .00$

TOTAL 12156:00

$== \pm=====$
PERCENT OF FARMS

OVER 1000 ACRES

54.18
23.06
3.44
38.28
60.22
38.81
15.16
16.35
10.60
40.05
63.31
28.94
12.60
44.47
6.13
34.38
7.85
81.33
63.64
0.00
15.93
64.77
73.40
43.72
44.44
68.13

30.87 FOR THE ENTIRE BASIN 
Table E-12

LIGAL/ INSTITUTIONAL INDICATOR--

WATER QUALITY COMPACTS AND POLLUTED STREAMS

BASIN

101

206
302
304

304

306

404
602

701

1101

1702
NUMBER OF STREAMS NOT MEETINB

COMPACTS WATER QUALITY STANDARDS (PERCENT)
5.00
10.00
30.00
40.00
30.00
5.00
5.00
5.00
50.00
40.00 
Table E-13

LEGAL/INSTITUTIONAL INDICATOR-MINIMUM DAYS REQUIRED FOR

IRRIGATION WATER PERMIT(S) APPLICATION

BASIN

101

206

302

304

306

406

404

602

70

1.101

1702
MINIMUM DAYS

0.0
180.0

180.0
30.0

180.0

180.0

0.0

0.0
120.0

0.0

60.0 
Table E-14

LEGAL/INST ITUTIONAL INDICATOR--

PFOPORTION GF SOLE-SOURCE AQUIFER AREA TO THE BASIN AREA

BASIN

206

302

N
UNDERLYINO

OLE-SOURCE
AQUIFER

( SQ.MILES

-0 .

-0 .

$-0$.

-0 .

-0 .

-0 .

$-0$

$-0$

-0 .
BASIN AREA

(SO.MILES)

$.323 E+05$

. 1 $46 E+05$

$.420 E+05$

$.348 E+05$

$.240 E+05$

.221E+05

$.184 E+08$

$.447 E+05$

.223E+DS

$.572 E+05$
PROPERTION

(PERCENT)

0.000

0.000

0.000

0.000

0.000

0.000

0.000

0.000

0.000

0.000
0.000 
Appendix $\mathrm{F}$

MANUAL OF WORKSHEETS FOR

EVALUATING ENERGY FARMING AREAS 
THIS PAGE

\section{WAS INTENTIONALLY LEFT BLANK}


Table F-1

ECONOMICS WORKSHEET 1--POTENTIAL ENERGY (YEAR 2000)

A.

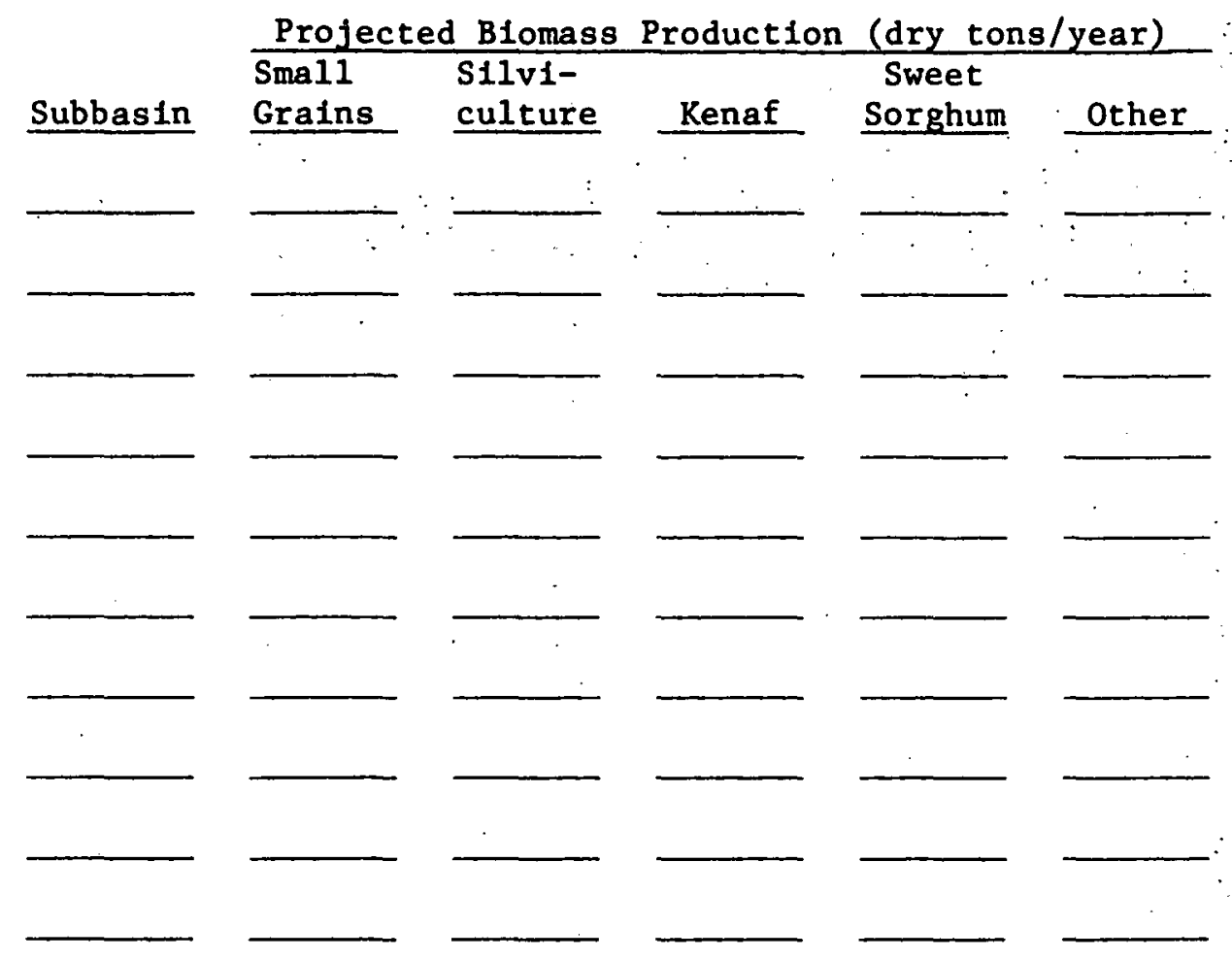

B. Heating values are:
1. Small grains -- $15.0 \times 10^{6} \mathrm{Btu} / \mathrm{dry}$ ton
2. Silviculture - $17.0 \times 10^{6} \mathrm{Btu} / \mathrm{dry}$ ton
3. Kenaf - $15.0 \times 10^{6} \cdot \mathrm{Btu} / \mathrm{dry}$, ton
4. Sweet Sorghum - $15.0 \times 10^{6}$ Btu/dry ton
5. Other $--0^{*}$

* Another biomass crop may be added in this position.

Source: SRI's Land Penetration Model (described in this report) 
Table F-2

ECONOMICS WiORKSHEET 2--COST OF AGRICULTURAL LAND

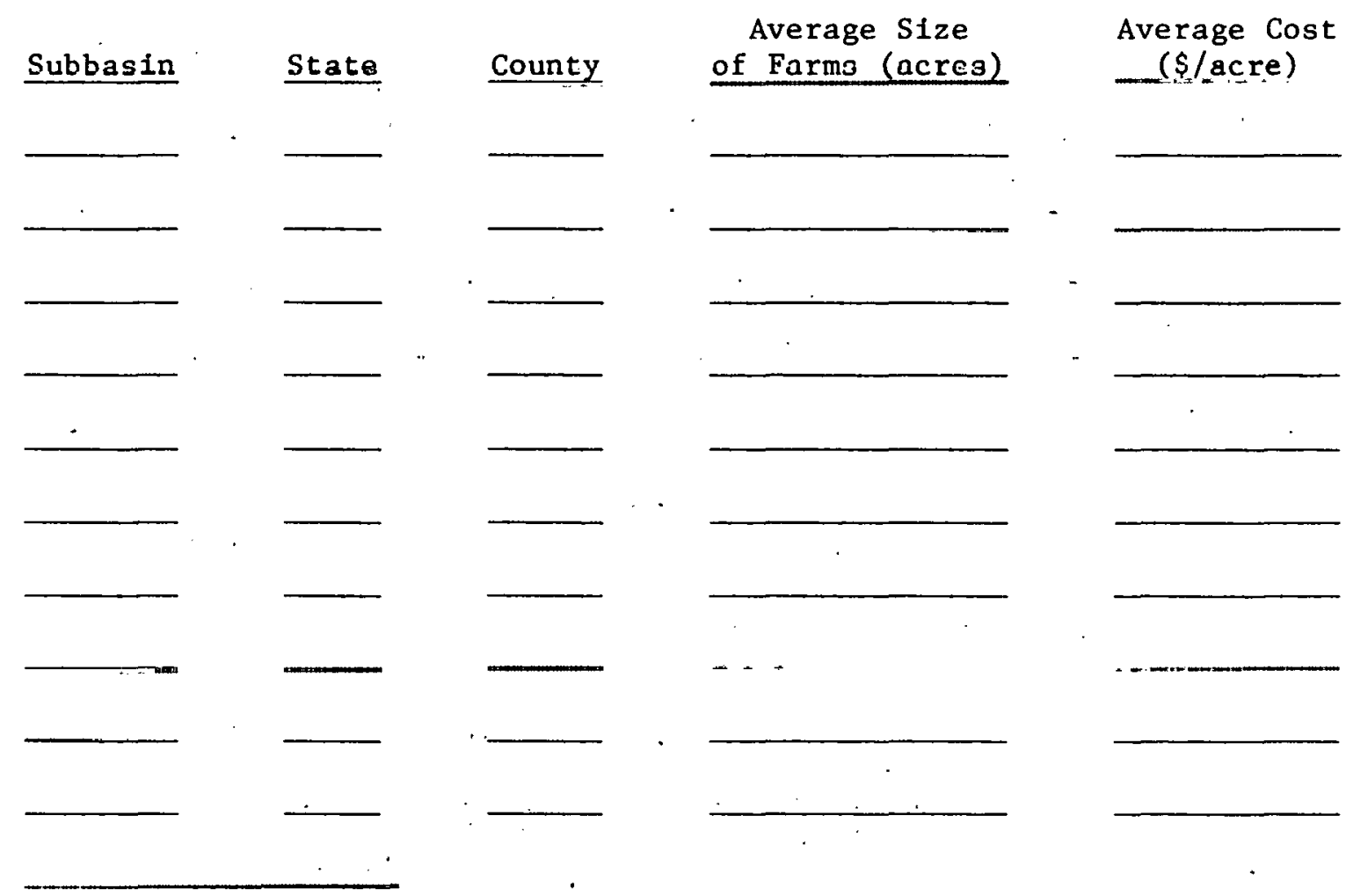

Source: U.S. Department of Commerce, 1974 Census of Agriculture (1977). 
Table F-3

ECONOMICS WORKSHEET 3--IRRIGATION OF HARVESTED CROPLAND

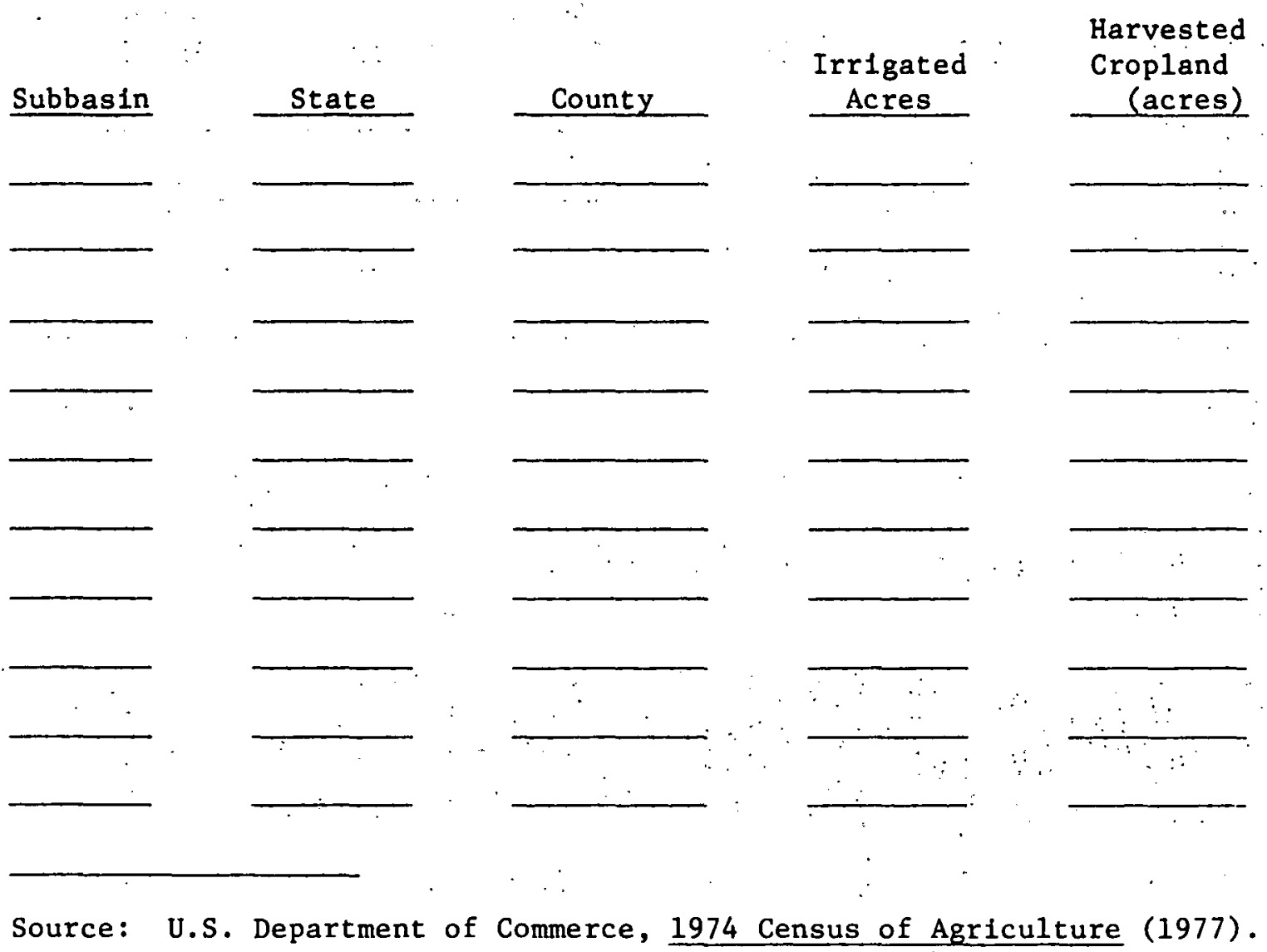


Table $F-4$

ECONOMICS WORKSHEET 4--INCREMENTAL ENERGY DEMAND

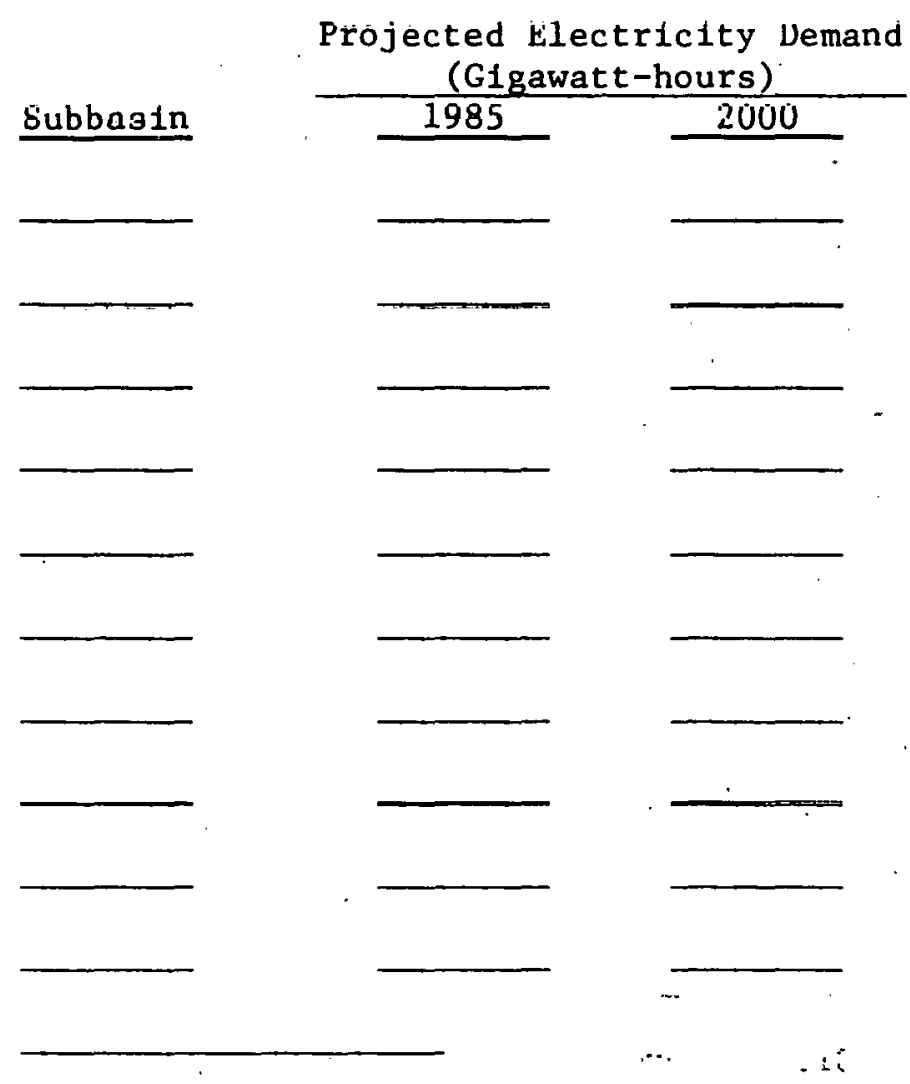

Source: U.S. Water Resources Council, The Second National Water Assessment, Volume A-1 (April 1978). 
Table F-5

ECONOMICS WORKSHEET 5--SEASONALITY OF BIOMASS CROPS

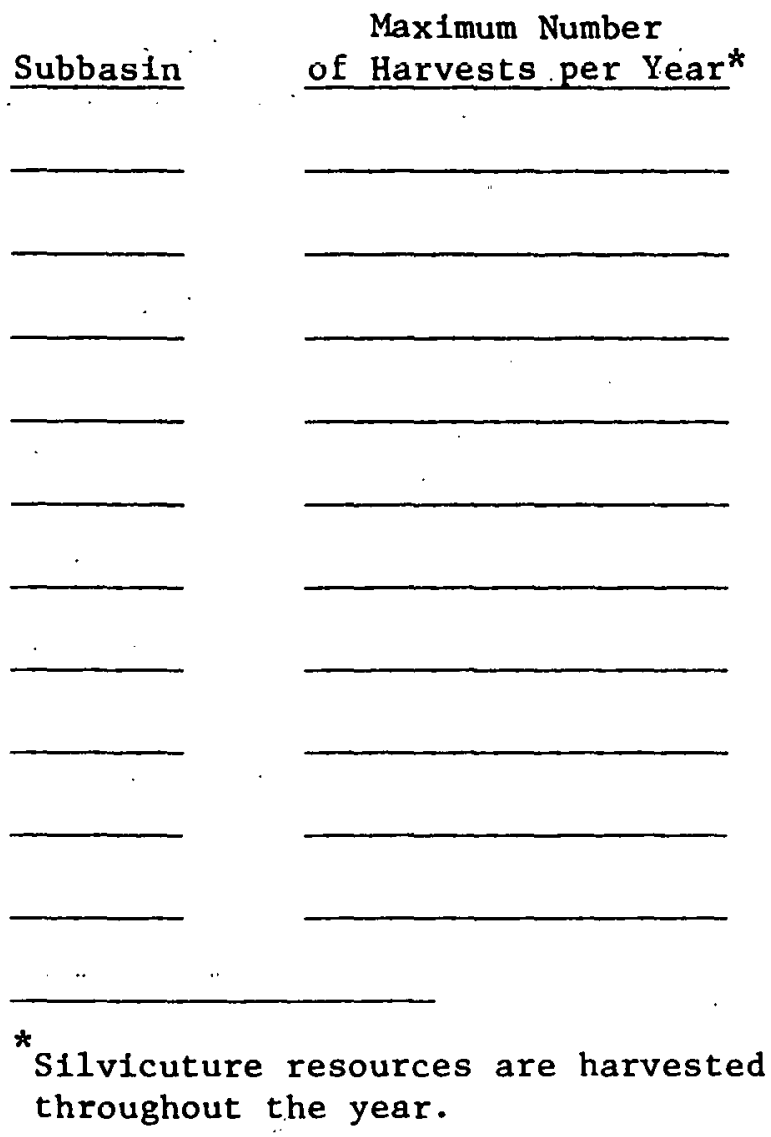

Source: Department of Agriculture personnel in each subbasin, personal communications (1979). 
Table F-6

ENVIRONMENTAL WORKSHEET 1--STREAM DENSITY

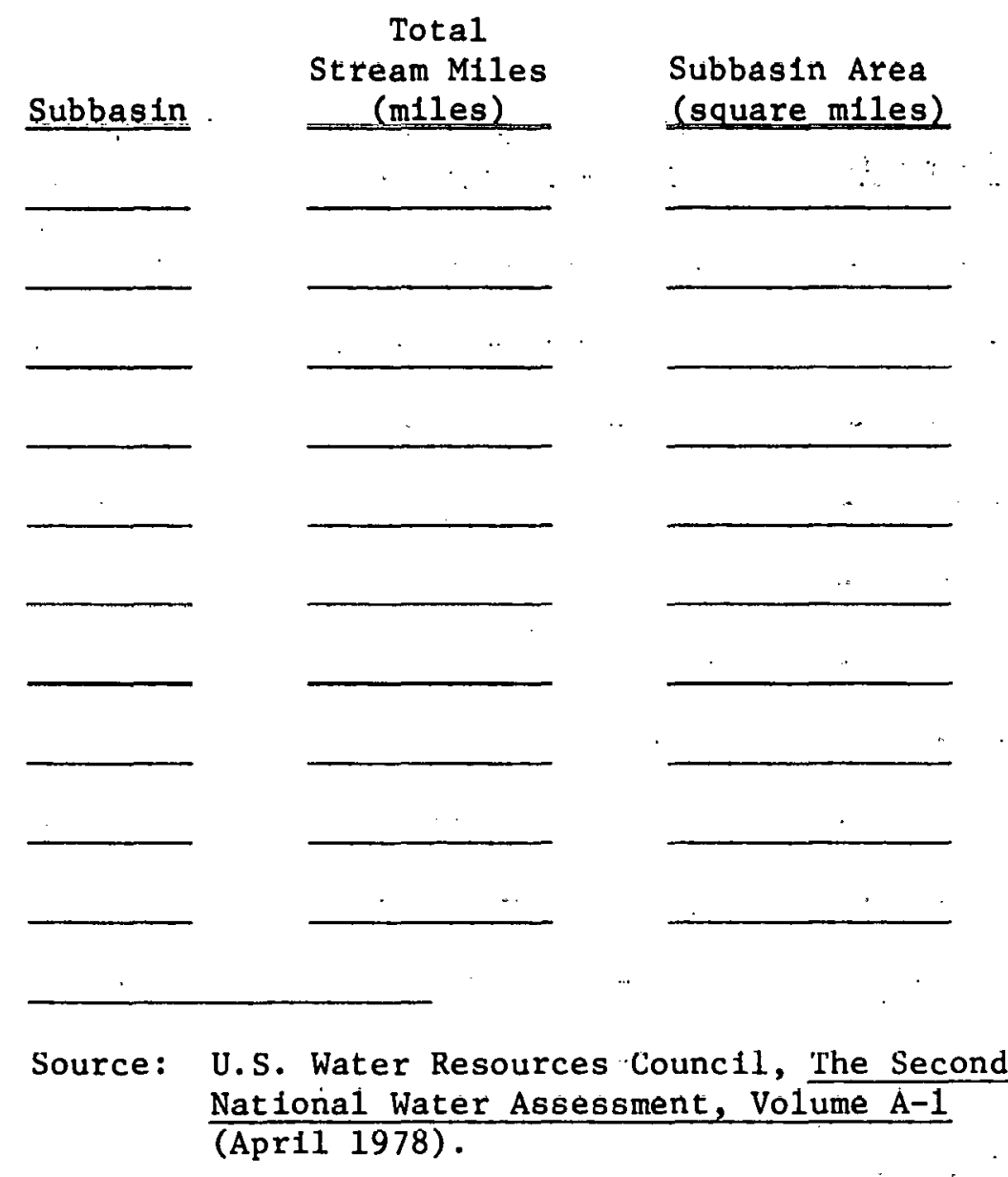


Table F-7

ENV IRONMENTAL WORKSHEET 2-INCREMENTAL FERTILIZER BURDEN (Part A)

Subbasin

$$
\text { Rate of Appilcation * }
$$

(pounds per acre)

New Lands ${ }^{\dagger}$

(acres)
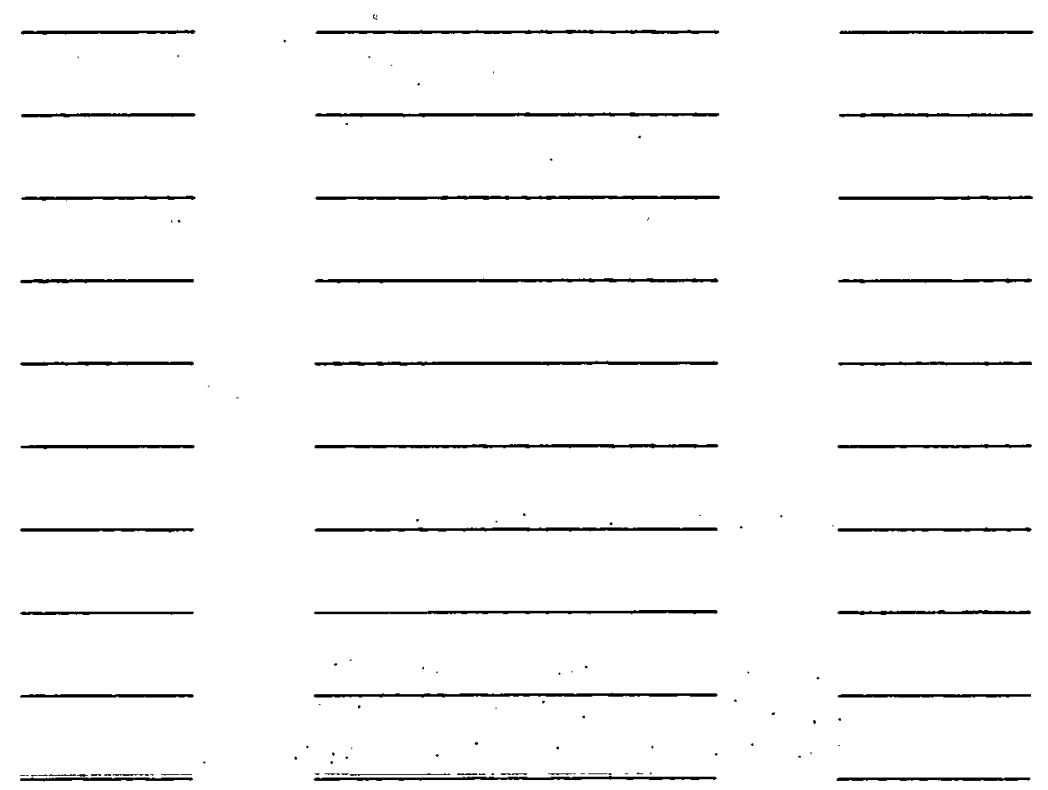

*From Part B.

From Part C. 
Table $F-8$

ENVIRONMENTAL WORKSHEET 2--INCREMENTAL FERTILIZER BUREEN

(Part B)

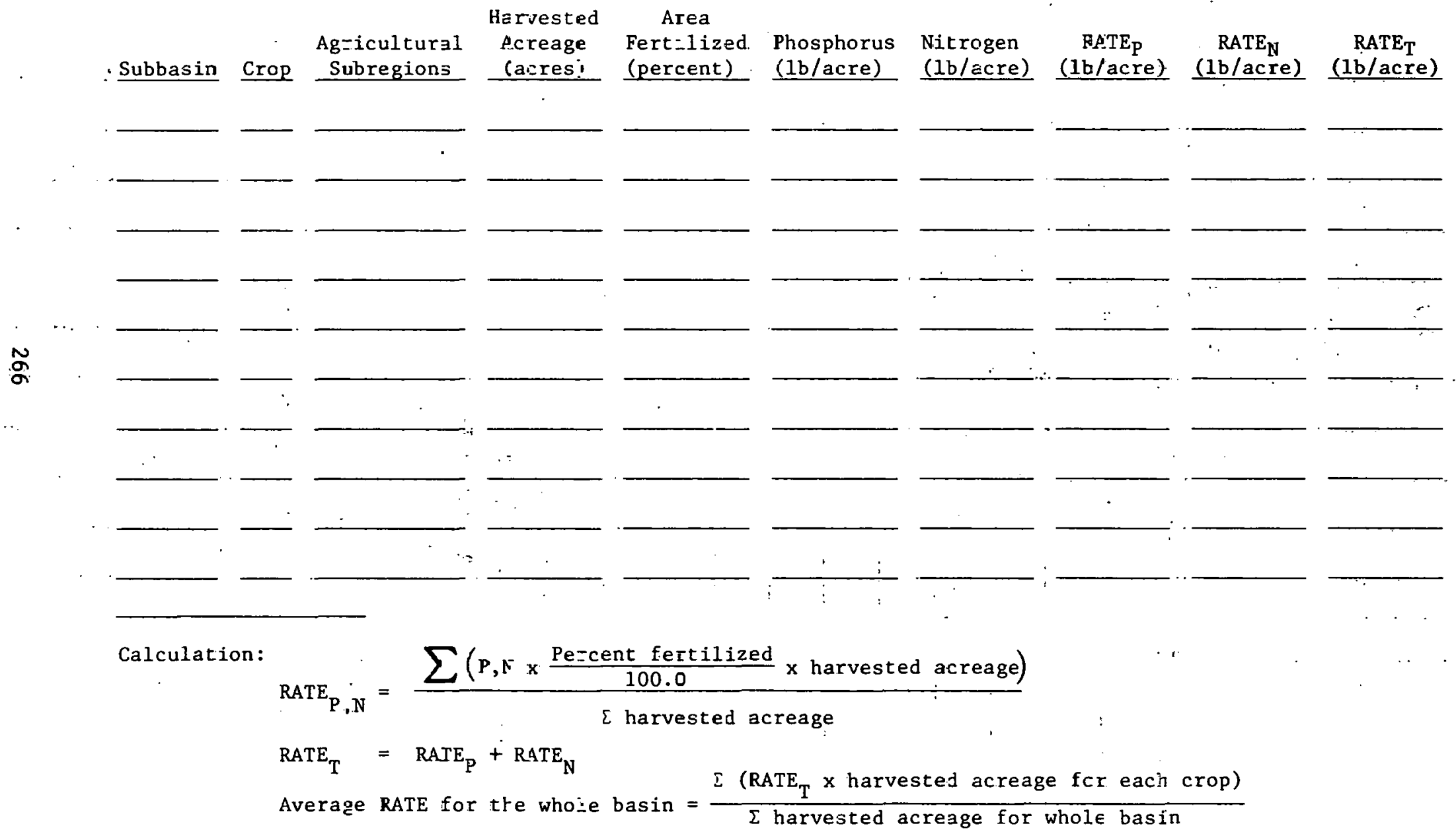

Source: U.S. Department of Agrjculture, Crop Yield Response to Fertilizer in the U.S., "Statistical Bulletin No. 431 (August 1968i. 
Table F-9

ENVIRONMENTAL WORKSHEET 2--INCREMENTAL FERTILIZER

BURDEN WORKSHEET

(Part C)

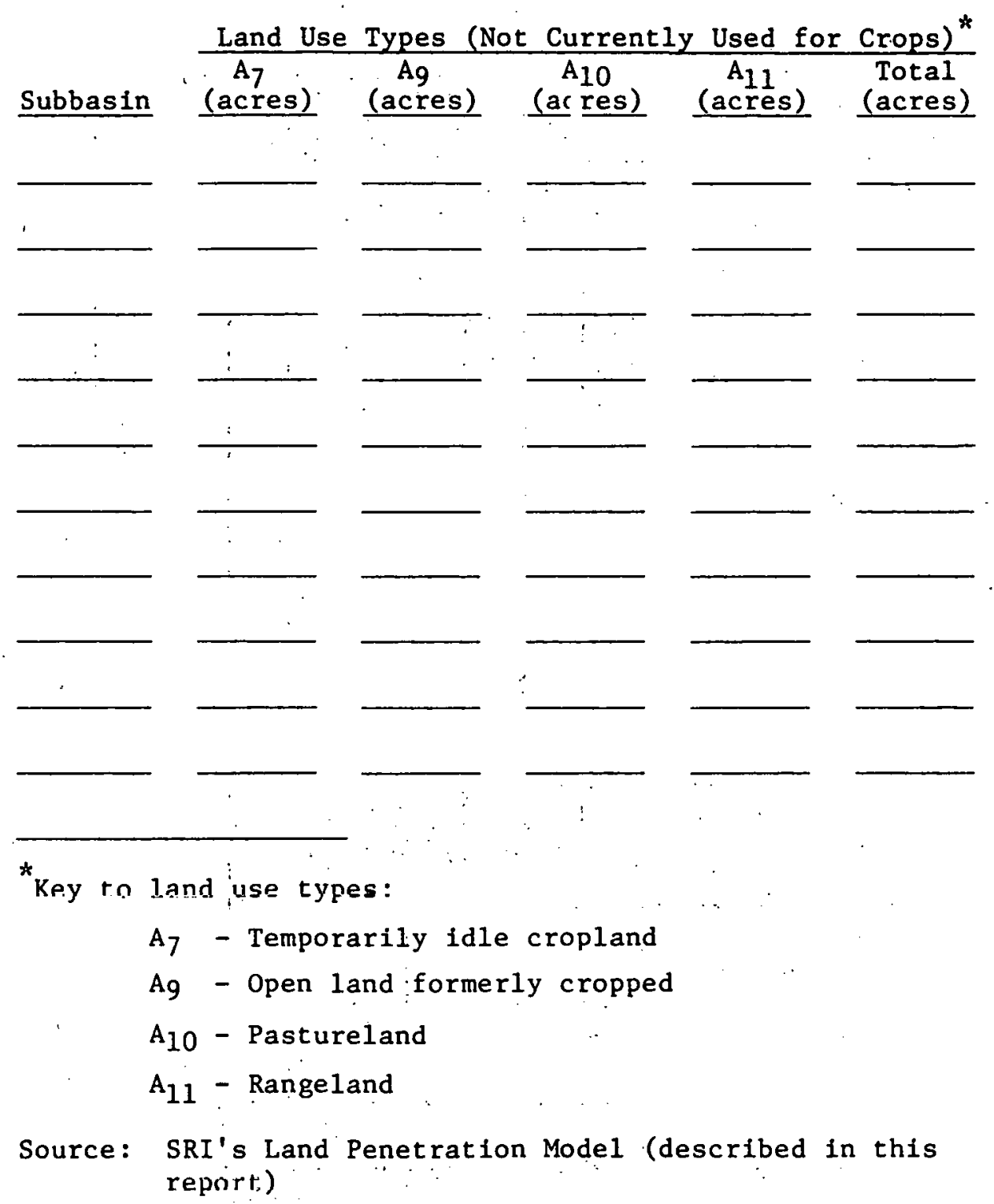


Table F-10

ENVIRONMENTAL WORKSHEET 3--GROUND-WATER USE

(Millions of Gallons.per Day)

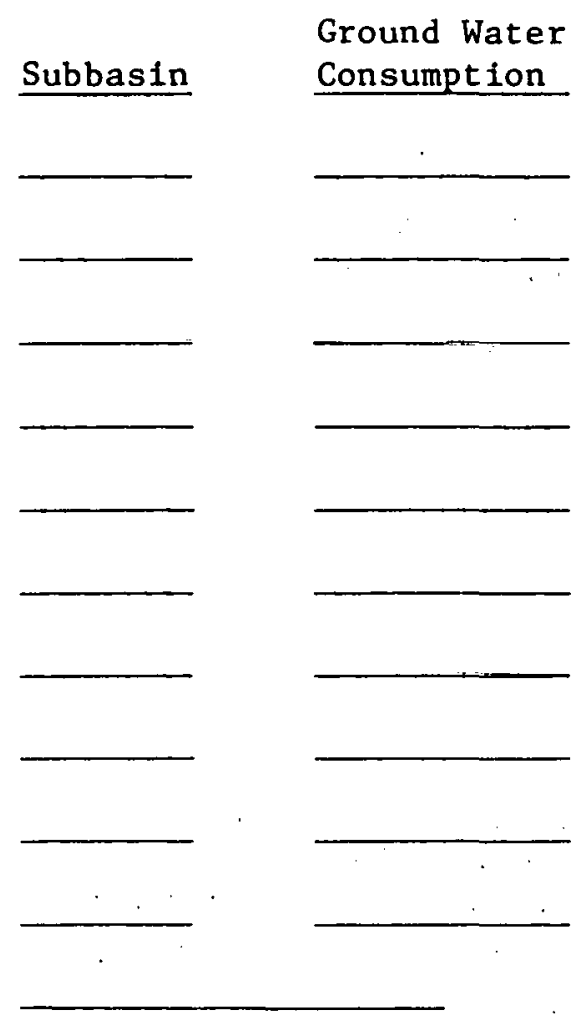

Snurce: Murray and Reeves, "Estimated Water Use in the United States in 1975" (1977). 
Table F-11

ENVIRONMENTAL WORKSHEET 4--

NONPOINT SOURCE POLLUTION

(Sheet E:nsion)

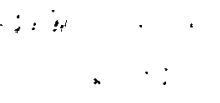

Sheet Erosion

Subbasin (tons/acre/year)
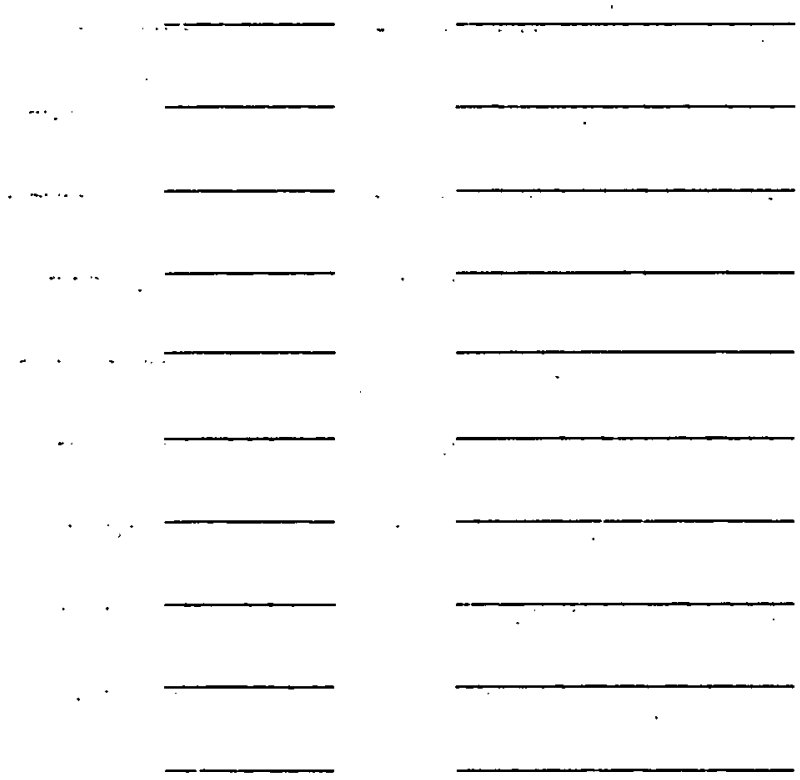

$\div$

Source: U.S. Water Resources

Council, The Second

National Water Assessment, Volume A-1

(April 1978) 
Table F-12

SOCIOECONOMIC WORKSHEET 1--INCREMENTAL LABOR REQUIREMENT

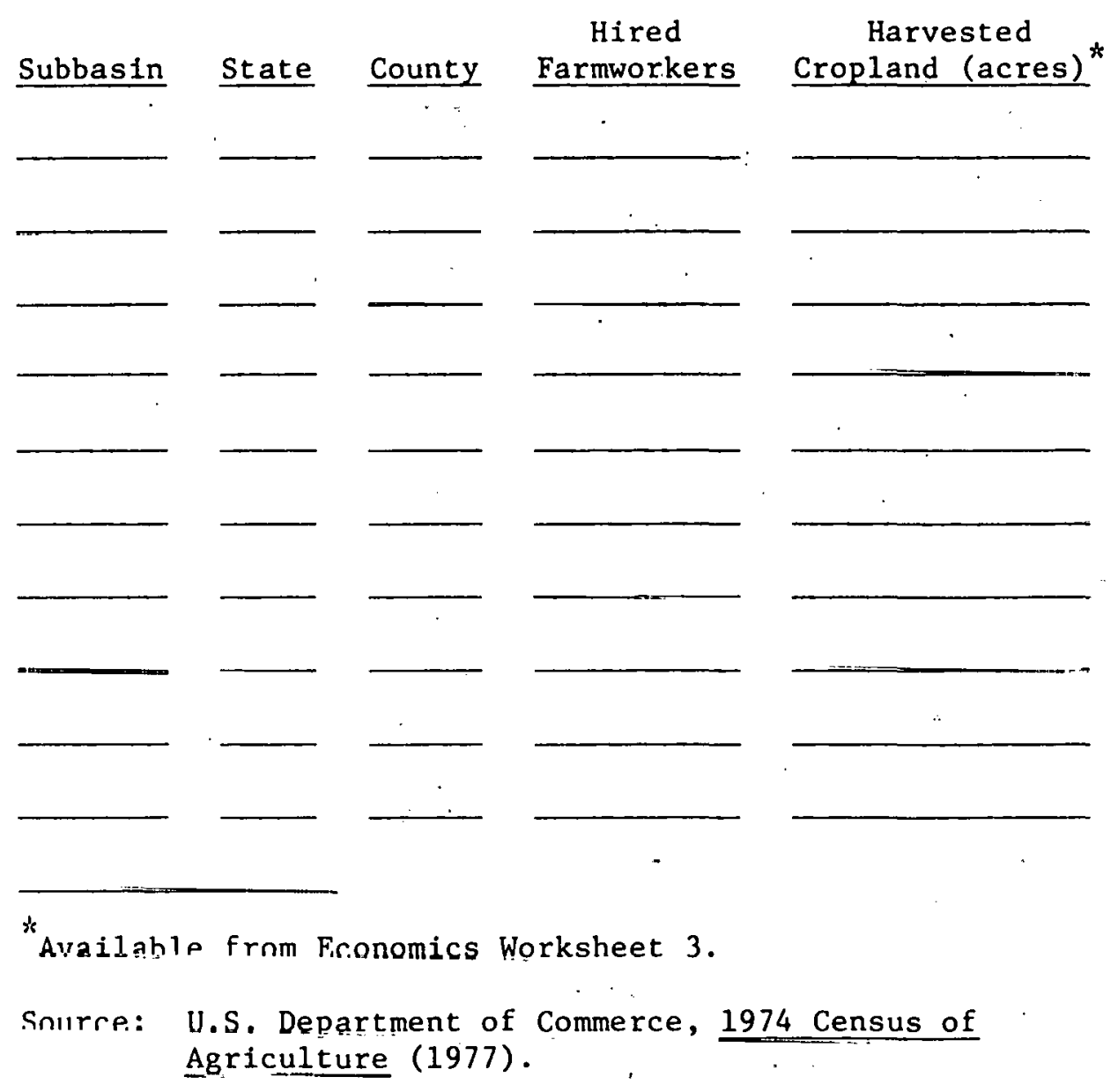


Table F-13

SOCIOECONOMIC WORKSHEET 2--LOCAL ECONOMY (Millions of Dollars)

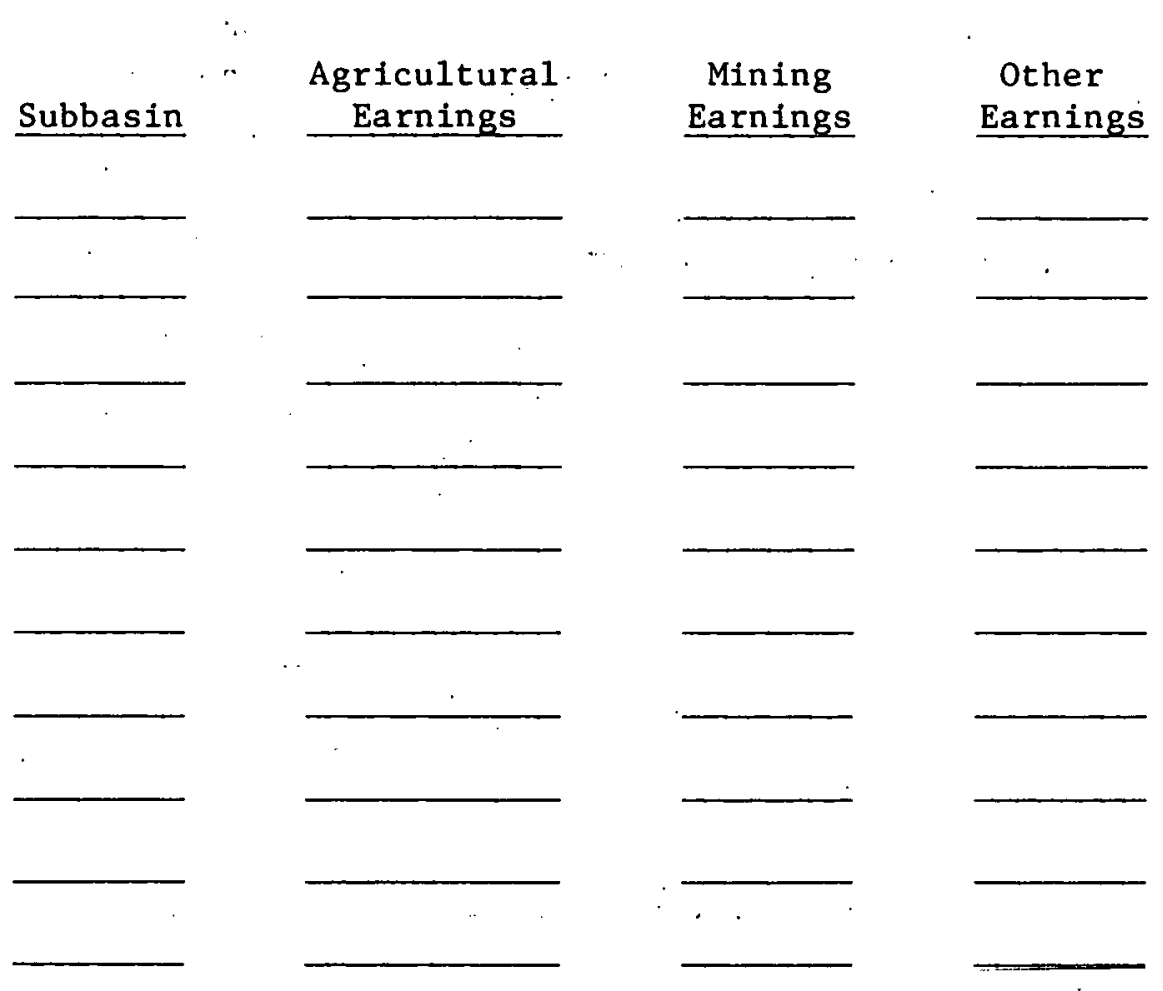

Source: U.S. Water Resources Council, The Second National Water Assessment; Volume 1

(April 1978). 
Table F-14

LEGAL/INSTITUTIONAL WORKSHEET 1--SIZE OF FARMS

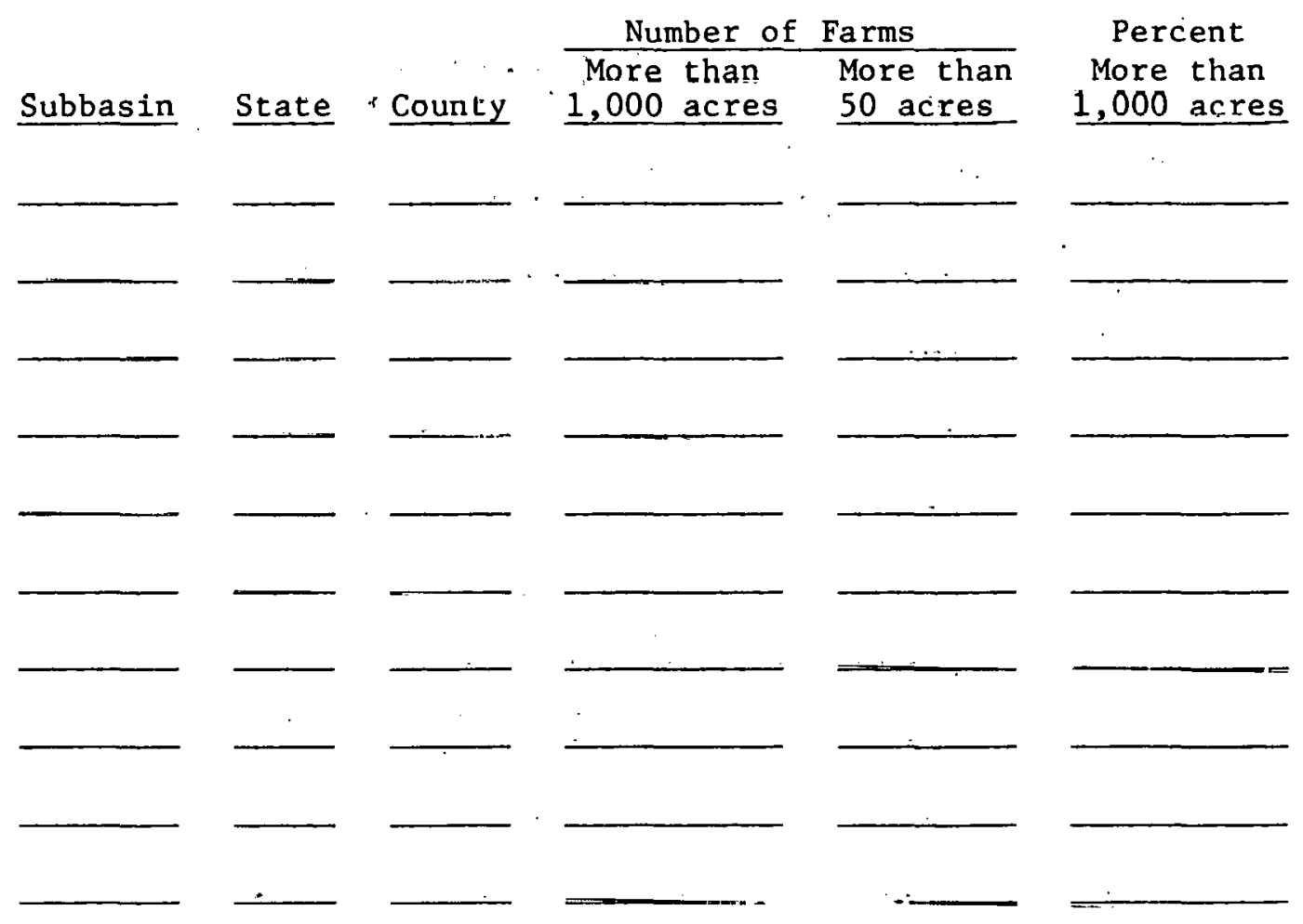

Source: U.S. Department of Commerce, 1974 Cẻnsus of Agriculture (1977). 
Table F-15

LEGAL/INSTITUTIONAL WORKSHEET 2-WATER QUALITY COMPACTS

Number of

Subbasin

Water. Quality Compacts
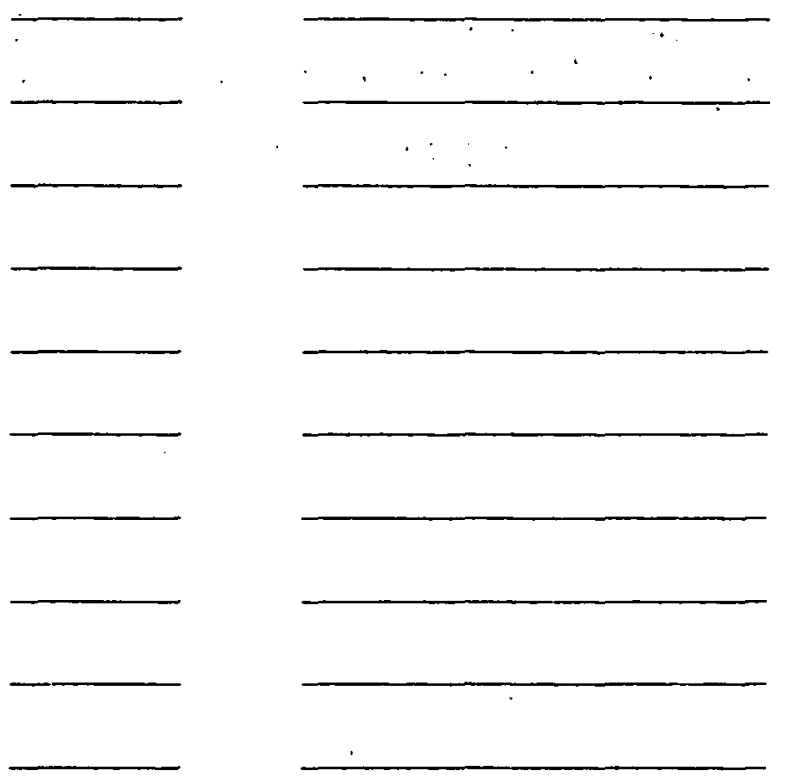

Source: U.S. Water Resources Council, Part 4 (April 1977); personal communications with state officials. 
Table F-16

LEGAL/INSTITUTIONAL WORKSHEET 3-WATER QUALITY STANDARDS

Subbasin

Percent of SLreailis Not Meeting Water Quality Standards
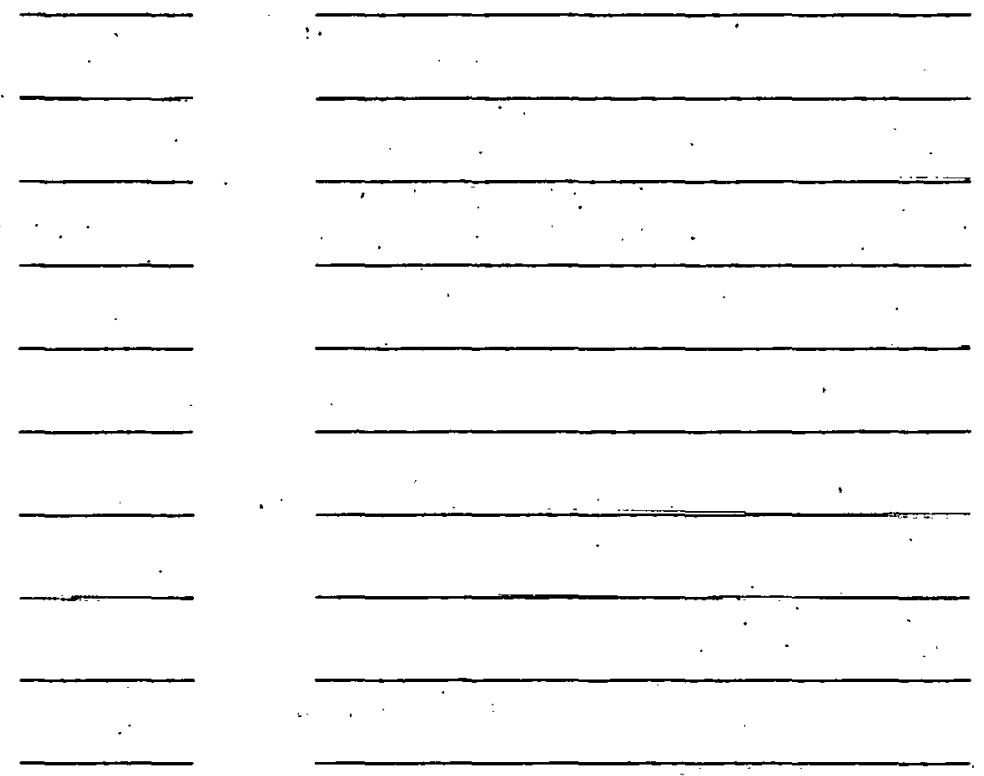

Source: U.S. Water Resources Council, The Second National Water Assessment, Volume A-1 (April 1978). 


\section{Table : F-17}

LEGAL/INSTITUTIONAL WORKSHEET 4--PERMITS

Minimum Number of Days Required To Obtain Permits Ground-Water Surface-Water

Subbasin Withdrawa1 Diversion Total

Subbasin
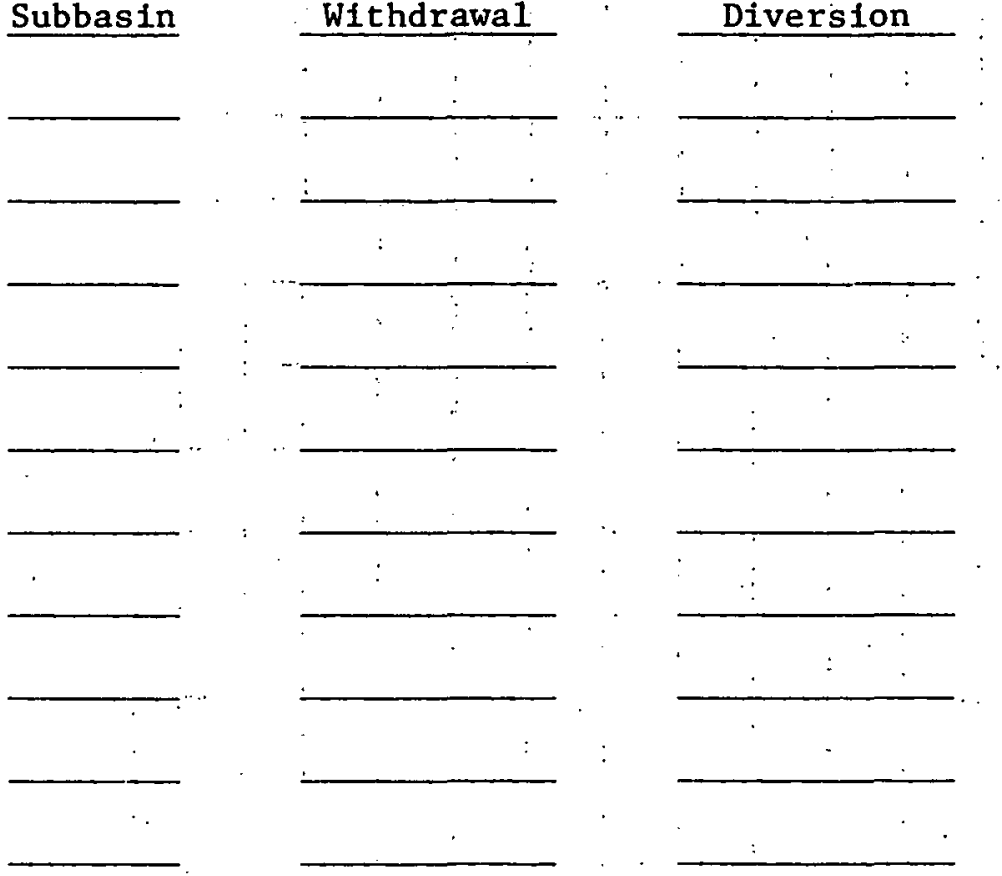

Days

Source: Personal communication with state officials. 
Table F-18

LEGAL/INSTITUTIONAL WORKSHEET 5--

SOLE-SOURCE AQUIFERS

(Square Miles)

Subbasin

Area of Sole-Source

Basin

Aquifer Within Basin

Area.
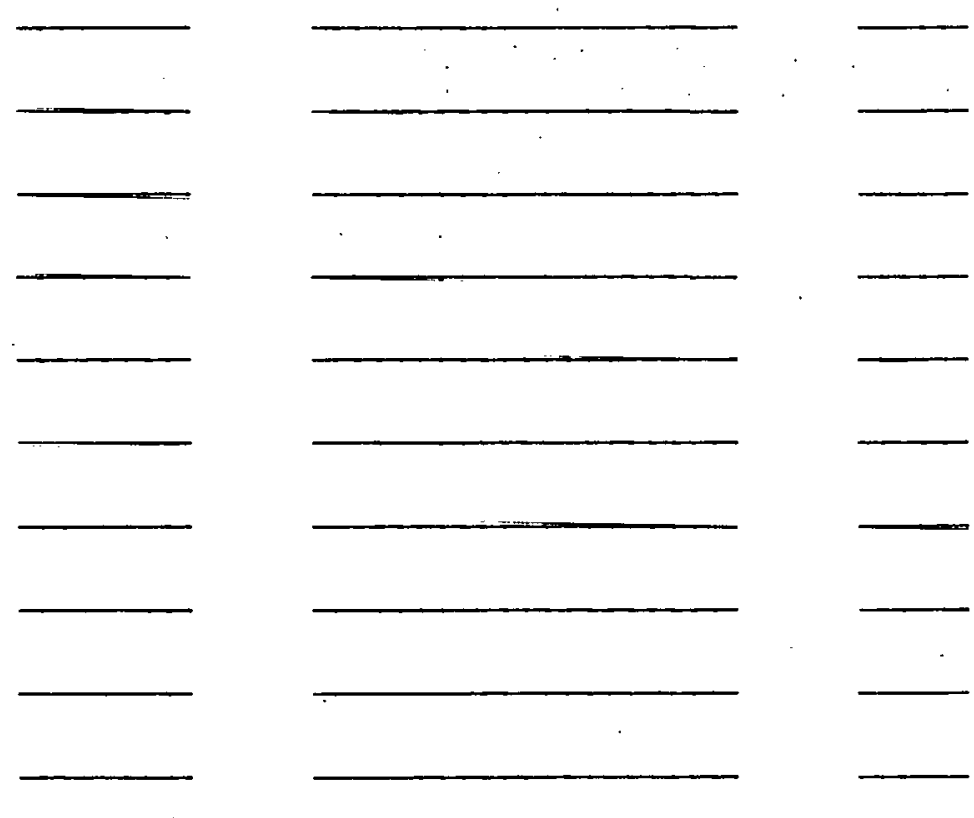

Source: Personal communication with U.S. Environmental Protection Agency, Office of Drinking Water.

\$U.S. GOVERNMENT PRINTING OFFICE: $1980-740-145537$ REGION NO. 4 